\title{
O IMPACTO DA CAPACITAÇÃO EM GESTÃO AMBIENTAL
}

\section{ARLINDO PHILIPPI JR}

Tese de livre-docência apresentada à

Faculdade de Saúde Pública da Universidade de São Paulo para obtenção do título de Livre Docente junto ao Departamento de Saúde Ambiental.

SÃO PAULO

2002 
Autorizo, exclusivamente para fins acadêmicos e científicos, a reprodução total ou parcial desta tese, por processo fotocopiador.

Arlindo Philippi Jr

01 de agosto de 2002

Philippi Jr., Arlindo

O Impacto da Capacitação em Gestão Ambiental. São Paulo: Universidade de São Paulo. Faculdade de Saúde Pública. Departamento de Saúde Ambiental, 2002. [Tese de Livre-Docência. Faculdade de Saúde Pública da USP]

240p.

I. Philippi Jr., Arlindo II. Universidade de São Paulo. Faculdade de Saúde Pública. Departamento de Saúde Ambiental. III. Título. 1. Gestão Ambiental 2.Capacitação 3. Meio Ambiente 
"Não existe nada mais difícil de se executar, nem mais duvidoso ou mais perigoso, que dar início a uma nova ordem das coisas. Pois o reformador tem como inimigos todos os que ganham com a ordem antiga $e$ conta apenas com defensores tímidos entre aqueles que ganham com a nova ordem. Parte dessa timidez vem do medo dos adversários, que têm a lei a seu favor; e parte vem da incredulidade da humanidade que não tem muita fé em qualquer coisa nova, até que a experimente". 


\section{Dedicatória}

Dedico esta tese ao Professor WALTER ENGRÁCIA DE OLIVEIRA, com emoção, pela sua contribuição serena à construção do espaço de atuação da área ambiental, representada pela sua luta para o claro entendimento da importância do saneamento ambiental da engenharia ambiental, e da área ambiental como um todo, no contexto da saúde. 


\section{AGRADECIMENTOS}

Ao apresentar este trabalho, quero registrar meus agradecimentos a todos aqueles que me ajudaram a levar a termo esta empreitada.

Representação da característica de atuação deste professor, o desenvolvimento da pesquisa que fundamentou esta tese reproduziu relações interinstitucionais envolvendo equipe de trabalho multidisciplinar, direcionada a uma prática interdisciplinar.

Desta forma, desejo expressar o meu reconhecimento a todos que direta ou indiretamente, ao longo da pesquisa, participaram, em variados graus de envolvimento desta realização, por meio de sua dedicação, competência, estímulo, carinho, amizade, cobrança, colo, apoio e incentivo, o que os torna tanto autores quanto eu. Assim sendo, manifesto o meu profundo respeito, admiração e gratidão a algumas destas muitas pessoas que contribuíram para este resultado, em nome de quem, cumprimento e agradeço a honra do convívio, o prazer da amizade, a satisfação do dever cumprido, aqueles que comigo compartilham a visão de futuro de um país economicamente desenvolvido, socialmente justo e ambientalmente equilibrado:

- Marcelo de Andrade Romero, amigo dedicado, incentivador, competente e companheiro na coordenação dos projetos da Gestão Ambiental;

- Maria Cecília Focesi Pelicioni, amiga e estimulante apoiadora de muitos projetos e atividades em Educação Ambiental;

- Pedro Caetano Sanches Mancuso, pelo convívio amigo de tantos anos e companheiro decisivo em tantas jornadas;

- Gilda Collet Bruna, professora vibrante e incentivadora, responsável maior pela existência dos Cursos de Gestão Ambiental na Universidade de São Paulo; 
- Márcia Faria Westphal, incentivadora na implantação das atividades de Educação Ambiental e de saúde e ambiente;

- Carlos do Celso do Amaral e Silva, companheiro de longos anos, direcionador e apoiador de muitas ações, contribuindo para a realização de Cursos na área Ambiental;

- Alaôr Caffé Alves, incentivador e decisivo parceiro na implantação dos cursos de Direito Ambiental na Universidade de São Paulo;

- Equipe técnica e administrativa do Núcleo de Informações em Saúde Ambiental da Universidade de São Paulo: Alessandro Cardoso, Carolina Marcondes de Campos; Elizabeth Marcondes, Futami Kato, Kátia Simões Parente, Mary Lobas de Castro, Patrícia de Vasconcelos Menezes Paz, Sérgio Barreto Tucunduva, Sérgio Ribeiro, Sidnei Garcia Canhedo Junior;

- Cíntia Philippi Salles, em especial, pela capacidade de trabalho, competência profissional e apoio em todas as horas;

- Tatiana Tucunduva Philippi, Daniella Mac-Dowell Leite de Castro, Silvia Deschamps e Patrícia Tischler, participantes dedicadas e ativas na pesquisa;

- Professores e funcionários do Departamento de Saúde Ambiental, participantes da minha trajetória no departamento;

- Alunos dos cursos de pós-graduação lato sensu especialização em Gestão Ambiental da Faculdade de Saúde Pública da Universidade de São Paulo, participantes ativos da pesquisa um agradecimento especial;

- Minha família, minha mulher Sonia Tucunduva Philippi, meus filhos Caio e Tatiana Tucunduva Philippi, pelo compartilhar em todas as horas da minha vida profissional e familiar.

A todos, todos mesmo, meu muito obrigado. 


\section{RESUMO}

Philippi Jr., Arlindo. O IMPACTO DA CAPACITAÇÃo EM GESTÃo AMBIENTAL. SÃO PAULO; 2002. [Tese de Livre-Docência apresentada à Faculdade de Saúde Pública da Universidade de São Paulo]

O controle da qualidade ambiental consta da Constituição Federal de 1988, como incumbência do poder público, juntamente com a promoção da conscientização social para a defesa do meio ambiente. A efetividade de tais dispositivos esbarra, porém, na carência de pessoal preparado para atuar e desenvolver projetos nesta área. A capacitação dos recursos humanos é um dos condicionantes para uma efetiva ação na área de Gestão Ambiental. Objetivo. Avaliar o impacto da atuação profissional multidisciplinar dos alunos capacitados pelos cursos de Pós Graduação lato sensu - Especialização em Gestão Ambiental da Faculdade de Saúde Pública e da Faculdade de Arquitetura e Urbanismo da Universidade de São Paulo. Metodologia. Do ponto de vista metodológico dividiu-se em duas etapas. A $1^{\text {a }}$ objetivou a identificação do perfil dos 408 alunos matriculados em 13 cursos realizados no período de 1995 a 2001, por meio de entrevistas, considerando os aspectos pessoais e profissionais: formação inicial, gênero, cidade e setor de atuação profissional, engajamento profissional na área ambiental, tempo de conclusão de curso. A $2^{\mathrm{a}}$ etapa teve três objetivos: conhecer a opinião atual dos alunos com relação a sua atuação no mercado profissional; avaliar as mudanças e os impactos ocorridos na vida profissional dos alunos após o curso de Gestão Ambiental e; comparar, analisar e discutir os dados obtidos nas duas etapas. Resultados: O perfil do aluno típico dos cursos CEGA de 1 a 13 indica 52\% do gênero masculino; 46\% engenheiros ou arquitetos; $69 \%$ atuam profissionalmente em São Paulo; 62\% atuam na área ambiental; 26\% desenvolveram trabalho final na área de resíduos; $68 \%$ trabalham no setor público; 80\% possuem entre 8 e 15 anos de formados. Os indicadores de impacto na atuação profissional dos respectivos cursos foram: $77 \%$ dos 
alunos mudaram a forma de pensar; 89\% dos alunos alteraram positivamente a forma de atuar nos locais de trabalho; 55\% dos alunos tiveram ascensão profissional após a capacitação em Gestão Ambiental; $75 \%$ dos alunos atuaram ou atuam como agentes de capacitação em seus próprios locais de trabalho. Conclusões: A avaliação da atuação dos alunos em seus locais de trabalho, a avaliação de suas ações regionais, bem como o resultado de todo o esforço empregado por eles em um ano de atividade do curso; permitiram redirecionar parte do projeto de capacitação em termos de disciplinas e conteúdos, tendo em vista as características e especificidades dos alunos. Possibilitou também conhecer mais profundamente os alunos, as suas origens e os seus potenciais para atuações futuras.

Descritores: Gestão Ambiental; Capacitação; Meio Ambiente. 


\section{ABSTRACT}

Philippi Jr., Arlindo. The impact of acquiring knowledge on environmental management. São Paulo; 2002. [Livre Docência Thesis presented to Faculdade de Saúde Pública (School of Public Health) of the University of São Paulo]

The environmental quality control and the promotion of social awareness for environmental protection are a duty for governmental authorities as established by the Federal Constitution of 1988. The effectiveness of these provisions come up against the lack of prepared people to act and develop projects in this area. Raising human resources is one of the conditionings for an effective action in the environmental management. Objective: To evaluate the impact of the multidisciplinary professional performance of the students who acquired knowledge on environmental management through the Lato Sensu Postgraduation Courses in Environmental Management at the Faculdade de Saúde Pública (School of Public Health) and the Faculdade de Arquitetura e Urbanismo (School of Architecture and Urbanism) of the University of São Paulo. Methods: There were two different stages on this survey. The first one identified the profile of the 408 students registered in 13 environmental management courses, which took place from 1995 to 2001, through interviews considering personal and professional aspects: background; undergraduation; professional field; professional commitment to the environmental area; extension of the course. The second stage had three objectives: get to know the current opinion of the students regarding their professional fields; to evaluate the changes and impacts on their careers after the environmental management course; and to compare, analyze and discuss the obtained data from these two different stages of the survey. Results: The profile of the regular student of the Courses 1 to 13 indicates that 52\% are male; $46 \%$ are engineers and architects; 69\% are working in São Paulo; 62\% work in the 
environmental area; $26 \%$ has developed work in the solid waste area; $68 \%$ work at public service; $80 \%$ have graduated from 8 to 15 years ago. The indicators of the impact of those courses at the professional field were: $77 \%$ of the ex-students have changed their way of thinking; $89 \%$ of the exstudents have positively changed their behavior at work; $55 \%$ of the exstudents had professional rise after acquiring knowledge on environmental management; $75 \%$ of the ex-students act as agents of knowledge on environmental management in their works. Conclusions: The evaluation of ex-students at their workplaces, the evaluation of their local actions, as well as the result of all efforts applied by them during a one year period of activities span, allowed to re-direct part of the project of acquiring knowledge on environmental management in terms of subjects and contents, taking into account the characteristics of the students. It also allowed to know better the students, their origin and their potential for future performances.

Descriptors: Environmental Management; Acquiring knowledge; Environment. 
DEDICATÓRIA

AGRADECIMENTOS

RESUMO

ABSTRACT

ÍNDICE

\section{CAPÍTULO 1 - INTRODUÇÃO}

1.1 Gestão ambiental: a guisa de introdução, p.1.1

1.2 Gestão ambiental: marcos históricos, p.1.11

1.3 Gestão ambiental: marcos teóricos, p. 1.21

1.4 Gestão e globalização, p. 1.31

1.5 A capacitação ambiental de recursos humanos, p.1.40

\section{CAPÍTULO 2 - A ESPECIALIZAÇÃO EM GESTÃO AMBIENTAL}

2.1 A Faculdade de Saúde Pública, p. 2.1

2.2 A Faculdade de Saúde Pública e a Pós-Graduação Lato-Sensu, p. 2.3

2.3 Os Núcleos de Apoio às Atividades de Cultura e Extensão (NACE) como agentes de capacitação, p. 2.5

2.3.1 O Núcleo de Informações em Saúde Ambiental da USP, p.2.6

2.4 Os Cursos de Pós-Graduação Lato-Sensu - Especialização em Gestão Ambiental, p.2.9

\subsubsection{Antecedentes, p.2.9}

2.4.2 Pressupostos assumidos no desenvolvimento e aprovação dos cursos, p.2.11

2.4.3 O processo de seleção e a multidisciplinaridade, $\boldsymbol{p . 2 . 1 3}$

2.4.4 O processo de avaliação na formação de recursos humanos, p.2.15 
2.4.5 O processo de avaliação continuada, $\boldsymbol{p . 2 . 1 8}$

2.4.6 A estrutura curricular atual, p. 2.20

2.5 Justicativa da escolha do tema, $\boldsymbol{p . 2 . 2 2}$

2.6 Hipótese e Objetivos, p.2.24

2.6.1 Objetivo Geral, p.2.25

2.6.2 Objetivos específicos, $\boldsymbol{p} . \mathbf{2 . 2 5}$

\section{CAPÍTULO 3 - METODOLOGIA}

3.1 Considerações preliminares, $\boldsymbol{p}$. 3.1

$3.21^{\text {a }}$. Etapa da pesquisa, $\boldsymbol{p} . \mathbf{3 . 1}$

$3.32^{\mathrm{a}}$. Etapa da pesquisa, $\boldsymbol{p} . \mathbf{3 . 2}$

3.3.1 Universo da pesquisa e amostra representativa, p. $\mathbf{3 . 2}$

3.3.2 Método adotado no levantamento de dados, p. 3.4

3.3.3 Elaboração do pré-teste, p. $\mathbf{3 . 5}$

3.3.4 A aplicação do pré-teste, análise e a elaboração do questionário definitivo, p. 3.6

3.3.5 Aplicação do roteiro de entrevistas, $\boldsymbol{p}$. $\mathbf{3 . 7}$

3.3.6 Análise dos dados, p.3.8

3.4 Resultados e discussão, $\boldsymbol{p} . \mathbf{3 . 8}$

3.5 Conclusões, p.3.9

\section{CAPÍTULO 4 - RESULTADOS E DISCUSSÃO}

4.1 Considerações preliminares, $\boldsymbol{p} . \mathbf{4 . 1}$

4.2 Análise dos resultados $-1^{\mathrm{a}}$. Etapa da pesquisa, p. 4.1

4.2.1 Produção discente por área do conhecimento p. 4.28

4.2.2 Características do corpo discente para os cursos: CEGA 1 CEGA 13, p. 4.35

4.3 Resultados - $2^{\mathrm{a}}$. Etapa da pesquisa - Entrevistas, p. 4.42 


\section{CAPÍTULO 5 - CONCLUSÕES}

5.1 Conclusões da $1^{a}$. Etapa da pesquisa, p. 5.1

5.2 Conclusões da $2^{\mathrm{a}}$. Etapa da pesquisa, p. $\mathbf{5 . 3}$

5.2.1 Atuação na área ambiental, p. $\mathbf{5 . 3}$

5.2.2 Setores de atuação, $\boldsymbol{p} \mathbf{5 . 4}$

5.2.3 Indicadores de impacto na atuação profissional, p. $\mathbf{5 . 5}$

5.3 Objetivos e hipóteses, $\boldsymbol{p} . \mathbf{5 . 7}$

CAPÍTULO 6 - CONSIDERAÇÕES FINAIS, p. 6.1

\section{CAPÍTULO 7 - REFERÊNCIAS, p. 7.1}

\section{PÓS-TEXTO}

Bibliografia complementar, $\boldsymbol{p .} 1$

Glossário, p.10

Siglas e abreviaturas, $\boldsymbol{p} .23$

Índice remissivo - figuras, $\boldsymbol{p} .27$

Índice remissivo - tabelas, p. 29

Índice remissivo - quadros, $\boldsymbol{p} .29$

\section{ANEXOS}

Anexo 1 - Estrutura curricular e conteúdo programático dos cursos CEGAvigente, $\boldsymbol{p}$. A.1

Anexo 2 - Modelo de questionário de avaliação semestral do curso, p. A.28

Anexo 3 - Modelo de questionário de avaliação de disciplina, p. A.31

Anexo 4 - Planilha com os resultados da tabulação de dados de disciplina do curso, $\boldsymbol{p}$. $\boldsymbol{A} .34$

Anexo 5 - Roteiro de entrevista final aplicado nesta pesquisa, p. A.36

Anexo 6 - Dados cadastrais dos alunos, p.A.40

Anexo 7 - Opções temáticas das monografias, p. A.54 


\section{CAPÍTULO 1 - INTRODUÇÃO}

\subsection{Gestão ambiental: a guisa de introdução}

O campo da gestão ambiental é muito extenso. Essa extensão se explica porque o tema meio ambiente precisa ser entendido em sua complexidade como um conjunto de fatores que constituem o todo. Ocorre que a extensão dos problemas ambientais costuma não ser reconhecida como decorrência das diversas facetas que compõem as questões ambientais, como se fossem compartimentos independentes, cuja importância e emergência depende do problema a ser resolvido.

Assim é que, em certas comunidades, é dada prioridade para alguns desses compartimentos por parte do poder público. Como exemplo, a preocupação mundial com o clima, em função do chamado efeito estufa, está associada à emissão de gases, em especial o dióxido de carbono $\left(\mathrm{CO}_{2}\right)$, o qual advém da queima de combustíveis fósseis. Este efeito parece levar a um aquecimento global, resultante do uso de tecnologias associadas a comportamentos e necessidades sociais relacionados com um estilo de vida ainda altamente dependente do consumo energético baseado na combustão. A busca de soluções para esta problemática passa, necessariamente, pela revisão de modelos de desenvolvimento, abrangendo questões tecnológicas, industriais, econômicas, culturais, entre outras, todas associadas ao estilo de vida predatória das sociedades atuais.

Como conseqüência, o tratamento multidisciplinar é um requisito básico para o enfrentamento de problemas como este, o que exige o trabalho de profissionais de diferentes formações, atuando de forma articulada e envolvendo a sociedade. Em circunstâncias como estas, em que toda a sociedade vê-se afetada, pode ser necessária a discussão em termos planetários, como vem ocorrendo em várias ocasiões, a exemplo da 
conferência de Kyoto, no Japão, em 1997, que debateu internacionalmente um esboço de acordo sobre o clima, voltado para a questão do aquecimento global.

Assim é que os temas ambientais ocupam um espaço respeitável entre as grandes preocupações contemporâneas. Permitem estruturar uma espécie de radiografia da realidade, que, face aos problemas emergentes, está a exigir uma tomada de consciência e, principalmente, uma solução imediata. A manifestação mais sensível e eficiente, mas nem sempre eficaz, dessa preocupação é o surgimento de uma literatura ambiental estimulada por eventos que vêm discutindo aspectos variados do desenvolvimento, buscando o controle e a melhoria da qualidade ambiental. Surgem e aprofundam assim conhecimentos técnicos e científicos em busca de fórmulas capazes de encaminhar a solução de problemas ambientais que afligem a humanidade, devendo contribuir para gerar um processo adequado ao desenvolvimento social, econômico e ambiental.

Em termos práticos, os poderes públicos estão diante de necessidades imediatas. Por exemplo, prover o abastecimento de água potável à população vem tornando-se dispendioso, pois em muitos casos já não há disponibilidade de água com qualidade. Uma das principais fontes de poluição dessas águas tem sido os dejetos humanos e demais rejeitos da comunidade que, por vezes, poluem mais que as atividades industriais, ainda que a população não tenha se dado conta desse fato.

A água tem se mostrado um bem escasso frente à concentração populacional em regiões metropolitanas do país. Há certas evidências de que o Brasil vive um desenvolvimento insustentável, devido a uma escassez qualitativa e quantitativa de água. É fato que a Região Metropolitana de São Paulo importa água de outras bacias hidrográficas. Muitos pensam que é um problema local, porém o interesse é regional. A 
Organização das Nações Unidas (ONU) tem afirmado que a falta ou a contaminação das águas ou ambas, vão afetar praticamente todos os habitantes do planeta nos próximos 50 anos (ONU 1991).

Problemas como o apontado acima indicam a necessidade de contar com literatura dirigida a aspectos setoriais que, entretanto, não podem prescindir de conhecimentos voltados para enfoques mais amplos que reúnam a reflexão em termos globais. Mesmo a existência de textos e produção científica sobre a matéria exige revisão e atualização constantes que permitam o avanço do conhecimento.

Necessidades emergentes e problemas crônicos acabam por demandar estudos relacionados com formas de gestão, ainda que voltados a temas setoriais, que estão a exigir uma compreensão e ação integrada. O mesmo acontece na esfera do governo quando se focalizam certas legislações de caráter ambiental, com diretrizes, regulamentos e formas de controle; muitas vezes este almejado controle não é obtido. A Lei de Proteção dos Mananciais da Região Metropolitana de São Paulo, de 1975, por exemplo, por ser muito restritiva, induziu a geração de efeitos contrários aos seus objetivos e acabou contribuindo para formas de ocupação ilegal, organizadas por grupos da sociedade. Essa urbanização perversa é, hoje, uma das maiores responsáveis pela poluição e degradação das represas Guarapiranga e Billings, devido ao desmatamento irresponsável, à erosão e conseqüente assoreamento, ao lançamento de esgotos domésticos e de lixo em córregos, nas vertentes dos reservatórios e mesmo nas próprias represas. Estes fatos refletem uma abordagem excludente que não previu a possibilidade de existir outras formas de ocupação com controle ambiental. Esta postura leva a repensar a situação e buscar novas soluções.

A visão aqui explicitada é de uma gestão ambiental com abordagem integrada, que procura abranger simultaneamente questões que interferem 
no ambiente, natural ou construído, bem como as interações envolvendo diferentes sistemas, como, por exemplo, o sistema de abastecimento de água e suas relações com os sistemas de esgotamento sanitário e de recursos hídricos. Da mesma forma a gestão ambiental deve contemplar a gestão compartilhada das funções públicas de interesse comum relacionadas aos municípios e respectivas regiões metropolitanas ou conurbadas, quando houverem (CAFFÉ ALVES 1998).

O método cartesiano de conhecimento mostra que é fundamental dividir o todo em partes para a melhor compreensão de cada uma das partes, embora o comportamento do todo seja distinto daquele das partes, mostrando a importância de se construir uma visão integrada do todo, ou seja, uma visão holística. Sem dúvida, a contribuição de Descartes é de inegável valor quando aplicada às múltiplas facetas da temática ambiental. Aliás, cabe dizer que essa temática historicamente sempre se manifestou através de questões setoriais divorciadas de uma visão integrada e abrangente, ou seja, que contemple a sua integração abrangente.

Devido, entretanto, à complexidade do universo ambiental, o método cartesiano - enfatizando as partes - embute o risco de perder a visão do todo. Ora, sabendo que quando se trata de meio ambiente, por mais importante que seja o conhecimento das partes, todas elas, absolutamente todas, mantêm um vínculo de relacionamento vital entre si; daí a importância da visão sistêmica que deve orientar o estudo das questões ambientais do planeta Terra, seja do Brasil, seja dos Estados, seja das Regiões Metropolitanas, seja das cidades. Essa visão sistêmica mostra muitas inter-relações entre as diferentes escalas aqui mencionadas, desde partes desérticas até outras densamente ocupadas, ou ainda, áreas de florestas que têm sofrido modificações, por meio de invasões de moradia ou desmatamento para criação de gado. 
O fato de as diversas áreas que compõem o complexo ambiental estarem estreitamente correlacionadas, fornece as bases para dar início ao estabelecimento de propostas de gestão ambiental que abranjam as complexidades do meio ambiente, fundamentadas numa integração físicoterritorial, social, política, econômica e cultural. Vem a propósito os pensamentos representados pelos novos conceitos no campo da física, que possibilitaram uma profunda mudança na visão do mundo, isto é, uma visão que passou de uma concepção mecanicista, de Descartes e Newton, para uma visão holística e ecológica da concepção do universo, a partir do conhecimento da estrutura atômica. Deste ponto de partida, a percepção é diferente do mundo cartesiano. A visão global leva a interligar os fenômenos biológicos, psicológicos, sociais e ambientais de maneira interdependente. Abandona a visão cartesiana e passa a ser tratada numa perspectiva ecológica, ou seja, uma nova visão de realidade, baseada em pensamentos, percepções e valores (ONU 1990).

A abordagem da gestão ambiental está a exigir ainda dois olhares. $\mathrm{O}$ primeiro, refere-se à compreensão do significado da expressão meio ambiente, abrangendo, tanto o meio natural, como o construído, isto é, aquele alterado pela ação do homem. Este, identificado com o espaço urbano ou o agrícola; aquele, com a natureza em seu estado primitivo ou recomposto. O segundo, refere-se à característica abrangente da gestão ambiental que envolve a saúde pública e o planejamento territorial (CAMPOS 2002).

Deve-se, entretanto, tomar cuidado com uma espécie de reducionismo que limita o campo do conhecimento ambiental apenas àqueles ambientes que se identificam com o estado natural do planeta, onde é dada uma ênfase à fauna e à flora, como objetos de preservação ou de conservação. Há que se ampliar reflexões e estudos sobre o espaço urbano em seu sentido ecológico. Afinal, a cidade é por excelência o ambiente do homem, no dizer de COIMBRA 1985. É nesse ambiente - ecossistema construído - que são 
encontrados os mais graves indicadores de desequilíbrio. Este, provocado pelo estágio de degradação dos elementos da natureza está a exigir urgente atuação da gestão ambiental.

As diversas situações urbanas e ambientais existentes, exigem destaque para a busca de inovações nas administrações locais que podem ser levadas a pensar de maneira distinta do planejamento urbano tradicional, criando espaço para uma nova mentalidade na gestão urbana e ambiental (BRUNA 2002).

A promoção da qualidade de vida, escopo último da gestão ambiental, tem fortes vínculos com a saúde pública e o planejamento territorial. Tema de inquietações para vários segmentos da comunidade, são os problemas da sociedade industrial e tecnológica, responsáveis por vastos estragos que esse tipo de progresso vem espalhando pelo mundo natural. Inquietações para o homem comum com as condições de moradia, alimentação e trabalho. Inquietações para o cidadão cuja estabilidade econômica depende das incertezas que enfrenta em seu dia-a-dia, contribuindo até inconscientemente para aumentar a poluição de seu ambiente.

Trata-se de equacionar os problemas da convivência humana com os seus impactos negativos sobre a saúde pública e o meio ambiente. Daí a importância da gestão ambiental. O significado etimológico dos dois vocábulos - gestão e ambiental - tem suas raízes na língua latina. Gestão originou-se de gestioni, que exprime o ato de gerir. Gerir é um verbo inusitado no linguajar de cada dia, cujo significado é ter gerência sobre, administrar, reger, dirigir. Desses sinônimos, o mais usado é o substantivo derivado: gestão, ou seja, o ato de dirigir, de administrar. O vocábulo ambiental, também tem origem na língua-mãe latina. É o adjetivo aplicado para referir-se às coisas do ambiente; tanto ambiente construído, quanto ambiente natural. 
A palavra ambiente, por sua vez, foi formada de outros dois termos latinos: a preposição amb (ao redor de, à volta de) e o verbo ire (ir). A soma dos dois resultou ambire, cujo particípio presente, ainda em latim, é ambiens, ambientis. Em conclusão, é fácil entender que ambiente é tudo o que está ao redor (COIMBRA 1985). Indo um pouco mais longe no conceito etimológico, ambiental é o adjetivo que qualifica as coisas e os elementos que estão à volta de um determinado ser. Cabe destacar ainda que os termos meio, ambiente e meio ambiente são freqüentemente usados como sinônimos.

Com base nesses conceitos, gestão ambiental é o ato de gerir o ambiente, isto é, o ato de administrar, dirigir ou reger as partes constitutivas do meio ambiente. Para entender a abrangência e o alcance dessa definição, destaca-se que gestão ambiental é o ato de administrar, de dirigir ou reger os ecossistemas naturais e sociais em que se insere o homem, individual e socialmente, num processo de interação entre as atividades que exerce, buscando a preservação dos recursos naturais e das características essenciais do entorno, de acordo com padrões de qualidade. $\mathrm{O}$ objetivo último é estabelecer, recuperar ou manter o equilíbrio entre natureza e homem (COIMBRA 1985).

Se o vocábulo gestão é entendido como sendo o ato de gerir, o conceito de ato conduz à idéia de que a administração do meio ambiente só acontece quando há de fato, o equilíbrio ambiental, quando se dá a harmonia entre o homem e a natureza, o que significa que a harmonia entre homem e seu meio está acontecendo, ou a caminho de acontecer.

Uma analogia com alguns conceitos filosóficos ajuda a compreender melhor os aspectos teóricos e práticos da gestão ambiental. Na Metafísica, o estudante aprofunda a noção de potencial e de ação em relação à 
existência e ao conhecimento dos seres; como se comportam na realidade, verificando pela observação, pela experiência e consciência que as coisas mudam; constata que onde há mudança, há passagem.

Chega-se então à conclusão de que as coisas não estão fechadas ou lacradas. Têm dentro de si o poder ser outra coisa ou ser outra maneira de ser. Esse poder ser é algo real, embora apenas poder ser não signifique nada, pois, na verdade, não existe. É apenas um potencial.

A ação, por sua vez, será então para os filósofos a realização do poder ser, a concretização do potencial, do que está latente nas coisas. Mas esse potencial pode acabar não se realizando. A cidade, por exemplo, está em contínua mudança e apresenta inúmeras potencialidades, que só se realizarão na medida em que houver ação. Com o que se costuma chamar gestão ambiental pode ocorrer o mesmo fenômeno da não-realização: gestão ambiental potencial e gestão ambiental ação.

O que se entende, pois, por gestão ambiental enquanto potencial? É, com certeza a existência de leis, normas, decretos, regulamentos, escritos, dirigidos e determinados com o objetivo de solucionar as questões do ambiente. Sua mera existência, por si só, não constitui gestão propriamente dita. Pra que realmente aconteça e se concretize a gestão ambiental, é preciso que aquela potencialidade se transforme em ação concreta, deixando de ser apenas leis e normas, tornando-se gestos transformadores resultantes da aplicação daqueles instrumentos. Em suma: concretizando a mudança do poder ser real para o ser real.

O mesmo pode-se afirmar em relação ao que acontece no campo da administração como hoje é praticada. Com certeza os métodos modernos, que têm como base os distintos conceitos de eficiência e eficácia, se apóiam na lição filosófica dos conceitos teóricos de potencial e ação. 
Portanto, gestão ambiental eficiente corresponde à existência e utilização de um conjunto de instrumentos. Só será eficaz, porém, quando esse conjunto se transformar em ações que se traduzam em problemas resolvidos.

Enquanto a sociedade se desenvolve apenas na direção meramente econômica, privilegiando uns em detrimento da maioria, não se pode dizer que exista gestão ambiental, mesmo que em nome desta se elaborem leis e decretos, se produzam normas e estratégias, ou se estabeleçam diretrizes e políticas. Na verdade, nada acontece automaticamente apenas com instrumentos de controle ambiental ou com declaração de princípios. Mas, os esforços que partem das autoridades governamentais ou dos técnicos da área têm algum valor? Por certo que têm, na medida em que produzam os efeitos pretendidos pelos seus autores.

Essas considerações vêm à baila porque é comum valorizar esse arsenal de regras, leis e normas colocando-lhes o rótulo de gestão ambiental. E o que é mais grave, a sociedade parece satisfeita com sua existência. $\mathrm{Na}$ prática, o ambiente a cada dia fica mais deteriorado e fora do controle. Em outras palavras, constata-se a existência de uma gestão ambiental, mas verifica-se apenas alguma melhora no ambiente se for levado em conta o potencial do arsenal mencionado.

A ação reguladora dos governos, bem como o cumprimento da legislação brasileira, têm sido praticada com dificuldade ou têm-se voltado, muitas vezes, para o atendimento de pequenos grupos hegemônicos, sem a necessária atenção à melhoria das condições de vida da população em geral e principalmente, das camadas menos favorecidas (COPASAD 1995).

O direito ambiental, entretanto, vem colocando à disposição dos cidadãos outros mecanismos de defesa de interesses coletivos ou difusos tais como 
a ação civil pública, o inquérito civil, a obrigatoriedade dos estudos de impacto ambiental e as procuradorias de meio ambiente, entre outros, que vêm desempenhando seu papel como poderosos instrumentos de gestão.

O cumprimento efetivo do Estatuto da Cidade, a reforma do sistema tributário, a articulação das Agendas 21 nacional, regionais e locais, certamente levarão as cidades a se tornarem mais saudáveis, igualitárias e sustentáveis. Para isso torna-se necessário que os movimentos sociais organizados assumam maior controle social na defesa do bem comum e exerçam seu direito de reivindicar.

O direito à uma cidade saudável tem que ser socializado, o que implica em exercício do direito à cidadania, isto é, na participação democrática de seus habitantes na gestão de seu destino, numa gestão compartilhada onde as prioridades são definidas pelo critério de atendimento ao bem comum e pelo uso socialmente justo e ecologicamente equilibrado do território.

A concepção de um crescimento urbano equilibrado deve basear-se também na integração de políticas setoriais e em uma nova cultura de gestão, a gestão pela defesa da vida e do meio ambiente (PELICIONI 2002).

Este tipo de gestão de uma cidade, de um território, de uma região, de um país, demanda esforços que venham assegurar sustentabilidade e, portanto, depende de um novo modelo político, mais ético, mais justo e mais solidário.

Esta é a gestão ambiental que se propõe, entendendo que somente desta maneira é que haverá condições para o avanço da sociedade como um todo, avanço este que depende cada vez mais da interação entre cidadania, meio ambiente e recursos humanos capacitados para o desafio. 


\subsection{Gestão Ambiental: marcos históricos}

Para focalizar a Gestão Ambiental é preciso voltar-se aos estudos ecológicos incluindo ambientes construídos e naturais, destacando-se a compreensão dos assentamentos humanos e nestes, os processos de produção e uso do solo. Assim, passa a ser importante analisar e interpretar as reações dos seres humanos como usuários desses ambientes, suas necessidades, atitudes e valores que demandam distintos tipos de intervenção com diferentes impactos, conforme se pode interpretar, ao longo do tempo.

As diferentes formas de avaliação ambiental e de análise sobre as relações entre o ambiente e o comportamento de seus habitantes podem ser elementos-chave para se entender essa questão, buscando verificar aspectos específicos dessas ações e reações ambientais e seus diferentes resultados sobre o meio físico, conforme os estímulos emitidos e recebidos (ORNSTEIN, BRUNA, ROMÉRO,1995).

Em termos históricos, essa avaliação ecológica apresentou nuances específicas relativas às necessidades de cada período. Acompanhando a revolução industrial, não há dúvidas, entretanto, que a urbanização cresceu rapidamente e as áreas urbanas e edifícios passaram a ser os receptáculos dessa concentração humana. Estudiosos e especialistas vêm avaliando o fenômeno, ainda que com interpretações distintas, mas, principalmente dirigidos pela necessidade de analisar e prever as possibilidades de desenvolvimento futuro, em um planeta cujas condições naturais vêm sendo continuamente agredidas e modificadas, consciente ou inconscientemente. Discutindo a questão, pode-se iniciar tomando-se a década de 1970 como um marco de referência. Os estímulos à substituição da importação por produtos nacionais, aliados ao desenvolvimento 
industrial do país, são um marco histórico das modificações no uso e ocupação do solo, que redundaram na conformação das regiões metropolitanas do Rio de Janeiro e de São Paulo, inicialmente com características nacionais e as demais como metrópoles regionais: Fortaleza, Salvador e Porto Alegre.

A desconcentração urbana da década de 1970 levou a uma conformação territorial que se pode dizer típica desta época. Antes a ocupação ocorria preferencialmente ao longo da costa Atlântica e ao redor das principais capitais de estado não litorâneas. Destacavam-se também os principais adensamentos metropolitanos. O censo de 1970 mostrou que na Região Metropolitana de São Paulo já havia sido iniciada uma desconcentração industrial, ainda mais acentuada nos anos seguintes.

Essa desconcentração industrial, fruto de políticas públicas, especialmente dos Planos Nacionais de Desenvolvimento, os chamandos PNDs, foi dirigida durante toda a década, por vários projetos especiais como os corredores de exportação, as zonas francas de produção industrial, a implantação das rodovias Transamazônica e Belém-Brasília, o programa nacional de cidades e das capitais de porte médio.

Os municípios, para poderem receber recursos financeiros dos vários programas em implantação pelo poder público federal, foram induzidos pelo próprio nível federal, ao desenvolvimento e elaboração de seus planos diretores municipais. Os recursos foram para investimentos em setores como habitação, infra-estrutura e transportes e oriundos do Plano Nacional de Saneamento e do Plano Nacional de Habitação, administrados pelo Serviço de Patrimônio Histórico-SERPHAU.

Os assentamentos humanos passaram então a ser alvo do planejamento. $\mathrm{O}$ $I^{\circ}$ Plano Nacional de Desenvolvimento-PND trazia uma menção ao 
ambiente urbano, mas os $I^{\circ}$ e $I^{\circ}$ PND's faziam também referências explícitas ao contexto urbano, assim como a necessidade da preservação e da proteção ao meio ambiente.

No Brasil, foi na década de 1980 que a questão ambiental realmente foi despertada, para a maioria das pessoas, formando o que se pode chamar de uma consciência ecológica. As decisões institucionais importantes datam de 1981, com a aprovação da Política Nacional do Meio Ambiente e as criações do Sistema Nacional do Meio Ambiente - SISNAMA e do Conselho Nacional de meio Ambiente - CONAMA (LEI FEDERAL 1981)

O desenvolvimento nacional desequilibrado pediu medidas urgentes para que os setores menos desenvolvidos pudessem receber insumos financeiros necessários. Claramente buscava-se um desenvolvimento com qualidade de vida e não simplesmente o crescimento quantitativo da produção. Com o passar dos anos verificou-se, entretanto, que nem sempre a qualidade de vida acompanhou o desenvolvimento, quando na realidade esta qualidade devia ser buscada, não só em termos econômicos, mas também ecológicos, de modo a minimizar a degradação ambiental, atendendo não só a uma satisfação individual, mas também a coletiva.

Assim, a eficiência econômica podia ser vista como uma parcela do bemestar social, de um lado, e de outro, do bem-estar individual da população, ambos, entretanto, interdependentes, uma vez que o meio ambiente não podia tornar-se um depósito de produtos imprestáveis que, poderiam agir, com maior ou menor influência no solo, água e ar, desencadeando reações ecológicas que se consubstanciariam em produtos e processos mais ou menos adversos à vida humana.

Paralelamente assistiu-se a um crescimento demográfico que, cada vez mais, acabou por se concentrar nas cidades. As regiões metropolitanas, 
como resultado do poder das grandes aglomerações, formaram-se no Brasil, envolvendo grandes contrastes sociais, com grupos carentes de terra, moradia e trabalho, principalmente, em contraposição àqueles dos proprietários, donos da terra e das grandes firmas empregadoras, e, entre esses dois extremos sociais, nasceu uma camada chamada de classe média.

Esse processo de crescimento demográfico e distribuição de população pelo território mostrou um desenvolvimento sem controle ambiental, que ao lado dos problemas econômicos enfrentados, acabou por ser um difusor de outros problemas, e levou à formação de vários pontos críticos de poluição e degradação do meio ambiente. Face a essa situação, como foi que as administrações públicas puderam enfrentar esses problemas, que cresciam exponencialmente, à medida que a urbanização aumentava cada vez mais?

Nesta fase de desenvolvimento do país, a indústria gerou empregos e, portanto atraiu mão-de-obra, estimulando o aumento da migração interna, que já ocorria do campo para a cidade, e que alcançou nova intensidade, principalmente em direção a esses grandes centros urbanos, as regiões metropolitanas. Se de um lado esse fenômeno levou à formação de um sistema urbano, de ambientes construídos, de outro, direcionou a expansão urbana a ocupar as áreas lindeiras, antes típicas dos usos agrícolas. Estes passaram a se instalar mais adiante, aumentando os custos de transportes para distribuição de seus produtos nos grandes centros.

Entre os anos de 1970 e 1980 em algumas regiões do país ocorreram grandes alterações, pois não só a urbanização desencadeou uma rápida modificação no campo, mas também a tecnologia, trazendo a mecanização da agricultura, para os usos do solo. Quando, por exemplo, o cultivo do café que absorveu grande parte de mão-de-obra foi substituído pela cultura da soja, que ocupava grandes extensões de terra, exigiu pouquíssima mão-de- 
obra comparativamente, pois o cultivo passou a ser essencialmente mecanizado. Iniciou-se assim, um verdadeiro êxodo rural, praticamente instantâneo, em que pessoas antes moradoras no campo, tiveram que buscar novas formas de vida. Foi assim que o Estado do Paraná, nesses dez anos, perdeu cerca de 1,5 milhão de pessoas. Destas, pode-se dizer que poucas foram atraídas para os núcleos urbanos, pois a maioria dirigiuse para a nova fronteira agrícola que se abria a noroeste e norte, acompanhando a construção da rodovia BR 364, que ligava Cuiabá, Estado de Mato Grasso à Porto Velho,Rondônia. Neste período nasceram muitos núcleos urbanos como Alta Floresta, Vilhena, Ji-Paraná entre outros, que deram origem a novos municípios.

Experimentos de reforma agrária também foram feitos nessa ocasião, com projetos especialmente voltados para a fixação do homem no campo. Previu-se que, ao redor dos centros desses novos núcleos urbanos haveria terras de cultivo, cuja posse seria dada ao novo assentado, bem como uma pequena quantia em dinheiro, para que pudesse fazer frente aos primeiros gastos com sementes e insumos necessários à sua plantação. Essa política de desenvolvimento procurava ao mesmo tempo dirigir a ocupação do solo no país, e com isso direcionar todo o desenvolvimento urbano, ao apontar áreas prioritárias para ocupação.

Se essa política urbana tivesse efeitos positivos ao longo dos últimos 30 anos, talvez tivesse moldado uma nova face para o Brasil urbano. Mas, apesar desses empreendimentos visando a fixação do homem no campo, porque os resultados não foram frutíferos? Não se estava atendendo às aspirações da população?

Talvez o fator elemento humano deva ser examinado em primeiro lugar. Estaria preparado para tão rápidas e grandes mudanças? Mudança de Estado, saindo do Paraná. Mudança de tipo de cultura, plantio, com que 
estava acostumado, incluindo outras técnicas agrícolas. Mudança de clima e de grupo social. Como enfrentar simultaneamente tantas transformações em sua forma de vida?

O despreparo do elemento humano, pode-se dizer, estava na origem do fracasso ocorrido com essa política agrícola de colonização. Não obtendo resultados com seu plantio e colheita, não havia como subsistir. A opção se resumia então na venda da terra e na procura de emprego nos centros urbanos mais desenvolvidos. Engrossaram-se as fileiras dos sem teto. Este fato passou a ser mais um dos causadores do inchaço urbano, que nos anos posteriores ao choque do petróleo, 1973 e 1979, viu-se acrescido de outros ex-moradores de áreas rurais, os bóias-frias no Estado de São Paulo, que acabaram também tendo que sair das áreas rurais e procurar as periferias urbanas, em busca de moradia, trabalhando cerca de quatro meses na cidade, em empregos temporários, e outros tantos nas colheitas agrícolas, como a da cana-de-açúcar.

Formas de ocupação do solo como essas deixaram como marcas o impacto negativo no meio ambiente, com desmatamentos, seja de Mata Atlântica, seja do Cerrado. Com a exposição da terra nua e as chuvas, surgiram as erosões com a conseqüente descompactação de camadas do solo. O meio ambiente foi agredido sem qualquer forma de mitigação ou supressão desses efeitos negativos. A riqueza de recursos naturais não justifica uma exploração selvagem, sem controle ambiental. A adequação das atividades humanas é sempre um desafio nesse processo de desenvolvimento, por isto é importante conhecer as características humanas encontradas nas diferentes regiões físico-geográficas (MMA 2000c).

Com o tempo, despertou-se a necessidade de conscientizar a população sobre os efeitos negativos das suas atividades sobre o meio ambiente, muitas das quais decorrentes de políticas públicas, como o exemplo acima 
em que se procurou fixar o homem no campo, com um sistema de colonização e reforma agrária ao longo da rodovia BR 364. Assim, aos poucos, foi ficando clara a importância das políticas públicas e das legislações decorrentes, nos vários níveis de governo. Política e gestão ambiental tornam-se indispensáveis para o desenvolvimento nacional, regional e local.

Em contraste, os países industrializados possuidores de novas tecnologias tiveram garantida sua superioridade de mercado, tanto no campo industrial, como agrícola. Essa tecnologia se traduziu em força econômica e financeira, que, com base numa forte democracia interna já consolidadada, passou também a ser um fator fortalecedor da ação internacional. Com o controle desses dois fatores, determinando os fluxos de aplicação financeira, atraíram a atenção dos governos dos países em desenvolvimento, que freqüentemente precisam de auxílio para re-equilibrar suas combalidas finanças e para permanecerem inseridos no contexto mundial.

Embora dependentes dos sistemas ecológicos de sustentação da vida, os sistemas econômicos não aceitam pacificamente a idéia de complementaridade entre capital natural e capital construído. Para lograr esta aproximação é necessário, além da demonstração e sustentação científica, a ação de educação ambiental que produza transformações na percepção e no comportamento dos agentes econômicos e sociais. A conferência de Tbilisi, sobre educação ambiental, tornou-se um marco ao indicar que a degradação ambiental tem relação direta com o sistema cultural da sociedade industrial, pautada na competitividade como instância reguladora da sociedade, e ao demonstrar as interdependências econômicas, políticas e ecológicas do mundo moderno (LAYRARGUES 2000). 
A interdependência entre nações vem demonstrando a necessidade de ações concertadas em prol da qualidade do meio ambiente, e torna-se uma força indutora da conscientização da necessidade de maior cooperação entre os países, mesmo considerando os diferentes estágios de desenvolvimento.

Em um primeiro momento, mesmo que essa cooperação fosse para mobilizar ou modernizar economias frágeis, acabou por influenciar na formação de uma juventude que procura meios para desenvolver seu país e construir uma democracia ambientalmente responsável e socialmente mais justa. O pacto pela mudança do padrão de desenvolvimento global, como convencionado pelos países reunidos pela Organização das Nações Unidas, destacou prioridades para o século $X X I$, que fazem parte do documento Agenda 21 e representam um movimento em prol do desenvolvimento sustentável e da manutenção da qualidade do meio ambiente (RIO'92 1994).

No Brasil, seguindo o exemplo de alguns países desenvolvidos, procurouse implantar meios para controlar os impactos negativos que resultaram das atividades humanas no território. Assim é que, nos vários níveis de governo, o país se preparou para superar o modelo econômico de tipo desenvolvimentista, eivado de corporativismo e protecionismo, que estava levando as empresas brasileiras a atuarem de forma cada vez menos competitiva, para começar a trilhar o caminho de um desenvolvimento sustentável, (MMA 2000f). Sob esta ótica, organizou-se um programa de transição entre esses modelos de desenvolvimento, ao propugnar a redução das desigualdades sociais com a superação de obstáculos e a criação de melhores meios operativos, focalizando a necessidade de ampliar as oportunidades de educação continuada e extensiva (MMA 2000f). 
Foram desenvolvidas legislações ambientais, desde então implantadas. Com relação à industrialização destaca-se no âmbito federal o zoneamento industrial em áreas críticas de poluição, estabelecido pela Lei 6.803/80, alterada pela Lei 7.804/89, e, no Estado de São Paulo, o zoneamento industrial da região metropolitana de São Paulo, definido pela Lei 1.817/78, e a lei de proteção aos mananciais da metrópole de São Paulo, Leis 898/75 e Lei 1.172/76 e a Lei de Preservação Ambiental do Estado de São Paulo, de 1998. Em nível federal, destacam-se ainda a Lei 9.433 de 08/01/1997 alterada pela Lei 9.984 de 18/07/2000, instituindo a Política Nacional de Recursos Hídricos e criando o Sistema Nacional de Recursos Hídricos, em que a água é considerada um bem natural limitado, dotado de valor econômico e que pode ter usos múltiplos (FIESP/CIESP 2001) e a chamada Lei de Crimes Ambientais, estabelecida pela Lei 9.605 de 12/01/1998.

É importante lembrar ainda, que os meios de comunicação e ensino passaram a agir também como instrumentos de conscientização da população para os tipos de poluição que estavam recrudescendo, oriundos de processos industriais ou agrícolas, ou mesmo da ocupação e uso do solo de forma indevida, sem sistemas de esgotos, com dejetos e o lixo se acumulando em locais indevidos, como nos cursos d'água, devido a um desenvolvimento feito a revelia de controle.

Despontou assim, na população, uma curiosidade, senão interesse, por conhecer os processos com os quais a sociedade se estabelece em uma cidade e região e dela extrai seu sustento. Despertou também uma curiosidade em saber como a gestão ambiental pode influir na qualidade de vida. Abriu-se, portanto, o caminho para que os diferentes níveis governamentais sejam estimulados a aprovar legislações ambientais e urbanísticas, com as quais se possa enfrentar os problemas mencionados e controlar as condições de vida urbana, assim como a qualidade ambiental resultante. 


\subsection{Gestão Ambiental: marcos teóricos}

Destacou-se, em um primeiro momento, um projeto de desenvolvimento urbano resultante da política pública de abrir estradas, procurando conter o crescimento desmensurado das grandes aglomerações metropolitanas, e criando outros pólos de crescimento junto a cidades de porte médio, para que pudessem receber e fixar parte dessa migração interna rural-urbana.

Pode-se entender que a teoria das economias e deseconomias das aglomerações tenha fundamentado a compreensão do movimento de população no território, ou seja, a migração interna, e por isso tenha sido tomada como base para a concepção das políticas públicas então adotadas nos PNDs.

Outra teoria importante que foi utilizada nas políticas públicas nacionais é a dos pólos de crescimento, trazida da França, e posteriormente dos Estados Unidos, e replicada ainda pela Comissão Econômica para a América Latina e o Caribe. Por essa teoria, o desenvolvimento seria gerado pela atração de um centro polarizador de atividades econômicas e sociais, que portanto, deveria ser estruturado de forma a oferecer à população, bens e serviços, incluindo dentre esses, toda uma gama de atendimento social, com escolas e centros de saúde, para que pudesse não só atrair, mas fixar a população em suas imediações.

Como originalmente criada, essa teoria tinha a força do desenvolvimento ligada às atividades do setor secundário, ou seja, às atividades industriais. Muitos foram os projetos realizados com essa característica, em vários países, ainda que não se possa dizer que a localização industrial tenha 
trazido desenvolvimento para as áreas alvo desses projetos. Posteriormente, além do setor secundário, pensou-se que o setor terciário da economia seria importante para gerar o desenvolvimento em certos casos, como o programa nacional das cidades de porte médio no Brasil.

Daí as políticas públicas então estruturadas, terem esse forte componente do setor terciário, voltado para a implantação de serviços sociais, além da infra-estrutura urbana, pois esses projetos deveriam gerar os efeitos esperados, em curto prazo de tempo, redirecionando o fluxo migratório no território nacional, no caso do programa de cidades e capitais de porte médio, à medida que estas conseguissem fixar a população que originariamente se dirigiria para as congestionadas e mesmo saturadas regiões metropolitanas (STEINBERGER \& BRUNA 2001).

As estratégias setoriais e regionais de desenvolvimento no país, durante as décadas de 1970 e 1980, voltaram-se para explorar programas baseados nas vantagens competitivas nacionais, nos esforços concentrados e integrados entre as organizações, nas ações nacionais em prol da educação, e propugnando uma integração entre as diferentes regiões, no esforço excepcional de gerar empregos e reduzir as desigualdades. A palavra de ordem era crescer setorialmente para poder controlar a expansão urbana e o desenvolvimento. O país cresceu em torno dos grandes projetos nacionais, de distribuição nacional da localização de certos tipos de indústrias, como a siderurgia e a petroquímica, os projetos de desenvolvimento de portos, a construção de grandes hidroelétricas e de importantes rodovias nacionais, dentre outros. Foi um período de uma gestão nacional fortemente centralizada no governo federal. Dava-se ênfase às ações coordenadas em torno de prioridades mundiais, para que o país pudesse se equilibrar em termos de comércio exterior e enfrentar a globalização dos mercados (FURTADO 1992). 
O aumento da percepção da questão ambiental gerou, em contrapartida, o aumento de pressões demandando soluções para os graves problemas que passaram a ameaçar a população como um todo, ou grupos específicos enfrentando situações ímpares, como a contaminação do solo por resíduos de processos industriais, cujos dramas, vividos por um grande número de pessoas, vêm sendo desde então retratados em todas as mídias. A empresa Rhodia, por exemplo, localizada em São Vicente, São Paulo, por exemplo, foi responsabilizada pela disposição no solo, de resíduos industriais tóxicos. Além de autuada por ação judicial, a indústria teve que desenvolver um plano de recuperação das áreas contaminadas.

Despontou assim uma consciência ambiental, que se fortaleceu no âmbito do mundo democrático, no qual as gestões eram cada vez mais descentralizadas, com o poder local ampliando suas responsabilidades por políticas de desenvolvimento e de controle da qualidade ambiental. A essas demandas, juntou-se a necessidade de modernização tecnológica das atividades e indústrias, o que atualmente vem sendo feito com eficiência em algumas regiões e setores do país. Mas, como não podia deixar de ser, essas ações geraram necessidades expressas prioritariamente em demandas de políticas e ações pró ativas e sustentáveis, com controle dos impactos ambientais, com qualidade de produção e consumo, e com preservação da maior riqueza mundial, que são os recursos ambientais nem sempre renováveis, e que necessitam de ajustes mundiais para manter sua capacidade de suporte para as civilizações futuras.

Não foi mais possível agir setorialmente. De um lado e de outro, as estratégias adotadas mereceram um enfoque integrado, que aliou crescimento à preservação ambiental. Houve necessidade de estratégias de desenvolvimento de maior complexidade, para o que foi necessário envolver tanto o setor público, como o privado e mesmo a sociedade civil interessada. 
Em termos de processos produtivos, passou-se a cogitar da opção por determinados tipos de matérias-primas, e, conseqüentemente, da opção por certos processos produtivos em detrimento de outros. Houve necessidade de aumentar o controle de resíduos, e estimular a geração de sinergia entre os setores público e privado para inovar na tomada de decisões, imperiosamente necessárias para a implantação de estratégias com essas diretrizes.

Em termos de gestão ambiental, as iniciativas pró-sustentabilidade têm origem em alguns fatores, sem os quais talvez a humanidade não tivesse adquirido conhecimentos suficientes para poder entender o fenômeno do consumo dos recursos naturais não renováveis. Não se trata simplesmente de saber que o petróleo é uma riqueza finita, que pode durar mais alguns anos, 50 ou 60. Trata-se de muito mais conhecimentos nas áreas médica e biológica, que mostrem a natureza dos processos de transformação dos organismos vivos, e as possibilidades de interagir com eles, procurando soluções para a decadência de suas partes e órgãos, bem como para doenças invasoras ou auto-imunes.

Atualmente, parte da humanidade atingiu um nível de tal qualidade de vida, que não pode se dar conta do que seria perder esse estado-de-bem-estar. Por isto, precisa solucionar os inúmeros problemas que gerou no decurso da civilização, consciente ou inconscientemente. Produtos como veículos motorizados, indústria química, siderúrgica, petroquímica e fertilizantes têm um alto poder poluidor. Conseqüentemente, o processo de urbanização construído a partir desse tipo de produção econômica, traz em si próprio o gérmen que pode torná-lo insustentável.

Copiar, portanto, os países desenvolvidos, por vezes recebendo equipamentos e tecnologias superadas, não faz com que um país em desenvolvimento adquira o controle desse processo e, muito menos, 
domine-o, a ponto de suprimir etapas nessa corrida pró desenvolvimento e poder contornar os seus efeitos negativos, levando-o a um patamar superior de controle da poluição aí gerada. Nesses casos em geral, aumenta gradativamente a distância das camadas da população que têm acesso a bens e serviços, principalmente aqueles referentes ao saneamento, das que nada tem.

Desastres ambientais podem ocorrer sem que possam ser previstos, e portanto, sem que possam ser atenuados, uma vez que a utilização indiscriminada de produtos e matérias-primas está continua e lentamente formando futuros desastres. Esse modelo de desenvolvimento, tão difícil de ser abandonado e substituído, tem raízes nas dificuldades da população em considerar o meio ambiente como um bem escasso, até mesmo insubstituível, que merece ser conservado acima de tudo e de todos, por meio de processos de controle ambiental, voltados à preservação da saúde da população.

Deste modo, a questão ambiental precisa ser contemplada nos programas de governo, de modo a aguçar a percepção dos cidadãos, e convoca-los a participar, em um esforço conjunto, na busca de soluções para o problema ambiental originado no próprio sistema econômico de produção mundial e, em particular no nacional.

Em vários grupos da sociedade passou-se a discutir questões como: quem poluiu, deve necessariamente contribuir para mitigar ou reverter esses danos? Quem poluiu, deve pagar para permitir que os danos ambientais que causou possam ser sanados ou mitigados? Esse pagamento, é uma indenização à sociedade pelos custos que acrescenta à gestão urbana, ao poluir o ambiente?

Vale lembrar que Resoluções do Conselho Nacional de Meio Ambiente CONAMA, de âmbito federal, regulamentaram a questão ambiental para 
todo o país. O desenvolvimento, em bases sustentáveis, passa a ser um ponto importante nas políticas públicas, nos diferentes níveis de governo. A gestão ambiental torna-se uma meta municipal, pois é no nível local que ocorrem o uso e ocupação do território, com maior ou menor grau de interferência no meio ambiente. No âmbito regional, destacam-se os estados, com suas políticas próprias e respectivas competências de gestão, conforme reza a Constituição Federal. Em nível nacional, a preocupação volta-se para estabelecer as diretrizes básicas das atividades que afetam o meio ambiente.

Assim, a partir da sua resolução 01/86, o CONAMA estabeleceu que a implantação de qualquer atividade econômica que pudesse afetar o meio ambiente em proporções significativas, deveria ser alvo de Estudo de Impacto Ambiental e de Relatório de Impacto sobre o Meio Ambiente EIA/RIMA. Em outras palavras, a construção de estradas, indústrias e aterros sanitários, por exemplo, devem apresentar seus EIA/RIMA, demonstrando os tipos de impactos esperados, negativos e positivos, e propondo medidas saneadoras, ou alternativas, se for o caso. Se esses EIA/RIMA não forem aprovados, os respectivos empreendimentos não poderão ser construídos.

O princípio do desenvolvimento sustentável ganhou força, à medida em que se buscou conceber um desenvolvimento que não prejudicasse a capacidade de suporte do território, tanto para a geração presente, como para as próximas. Para tanto, é preciso que a população possa exercer seu direito de cidadania, participando das principais decisões relativas ao planejamento territorial e ambiental, enquanto lócus do desenvolvimento de atividades humanas.

Como se vê, fica, cada vez mais claro para a sociedade, a importância de uma gestão ambiental integrada e eficaz. Esta é indispensável para o desenvolvimento local, regional e nacional, pois cada uma das entidades 
administrativas, em seus diferentes níveis, deve implementar sua gestão ambiental. Dessa maneira, estar-se-á evitando que, mais cedo ou mais tarde, a sociedade se depare com áreas ambientais e urbanas degradadas. É preciso que sejam criadas condições, para que cada sociedade possa almejar e trabalhar pró desenvolvimento sustentável, isto é, aquele desenvolvimento que não comprometa o meio ambiente, que não esgote seus recursos, cuja produção satisfaça suas necessidades e cujos processos sejam devidamente controlados e não agridam o ar, a água e o solo, vale dizer, os elementos vivos do planeta.

Reforçando esses objetivos, toma vulto o Princípio Poluidor Pagador. As administrações passam a encontrar nesse princípio, um forte aliado para o controle de impactos negativos ao meio ambiente, e a população em geral começou a ver nessa atitude de governos, um cuidado especial com a saúde pública. Desenvolve-se a responsabilidade da comunidade, pois não é mais possível impor, a terceiros, os problemas ambientais advindos de externalidades negativas. É preciso responsabilizar os agentes diretos dessa agressão ambiental, os causadores dos danos ambientais. Só assim estes irão reagir pró ativamente e se interessar pela solução dos problemas que vêm causando. Essa responsabilidade engloba, não só os aspectos monetários, mas estende para uma responsabilidade criminal, conforme a categoria e conseqüências do impacto causado.

Assim é que, o atendimento ao Princípio Poluidor Pagador ganhou importância nas políticas ambientais, e levou à institucionalização, entre outras, da Lei de Crimes Ambientais de 1998 que prevê responsabilidade criminal para o causador de conduta ou atividade lesiva ao meio ambiente, submetendo-o, conforme o caso, a penas de multa, privação de liberdade ou restrição de direito. 
Desse modo, verifica-se uma aproximação entre custos privados e sociais, ao se acelerar, com a homologação desta legislação, a implantação de soluções para o controle da poluição. Possibilitando mudanças comportamentais por parte do poder público, essa lei tem influenciado diretamente os grupos empresariais, exercendo uma forte pressão em prol da adoção de tecnologias não poluidoras de um lado, e de outro, gerando um efeito psico-social na sociedade como um todo, mostrando que o meio ambiente tem um valor monetário e material, e que não pode, portanto, ser alterado impunemente, principalmente se trouxer conseqüências negativas às comunidades, às diferentes regiões ou mesmo ao país.

Essas mudanças comportamentais fizeram com que o Princípio Poluidor Pagador fosse considerado um marco de referência para a análise e seleção de instrumentos de intervenção sócio-econômica, atuando diretamente em prol de uma produção e consumo sustentáveis.

As desigualdades sociais e a visão antropocêntrica, em que os seres humanos teriam o direito de degradar o ambiente, são fatores que exigem uma mudança nas concepções de desenvolvimento, estabelecendo-se, como conseqüência, os parâmetros da sustentabilidade (MINAYO 2000).

As dimensões desta sustentabilidade, em número de cinco, devem ser consideradas simultaneamente, de acordo com SACHS 1993. Assim é que, sustentabilidade social envolve maior eqüidade na distribuição de venda e de bens; sustentabilidade econômica deve ser avaliada em termos macrosociais e não apenas por rentabilidade empresarial; sustentabilidade ecológica possibilitando uso de recursos dos diversos ecossistemas com mínimo de danos aos sistemas de sustentação da vida; sustentabilidade espacial direcionada para uma configuração urbano-rural e distribuição territorial melhor equilibradas; e sustentabilidade cultural voltada a processos de mudanças na continuidade cultura (SACHS 1993). 
Falta, portanto, agregar à ciência econômica, o não econômico, como diz Morin. Esta é uma ciência com as qualidades de matematização e formalização rigorosas e sofisticadas e com o defeito de uma abstração que a separa do contexto social, cultural e político, esquecendo a complexidade do real, ou seja, esquecendo que a economia dela depende (MORIN 1993).

Pode-se dizer então que, o princípio do desenvolvimento sustentável é aquele em que o desenvolvimento da sociedade ocorre associado ao estabelecimento e respeito às políticas públicas, com interpretação ambiental, social e econômica, e contando com o exercício da cidadania, por parte dos elementos que compõe essa sociedade.

Há necessidade, portanto, a curto e médio prazo, de se poder contar com um conjunto de legislações ambientais, com restrições legais de uso do solo, e com uma fiscalização ambiental efetiva. A longo prazo, há que pensar em estratégias que estimulem, amplamente, modificações de comportamento, para que os vários segmentos da população possam decidir, consciente e responsavelmente, sobre ações sociais e econômicas sustentáveis. Vale dizer, que devem estar prontos a abrir mão de antigas técnicas, formas e procedimentos sociais, bem como de processos produtivos, de modo a reduzir custos e desperdícios e aptos a empregar tecnologias mais limpas e sustentáveis. Novos mecanismos econômicos podem, então, estimular uma produção sustentável, apoiando-se para tanto, em processo de educação ambiental da população, que contemple necessidades pertinentes às faixas etárias e à atuação profissional. Esses novos valores culturais, provenientes da consciência e da agudização dos problemas ambientais, são a chave da valorização dessas questões e a mola propulsora de desenvolvimento com qualidade ambiental. 
A pressão por participação da população, nas principais decisões administrativas e políticas, evidenciou-se na segunda metade da década de 1980, com a campanha nacional por eleições democráticas, expressa pelo lema Diretas Já, ou seja, clamava-se por eleições diretas.

Correntes populares começaram a aparecer no cenário de atuação do poder público, agora apoiadas pelas experiências dos Conselhos, tanto do CONAMA como do CONSEMA, este último, o Conselho Estadual de Meio Ambiente do Estado de São Paulo. Um dos méritos desses conselhos, como uma espécie de escola pública de aprendizagem sobre o meio ambiente, é o de ser pelo menos bipartite, pois dele participam, de um lado, os representantes do Governo, e de outro, a Sociedade.

Planos, programas e projetos são analisados e discutidos nesses Conselhos, gerando um clima de debate, com o respectivo aprendizado. A Constituição Federal, aprovada em 1988, é o resultado da participação de muitos grupos da sociedade, cada qual levando suas propostas, e atuando nas sessões durante as discussões. Outro exemplo de participação da sociedade foi a conferência Rio 92, onde foi demontrado que é possível chegar-se a um consenso, tanto em termos nacionais, como ao nível de Nações. Como resultado obteve-se o compromisso da Agenda 21, que cada país deve produzir como forma de cooperação internacional para a mitigação dos efeitos nocivos oriundos de uma forma de desenvolvimento não sustentável (MMA 2000a).

Observa-se assim, com o passar do tempo, que a gestão ambiental ganha em importância, tanto em relação aos governos, que precisam implementar políticas públicas, como em relação à população que espera resultados dessas políticas, com base em participação nos diferentes estágios de sua formulação e aprovação. Assim é que, a participação passa a ser considerada como condição essencial não só para a formulação de políticas 
mais eqüitativas e democráticas, mas também para a própria eficácia, eficiência e efetividade do planejamento e da gestão (DOWBOR 1994).

\subsection{Gestão e Globalização}

$\mathrm{Na}$ década de 70, países mais desenvolvidos economicamente estabeleceram suas políticas públicas de meio ambiente. Nesses anos aconteceram reuniões de governos, instituições de ensino e pesquisa e organizações não governamentais, com grandes discussões em Conferências Internacionais das Nações Unidas, como a do Meio Ambiente realizada em Estocolmo, Suécia, em 1972 e a de assentamentos humanos, Habitat I, realizada em Vancouver, Canadá, em 1976. Presenciaram-se movimentos populares em torno da proteção ambiental, formados pelos grupos de cidadãos e profissionais do meio ambiente, chamados genericamente de ambientalistas. Atuavam em várias questões como proteção às baleias, aos manguezais, aos litorais, quando havia vazamento de petróleo e comprometimento de grandes extensões de oceano, ou em relação ao lixo atômico cuja guarda por exemplo, ficava a cargo de determinada nação.

Questões como essas, pode-se dizer, influenciaram a forma de pensar de governantes em diversas partes mundo, pois estes se pronunciavam em nome dos respectivos países, com a preocupação coletiva de proteger o ambiente humano para as gerações futuras, em especial as reservas de recursos não-renováveis e o comprometimento do solo, água e ar do planeta como um todo.

Há, contudo, algumas regiões que são mais privilegiadas quando se trata de gerar economia; pelo menos é o que dá a entender MOOG, em seu livro Bandeirantes e Pioneiros. Sua obra desenvolve a tese de que os países de clima frio e temperado têm melhores condições de se desenvolver do que 
os países de clima quente, como é o Brasil tropical; por isso demonstra cabalmente que, nos Estados Unidos, o principal impulso do seu desenvolvimento se baseou na necessidade de se preparar para enfrentar os invernos rigorosos (MOOG 1974).

Por muitos e muitos anos, então, o desenvolvimento resultante do trabalho humano foi pregado como meta a ser atingida por um país que desejasse ser considerado entre os mais importantes. Em contrapartida, pouco ou quase nada se mencionava a respeito das conseqüências desse desenvolvimento sobre o meio ambiente natural e construído, que vinha sendo prejudicado em decorrência da exploração irracional de seus recursos, até mesmo tornando-se depositário da sujeira gerada pelas atividades humanas.

A realidade apresenta então a "crescente contradição entre o ecossistema do planeta terra, que é finito, e a acumulação de capital, que é tendencialmente infinita". Desta forma, o termo desenvolvimento sustentável apresenta um caráter eminentemente utópico, sendo... "que a utopia ecológica é utópica porque a sua realização pressupõe a transformação global, não só dos modos de produção, mas também do conhecimento científico, dos quadros de vida, das formas de sociabilidade e dos universos simbólicos e pressupõe, acima de tudo, uma nova relação paradigmática com a natureza" (Santos 1999).

Assim, sem que a humanidade percebesse, estava, pois, colocada historicamente uma questão: a questão ambiental. Ou seja, criou-se um problema para o meio ambiente, que passou a incluir, além do ambiente natural, também o ambiente urbano, ambos marcados por uma ocupação indiscriminada do território e pela aceitação ingênua ou inescrupulosa de qualquer tecnologia, desde que gerasse lucro e haveres comerciais. Isto se 
constituiu no estopim de muitas crises ambientais, em que o patrimônio natural da humanidade vem sendo dilapidado.

Tal panorama incluía os países em desenvolvimento, dentre os quais o Brasil, que continuava a estimular o crescimento a todo custo, seja pela política de substituição de importações, abrindo espaço para o fortalecimento da indústria nacional, seja pela transferência de tecnologias estrangeiras, absorvendo, então, processos produtivos antigos e ultrapassados, que tinham sido substituídos por outros mais avançados no país de origem. Nessa trajetória, não havia preocupação com qualquer tipo de poluição.

O desenvolvimento vinculava-se diretamente à dependência dos países desenvolvidos, tanto em termos de tecnologia para a produção industrial, quanto em termos de mercado para a absorção da produção primária. FURTADO (1991), é da opinião de que a industrialização no Brasil não resultou tão-somente de uma política de caso pensado; ela se deveu muito mais às pressões do sistema produtivo, tanto as motivadas pela conjuntura internacional nos períodos de depressão e de guerra, quanto pela ação do governo na defesa dos interesses do principal produto de exportação. Pode-se dizer que no outro lado dessa teoria, e que a complementa, está a do subdesenvolvimento, por meio da qual o progresso tecnológico é feito com base na demanda de bens finais de consumo, o que levou o país a importar tecnologias já ultrapassadas nos países de sua origem (FURTADO 1992).

Os resultados ambientais dessas pressões do sistema produtivo se fizeram sentir em diversos pontos do país. Com efeito, a enorme concentração de indústrias em São Paulo foi acompanhada de um crescimento urbano descomunal. Houve, pois, a formação de grandes complexos industriais, 
ponto de partida do processo de degradação ambiental provocado pelos despejos dos seus efluentes na água, ar e solo.

Complexos industriais e crescimento urbano que provocaram intensa ocupação do solo, tornando-o impermeável e resultando em um aumento de áreas urbanas inundáveis. Terrenos impróprios e com sensível declividade foram ocupados, tornarando-se novas áreas com risco de deslizamento de terra, soterrando pessoas e fazendo desabar construções precárias. À alta densidade demográfica seguiu-se uma não-contida geração de lixo, que se acumulou em locais inadequados, transformando-os em focos de artrópodes e roedores nocivos à saúde das pessoas. Os assentamentos humanos, por sua vez, surgidos pela corrida dos tempos modernos, na falta de infra-estrutura urbana, lançam seus esgotos in natura, agravando cada vez mais o estado das águas nos córregos, rios e reservatórios.

As diversas formas de poluição e degradação ambiental geram uma situação de descalabro da saúde pública, na respeitável região metropolitana de São Paulo, que atualmente, abriga cerca de 17 milhões de habitantes, ameaçados pela falência de sistemas urbanos. Esta ameaça afeta também outras regiões vizinhas, das quais passou a importar água e a exportar processos produtivos, sem os adequados prevenção e controle da poluição e degradação ambiental.

Talvez fosse importante reforçar que está referindo-se à intervenção considerada desastrosa, muitas vezes gananciosa, do ser humano, e não à evolução gradativa da própria humanidade que, em tese, deveria respeitar os ciclos da natureza, dando-lhe tempo e condições de se recompor por conta própria. 
A evidência do adjetivo que qualifica essa intervenção, desastrosa, se deduz da constatação de que o acelerado processo de desenvolvimento industrial, vem comprometendo de modo assustador a qualidade desse planeta. Mesmo trazendo inegáveis benefícios para a humanidade em geral, já deixava antever com evidência que os recursos da natureza, sempre ilusoriamente considerada depositária de jazidas eternas, iam se esgotando. Apesar de todo progresso trazido pela industrialização, assim mesmo, globalmente, para uma privilegiada minoria, vem-se ecolocando em risco a da qualidade do ambiente e, conseqüentemente, da vida. Chega-se, pois, à conclusão de que, mesmo em países tidos como desenvolvidos, portanto industrializados, o preço desse modelo de progresso estava muito alto em termos ambientais.

A conscientização sobre os cuidados que deveriam ser tomados em relação à capacidade de sustentação ambiental, vem sendo feita de uma maneira muito lenta ao longo da história e, por isso mesmo, talvez tenha se perdido com as civilizações que desapareceram. Mais recentemente, entretanto, verifica-se um esforço em nível mundial em prol do reconhecimento da necessidade de preservar, proteger e recuperar o meio ambiente, e da importância de as gerações buscarem modos de desenvolvimento sustentáveis, a fim de viabilizar a vida neste planeta.

Essa conscientização, promovida muitas vezes por organismos internacionais, muito relacionados à Organização das Nações Unidas, por meio de conferências, como, por exemplo, sobre meio ambiente humano, em 1972 em Estocolmo, Suécia, sobre assentamentos humanos, em 1976, com o Habitat I em Vancouver, Canadá, sobre meio ambiente e desenvolvimento, em 1992, no Rio de Janeiro, Brasil, sobre assentamentos humanos, em 1996, com o Habitat II em Istambul, Turquia, sobre Educação Ambiental, em 1997 em Tbilisi, Geórgia, e 1997 em Tessalônica, Grécia, certamente foram precedidas de inúmeras outras formas de difusão, seja por fábulas, seja por ensaios e obras descritivas da natureza. 
Mais recentemente tem-se assistido a inúmeros seminários técnicos, congressos e conferências em âmbito nacional e internacional, levantando questões polêmicas sobre a ocupação indiscriminada do território, pela aceitação de tecnologias que visam unicamente o lucro, e não se adaptam à capacidade de suporte dos ambientes em que se inserem. Em outras ocasiões, é a mídia que assinala os resultados danosos dessas tecnologias apontando, o desaparecimento de espécies vegetais e animais. Em vários casos, há regiões recebendo água de outras bacias, pois os recursos hídricos da bacia em que os assentamentos estão fixados, já não é suficiente para o abastecimento de sua própria população.

Aqueles que moram em cidades, e metrópoles, por exemplo, se conscientizam da necessidade da gestão ambiental, devido a pesadelos que vêm se tornando realidade, como a falta de água e de energia, determinando, em muitos casos, a necessidade de rodízio de dias, em que determinada zona urbana é suprida com água, ou, ainda, períodos em que a região fica às escuras.

Aqueles que vivem no campo, chegam à realidade dos problemas ambientais, e da mesma forma se conscientizam da necessidade de gestão ambiental, quando vêem desaparecer espécies vegetais e animais, quando a chuva ácida queima suas plantações, quando a seca torna-se mais freqüente devido aos desmatamentos e ao desaparecimento das florestas...

Por essas razões, a questão ambiental incita as sociedades a conhecer os esforços feitos por aqueles países, que exercam ações sobre as condições do meio ambiente, por meio de programas de controle da poluição das águas, do ar e do solo. Como exemplo, pode ser mencionada a Inglaterra que se orgulha de ter conseguido devolver a qualidade das águas ao rio Tâmisa e por ter exercido o controle sobre a poluição atmosférica nas áreas 
industriais dos Midlands, em especial a cidade de Manchester, então símbolo de tudo o que era mais poluído.

Na França, Paris devolveu a vida ao rio Sena. Na Alemanha, a região industrial do Ruhr conseguiu controlar sua poluição atmosférica.

Em termos práticos, pode-se recorrer ao ideário recente de saúde ambiental no Brasil, voltando-se para os idos de 1972, no período pós-Conferência das Nações Unidas sobre Meio Ambiente Humano, realizado naquele ano em Estocolmo. Este é considerado um marco das questões ambientais, quando o mundo procura compreender e discutir os problemas do meio ambiente em escala global, buscando respostas a sérias questões e controvérsias, coordenando ações e procurando definir linhas de atuações futuras.

Dá-se o início de uma nova filosofia, cujas diretrizes tiveram origem no próprio modo de pensar da Organização das Nações Unidas, em 1972. E, na esteira da declaração dos princípios e das resoluções de Estocolmo, foi criada, no ano de 1983, a Comissão Mundial sobre Meio Ambiente e Desenvolvimento. Entraram, assim, em cena, os elementos necessários para delinear estratégias de ação à maneira da apresentação de uma avant -première que ensaia uma Agenda Global para Mudanças.

Os trabalhos dessa comissão foram sendo desenvolvidos durante os anos seguintes e, uma vez completados, chegaram ao conhecimento do público em 1987, apresentados com o sugestivo título Nosso Futuro Comum, ainda que sob a forma de um relatório final, também conhecido como Relatório Brundtland, fazendo menção direta à coordenadora da comissão, Gro Harlem Brundtland, Primeira-Ministra da Noruega. 
Desde essa época, a sociedade mundial passou a ter em mãos um plano, que se transformou numa referência básica de abrangência internacional, para que a Organização das Nações Unidas pudesse preparar a Conferência sobre o Meio Ambiente e Desenvolvimento (CNUMAD 1992), realizada no Rio de Janeiro, conhecida por Rio 92.

Mesmo decorridos vinte longos anos, desde a Conferência de Estocolmo em 1972, a sociedade internacional, que acompanhou de longe e com curiosidade as notícias do encontro de 92, ou que participou in loco dos seus debates, pôde conhecer uma série de acordos e compromissos coletivos firmados pelas representações governamentais que então estiveram presentes no Rio de Janeiro.

Dessa série, cumpre destacar a Agenda 21, a Convenção sobre Diversidade Biológica, a Convenção sobre Mudança Climática e o documento final, a Declaração do Rio de Janeiro sobre Meio Ambiente e Desenvolvimento, com vinte e sete princípios sobre os direitos de todos à um ambiente saudável, e os deveres dos governantes de promover o exercício desse direito.

A Agenda 21, fruto de grande significado do evento, é o documento que estabelece o programa de ação dirigido à aplicação de princípios voltados à obtenção de melhoria das condições ambientais e, conseqüentemente, de vida, das sociedades em todos os Estados Nacionais. Disposto em quarenta capítulos, que refletem o consenso universal sobre os assuntos tratados, registra ainda o grande esforço a ser despendido na construção de uma pauta comum.

Acordos mundiais não se limitaram ao período da duração da Conferência do Rio de Janeiro. Em 1993 houve a Reunião dos Chefes de Estado do Continente Americano, realizado em Salvador (Brasil), e em 1994 reuniu-se 
a Cúpula das Américas, em Miami (EUA), ambos os eventos à procura de uma integração regional das Américas, em cujas pautas, entre outros temas, focalizaram detidamente os assuntos saúde e ambiente.

O impacto da Conferência de Estocolmo se fez sentir oficialmente no Brasil no início dos anos de 1980, como testemunha a Lei $n^{\circ} 6.938$, de 31 de agosto de 1981, instituindo a Política Nacional do Meio Ambiente. Independentemente, contudo, da instituição dessa política nacional, por essa ocasião também foram criadas diversas secretaria estaduais de meio ambiente, cujo exemplo foi seguido por alguns municípios no final da década.

A década seguinte de 1990, assiste ao despertar de uma consciência na esfera do poder público, que o leva a tratar com mais cuidado as áreas verdes naturais e os espaços urbanos construídos. É bem verdade que a questão do verde, o chamado verde ecológico, tomou maior impulso e passou a concorrer e a disputar espaço com o saneamento básico na atenção dos administradores públicos.

Dessa maneira, nota-se que a trajetória das questões ambientais e suas implicações com a saúde está seguindo um caminho de integração mundial, na busca de soluções de caráter global, porque governos e governados estão gradualmente descobrindo que um país não resolve isoladamente os seus problemas. Aliás, não poderia ser diferente, uma vez que todos os povos estão conectados pela biosfera e, hoje, com maior intensidade, amarrados pelos elos do intercâmbio comercial. A necessidade de integração torna também prementes os processos de globalização ou de regionalização da economia, como é o caso dos países da América do Sul que, em 1995 formaram o Mercado Comum do Cone Sul, o Mercosul, destinado inicialmente a unir economicamente o Brasil, o Paraguai, o Uruguai e a Argentina. A partir desse dado político-econômico, manifesta-se 
a urgência de se estabelecerem negociações regionais para promover uma integração normativa que vá ao encontro dos novos fluxos de mercadorias, de bens e serviços e de recursos humanos. Nas pegadas desses novos fluxos, promover igualmente uma integração que favoreça a promoção e a manutenção da qualidade do meio ambiente e da saúde nos país da região.

\subsection{A Capacitação ambiental de recursos humanos}

A exigência de dar ação e conseqüência à planos, programas, projetos, e atividades, com as características exigidas pelos desafios ambientais, consolida a necessidade de uma gestão ambiental, demandadora de profissionais com visão de conjunto e capacitado para compreender e exercitar processos de mediação de interesses e conflitos entre atores sociais que agem sobre os ambientes natural e construído.

É fundamental lembrar que a gestão ambiental não é neutra. Ao assumir-se determinada postura diante de um problema ambiental, está-se definindo quem fica com os custos e quem fica com os benefícios da ação antrópica. Daí a necessidade de se contar com profissionais qualificados, que compreendam que seu compromisso deve ser com a redução da assimetria, na distribuição de custos e benefícios, na prática da gestão ambiental.

É sabido que o acervo e o formato científico-tecnológico, montado apenas em bases disciplinares, perde sua força quando se trata de equacionar problemas de poluição ou de degradação do meio ambiente. Daí a proposta de avançar epistemologicamente no sentido de provocar a integração das diferentes interfaces com as quais se apresentam as questões de ordem ambiental.

Os registros que indicam a existência dos primeiros órgãos e ações de controle ambiental no Brasil, datam do início dos anos 70. Mesmo assim, 
são recentes e escassas as experiências com equipes multidisciplinares nesse campo. Hoje ainda, a maioria das instituições que se dedica ao assunto encontra-se cuidando de formar ou de consolidar suas equipes.

A descentralização, a integralização e a inter setorialidade, processos e atuação associados aos marcos legais e institucionais do país, criam novas demandas de profissionais, em quantidade e com características tais que possam desenvolver diálogo interdisciplinar, com incorporação de métodos e tecnologias condizentes com o conceito de desenvolvimento sustentável (COPASAD 1995).

São dados que vêm dar maior força à necessidade de incrementar a formação e capacitação de recursos humanos, visando ampliar o conhecimento científico e tecnológico, orientado para uma nova visão da economia, da sociedade e do ser humano, tornando-os aptos a enfrentar os desafios trazidos pela nova ordem mundial, nacional, regional e local.

A clara identificação das necessidades de formação e capacitação de recursos humanos para a área ambiental, em especial para a gestão ambiental, recomenda algumas reflexões quanto ao profissional a ser preparado.

Primeiramente a lembrança de que a "universidade é um espaço de produção e difusão do conhecimento, ao mesmo tempo em que é um espaço de formação de profissionais de todas as categorias para a nossa sociedade, que estarão em plena atividade como cidadãos e como profissionais" (MASSETO 1998). 
Segundo Pelicioni (2000), tanto a "formação como a capacitação e atualização de docentes por meio de uma educação continuada, são fatores importantes e precisam contar com a participação de universidades das instituições responsáveis pela formação de professores e de ONGs." Portanto, nos "programas de capacitação deve-se utilizar métodos práticos e interativos e incluir experiências de campo, além de possibilitar os conhecimentos necessários para o desenvolvimento profissional" (PELICIONI 2000).

O conhecimento, como novo poder, estabiliza ou desestabiliza governos, políticas e empresas. "Invade a área de recursos humanos, exigindo qualidade de serviços, revisão de categorias ocupacionais, formação continuada de profissionais, novas capacitações, que combinam imaginação e ação" (MASSETO 1998).

Segundo FREIRE (1999), "o ensino exige reflexão crítica sobre a prática. Por isso é que, na formação permanente, o momento fundamental é o da reflexão crítica sobre a prática. É pensando criticamente a prática de hoje ou de ontem que se pode melhorar a próxima prática. O próprio discurso teórico, necessário à reflexão crítica, tem de ser de tal modo concreto, que quase se confunde com a prática" (FREIRE 1999).

É fundamental perceber que a realidade na qual os seres humanos vivem, é a criação dos homens. Assim, ela não pode transformar-se por si só, mas depende da ação do homem.

Para este autor, ao analisar o compromisso do profissional com a sociedade, é preciso reconhecer que antes de ser profissional, cada indivíduo, como homem, deve ser comprometido consigo mesmo e com sua humanidade. "Quanto mais me capacito como profissional, quanto mais sistematizo minhas experiências, quanto mais me utilizo do patrimônio 
cultural, que é patrimônio de todos e ao qual todos devem servir, mais aumenta minha responsabilidade com os homens" (FREIRE 1983).

É esperado que o profissional pretendido para a gestão ambiental, tenha características tais que exercite, ao longo de sua formação, sua capacidade de reflexão, com base em uma ética para a sustentabilidade, que promova a gestão participativa dos bens e serviços ambientais, a coexistência de direitos coletivos e individuais; a satisfação de necessidades básicas, realizações pessoais e aspirações culturais dos diferentes grupos sociais.

O projeto implementado pela Faculdade de Saúde Pública, em conjunto com a Faculdade de Arquitetura e Urbanismo, de capacitação em gestão ambiental, levou em consideração estas perspectivas, ao longo do programa.

Nestas circunstâncias, é importante renovar compromissos, onde "mais do que a concentração em áreas muito específicas, o ensino universitário exige a percepção da universalidade do saber, não apenas na congregação de muitos saberes. Nenhum curso, e muito menos um curso de pósgraduação, pode deixar embasar-se na discussão ampla dos paradigmas da ciência com suas implicações, no delineamento do projeto pedagógico da educação, da docência e da aprendizagem e na mediação oportuna da articulação metódica das teorias com as práticas desenvolvidas no interior dos estudos sob a forma universitária deles. Sem isto, os próprios conteúdos das disciplinas específicas, sobre os quais, exerce a docência, permaneceriam reduzidos a âmbitos estreitos, privados da capacidade da auto-crítica e da criatividade, necessárias a que se vençam as barreiras do saber já estabelecidas" (MARQUES 1992 ).

A tradição da Faculdade de Saúde Pública, com sua formação multiprofissional e bases multidisciplinares, oferecem as condições básicas 
e essenciais para a formulação dos projetos de capacitação de recursos humanos na área ambiental. No caso de gestão ambiental, o projeto foi enriquecido com a teoria e a práxis da Faculdade de Arquitetura e Urbanismo, gerando um curso de características singulares, constante de saberes destinados a um diálogo interdisciplinar, produtor de uma novo profissional: o gestor ambiental. 


\section{CAPÍTULO 2 - A ESPECIALIZAÇÃO EM GESTÃO AMBIENTAL}

\subsection{A Faculdade de Saúde Pública}

A Faculdade de Saúde Pública da Universidade de São Paulo iniciou suas atividades como "Laboratório de Higiene", criado em 1918 pelo convênio firmado entre o Governo do Estado de São Paulo e a "International Health Board", da Fundação Rockfeller. Tratava-se inicialmente de uma cadeira da Faculdade de Medicina, cujo primeiro titular foi o Professor Samuel Taylor Darling que lançou as bases do ensino de Higiene no Brasil (CANDEIAS 1984). Como professor substituto e primeiro assistente, o Professor Darling contava, respectivamente, com os doutores Geraldo Horácio de Paula Souza e Francisco Borges Vieira, os quais, no período letivo 1919-1920, integraram a primeira turma de diplomados da PUBLIC HEALTH SCHOOL da Universidade John Hopkins, EUA. Cronologicamente a história da faculdade possui os seguintes marcos:

Em 1920, o Professor Darling foi substituído pelo Professor Wilson G. Smillie, que continuou a obra iniciada pelo seu antecessor. Em 1921, o Governo do Estado oficializou o Departamento de Higiene, assumindo todos os seus encargos. Em 1922, regressando o Prof. Smillie aos Estados Unidos, assumiu a direção da cadeira o Professor Geraldo de Paula Souza.

A partir de 1925, o Departamento deixou de ser dependência direta da Faculdade de Medicina, passando a denominar-se "Instituto de Higiene de São Paulo", passando a funcionar em sede própria, à Rua Brigadeiro Tobias $n^{\circ}$. 45. Neste ano, Paula Souza implantou no Instituto de Higiene, o primeiro Curso de Educadores Sanitários, destinado a professores primários. A primeira turma de Médicos Sanitaristas, pelo Instituto, diplomou-se em 1929, depois de fazer, em dois anos, o Curso de Especialização em Higiene e 
Saúde Pública para médicos. Ainda em 1925, Paula Souza e Borges Vieira instalaram o primeiro Centro de Saúde do país, modelo de aprendizado para pessoal de saúde pública, anexo ao Instituto de Higiene.

Em 1926, segundo planos de Paula Souza, iniciou-se a construção do edifício da Faculdade de Higiene, concluída em 1931, quando o Instituto de Higiene foi oficialmente reconhecido como Escola de Higiene e Saúde Pública. Em 1927 o Instituto de Higiene ocupou a nova sede, na Av. Dr. Arnaldo no 715, integrando o Centro Médico de São Paulo. Em 1935 criou-se o Curso de Nutricionistas, com a finalidade de preparar pessoal auxiliar de Saúde Pública no setor de alimentação. Em 1967, este curso foi reestruturado, passando a nível superior, com currículo aprovado pelo Conselho Federal de Educação.

Em 1938, o Instituto de Higiene foi incorporado à Universidade de São Paulo, como uma de suas instituições complementares, subordinado à cadeira de Higiene da Faculdade de Medicina. Em 1941, o Curso de Higiene e Saúde Pública para médicos foi reconhecido pelo Governo Federal, adotando-se para ele o padrão federal de um ano de duração. Em 1945, ano em que, por proposta de Paula Souza e outros, foi criada a Organização Mundial de Saúde, passou o Instituto de Higiene a constituir uma das instituições autônomas de ensino superior da Universidade de São Paulo, sob a denominação de Faculdade de Higiene e Saúde Pública.

Em 1947, foi criado, no município de Araraquara, no Estado de São Paulo, o "Serviço Especial de Saúde", que se constituiu no Centro Rural de Aprendizado da Faculdade de Saúde Pública. 


\subsection{A Faculdade de Saúde Pública e a Pós Graduação Lato-Sensu}

Em 1949, quatro anos após o término da segunda guerra mundial, forma-se a primeira turma de Engenheiros Sanitaristas, e instalou-se o Curso de Especialização em Saúde Pública para Engenheiros. Em 1951, mediante convênio com a "Fundação Kellogg", foi inaugurado o primeiro curso de Administração Hospitalar do país, destinado a médicos e a outros profissionais, interessados neste campo da saúde pública.

Em 1954, com a colaboração da Organização Panamericana de Saúde, teve início o Curso de Especialização em Saúde Pública para Veterinários. Em 1958, mediante convênio entre a Fundação Kellogg, a Organização Panamericana da Saúde e a Universidade de São Paulo, iniciou-se o Curso de Especialização em Saúde Pública para cirurgiões dentistas.

A partir da década de 60, o curso de Educadores Sanitários, passou a Curso de Especialização em Educação para Saúde, para graduados, exigindo desta forma, nível universitário por parte dos alunos. Em 1962, terminada a construção da ala sul, anexa ao edifício da Faculdade, foram para lá transferidos vários Departamentos e Cadeiras, que, assim, tiveram suas instalações ampliadas e melhoradas.

Em 1963, após a aprovação, pela Congregação, do projeto do novo Regulamento da Faculdade, adaptado aos últimos Estatutos da Universidade de São Paulo e que englobava, além da modificação em sua estrutura administrativa, as bases de novo regime de ensino, a Faculdade organizou e instalou profunda reforma didática. Esta foi concretizada com a criação de inúmeras disciplinas e com a ministração de ensino por meio de matérias obrigatórias gerais (comuns a todos os cursos de pós-graduação), matérias obrigatórias especiais (para cada curso em particular) e matérias 
optativas. A reforma didática, aprovada naquele ano através de portaria do Magnífico Reitor, consolidou-se em 1964, quando também obteve a aprovação definitiva do Conselho Universitário.

Ainda em 1964, foi firmado convênio entre a Secretaria da Saúde Pública e da Assistência Social e a Universidade de São Paulo, através da Faculdade de Higiene e Saúde Pública, visando o programa de formação e treinamento de pessoal técnico da Saúde Pública, além de pesquisas científicas e assessoramento técnico.

Em 1969, a Faculdade de Higiene e Saúde Pública passou a denominar-se Faculdade de Saúde Pública, e hoje constitui um dos trinta e dois estabelecimentos de ensino superior que compõem a Universidade de São Paulo, mantidos pelo Governo do Estado.

A partir de 1970, a Faculdade passou a ministrar, com exclusividade na Universidade de São Paulo, o Curso de Pós-graduação em Saúde Pública, níveis de Mestrado e Doutorado. Em 1980, foi transferido para a Faculdade de Saúde Pública, o Curso de Habilitação de Enfermagem em Saúde Pública, anteriormente oferecido pela Escola de Enfermagem da USP.

Acompanhando a evolução da Engenharia Sanitária, e sempre atenta às necessidades de pessoal das entidades responsáveis pela área de Saúde Ambiental, a Faculdade, em 1982, deu mais uma demonstração do seu pioneirismo, e substitui o Curso de Especialização em Saúde Pública para Engenheiros por dois outros Cursos: Especialização em Engenharia Ambiental e Especialização em Engenharia de Saúde Pública. Posteriormente, os cursos foram fundidos, dando origem ao Curso de Especialização em Engenharia Ambiental e em Saúde Pública. Também a partir de 1982, o Curso de Especialização em Saúde Pública passa a ser ministrado em módulos únicos, destinados a qualquer profissional da área da Saúde. 
Em 1988 são criados os cursos de especialização em Engenharia de Controle da Poluição Ambiental e em Engenharia de Saneamento Básico, e, a partir de 1994, objetivando atender a uma demanda mais específica, a Faculdade de Saúde Pública, com a interveniência do NISAM, passou a desenvolver outros cursos de pós graduação lato sensu, em nível de especialização, na área ambiental, ministrados no período noturno e envolvendo outras unidades da Universidade de São Paulo, como a Faculdade de Arquitetura e Urbanismo, para os cursos de Especialização em Gestão Ambiental e a Faculdade de Direito para os cursos de Especialização em Direito Ambiental. Assim, foram criados, adicionalmente aos cursos de Especialização em Engenharia de Controle de Poluição e de Especialização em Engenharia de Saneamento Básico, o curso de Especialização em Controle Ambiental, o curso de Especialização em Educação Ambiental, o curso de Especialização em Gestão Ambiental e o curso de Especialização em Direito Ambiental, que vêm sendo oferecidos até os dias de hoje.

\subsection{Os Núcleos de Apoio às Atividades de Cultura e Extensão (NACE) como agentes de capacitação}

Os NACE são órgãos de integração da USP, instituídos com o objetivo de reunir docentes e especialistas, de um ou mais Departamentos de uma Unidade ou de Unidades e Órgãos da Universidade, em torno de programas culturais ou de extensão, de caráter interdisciplinar e/ou de apoio instrumental à cultura e à extensão. Podem integrar o NACE, além de docentes, especialistas de diferentes órgãos da USP ou de outras instituições, estudantes de graduação e pós-graduação, prática esta bastante incentivada na maior parte dos Núcleos da USP. 


\subsubsection{O Núcleo de Informações em Saúde Ambiental da USP}

O NISAM - Núcleo de Informações em Saúde Ambiental é um NACE vinculado à Pró-Reitoria de Cultura e Extensão Universitária, criado pela Resolução $N^{\circ}$ 3950, baixada pelo Magnífico Reitor da USP, em 22/07/92, publicada e retificada no DOESP, respectivamente nas edições de 28/07/92 e 29/07/92. O NISAM encontra-se instalado na Faculdade de Saúde Pública, desde 28/08/92, com expressa permissão da Unidade. O Regimento Interno do NACE / NISAM foi aprovado pela Resolução da Reitoria da Universidade de São Paulo de $n^{\circ}$. 4185, de 5/7/1995. Em 13 de outubro de 1997 a Comissão de Avaliação de NACE, do Conselho de Cultura e Extensão Universitária, emitiu parecer favorável à renovação do Núcleo, endossado pelo Conselho do Departamento de Saúde Ambiental, em 16/10/97. A Resolução no 4518 de 5/12/97 prorrogou o prazo de funcionamento do NISAM por mais cinco anos.

Participam como membros do NISAM, docentes de diversas Unidades da USP envolvidos em projetos coordenados pelo Núcleo, bem como profissionais de entidades externas à USP.Os integrantes do Conselho Deliberativo do NISAM, bem como os membros do Núcleo são de diversas formações em suas graduações como Engenharia, Medicina, Odontologia, Farmácia - Bioquímica, Biologia, Sociologia, Química, Matemática, Estatística, Física, Arquitetura, Geologia, Geografia, Direito e Serviço Social, entre outras, sendo realçada a necessária multidisciplinaridade.

O NACE/NISAM tem por objetivos: desenvolver estudos e investigações: promover, gerenciar e executar projetos de desenvolvimento de novos conhecimentos para atender demandas da USP ou de outras instituições públicas ou privadas no âmbito da saúde ambiental e assuntos correlatos; treinar e transferir tecnologia: desenvolver cursos, seminários e atividades congêneres, aprofundando o intercâmbio técnico-científico entre instituições 
no país e no exterior, bem como outros eventos objetivando a especialização e atualização de quadros para as diferentes atividades concernentes à saúde ambiental e áreas afins; gerenciar informações: desenvolver e implantar banco de dados sobre saúde ambiental, bem como linhas de trabalho correlatos com a finalidade de propiciar acesso aos diferentes tipos de informação, através do conhecimento das fontes, suas bases de dados, formas de acesso, inclusive funcionando como alternativa para sua obtenção.

De acordo com o deliberado pelo Conselho Deliberativo do NISAM, está prevista uma série de atividades, para ser realizada em um processo contínuo, avaliada a cada dois anos.

No campo de estudos e investigações, o Núcleo atua em conjunto com outras instituições, fornecendo apoio técnico, participando de grupos de trabalho e desenvolvendo assessorias.

No campo do treinamento e transferência de tecnologia, o NISAM promove, apóia, coordena e realiza cursos de Especialização em Gestão Ambiental (CEGA), em Educação Ambiental (CEEA), em Engenharia de Saneamento Básico (CEESB) e em Direito Ambiental (CEDA). O NISAM apóia, promove e executa eventos de caráter técnico-científico sobre questões ambientais tais como seminários internacional e nacional, simpósios, workshops e mesasredondas, além de cursos de aperfeiçoamento, extensão universitária e de curta duração sobre temas de interesse ambiental, tais como: Avaliação de impactos ambientais, Implantação de sistemas de gestão ambiental, auditoria ambiental, eficiência energética e ambiental, análises de risco ambiental, reuso de Águas, legislação ambiental Aplicada e Metodologias de projetos em educação ambiental, ciclos de conferências sobre direito e política ambiental e ciclos de conferências sobre política e gestão ambiental. 
No campo do gerenciamento de informações, dar seqüência às ações em curso destinadas a consolidar e ampliar o PROISA, assim como coordenar a edição de publicações nas áreas de interesse do núcleo. O conjunto de atividades do NACE/NISAM, desde a sua fundação, indica um crescimento da demanda apresentada pela sociedade e demonstra o preenchimento de necessidades e possibilidades de desenvolvimento das questões relacionadas a área ambiental.

A avaliação continuada exercida pelos participantes de cada projeto docentes, profissionais, alunos - sobre os seus objetivos, metodologias e resultados, tem permitido ajustes e avanços em seu desenvolvimento.

A gestão ambiental é imprescindível. Conhecê-la requer conhecimentos específicos dos fenômenos ou processos envolvidos, da utilização de diferentes tecnologias e de resultados que podem ocasionar distintos impactos, negativos ou positivos. Implicações sociais e econômicas, tipos de indústria, processos industriais, tipos de resíduos, efeitos desses no ambiente, distinguindo fauna, flora e o ser humano, planejamento territorial, entre outros, são conhecimentos estruturantes indispensáveis.

A educação ambiental formal, atuando nos diversos graus, se tornou uma necessidade, com sensibilizações por meio de textos especiais que despertem as mentes para a compreensão da problemática, como também para conceberem formas de participação nos processos de gestão ambiental. Não há como administrar o quotidiano sem que todos aqueles que podem contribuir para a qualidade dessa administração e dos respectivos resultados possam participar ativamente. Para tanto devem estar conscientes da amplitude das questões em debate, bem como das possibilidades de diferentes tipos de estratégias, planos e projetos. Necessitam por isto conhecê-los, estudá-los, para poder tomar uma decisão 
consciente. É preciso saber avaliar as conseqüências de diferentes propostas, não só em termos de eficiência, ou seja, de resultados imediatos, mas de eficácia, com impactos ampliados no tempo e no espaço.

Finalmente, a trajetória traçada e trilhada pelo NISAM, até o momento, para o desenvolvimento, o intercâmbio, e a divulgação de projetos e atividades na área de Saúde Ambiental no âmbito da USP, reflete o cuidadoso trabalho multidisciplinar, realizado em bases interdisciplinares, sem o qual não haveria como consolidar e dar credibilidade ao Núcleo. Os envolvimentos e características dos diferentes projetos desenvolvidos, têm exigido um constante trabalho de aglutinação de esforços, base para a consistência necessária ao desenvolvimento da capacitação de recursos humanos, dos projetos editoriais, assim como para a obtenção de financiamento.

A necessidade de capacitação de recursos humanos, por meio de Cursos de Especialização tem ficado cada vez mais evidente. Uma avaliação mais aprofundada do impacto desta capacitação em cursos ministrados pela Faculdade de Saúde Pública, com a coordenação do NISAM, passou a ser imaginada como parte dos objetivos do Núcleo.

\subsection{Os Cursos de Pós Graduação Lato Sensu - Especialização em Gestão Ambiental}

\subsubsection{Antecedentes}

Pode-se remontar a 1986, as primeiras idéias a cerca da criação de um projeto de capacitação na área de gestão ambiental na Faculdade de Saúde Pública. Nesta época entendeu-se que seria interessante começar a preparar de forma estruturada, profissionais para a área de Controle Ambiental e para área de Saneamento Básico, respondendo, 
respectivamente, às necessidades de capacitação em prevenção e controle ambiental, para a CETESB e Secretaria do Meio Ambiente do Estado de São Paulo, e de capacitação em sistemas de abastecimento de água, de esgotamento sanitário e de resíduos sólidos, para a SABESP e correlatas.

Por outro lado, não existia no Estado cursos de especialização nestas áreas, oferecidos no período noturno, uma vez que a maior parte dos profissionais interessados trabalhavam durante o dia. Atuando na CETESB, e ao mesmo tempo, em convivência com o corpo técnico da SABESP, percebeu-se que esses profissionais não tinham como e onde se capacitar. Para atender a esta demanda, a alternativa foi oferecer os cursos no período noturno.

Desta forma, foi proposta então, a realização de dois cursos de especialização: Engenharia de Controle da Poluição Ambiental e Engenharia de Saneamento Básico, estruturados com a experiência da própria Faculdade de Saúde Pública em seus cursos de Engenharia Ambiental e Engenharia em Saúde Pública. A partir desta iniciativa, foram realizados cursos nos anos de 1988, 1989 e 1990.

Entrementes, a Constituição Federal de 1988 reforçou o papel e as responsabilidades dos municípios em questões ligadas ao saneamento e meio ambiente evidenciando a necessidade das prefeituras capacitarem os seus quadros.

A consolidação dos órgãos ambientais dos estados, o processo de municipalização das questões ambientais, por força da Constituição Federal e do Sistema Nacional de Meio Ambiente, e a maior preocupação e consciência das empresas e da sociedade civil, levaram a Faculdade de Saúde Pública a articular-se com a Faculdade de Arquitetura e Urbanismo, para discutir a oportunidade e conveniência de propor e lançar um curso de gestão ambiental. 
Considerando o interesse e necessidade da recém-criada Secretaria Municipal do Verde e do Meio Ambiente de São Paulo em capacitar seus profissionais, é lançado o Curso de Especialização em Gestão Ambiental e, por meio de convênio firmado entre a Secretaria do Verde e do Meio Ambiente e Universidade de São Paulo, foram realizados os quatros primeiros cursos (CEGA1 a CEGA4), oferecidos entre março de 1995 e dezembro de 1996.

2.4.2 Pressupostos assumidos no desenvolvimento e aprovação dos cursos

O desenvolvimento do conteúdo programático dos cursos CEGA (ANEXO 1), bem como a definição de premissas de avaliação docente e discente, foram objeto de conversações envolvendo cerca de 55 professores e profissionais pertencentes à USP e à outras instituições, com atividades relacionadas ao campo da Gestão Ambiental, durante o período de 12 meses. O conjunto de atividades que resultou na aprovação final do curso, pode ser sintetizado nas seguintes ações.

- Formulação dos conteúdos didáticos das disciplinas dos módulos Básico, Cultural e Profissional, em seminários e reuniões realizadas na Faculdade de Arquitetura e Urbanismo e na Faculdade de Saúde Pública;

- Proposição às Unidades; discussão de superposições, engajamento e responsabilidades docente-didáticas, orientação, coordenação, estrutura e desenvolvimento metodológico do Curso, estilo de monografia, com orientadores e apresentação perante banca examinadora; 
- Organização do Projeto, aprovação nos diversos níveis da USP e formulação de acordo de Cooperação entre a Faculdade de Arquitetura e Urbanismo e a Faculdade de Saúde Pública nas suas respectivas congregações, com a presença dos diretores. A participação da FAU, e conseqüentemente de seus docentes, foi fundamental para garantir um conteúdo que relacionasse as questões ambientais com as questões urbanas;

- Identificação do público interessado e negociações institucionais visando viabilização dos Projetos via Convênios, Financiamento direto pelos alunos pagantes, e outros, incluindo atividades de indução de demanda para novos projetos;

- Projetos caracterizados por turmas pequenas, de 30 alunos, trabalhos individuais e em grupo por disciplina, e avaliação por seminários, projetos, exercícios e provas. Incluem os cursos, projetos editoriais e reserva técnica para apoiar novos projetos;

- Projetos contendo equipe de coordenação com atribuições específicas, professores orientadores, professores responsáveis por disciplinas, professores e profissionais envolvidos com o componente editorial, além das características inerentes à sua administração e gerenciamento;

- Coordenadores do Projeto preparam, ao final de cada etapa, avaliação das disciplinas, do curso (no final do $1^{\circ}$ semestre e no final do curso), das monografias, fechamento das notas do Curso, emissão de histórico escolar, cerimônia de conclusão do curso, elaboração de relatórios técnicos de progresso, de final de curso e de prestação de contas; 
- A coordenação do Projeto estrutura, elabora e orienta a produção de textos acadêmicos, para utilização em novos projetos e geração do conhecimento. Diversos textos foram e estão sendo elaborados, e serão trabalhados visando adequação ao projeto do Curso e à divulgação geral;

- A Coordenação do Projeto prepara e encaminha negociações, revisões de programa, equipe e horários, bem como identifica possíveis demandas.

- A Coordenação do Projeto efetua visitas, e discute alternativas com instituições interessadas e seus técnicos, identificando e analisando possibilidades que permitam o estabelecimento de estratégias destinadas ao maior envolvimento e crescimento da USP na geração do conhecimento e na contribuição da Universidade para a capacitação técnica de recursos humanos em Gestão Ambiental inclusive para outras regiões do Estado de São Paulo e do País.

\subsubsection{O processo de seleção e a multidisciplinaridade}

Um dos aspectos mais importantes para construir a multidisciplinaridade, com diferentes profissionais na composição de uma turma, é a realização de processo de seleção que, além das questões de mérito, também esteja atento a uma composição diversificada em termos de formação acadêmica. Especificamente nos cursos de Gestão Ambiental, esta composição é garantida por meio dos seguintes critérios seletivos (Figura 2.1). 
Figura 2.1 - Composição multidisciplinar dos cursos de Gestão Ambiental

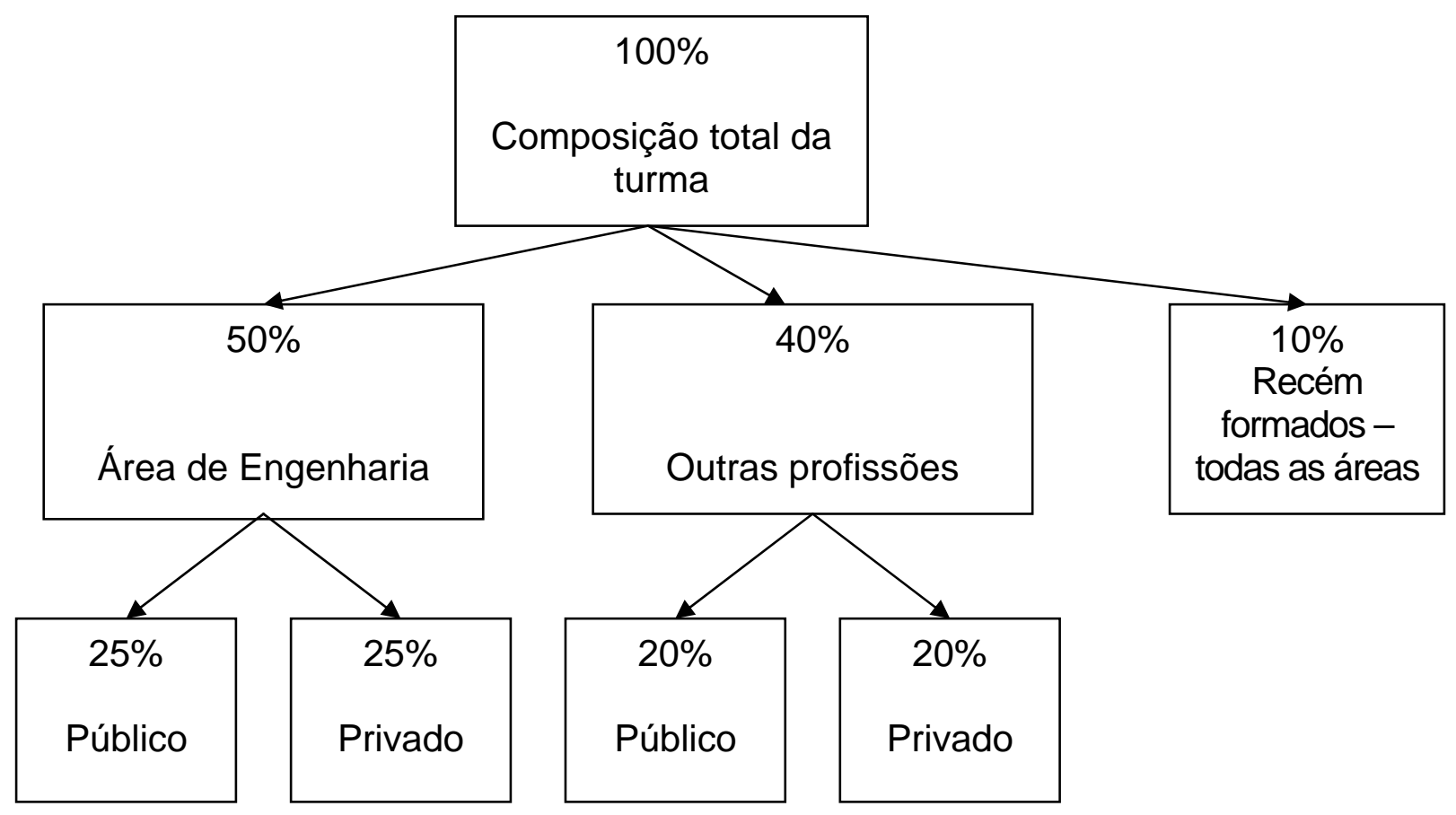

- $50 \%$ das vagas foram direcionadas a profissionais que atuavam na área de Engenharia, sendo $25 \%$ das vagas direcionadas a profissionais da Administração Pública e as demais, para profissionais que atuavam no setor privado;

- 40\% das vagas, para profissionais com formação e/ou atuação em áreas afins à questão ambiental, sendo 20\% das vagas direcionadas a profissionais da Administração Pública, e as demais para profissionais que atuam no setor privado. A seleção deste grupo deve contemplar a multidisciplinaridade;

- $10 \%$ das vagas, devem ser direcionadas a profissionais que tenham concluído os seus cursos de graduação em até um ano antes do início de cada CEGA, e que possuam e demonstrem vínculo e interesse com a área ambiental; 
- Existe em cada curso a possibilidade de 03 vagas, direcionadas para docente, funcionário ou aluno de pós-graduação da USP, que é atendida mediante solicitação escrita, e avaliação por parte da equipe de coordenação.

O número máximo de vagas por curso é de 35 alunos, que são selecionados pela equipe de coordenação por meio de seus curricula vitae, que recebem pontuação segundo os seguintes critérios:

- Trabalhar na área ambiental: 3 pontos;

- Possuir curso de pós-graduação: 3 pontos;

- Possuir experiência didática: 2 pontos;

- Ter publicações em revistas, livros e congressos: 1ponto;

- Ter participação em eventos: 1 ponto.

A partir da pontuação de cada currículo, os candidatos são agrupados atendendo a composição demonstrada na figura 2.1., e em seguida são selecionados os 35 curricula de maior pontuação.

\subsubsection{O processo de avaliação na formação de recursos humanos}

O desenvolvimento dos projetos de capacitação de recursos humanos na área ambiental, da Faculdade de Saúde Pública, prevê a existência de avaliação dos alunos, em cada disciplina, pelos professores; realização de avaliação ao final de cada disciplina, e do curso ao final de cada semestre, pelos alunos. Este trabalho pretende, com base em todas as informações existentes de cada curso de gestão ambiental, e por meio de entrevista com ex-alunos, analisar a evolução e o impacto da atuação profissional dos recursos humanos capacitados. 
"O principal propósito de uma avaliação de sistema é possibilitar o desenvolvimento de políticas públicas na área educacional que contemplem a qualidade do ensino oferecido a todos os alunos, e a igualdade de oportunidades para que alunos possam aprender" (SOUZA 1999).

O exercício profissional requer posicionamentos de reflexão e de investigação, necessários para o desenvolvimento de competências. Estas competências são conquistadas com a prática do questionamento, da fundamentação, da argumentação, do tratamento crítico e criativos da informação. A posição de consumidor passivo de informações não contribui para o aprendizado das práticas de reflexão.

Daí a importância de se trabalhar com avaliação, e possibilitar o controle de como está sendo desenvolvido um curso, uma disciplina, o alunado. Pela avaliação, são identificadas necessidades e prioridades do que está sendo oferecido, devendo ser precedida de cuidadoso planejamento, que vai permitir refletir sobre intenções, e papéis do avaliador, limites de ação e condições para intervenções de ajuste. Assim, por exemplo, se a avaliação do rendimento escolar visa a análise e a proposição de encaminhamentos pedagógicos que contribuam para atingir os objetivos do ensino, o resultado não é a aprovação ou reprovação e sim as propostas que tornem o ensino mais efetivo (SOUZA 1999).

"Avaliação é parte integrante do processo de formação, qualquer que seja o seu nível, e pressupõe quatro funções principais: diagnosticar, aferir o valor dos resultados alcançados considerando os objetivos propostos, servir de referência quanto ao grau de aproximação - distanciamento dos resultados em relação aos objetivos e identificar mudanças de recursos eventualmente necessárias" (ABREU, LARANJEIRA, NOGUEIRA 1999). 
Avaliação envolve informação, que serão analisadas com base nos critérios e objetivos do plano de ensino, e o processo de decisão. Nesse sentido, implica estabelecer como os dados levantados vão permitir o autoconhecimento do aluno e o diagnóstico do ensino oferecido.

É fundamental ter em vista que "nos cursos cujo foco é promover uma formação de alta qualidade, as avaliações não podem apenas visar a coleta de informações sobre o alcance de resultados, mas também deverão procurar identificar as causas das dificuldades e sucessos dos alunos, e promover o desenvolvimento de motivações internas do aluno, de forma a comprometê-lo com o seu próprio desenvolvimento". (SOUZA 1999)

Observando a evolução dos cursos de gestão ambiental, as características dos alunos, o envolvimento de professores e alunos nas atividades acadêmicas e nas monografias de conclusão de curso, e a formação de massa crítica de alunos com série histórica bem definida de profissionais egressos dos cursos, entende-se pertinente e altamente desejável avançar mais no seu processo de avaliação,... "considerado que o propósito de uma avaliação educacional é fornecer subsídios para que os responsáveis pela coordenação e desenvolvimento de ações educativas possam tomar decisões que permitam a aperfeiçoamento de processos e condições de ensino. Dependendo do nível de abrangência das ações educativas e do foco privilegiado em um processo avaliativo, pode-se classificar a avaliação educacional em várias dimensões: avaliação de sistema, avaliação de currículo, avaliação institucional, avaliação de programa e avaliação de rendimento escolar" (SOUZA 1999).

A aplicação do processo avaliativo, planejado quando da implantação dos cursos, e executado sem interrupção em todos, oferece, com sua organização e informações, a possibilidade de confirmar e reforçar acertos, e ajustar ou reformar falhas ou dificuldades em suas várias dimensões, e com isso, contribuir para o aperfeiçoamento dos projetos de cursos da Faculdade de Saúde Pública na área ambiental. 


\subsubsection{O processo de avaliação continuada}

Visando o aprimoramento contínuo e constante, uma das formas adotadas pela equipe de coordenação dos cursos CEGA, foi a realização de avaliações semestrais de cada curso ao longo de sua duração. Cada uma das avaliações consta de duas etapas, sendo a primeira, realizada por meio de questionário preenchido pelos próprios alunos (ANEXO 2), e a segunda, por meio de depoimentos espontâneos a respeito de pontos positivos e negativos de disciplinas, de docentes, do sistema de avaliação, e outros aspectos relacionados à forma e conteúdo do curso.

Tanto a primeira avaliação que ocorre no término do primeiro semestre letivo, como a segunda avaliação, que ocorre na última aula do curso, foram acompanhadas pela coordenação. Os depoimentos e as respostas são registrados na forma em que surgiram e os questionários preenchidos geram uma planilha de resultados, com indicadores estatísticos básicos de compreensão de dados, a saber:

- Média aritmética: Resultado das freqüências absolutas para cada uma das questões;

- Moda: Valor de maior repetitividade, dentre as freqüências absolutas;

- Desvio padrão: Dispersão das freqüências absolutas em torno da média;

- Freqüências absolutas: Quantidade de eventos em cada escala de valor adotada por questão;

- Freqüências relativas: Freqüências absolutas traduzidas em percentuais;

- Histogramas: Figuras ilustrativas.

O processo de avaliação continuada tem sido um instrumento eficaz para a melhoria dos cursos, gerando inclusão de disciplinas, alteração no posicionamento de algumas disciplinas na estrutura curricular do curso, 
substituição ou alteração de docentes, e atendimento às necessidades dos alunos, entre outros.

Desde 1994 ocorreram sucessivas alterações no programa do curso, baseadas nas avaliações discentes de cada disciplina e do curso como um todo (ANEXO 3), e baseado nas avaliações docentes que são realizadas em reuniões plenárias, com a presença dos responsáveis pelas 18 disciplinas do curso, e com a presença parcial dos cerca de 50 docentes envolvidos em cada curso. Estas alterações consideraram o contexto das necessidades que foram emergindo no decorrer dos próprios cursos, e resultaram em três intervenções que elevaram a carga horária total do curso CEGA. A tabela 2.1 a seguir ilustra estas alterações.

Tabela 2.1 - Alterações sofridas nos cursos CEGA de 1995 a 2001

\begin{tabular}{|c|c|c|c|}
\hline & $\begin{array}{c}\text { PERÍODO } \\
\text { DE } \\
\text { VIGÊNCIA }\end{array}$ & $\begin{array}{c}\text { CARGA } \\
\text { HORÁRIA } \\
\text { TOTAL }\end{array}$ & ALTERAÇÃO SOFRIDA \\
\hline 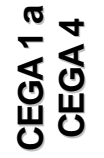 & $\begin{array}{r}1995 \text { a } \\
1996\end{array}$ & 450 horas & - Nenhuma \\
\hline 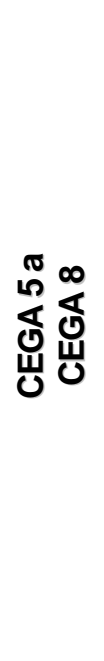 & $\begin{array}{r}1997 \text { a } \\
1999\end{array}$ & 476 horas & $\begin{array}{l}\text { - Introdução da disciplina "Abertura e } \\
\text { Integração" (12h) } \\
\text { - Elevação da carga horária da } \\
\text { disciplina "Controle Ambiental IV" (28 } \\
\text { h) } \\
\text { - Elevação da carga horária da } \\
\text { disciplina "Sistemas de Integração } \\
\text { Ambiental" (24h) } \\
\text { - Elevação da carga horária da } \\
\text { disciplina "Auditoria Ambiental" } \\
\text { (32h) } \\
\text { - Elevação da carga horária da } \\
\text { disciplina "Seminários sobre Gestão } \\
\text { Ambiental" (24h) }\end{array}$ \\
\hline 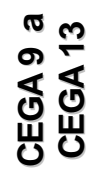 & $\begin{array}{r}1999 a \\
2001\end{array}$ & 500 horas & $\begin{array}{l}\text { - Introdução da disciplina "Direito } \\
\text { Ambiental Aplicado" (24h) }\end{array}$ \\
\hline
\end{tabular}


A análise da tabela 2.1 demonstra a atualização efetuada no curso ao longo dos últimos 8 anos, visando uma adequação cada vez maior com o momento histórico e as necessidades profissionais do futuro gestor ambiental.

Esta necessidade gerou a inclusão da disciplina "Abertura e Integração" à partir do CEGA 5, inclusive, e da disciplina "Direito Ambiental Aplicado" a partir do CEGA 9, inclusive. No momento o curso atingiu o limite máximo de carga horária permitida e que possa ser administrada no período de 1 ano, não existindo portanto possibilidade de inclusão de novas disciplinas que gerem acréscimo de carga horária.

Outros ajustes e remanejo interno de disciplinas foram realizados, visando atender às solicitações dos alunos, entre eles: o deslocamento da disciplina "Linguagem e Percepção Ambiental" do segundo semestre para o primeiro semestre e a inclusão do conteúdo" Metodologia do Trabalho Científico" à partir do CEGA 5, inclusive.

Se as futuras avaliações discentes ou plenárias docentes identificarem a necessidade de novos conteúdos, será necessário promover algum tipo de remanejo interno para adequar o curso às necessidades da área. Caso haja extrema necessidade de aumento de carga horária, gerada por necessidade de aumento de conteúdo, o curso terá que extrapolar o período de 12 meses letivos, acarretando inclusive alteração nos custos vigentes.

\subsubsection{A estrutura curricular atual}

Após 7 anos, de consecutivas avaliações, e após a inclusão dos conteúdos citados anteriormente, o Curso de Especialização em Gestão Ambiental apresenta uma estrutura curricular e carga horária dividida em três módulos. O módulo 1 - Básico - Fundamentação do Controle Ambiental apresenta os conteúdos de Saúde e Ambiente, incluindo a questão do ar, da água, do solo e das áreas verdes. O módulo 2 - Cultural - Fundamentação Sócio-Político 
Cultural do Meio Ambiente, apresenta conteúdos multidisciplinares e importantes para a compreensão da área ambiental. O módulo 3 Profissional: Planejamento e Gestão Ambiental trata da formação técnica e do controle preventivo e corretivo das ações. O quadro 2.1 a seguir apresenta a atual estrutura curricular com as correspondentes cargas horárias, válidas até o CEGA 17.

Quadro 2.1 - Estrutura curricular CEGA - 9 ao CEGA - 13

\begin{tabular}{ll}
\hline CONTEÚDO & CARGA HORÁRIA
\end{tabular}

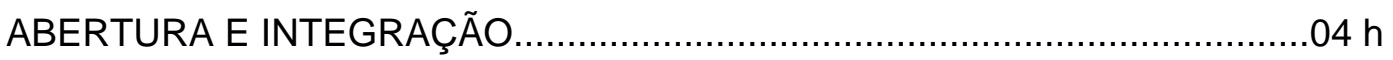

I. MÓDULO BÁSICO: FUNDAMENTAÇÃO DO CONTROLE AMBIENTAL..168h

1. Saneamento Ambiental e Ecologia Aplicada......................................... $24 \mathrm{~h}$

2. Controle Ambiental I.............................................................................28h

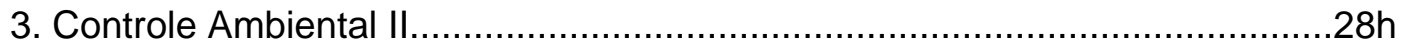

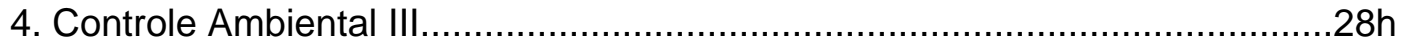

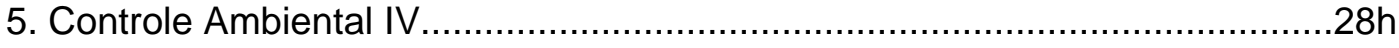

6. Sistemas de Integração Ambiental.......................................................24h

7. Orientação Bibliográfica Aplicada...........................................................

II. MÓDULO CULTURAL: FUNDAMENTAÇÃO SÓCIO- POLÍTICO CULTURAL DO MEIO AMBIENTE..........................................................136h

8. Linguagem e Percepção Ambiental....................................................24h

9. Fundamentos de Saúde Pública.........................................................28h

10. Fundamentos de Educação Ambiental.................................................24h

11. Política e Gestão Ambiental......................................................................

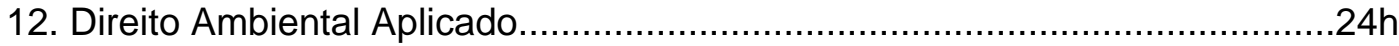

III. MÓDULO PROFISSIONAL: PLANEJAMENTO E GESTÃO AMBIENTAL

13. Desenvolvimento Urbano e Administração Pública....................................32h

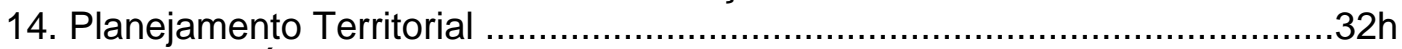

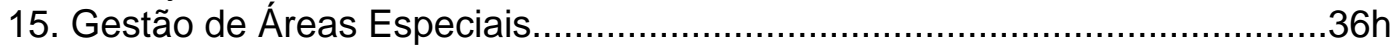

16. Avaliação de Impacto Ambiental............................................................

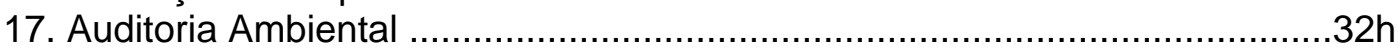

18. Seminário sobre Gestão Ambiental.....................................................24h

CARGA HORÁRIA TOTAL ................................................................500 $\mathrm{h}$ 
No momento está sendo oferecido o curso CEGA 17, que será concluído em dezembro de 2002. Os resultados desta tese, certamente produzirão uma discussão fundamentada para revisitar conteúdos programáticos de disciplinas, visando eventuais ajustes para os próximos cursos.

\subsection{Justificativa da Escolha do Tema}

A concentração populacional em áreas urbanas, mérito das responsabilidades e da consciência dos municípios e das empresas, a ocupação desordenada do território, a desarticulação institucional, a falta de uma gestão eficiente, entre outros aspectos, têm trazido conseqüências desastrosas para o meio ambiente, afetando a fauna e flora e também o elemento humano. Com o passar do tempo, esses problemas tornaram-se comuns às áreas urbanas e rurais, pois a ação antrópica não encontrou limites, levando seus impactos ao ambiente, poluindo as águas, o ar e o solo.

À medida que a questão ambiental vai se agravando, a cobrança da sociedade vem aumentando, com o gradual crescimento das responsabilidades e da consciência dos municípios e das empresas, o que aumenta a necessidade de profissionais atuando em equipe, com características multidisciplinares e atuação interdiciplinar, devidamente preparados para enfrentar essa problemática. Criou-se então uma demanda por profissionais capacitados a entender e intervir nesta questão, resultando numa nova exigência por cursos de capacitação na área ambiental, em particular em Gestão Ambiental.

Em face dessa realidade, a Universidade de São Paulo vem oferecendo cursos de pós graduação lato-sensu, em nível de especialização, voltados para o atendimento dessa necessidade, que tem crescido de maneira constante ao longo do tempo. Assim, desde 1995, a Faculdade de Saúde Pública tem desenvolvido, em conjunto com a Faculdade de Arquitetura e Urbanismo, o Curso de Especialização em Gestão Ambiental (CEGA). Este curso, de pós- 
graduação Lato Sensu, focaliza, com maior atenção, a gestão do ambiente urbano e rural, sem a qual, legislação, normas e outros atos de governo, não conseguem ser articulados e executados, levando o poder público à inação, ou mesmo à sobreposição de ações, com desgaste para a máquina administrativa, desperdício de gastos, ineficiência, e danos ao ambiente e à população. Percebe-se então, a importância da dimensão assumida pela relação: educação, saúde e ambiente, e como este conjunto deve fazer parte das políticas urbanas, no âmbito das diferentes esferas de governo.

Uma referência teórica que se destaca nas questões de política e gestão ambiental é a Agenda 21, que ao lado de outros estudos, enfatizam a necessidade de associar a dimensão ambiental às políticas públicas, entre as quais as urbanas, de recursos hídricos, de educação ambiental e de saúde, respeitadas as competências constitucionais de governo; promove também o desenvolvimento sustentável dos assentamentos humanos, bem como incorpora ainda, o conceito de sustentabilidade ao desenvolvimento do país (MMA 2000; MMA/PNUD 2000).

Este desenvolvimento, por sua vez, para ser sustentável, exige que o uso dos recursos naturais seja racional, para que estes não se esgotem, inviabilizando a vida humana. Este desenvolvimento fica, portanto, condicionado à possibilidade de realimentação dos recursos naturais e distribuição justa dos benefícios deles decorrentes. Para tanto, deve basear-se num processo de planejamento participativo, que envolva toda a sociedade.

Assim é que o CEGA, voltando-se para essas questões, objetiva a capacitação profissional, partindo do princípio de que esses profissionais, cada vez mais, tendem a atuar em equipes e a desenvolver trabalhos de caráter multidisciplinar e dentro de perspectiva interdisciplinar, cujas propostas, constituídas de planos, programas e projetos, devem se consubstanciar numa nova forma de gestão ambiental, que promova a sustentabilidade. 
Faz-se necessário também, uma avaliação sistemática da proposta do conteúdo multidisciplinar que vem sendo oferecido e do impacto deste conteúdo em um corpo de profissionais com formações bastante variadas e atuando nas mais diversas áreas de ação ambiental.

\subsection{Hipóteses e Objetivos}

Os Cursos de Especialização em Gestão Ambiental - CEGA, vêm preparando profissionais, desde 1995, para trabalhar com a questão da gestão ambiental, de forma a contribuir nas tarefas de prevenção, controle, preservação e recuperação ambiental de suas áreas regionais de atuação. Para conseguir este propósito, o Curso foi planejado para tratar os temas que envolvem a questão, em 3 módulos distintos. Os diversos módulos oferecem subsídios para o desenvolvimento de ações junto ao meio ambiente e, abordam estratégias, métodos e técnicas a serem utilizadas na prevenção e controle da qualidade ambiental. Desse modo os alunos têm a oportunidade de integrar a teoria à realidade.

Esta pesquisa parte portanto, neste contexto, das seguintes hipóteses:

- Os profissionais capacitados nos Cursos de Especialização em Gestão Ambiental, CEGA, da Faculdade de Saúde Pública da Universidade de São Paulo, vêm contribuindo para suprir parte da demanda por esta especialidade em suas áreas de atuação regional;

- Os profissionais capacitados nos Cursos de Especialização em Gestão Ambiental, CEGA, da Faculdade de Saúde Pública da Universidade de São Paulo, estão atuando em situações que envolvem problemática ambiental em suas áreas de atuação e, desta forma, vêm contribuindo para a supressão ou redução dos problemas ambientais em suas regiões. 


\subsubsection{Objetivo Geral}

- Avaliar o impacto da atuação profissional multidisciplinar de recursos humanos, capacitados pelos cursos de especialização em Gestão Ambiental - CEGAs da Faculdade de Saúde Pública e da Faculdade de Arquitetura e Urbanismo da Universidade de São Paulo.

\subsubsection{Objetivos Específicos}

- Caracterizar o perfil dos alunos dos cursos de Gestão Ambiental com relação aos seguintes aspectos pessoais e profissionais: formação inicial, gênero, cidade de atuação profissional, setor de atuação profissional - Público, Privado, ONGs, engajamento profissional na área ambiental, tempo de conclusão de curso e temas de monografias desenvolvidas.

- Conhecer a opinião dos alunos com relação a sua atuação no mercado profissional no momento atual à luz da capacitação realizada na área de gestão ambiental.

- Avaliar as mudanças e os impactos ocorridos na vida profissional dos exalunos, após uma capacitação multidisciplinar, com diálogo interdisciplinar, realizada na área de gestão ambiental. 


\section{CAPÍTULO 3 - METODOLOGIA}

\subsection{Considerações preliminares}

Para se atingir os objetivos desta pesquisa, a metodologia adotada foi subdividida em duas etapas, a saber:

$1^{\text {a }}$. Etapa - Levantamento das características dos 408 ex-alunos matriculados nos 13 Cursos de Pós Graduação Lato Sensu - Especialização em Gestão Ambiental da Faculdade de Saúde Pública e Faculdade de Arquitetura e Urbanismo da Universidade de São Paulo.

$2^{\mathrm{a}}$. Etapa - Aplicação de roteiro de entrevista em amostra representativa dos ex-alunos matriculados nos 13 Cursos de Pós Graduação Lato Sensu Especialização em Gestão Ambiental, e avaliação do impacto ocorrido na vida profissional destes alunos, após a conclusão do curso.

\section{2 $\quad 1^{\text {a }}$. Etapa da pesquisa}

A análise correspondente à esta etapa foi feita inicialmente individualmente, para cada um dos 13 cursos e posteriormente estes indicadores foram analisados de forma agregada apontando tendências e traçando o perfil típico e predominante dos profissionais envolvidos. Para tanto foram analisadas as fichas de inscrição de todos os alunos $(n=408)$, assim como os temas dos trabalhos de conclusão de curso desenvolvidos. As tabelas contendo os dados cadastrais dos ex-alunos dos cursos CEGA 1 a CEGA 13, encontram-se no anexo 6 desta tese.

Os dados levantados e extraídos das fichas de matricula para os 408 alunos dos cursos CEGA 1 a 13, no período de fevereiro de 1995 a dezembro de 2001 foram os seguintes: 
- Formação profissional

- Gênero

- Local de atuação profissional

- Atuação ou não na área ambiental

- Setor de atuação profissional (Público, Privado ou ONG)

- Tempo de formado

- Temas de trabalho de conclusão de final de curso desenvolvidos pelos alunos

\section{$3.3 \quad 2^{\mathrm{a}}$. Etapa da pesquisa}

3.3.1. Universo da pesquisa e amostra representativa

O universo desta pesquisa foi composto pelo somatório de todos os alunos matriculados nos 13 cursos CEGA e totalizou 408 alunos, conforme demonstrado na tabela 3.1., a seguir:

Tabela 3.1 - Distribuição dos ex-alunos dos CEGAs

\begin{tabular}{cccc}
\hline Curso & Total & S. Paulo $^{(1)}$ & Ext. $^{(2)}$ \\
\hline 1 & 31 & 31 & 0 \\
2 & 31 & 29 & 2 \\
3 & 31 & 30 & 1 \\
4 & 31 & 2 & 29 \\
5 & 29 & 29 & 0 \\
6 & 26 & 18 & 8 \\
7 & 34 & 29 & 5 \\
8 & 38 & 32 & 6 \\
9 & 34 & 32 & 2 \\
10 & 34 & 23 & 11 \\
11 & 38 & 0 & 38 \\
12 & 23 & 13 & 10 \\
13 & 28 & 19 & 9 \\
Total & 408 & 287 & 121 \\
(\%) & $100 \%$ & $70 \%$ & $30 \%$ \\
\hline
\end{tabular}

(1) Alunos oriundos da cidade de São Paulo

(2) Alunos oriundos de outras localidades 
Considerando os objetivos desta pesquisa optou-se por utilizar procedimentos da estatística descritiva cuja meta é prover uma representação de dados que possibilite descrever os resultados obtidos na forma de tabelas, de figuras ou de números (ORNSTEIN e ROMÉRO, 1995). Na definição amostral no âmbito da estatística descritiva foram consideradas as seguintes variáveis:

๑ Variável normal padronizada - O valor da variável normal padronizada (za/2) é função direta dos intervalos de confiança da pesquisa. Nesta pesquisa adotou-se o valor 2 que situa-se em uma posição intermediária entre $z \alpha / 2=3$ e $z \alpha / 2=1$.

๑ Intervalo de confiança: 95,5

口 $\quad \mathrm{e}=10 \%$ (Margem de erro). Para um mesmo universo, a margem de erro é fator determinante no valor da amostra representativa.

口 $p=50 \%$ ou 0,5 (proporção de elementos com a característica estudada)

ㅁ $q=1-p \Rightarrow 0,5$

a Universo finito $=408$ indivíduos. Para um mesmo universo, a margem de erro é fator determinante no valor da amostra representativa.

Para o cálculo da amostra adotou-se a equação a seguir:

$$
\mathrm{n}=\frac{(z \alpha / 2)^{2} \times p \times q}{\mathrm{e}^{2}}
$$


A aplicação da fórmula anterior, utilizando procedimentos da estatística descritiva resultou em uma amostra de 82 alunos. Buscando reduzir a margem de erro para valores situados entre 7 e 8\% foi necessário elevar a amostra representativa para valores próximos a 150 alunos, que se tornou a amostra alvo.

A margem de erro (e) foi obtida pela equação:

$$
E=\sqrt{ } 1 / n
$$

onde $e=\sqrt{ } 1 / 150 \quad \Rightarrow e=\sqrt{ } 0,006 \quad \Rightarrow 0,07 \quad \Rightarrow 7 \%$

Desta forma, considerando a amostra representativa alvo de 150 ex-alunos e um intervalo de confiança de 95,5\%, a margem de erro resultante é de $7 \%$. O critério escolhido para a determinação de 150 indivíduos em um universo de 408, foi o sorteio aleatório de 230 indivíduos, ou seja, cerca de 80 além do valor amostral, visando absorver os possíveis alunos não encontrados em suas residências ou locais de trabalho, para participar da pesquisa. Dos 230 indivíduos sorteados, 143 responderam às entrevistas, resultando, portanto em uma margem de erro real de $8 \%$.

A amostra definida nesta pesquisa é do tipo probabilística aleatória simples, tendo em vista que cada elemento da população tem uma chance conhecida e diferente de zero, de ser selecionado para compô-la (MATTAR 2000) e tendo em vista também que a amostra é constituída de elementos selecionados por processos aleatórios e não pela vontade do pesquisador.

\subsubsection{Método adotado no levantamento de dados}

Para a obtenção de dados sobre o impacto individual dos profissionais capacitados na área de Gestão Ambiental, as seguintes técnicas poderiam 
ser utilizadas, a saber: questionários enviados pelo correio; questionários aplicados em grupo, entrevistas realizadas face a face com roteiro de entrevistas ou não; questionários aplicados face a face; questionários ou roteiro de entrevistas, aplicadas por telefone (KIDDER 1981). Cada uma delas possui vantagens e desvantagens.

Os questionários enviados pelo correio possuem baixo índice de retorno, ou seja, entre 3 e $5 \%$ e para esta pesquisa e para o universo existente, um retorno desta ordem não viabilizaria a amostra desejada. Os questionários aplicados em grupo e as entrevistas/questionários aplicados face a face, tornam-se inviáveis, tendo em vista a dificuldade de reunir os ex-alunos do curso, devido ao fato de que muitos deles residem atualmente fora da cidade de São Paulo.

As entrevistas realizadas por telefone tornam-se opções bastante interessantes pelos seguintes motivos: (1) possibilidade de encontrar parte dos ex-alunos, sem envolver o deslocamento físico do entrevistador; (2) possibilidade de retornar o contato em nova oportunidade; (3) rapidez de resposta e conseqüente análise dos dados e; (4) possibilidade de realização de entrevistas adicionais que seriam economicamente enviáveis em outros casos.

\subsubsection{Elaboração do pré-teste}

De acordo com os objetivos da pesquisa para a formulação das questões do roteiro de entrevista, houve a preocupação e o cuidado de não induzir as respostas, não aumentar o tempo previsto para cada respondente e garantir a qualidade das respostas por parte do entrevistado. 
3.3.4 A Aplicação do pré-teste, análise e elaboração do roteiro de entrevista definitivo.

O pré-teste foi aplicado em $10 \%$ da amostra representativa pretendida, portanto 15 ex-alunos dos cursos CEGAs. O objetivo do pré-teste foi aferir a aplicabilidade e relevância das questões formuladas, bem como avaliar as respostas com relação à terminologia adotada; compreensão daquilo que estava sendo perguntado e tempo médio necessário para o preenchimento do mesmo.

A aplicação do pré-teste resultou nas seguintes considerações:

- O tempo de resposta variou de $8^{\prime}$ a $15^{\prime}$ minutos por roteiro de entrevista aplicado. Este dado foi considerado satisfatório, e a partir dele, foi estimado o tempo total de aplicação dos 150 roteiros;

- Foi incluída no início do roteiro de entrevistas, uma observação, dando a possibilidade ao respondente de não participar da pesquisa e desta forma, não responder ao roteiro;

- Foi incluída no início do roteiro de entrevistas, uma explicação referente ao projeto de pesquisa em questão, e a importância do seu preenchimento para o aprimoramento dos cursos CEGA;

- Na questão 1.1, foi introduzida a opção outra possibilidade de trabalho;

- A questão 1.2 foi sub-dividida em duas questões abordando na primeira, a mudança na forma de pensamento do entrevistado após cursar o CEGA e na segunda, a atuação do entrevistado no local de trabalho após cursar o CEGA; 
- A palavra empresa foi substituída pela palavra instituição;

- Na questão 1.5.1, foi inserida a opção: atuação profissional como assessor ou consultor;

- Na questão 4, foi inserida a área do Direito Ambiental como outra possibilidade de atuação;

- A questão 5 foi sub-dividida em duas questões, abordando na primeira sugestões sobre conteúdos que poderiam ser aprofundados e na segunda, conteúdos que poderiam ser adicionados;

- Foi acrescentada uma questão de número 6, possibilitando ao aluno efetuar comentários adicionais;

- Por fim, a equipe de pesquisa decidiu que ao término da entrevista o aluno deveria ser informado sobre um número telefônico, para esclarecimentos e dúvidas, quanto a pesquisa e seus objetivos.

O Roteiro de Entrevistas adotado nesta pesquisa encontra-se no ANEXO 5.

\subsubsection{Aplicação do roteiro de entrevistas}

As entrevistas foram realizadas por uma equipe formada por três pesquisadores/alunos de pós-graduação, que receberam treinamento específico quanto ao preenchimento do mesmo. O prazo máximo definido para esta tarefa foi de 15 dias corridos, incluindo finais de semana no horário entre 9:00 e 20:00 horas, pois muitos ex-alunos seriam encontrados em suas residências no período noturno e/ou nos finais de semana. Cada pesquisador utilizou uma linha telefônica e recebeu cerca de 50 roteiros de 
entrevistas a serem preenchidos, bem como recebeu uma explicação por escrito, de como a entrevista deveria ser conduzida e aplicada.

Optou-se pela aplicação do roteiro de entrevistas no menor tempo possível visando reduzir a possibilidade de interferências externas, de caráter político, ou eleitoral, ou mesmo relacionado à copa do mundo, entre outras, que poderiam influenciar as respostas. Desta forma, aplicando o roteiro de entrevistas no menor prazo de tempo possível, poderíamos garantir que todos os entrevistados viviam a mesma conjuntura.

\subsubsection{Análise dos dados}

Para a etapa de análise dos dados quantitativos, foram desenvolvidas planilhas eletrônicas no programa MICROSOFT EXCEL. As respostas das 143 entrevistas foram digitadas em arquivos separados do programa que gerou os histogramas correspondentes. As questões do tipo qualitativas foram avaliadas separadamente e agrupadas por tipo de argumento e similaridade de respostas.

\subsection{Resultados e discussão}

Os resultados discutidos nesta etapa encontram-se no capítulo 4 desta tese - Resultados e Discussão. Neste momento os resultados foram analisados e discutidos considerando os perfis dos alunos e seus momentos atuais na profissão e no mercado de trabalho. Neste capítulo todos estes aspectos foram abordados com maior profundidade. Nesta etapa foram também comparados os resultados da $1^{\text {a }}$ Etapa da pesquisa, que analisa 0 levantamento e a tabulação dos dados do universo de 408 ex-alunos avaliados quando do inicio do curso, com a $2^{\mathrm{a}}$. Etapa da pesquisa que realiza e avalia o levantamento e tabulação dos dados da amostra representativa da mesma população $(n=143)$ após a conclusão do curso. 


\subsection{Conclusões}

A etapa de conclusões, discutida no capítulo 5, analisa fundamentalmente dois aspectos. O primeiro, relativo aos objetivos e a forma como eles foram atingidos e o segundo, relativo a comprovação ou não das hipóteses levantadas. 


\section{CAPÍTULO 4 - RESULTADOS E DISCUSSÃO}

\subsection{Considerações preliminares}

Este capítulo apresenta os resultados da primeira etapa da pesquisa, que avaliou as características dos ex-alunos matriculados nos Cursos de Especialização Lato-Sensu em Gestão Ambiental, desde o CEGA - 1 em março de 1995 até o CEGA - 13, em dezembro de 2001. Este capítulo apresenta também os resultados da segunda etapa da pesquisa, que analisou os resultados das entrevistas realizadas com os 143 ex-alunos.

\subsection{Análise dos resultados - $1^{\mathrm{a}}$. Etapa da pesquisa}

As tabelas e as figuras apontaram os indicadores estatísticos do corpo discente dos 13 Cursos de Especialização em Gestão Ambiental, objeto de análise nesta tese. A análise foi feita individualmente por curso e posteriormente estes indicadores foram analisados de forma agregada, apontando tendências e os perfis para os profissionais envolvidos. Os dados dos ex-alunos do CEGA 1 ao CEGA 13, encontram-se no ANEXO 6. 
CEGA - 1

Início: março de 1995

Término: dezembro de 1995

Quantidade de alunos matriculados: 31 alunos

Figura 4.1 - Número de alunos de acordo com a formação profissional (CEGA 1)

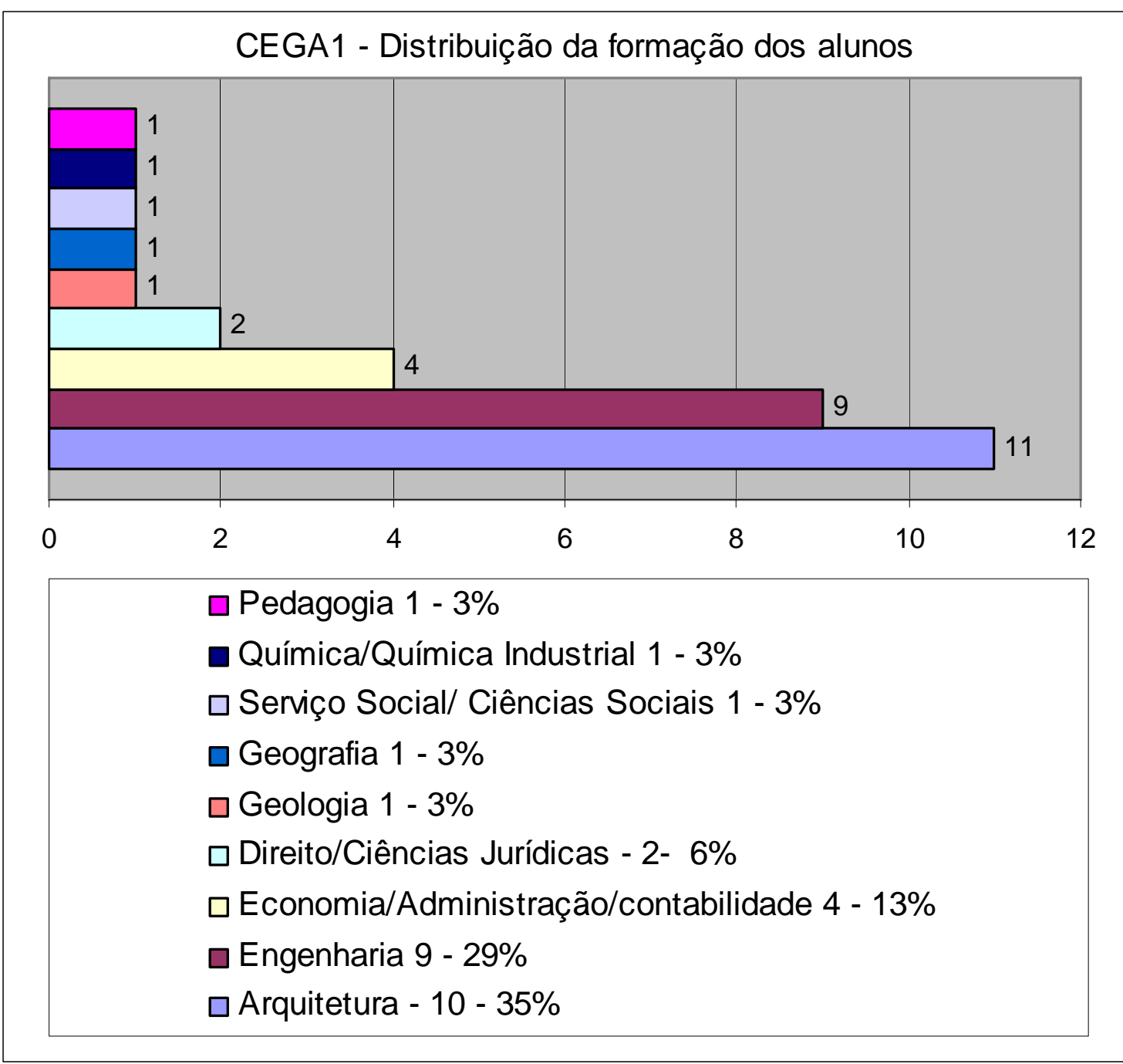


Figura 4.2 - Alunos por gênero (CEGA 1)

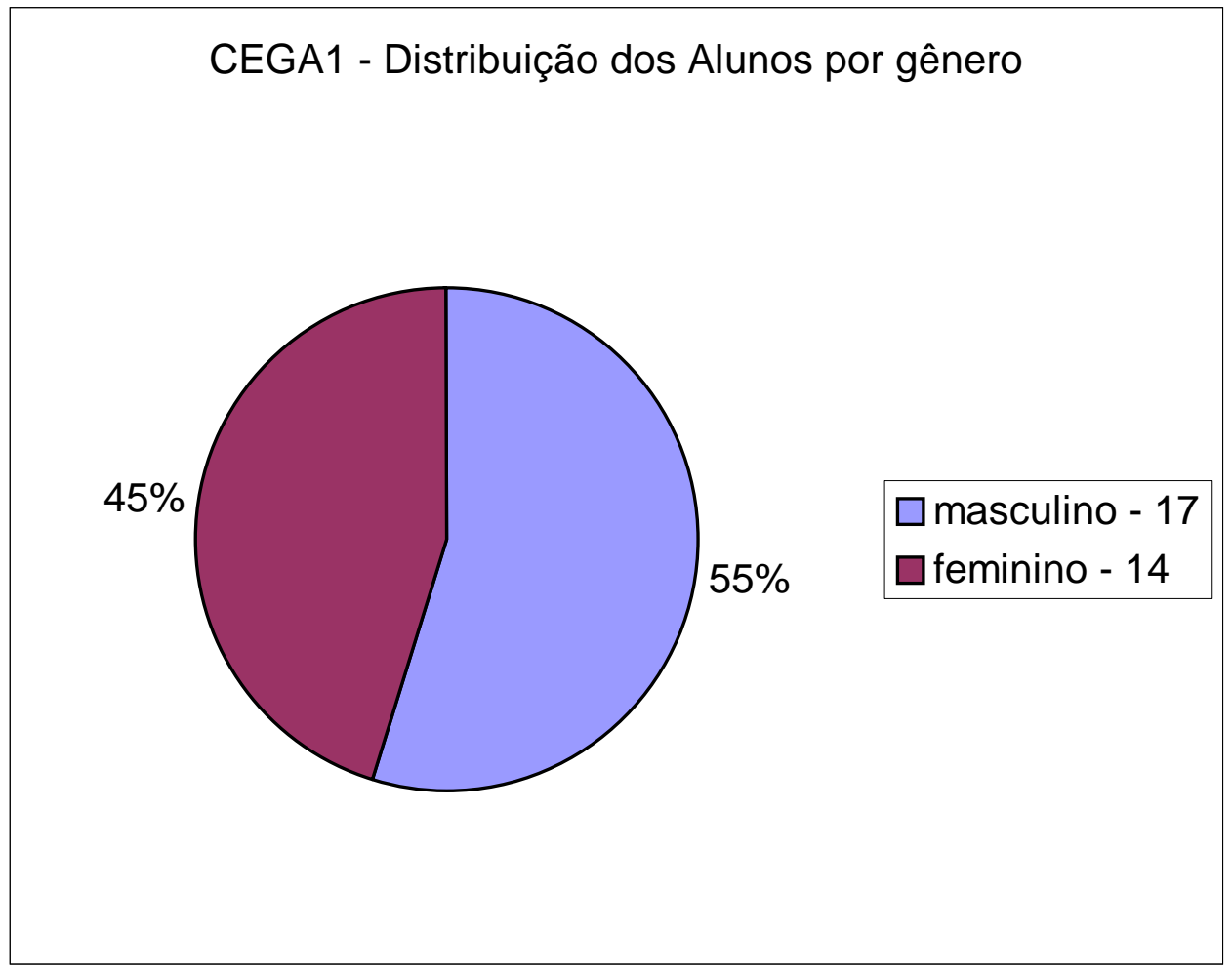

O curso foi composto basicamente por profissionais das áreas de arquitetura ( $n=10)$, e engenharia $(n=9)$, totalizando $64 \%$ dos alunos matriculados (figura 4.1). Todos os alunos atuavam na cidade de São Paulo, na área ambiental e no setor público. Os alunos (63\%) tinham entre 08 e 17 anos de formados, quando do início do curso em março de 1995. O gênero predominante foi o masculino, 55\%, conforme figura 4.2 . 


\section{CEGA - 2}

Início: agosto de 1995

Término: junho de 1996

Quantidade de alunos matriculados: 31 alunos

Figura 4.3 - Número de alunos de acordo com a formação profissional (CEGA 2)

CEGA 2 - Distribuição da formação dos alunos

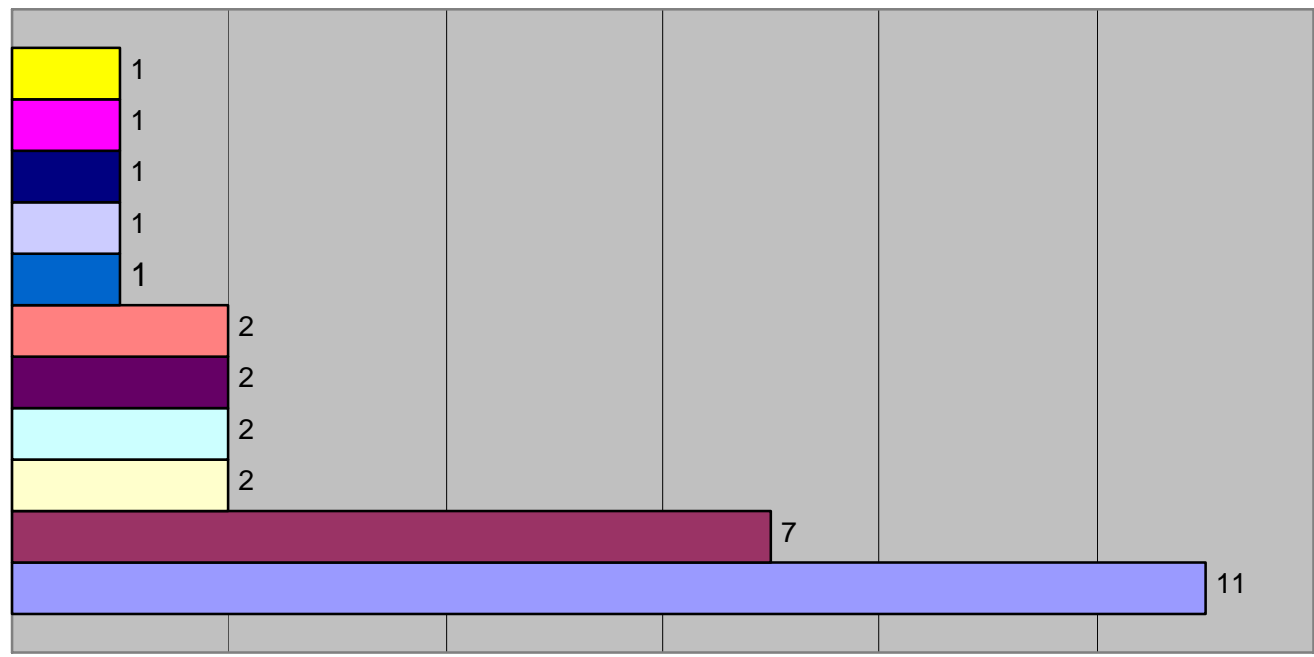

$\square$ Direito/Ciências Jurídicas 1 - 3\%

$\square$ Agronomia 1 - 3\%

- Educação Artística 1 - 3\%

$\square$ Biologia 1 - 3\%

Filosofia 1 - 3\%

$\square$ Letras 1 - 6\%

- Serviço Social/ Ciências Sociais 2 - 6\%

$\square$ Geógrafia 2 - 6\%

$\square$ Economia/Administração/contabilidade 2 - 6\%

$\square$ Engenharia 7- 23\%

$\square$ Arquitetura 11 - 35\% 
Figura 4.4 -Alunos por gênero (CEGA 2)

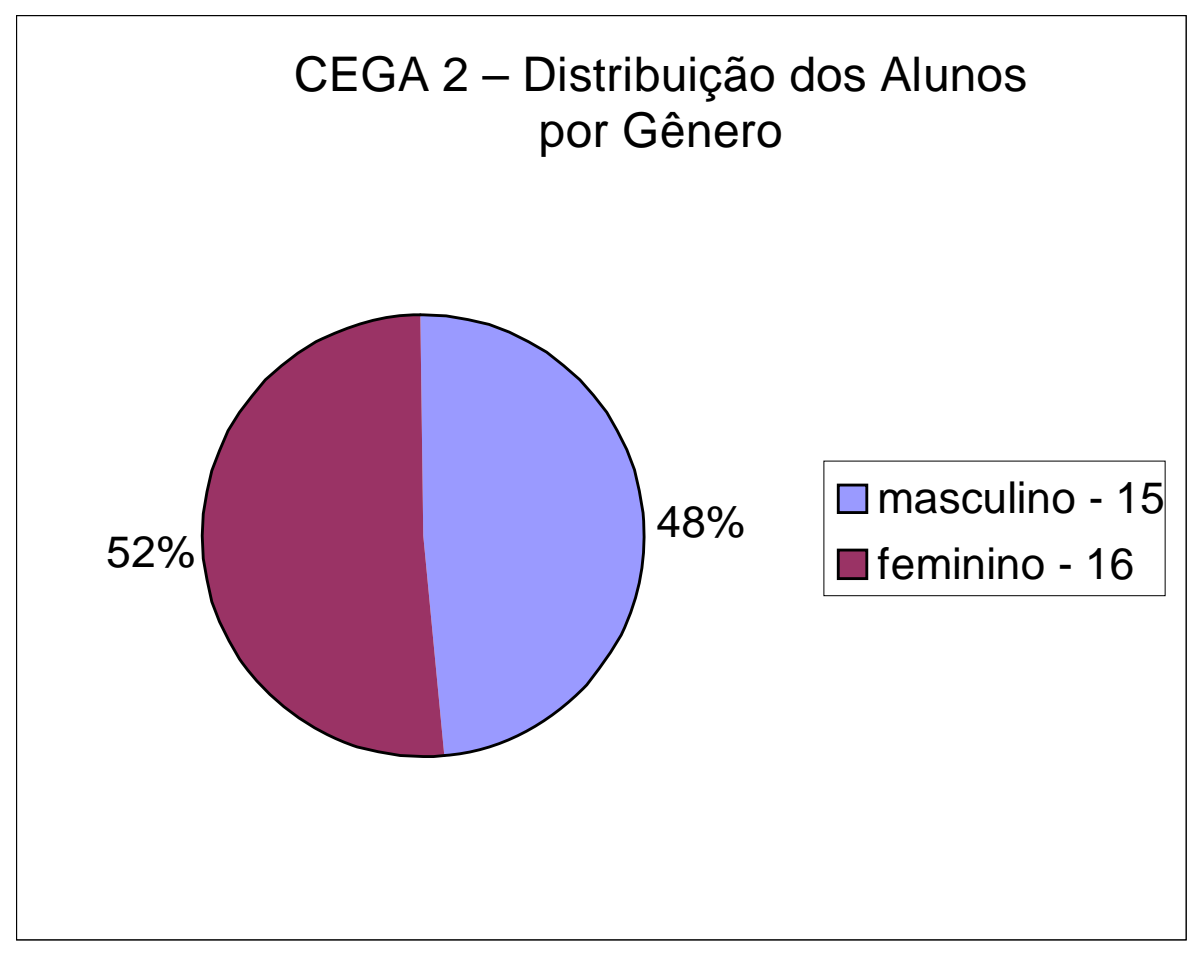

O curso foi composto basicamente por profissionais das áreas de arquitetura $(n=11)$ e engenharia $(n=7)$, totalizando $58 \%$ dos alunos matriculados (Figura 4.3). Com relação ao local de atuação constatou-se que 93\% dos alunos atuavam na cidade de São Paulo, quando iniciaram o curso. Todos os alunos eram do setor público e somente $6 \%$ dos alunos não trabalhavam na área ambiental. De acordo com a figura 4.4, o gênero predominante foi 0 feminino (52\%). 
CEGA - 3

Início: fevereiro de 1996

Término: dezembro de 1996

Quantidade de alunos matriculados: 31 alunos

Figura 4.5 - Número de alunos de acordo com a formação profissional (CEGA 3)

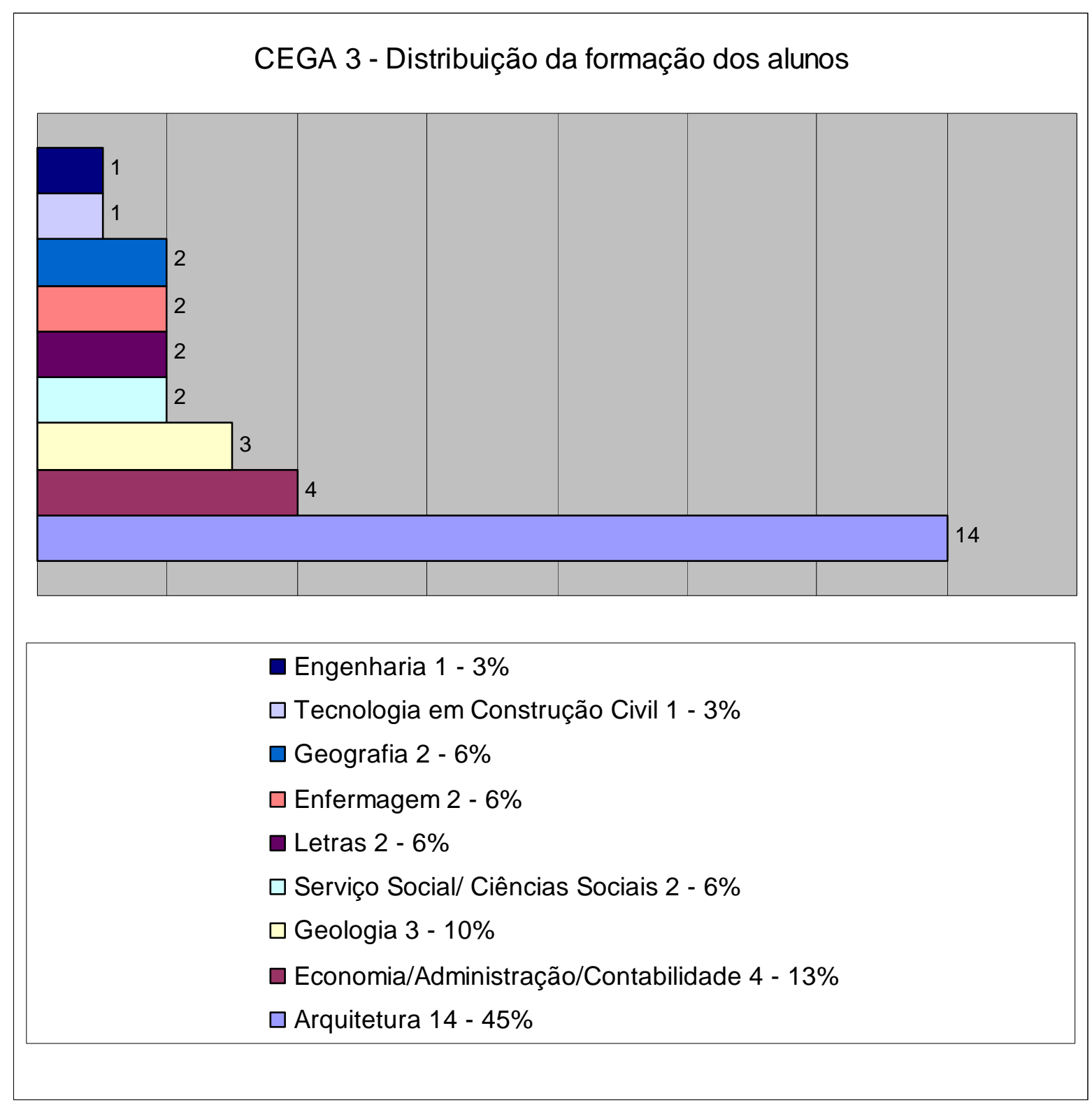


Figura 4.6 - Alunos por gênero (CEGA 3)

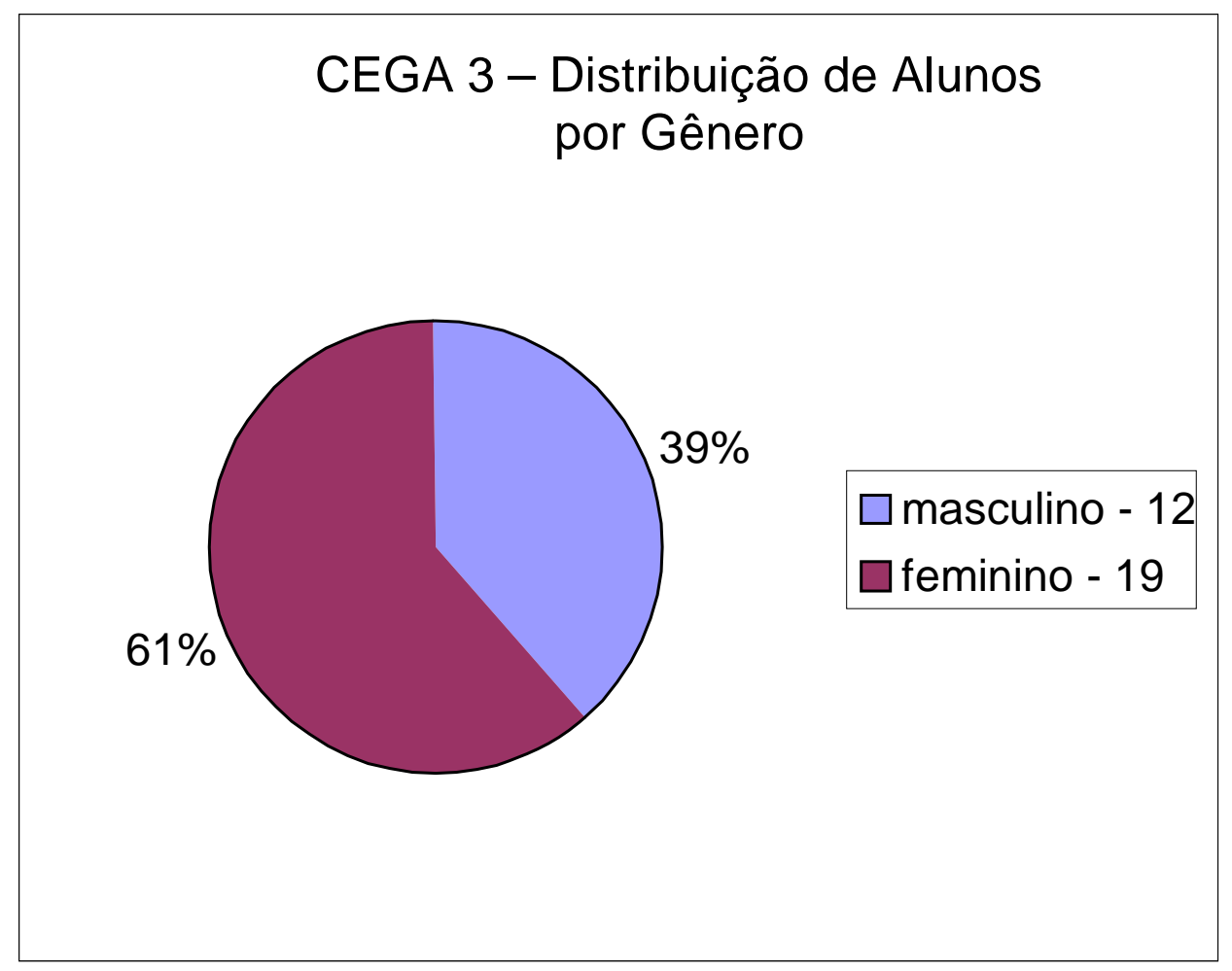

O curso foi composto basicamente por profissionais das áreas de arquitetura $\mathrm{n}=14$ totalizando $45 \%$ dos alunos matriculados (Figura 4.5). Quando iniciaram o curso cerca de 95\% dos alunos atuavam na cidade de São Paulo. Os 31 alunos atuavam no setor público e somente $6 \%$ dos alunos não trabalhavam na área ambiental. De acordo com a figura 4.6, o gênero predominante foi o feminino (61\%). A pequena parcela de profissionais da área de engenharia presentes neste curso, foi devido à ocorrência simultânea de Cursos de Especialização em Engenharia de Saneamento Básico - CEESB, oferecidos pelo NISAM. 
CEGA - 4

Início: fevereiro de 1996

Término: dezembro de 1996

Quantidade de alunos matriculados: 31 alunos

Figura 4.7 - Número de alunos de acordo com a formação profissional (CEGA 4)

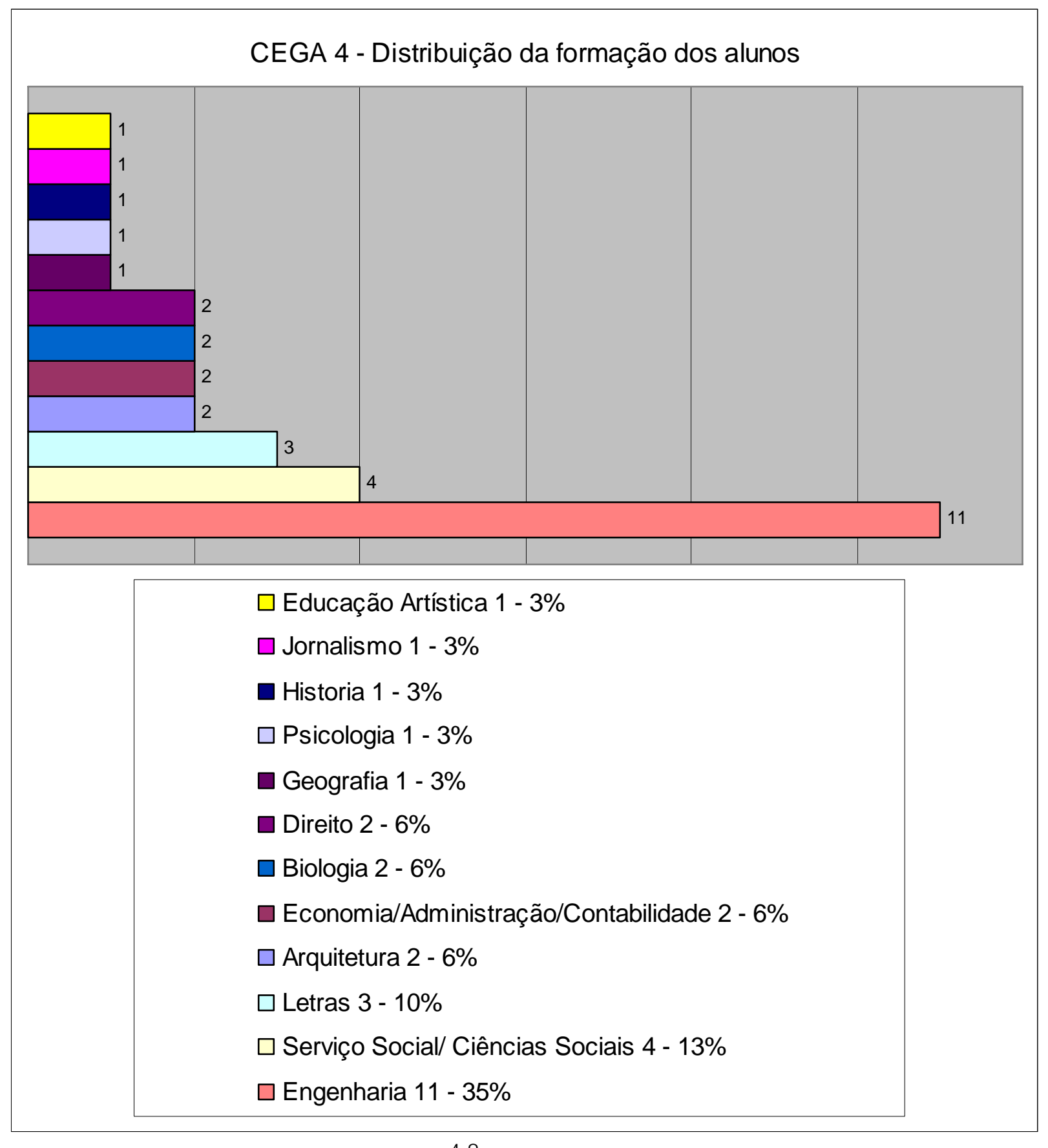


Figura 4.8 - Alunos por gênero (CEGA 4)

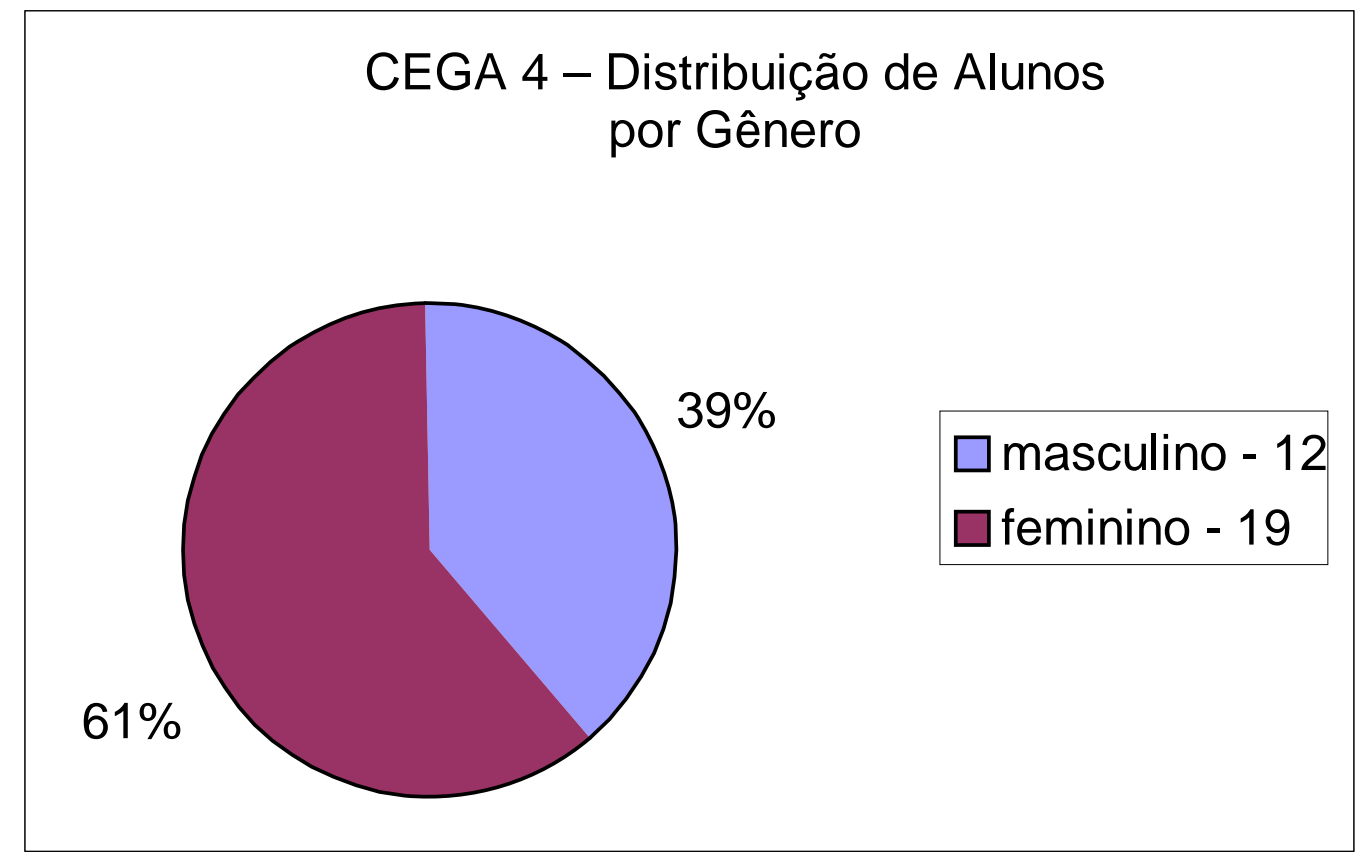

De acordo com a Figura 4.7 o CEGA 4 foi composto por 35\% de profissionais da área de engenharia e o restante ficou distribuído entre profissionais de diversas áreas, com ênfase em serviço social; letras; arquitetura; economia, biologia e direito. Verificou-se que 93\% dos alunos atuavam na cidade de Jundiaí e somente $7 \%$ atuavam na cidade de São Paulo. Vinte e sete alunos eram do setor público e 4 alunos do setor privado. Cerca de 50\% dos alunos trabalhavam na área ambiental. De acordo com a figura 4.8, o gênero predominante foi o feminino (61\%). 
CEGA - 5

Início: agosto de 1997

Término: agosto de 1998

Quantidade de alunos matriculados: 29 alunos

Figura 4.9 - Número de alunos de acordo com a formação, profissional (CEGA 5)

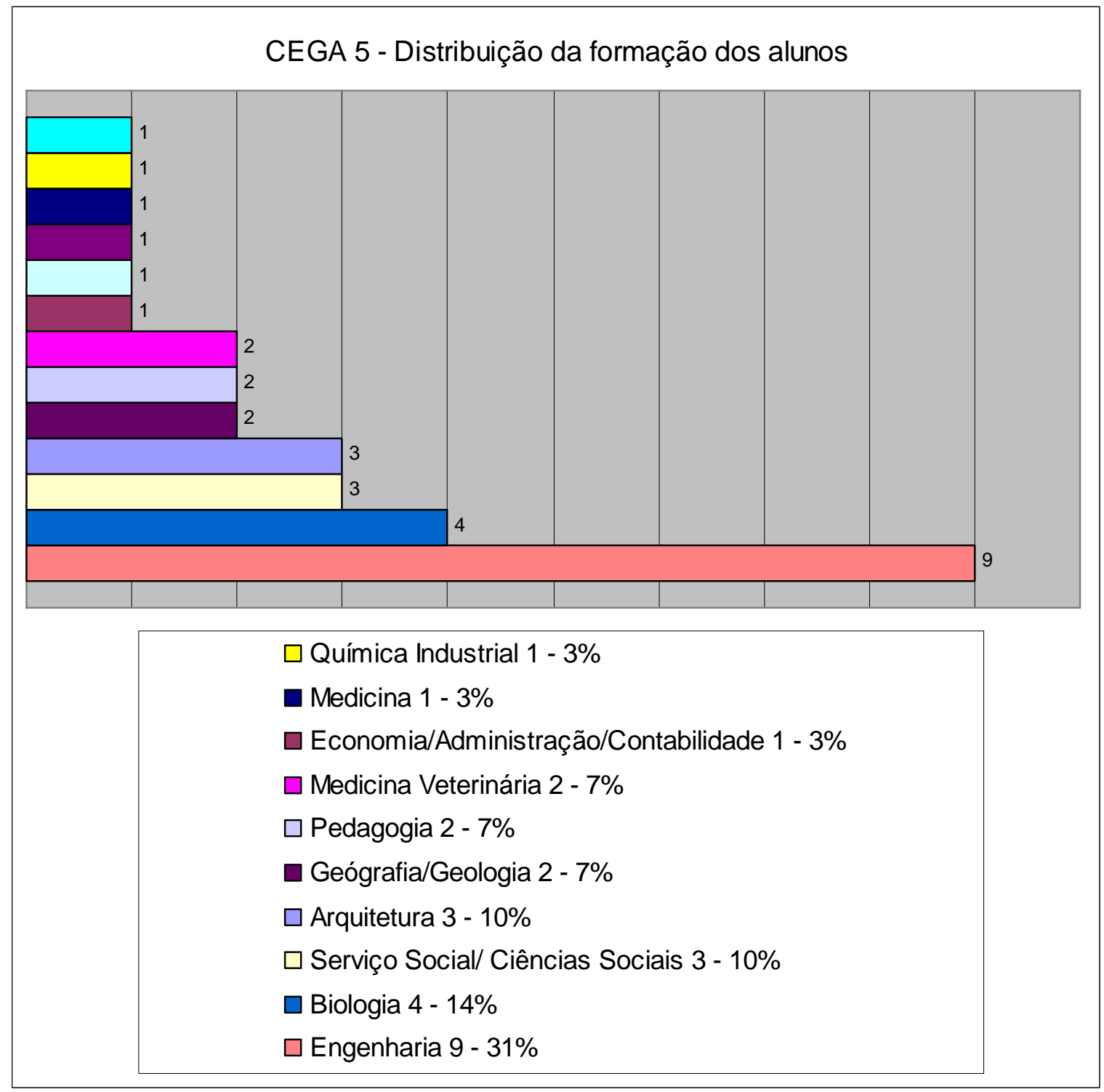


Figura 4.10 - Alunos por gênero (CEGA 5)

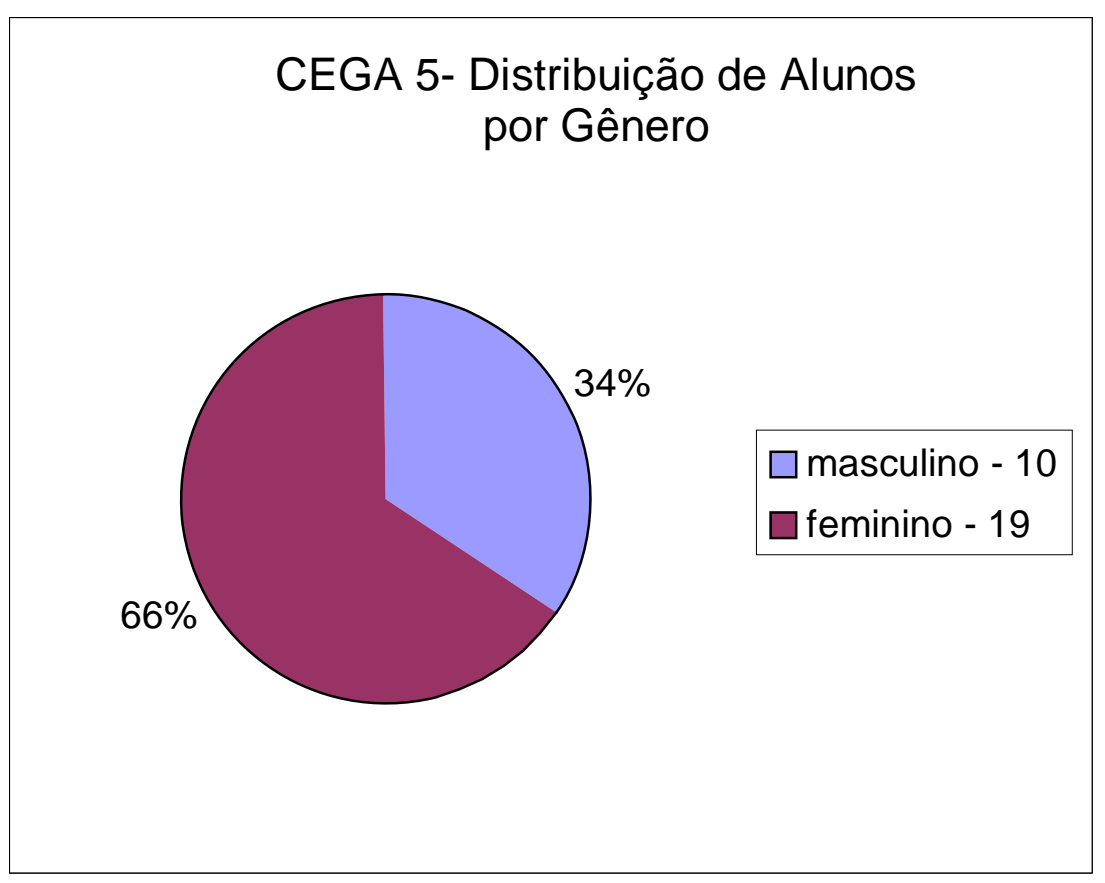

Este curso foi composto por $45 \%$ de profissionais de engenharia e biologia (Figura 4.9), e o restante era da área de serviço social e arquitetura. A totalidade dos alunos (100\%) atuava na cidade de São Paulo, quando iniciaram o curso. Vinte e sete alunos atuavam no setor público e 4 alunos no setor privado. Estavam atuando na área ambiental cerca de 90\% dos alunos. De acordo com a figura 4.10, o gênero predominante foi o feminino (66\%). 
CEGA - 6

Início: agosto de 1997

Término: agosto de 1998

Quantidade de alunos matriculados: 26 alunos

Figura 4.11 - Número de alunos de acordo com a formação, profissional (CEGA 6)

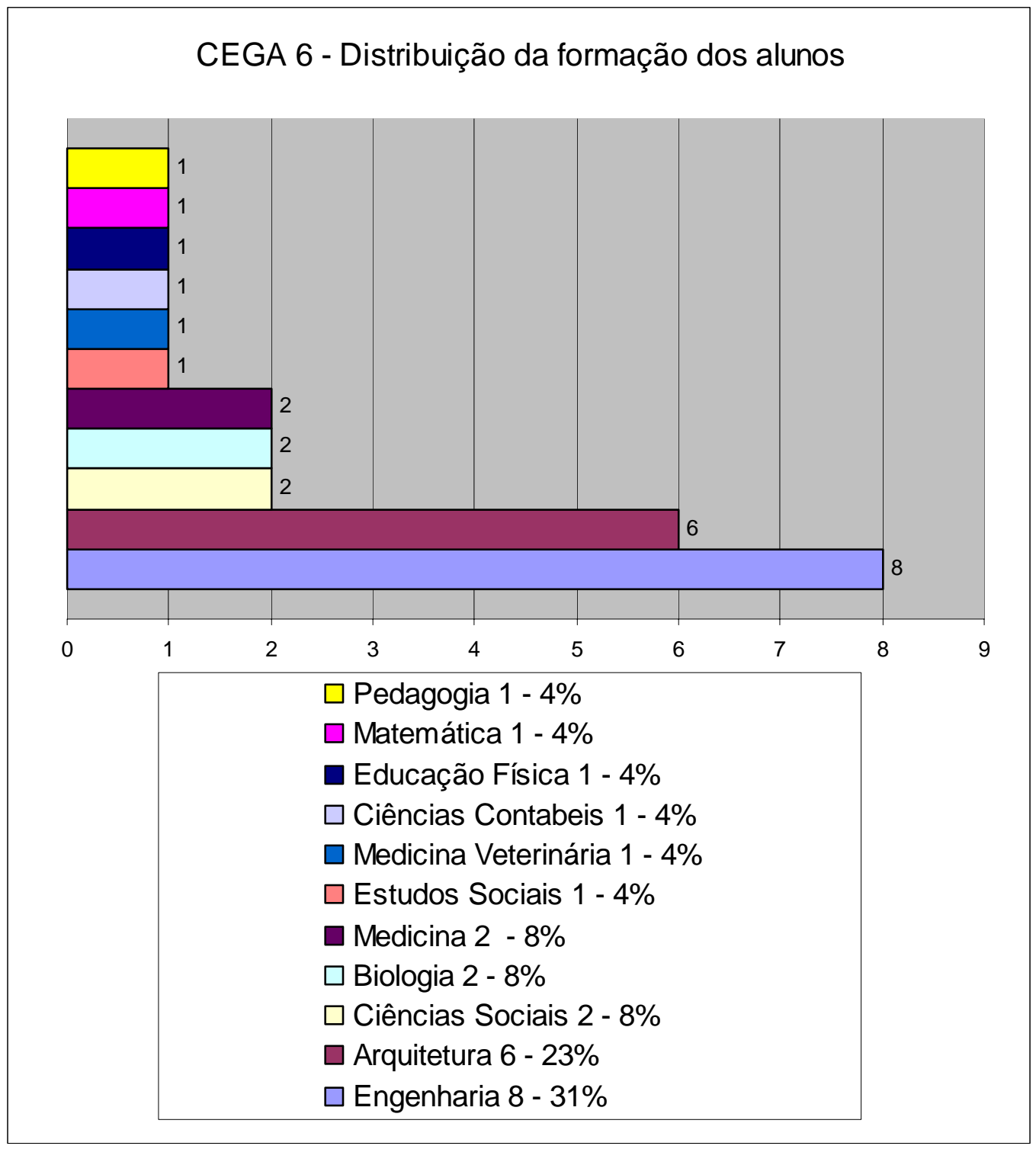


Figura 4.12 - Alunos por gênero (CEGA 6)

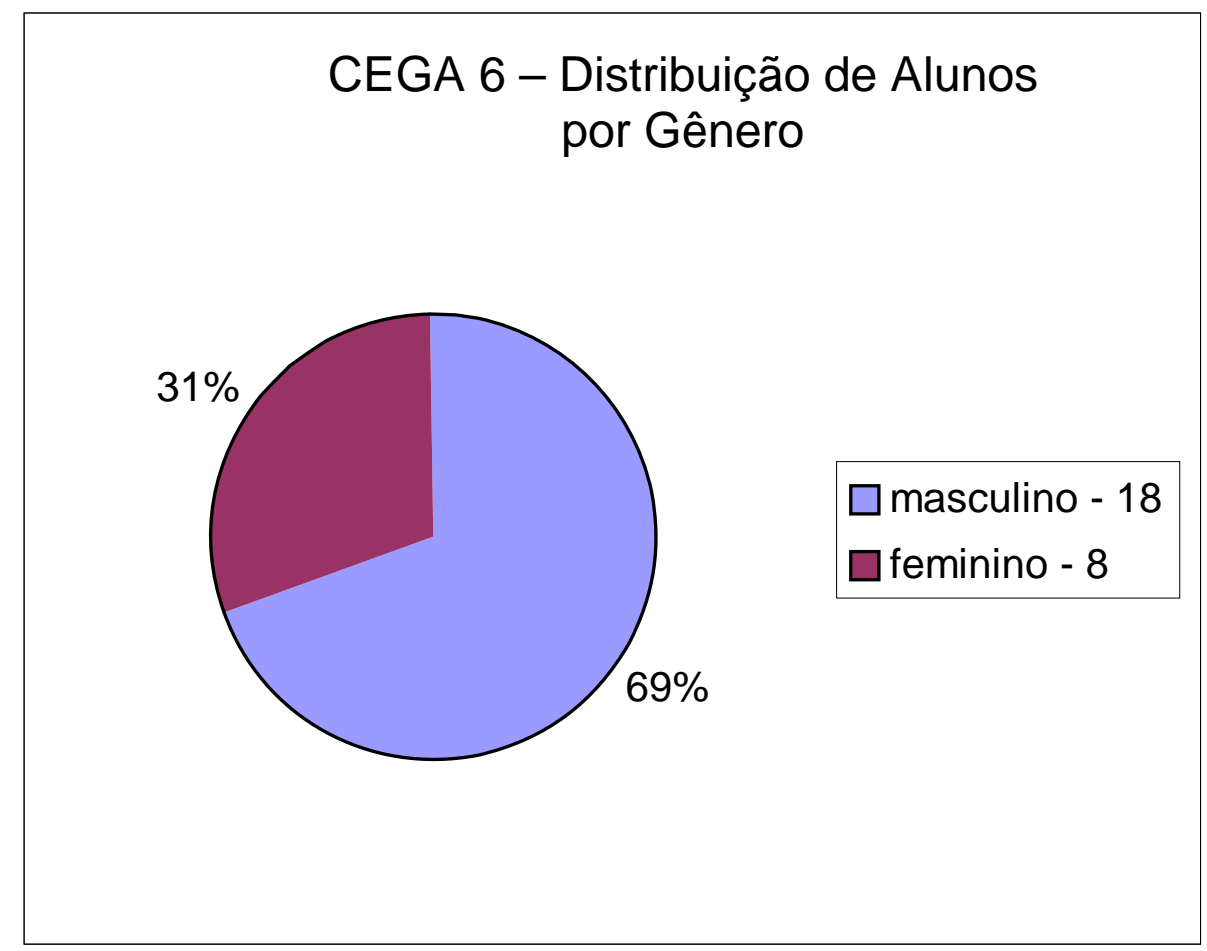

A área de arquitetura e engenharia representou 54\% do curso (Figura 4.11) e o restante as áreas de ciências sociais, biologia e medicina. Cerca de 50\% dos alunos atuavam na cidade de São Paulo, e o restante entre Guarulhos, Campinas, Taboão da Serra, Osasco e Jacareí. Atuavam no setor público cerca de $54 \%$ dos alunos e $26 \%$ no setor privado, sendo que $54 \%$ dos alunos trabalhavam na área ambiental. De acordo com a figura 4.12, 0 gênero predominante foi o masculino (69\%). 
CEGA - 7

Início: março de 1998

Término: dezembro de 1998

Quantidade de alunos matriculados: 34 alunos

Figura 4.13 - Número de alunos de acordo com a formação profissional - CEGA 7

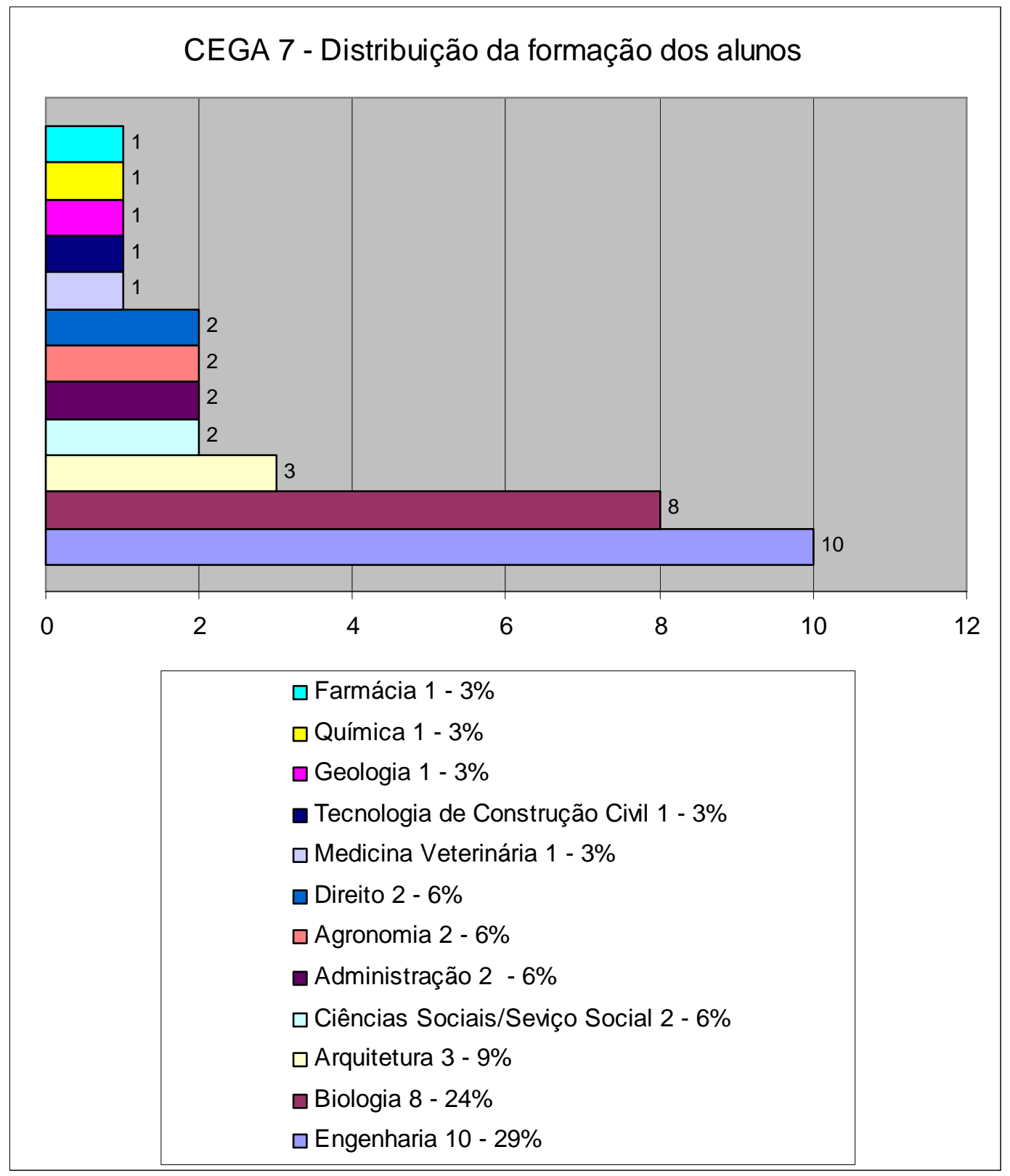


Figura 4.14 - Alunos por gênero (CEGA 7)

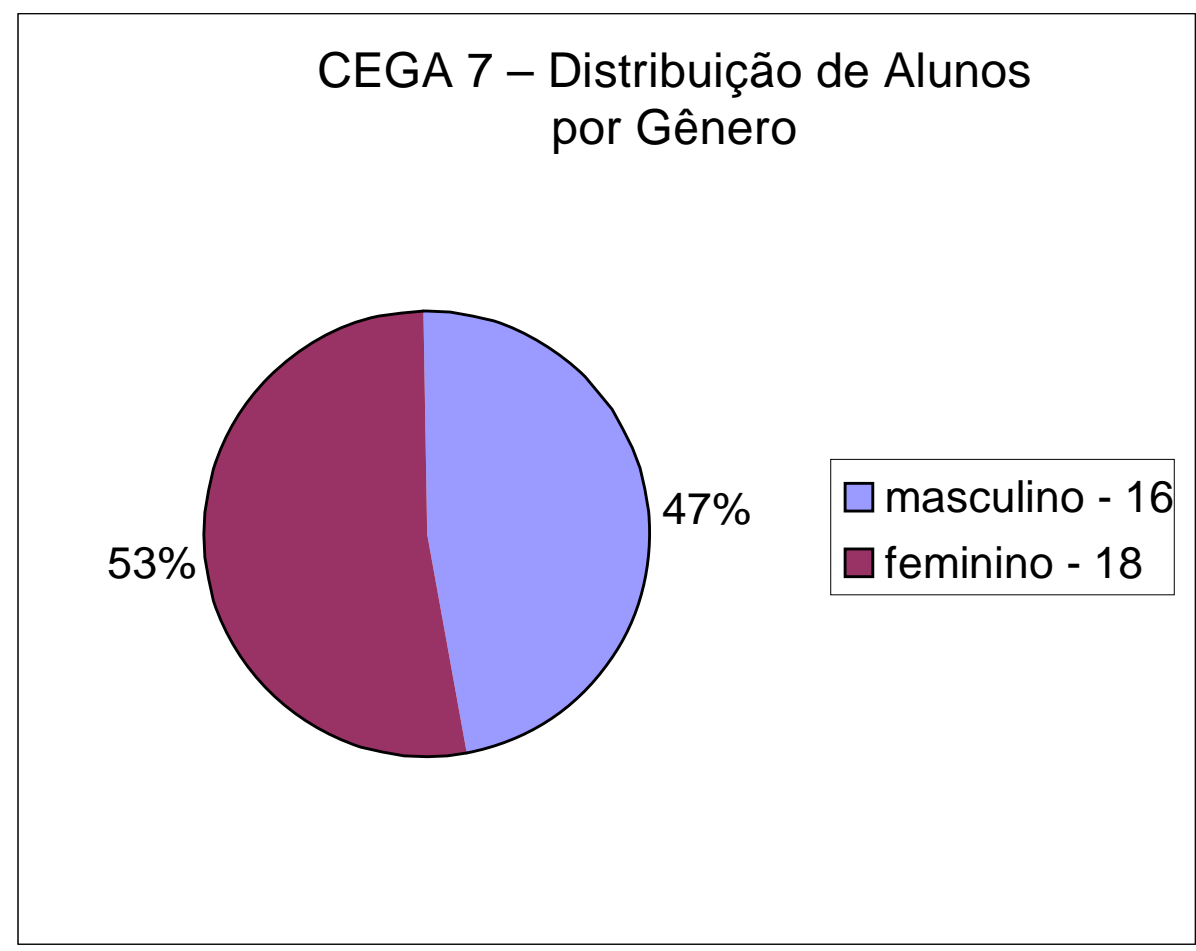

Os profissionais das áreas de engenharia e biologia (53\%) foram maioria no CEGA 7 e o restante eram profissionais das áreas de arquitetura e outras (Figura 4.13). Cerca de $82 \%$ dos alunos atuavam na cidade de São Paulo, e os demais entre Guarulhos, Diadema, Mogi das Cruzes, Embu e Salesópolis. Trabalhavam nos setores público (23,5\%), privado (50\%) e 2,9\% em ONG. Cerca de 44\% dos alunos trabalhavam na área ambiental, $32 \%$ trabalhavam em outras áreas e $24 \%$ não responderam. De acordo com a figura 4.14, o gênero predominante foi o feminino (53\%). 


\section{CEGA - 8}

Início: julho de 1998

Término: agosto de 1999

Quantidade de alunos matriculados: 38 alunos

Figura 4.15 - Número de alunos de acordo com a formação profissional - CEGA 8

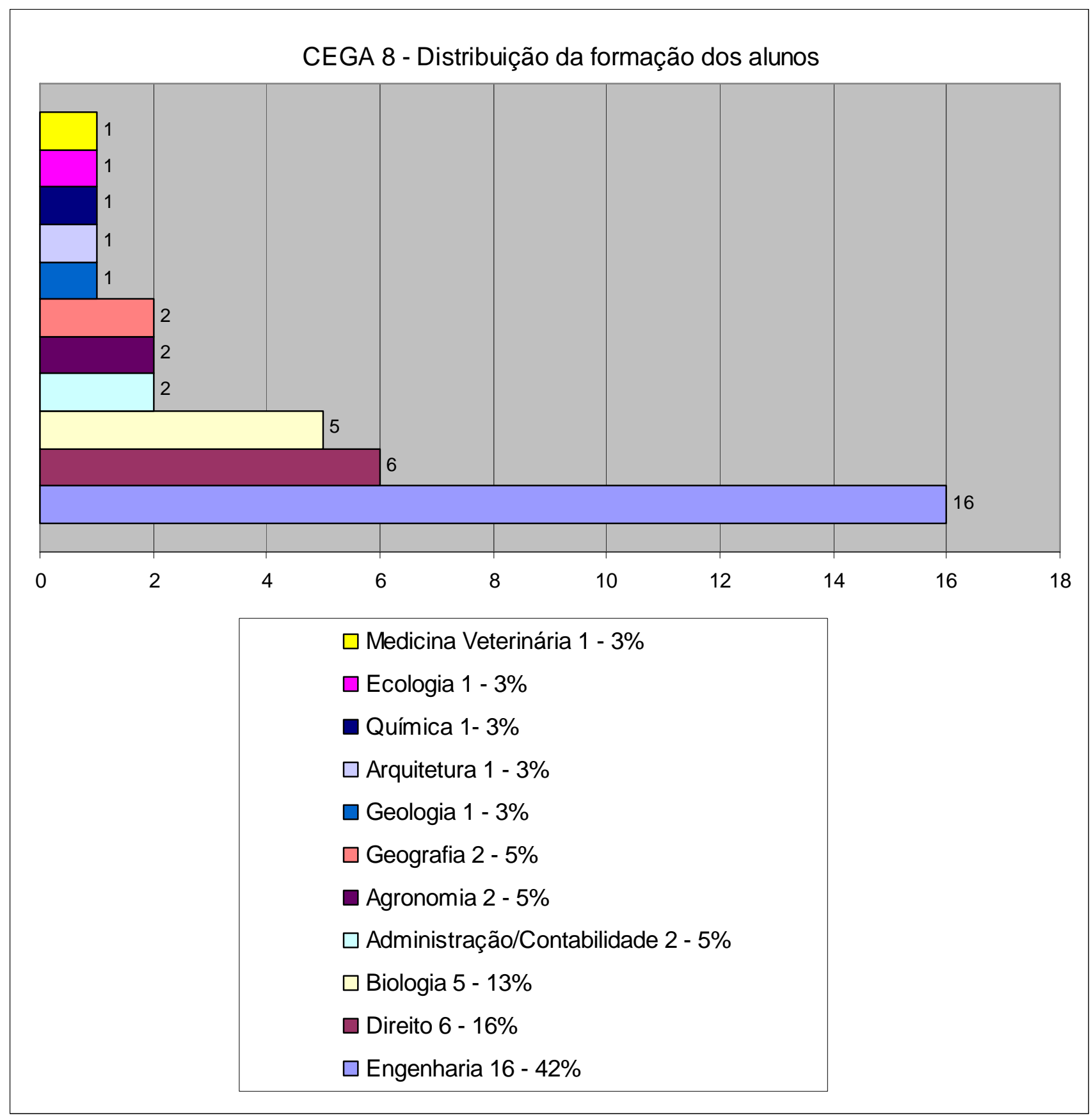


Figura 4.16 - Alunos por gênero - (CEGA 8)

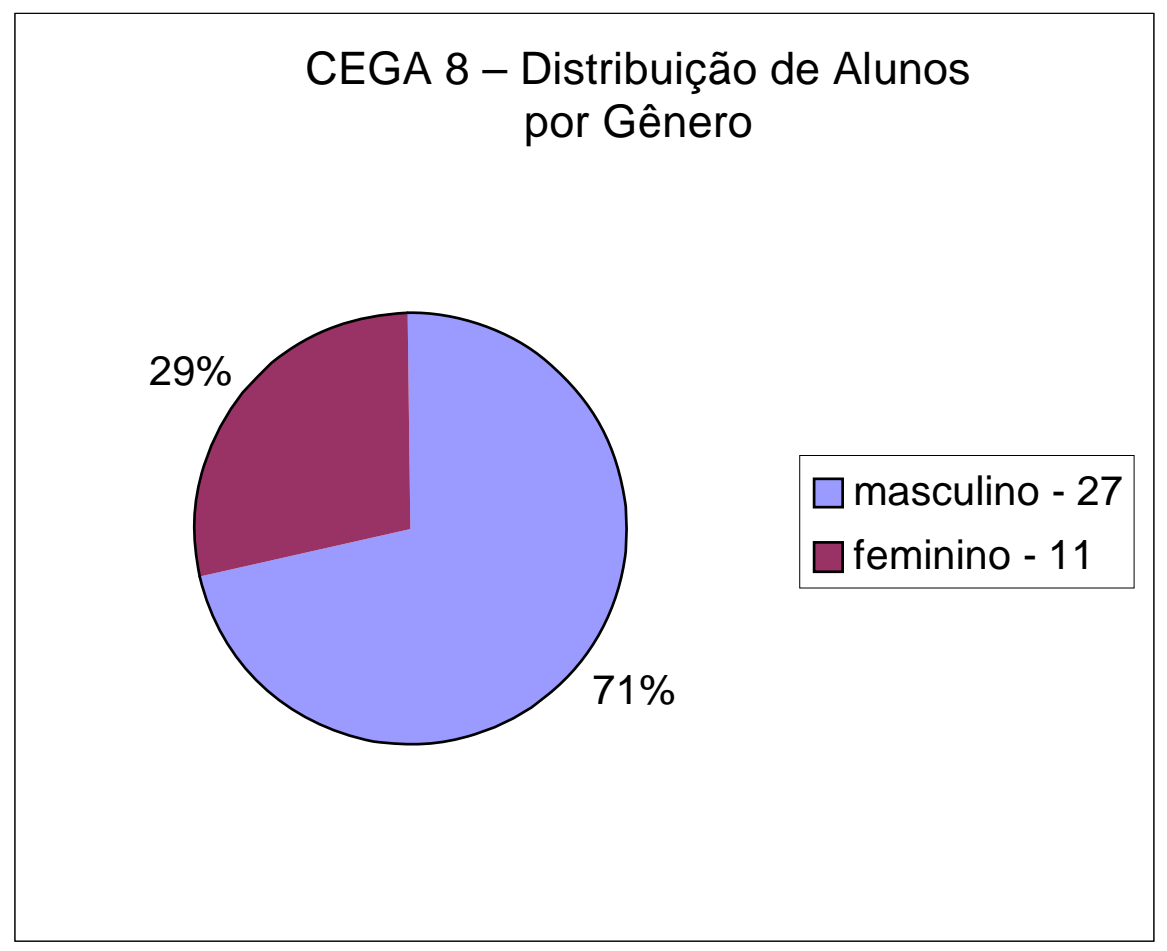

A maioria dos alunos (71\%) conforme Figura 4.16 eram das áreas de engenharia, direito e biologia. A participação constante de alunos da área do direito levou a equipe de coordenação dos cursos de especialização do NISAM, a avaliar a possibilidade da criação de curso específico na área do Direito Ambiental. Cerca de $84 \%$ dos alunos atuavam na cidade de São Paulo, e o restante em Guarulhos, Ribeirão Pires, Lins, Embu, Sorocaba ou Cubatão. Eram do setor público 40,5\% dos alunos, 56,6\% do setor privado e 2,7\% atuavam em ONGs. Cerca de 51,3\% dos alunos trabalhavam na área ambiental, 48,7\% em outras áreas. Com relação ao ano de conclusão, 50\% dos alunos possuíam até 8 anos de formados e os 50\% restantes, mais de 8 anos. De acordo com a figura 4.16, o gênero predominante foi o masculino (71\%). 
CEGA - 9

Início: agosto de 1999

Término: agosto de 2000

Quantidade de alunos matriculados: 34 alunos

Figura 4.17 - Número de alunos de acordo com a formação profissional - CEGA 9

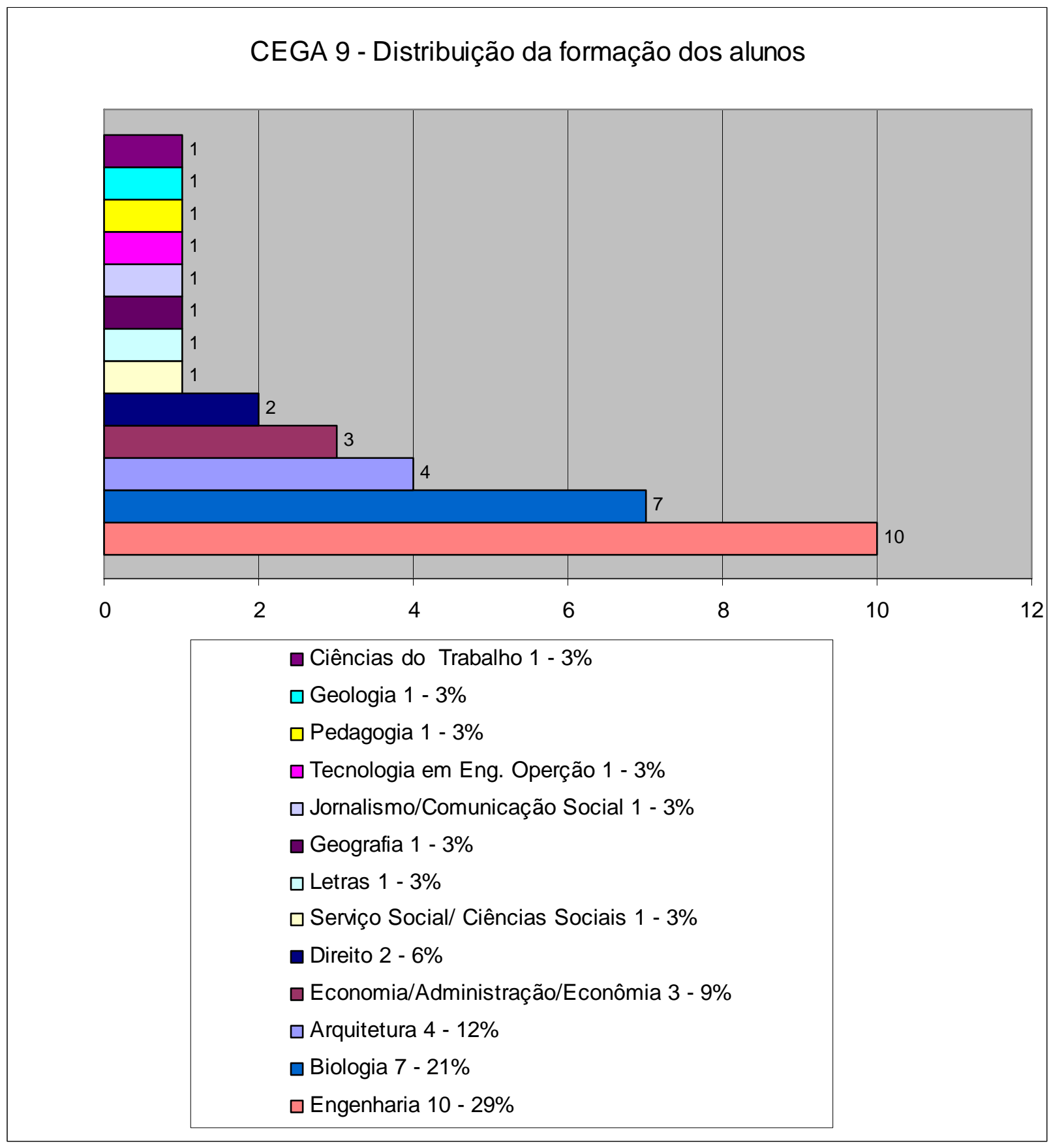


Figura 4.18 - Alunos por gênero (CEGA 9)

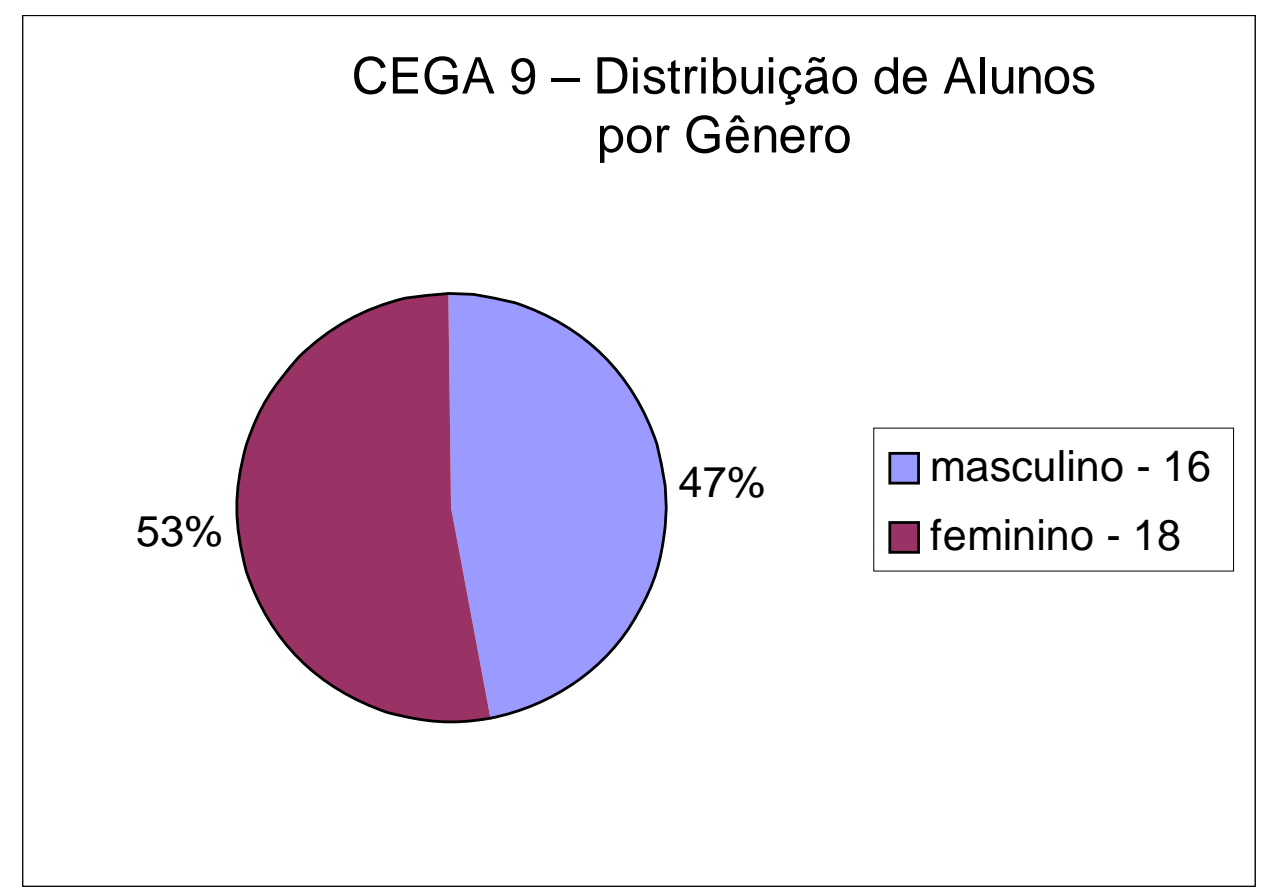

Quase metade dos alunos (49\%) de acordo com a figura 4.17, era composta por profissionais da área de engenharia e biologia. Cerca de $83 \%$ dos alunos atuavam na cidade de São Paulo, e os demais eram de Santo André, São Bernardo do Campo, São Lourenço da Serra, Osasco, Colômbia. Com relação aos setores $43 \%$ dos alunos atuavam no setor público e $57 \%$ no privado. Cerca de $82 \%$ dos alunos trabalhavam na área ambiental e $18 \%$ em outras áreas. Com relação ao ano de conclusão, $72 \%$ dos alunos possuíam até 13 anos de formados. De acordo com a figura 4.18, o gênero predominante foi o feminino (53\%). 
CEGA - 10

Início: fevereiro de 2000

Término: dezembro de 2000

Quantidade de alunos matriculados: 34 alunos

Figura 4.19 - Número de alunos de acordo com a formação profissional - CEGA 10

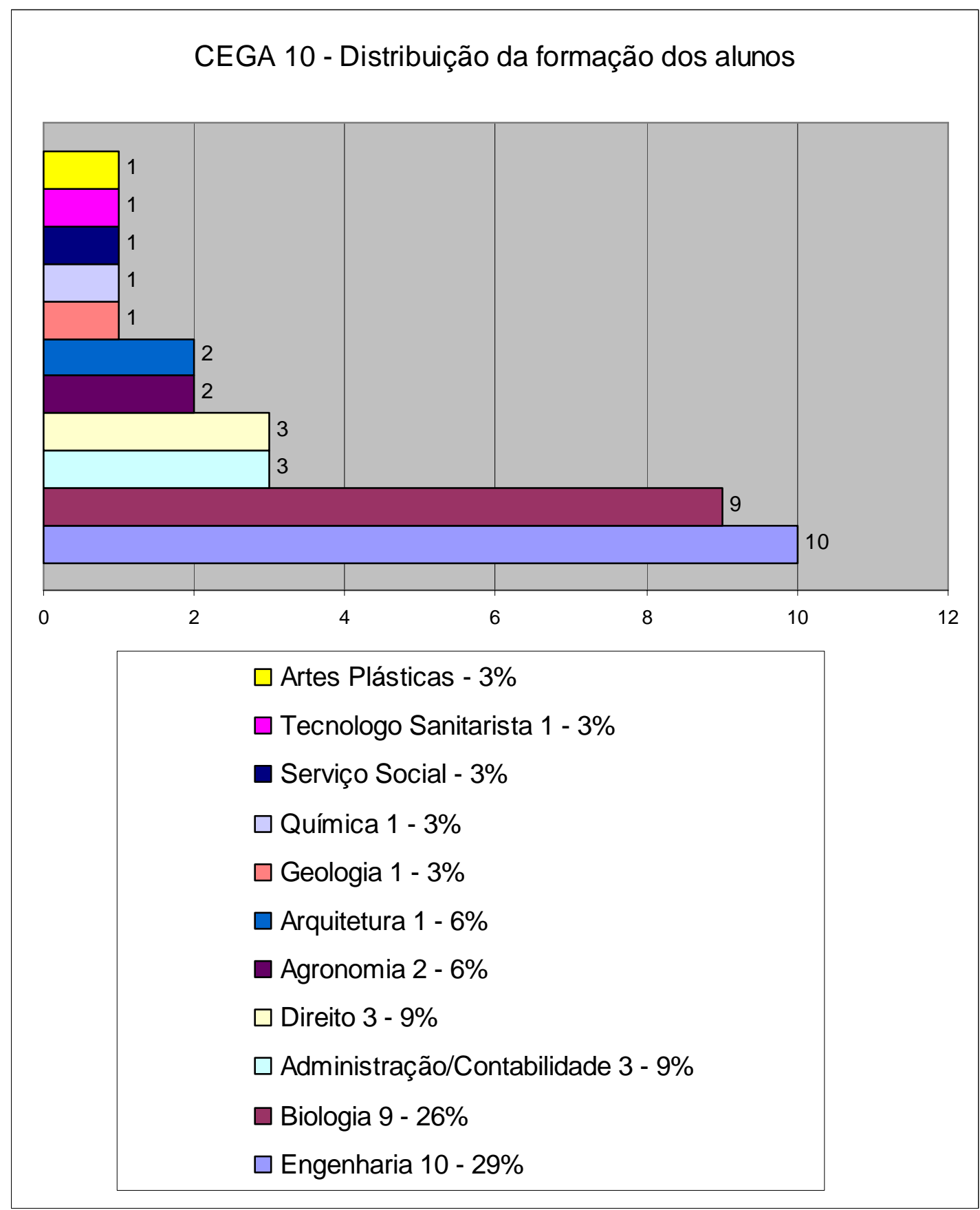


Figura 4.20 - Alunos por gênero - (CEGA 10)

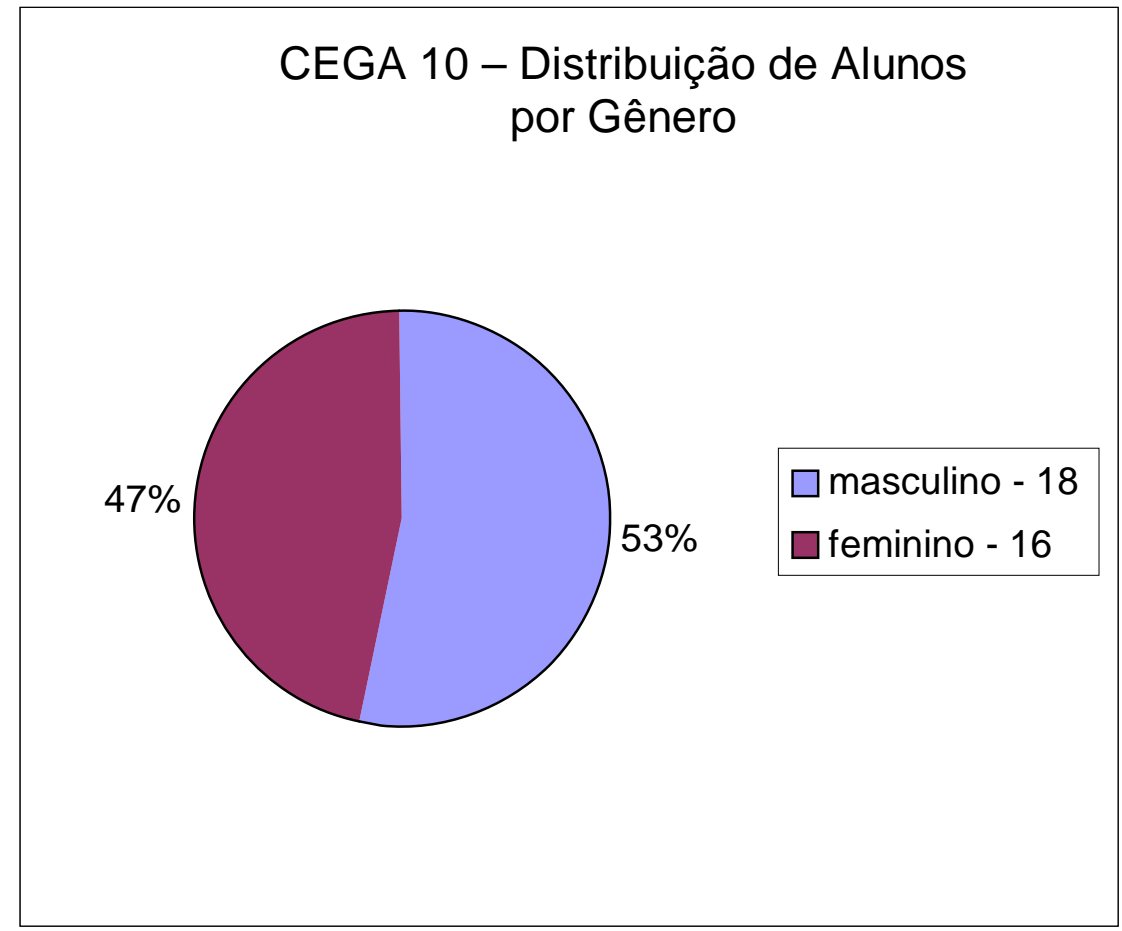

Com relação a composição dos alunos, uma parcela significativa dos profissionais ( $55 \%$ ) era composta por profissionais da área de engenharia e biologia. (Figura 4.19). Vale ressaltar a presença constante de biólogos e geógrafos nos cursos CEGA, devido principalmente ao desejo de ampliação de possibilidades profissionais. Cerca de $70 \%$ dos alunos atuavam na cidade de São Paulo, e o restante entre Santos, Santo André, Osasco, Campinas, Manaus, Sumaré, São Caetano do Sul e Salto. Com relação aos setores constatou-se que $49 \%$ dos alunos eram do público, $43 \%$ do privado e $8 \%$ de ONGs. Cerca de 52\% dos alunos trabalhavam na área ambiental e 48\% em outras áreas. Com relação ao ano de conclusão, 80\% dos alunos possuíam até 09 anos de formados. De acordo com a figura 4.20, o gênero predominante foi o masculino (53\%). 
CEGA - 11

Início: fevereiro de 2000

Término: dezembro de 2000

Quantidade de alunos matriculados: 38 alunos

Figura 4.21 - Número de alunos de acordo com a formação profissional - CEGA 11

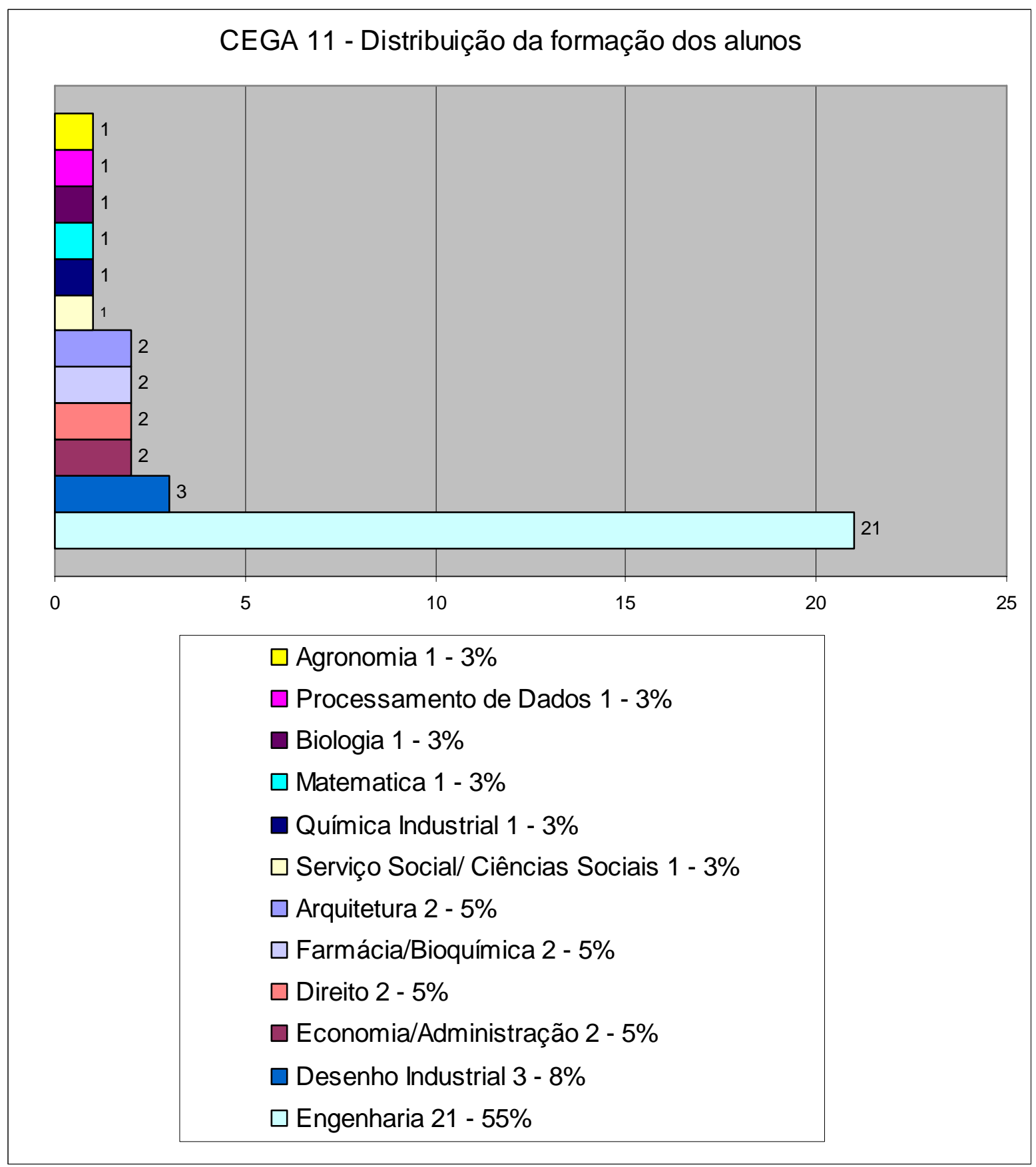


Figura 4.22 - Alunos por gênero (CEGA 11)

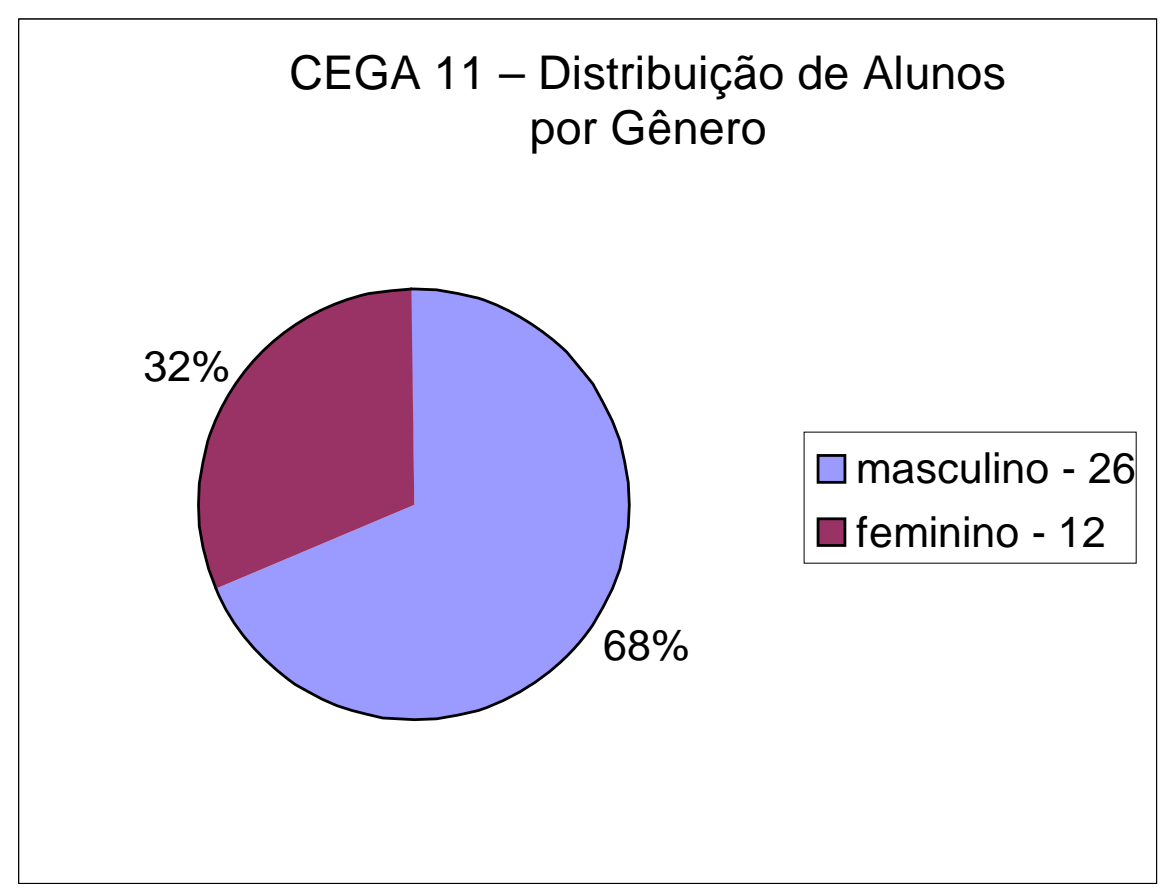

Mais da metade dos alunos (55\%) da turma CEGA 11 foi composta por profissionais da área de engenharia (Figura 4.21) e o restante ficou distribuído entre os profissionais das outras áreas. Esta participação majoritária dos engenheiros foi decorrente do fato do curso CEGA 11 ter sido realizado na sede da Associação dos Engenheiros e Arquitetos de Bauru conveniada com a ABES - Associação Brasileira de Engenharia Sanitária e Ambiental com a interveniência do NISAM. Cerca de 53\% dos alunos atuavam na cidade de São Paulo, e o restante entre Jaú, Campinas, Lençóis Paulistas, Ribeirão Preto, Botucatu, Lins, Rio Claro, Cafelândia, Bariri, Ibitinga, Votorantin, Ibitinga e Agudos. Cerca de 53\% dos alunos atuavam no setor público e $47 \%$ no setor privado, mas $50 \%$ na área ambiental. Com relação ao ano de conclusão, 55\% dos alunos possuíam até 14 anos de formados. De acordo com a figura 4.22, o gênero predominante foi 0 masculino (68\%). 
CEGA - 12

Início: agosto de 2000

Término: julho de 2001

Quantidade de alunos matriculados: 32 alunos

Figura 4.23 - Número de alunos de acordo com a formação profissional - CEGA 12

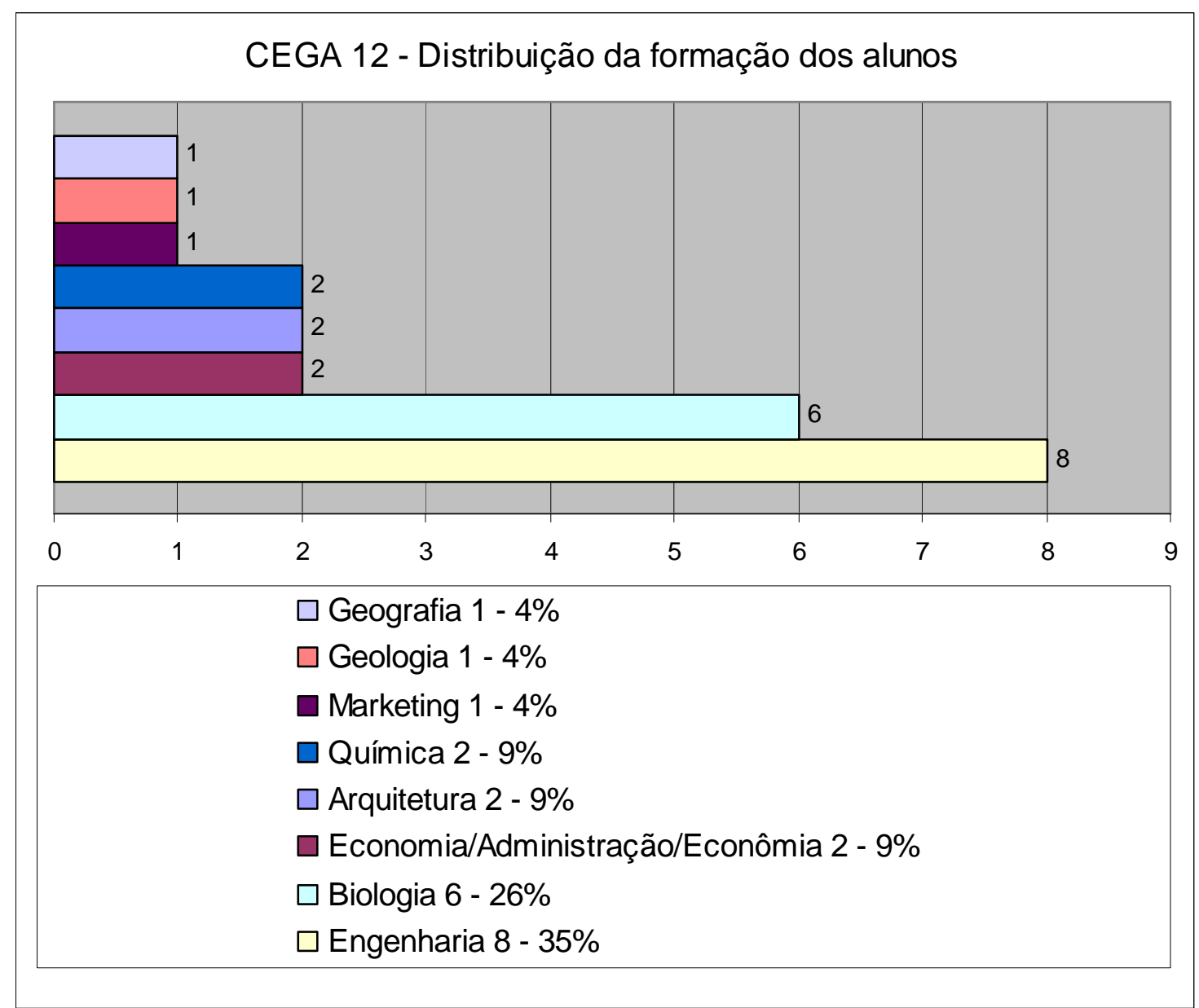


Figura 4.24 - Alunos por gênero (CEGA 12)

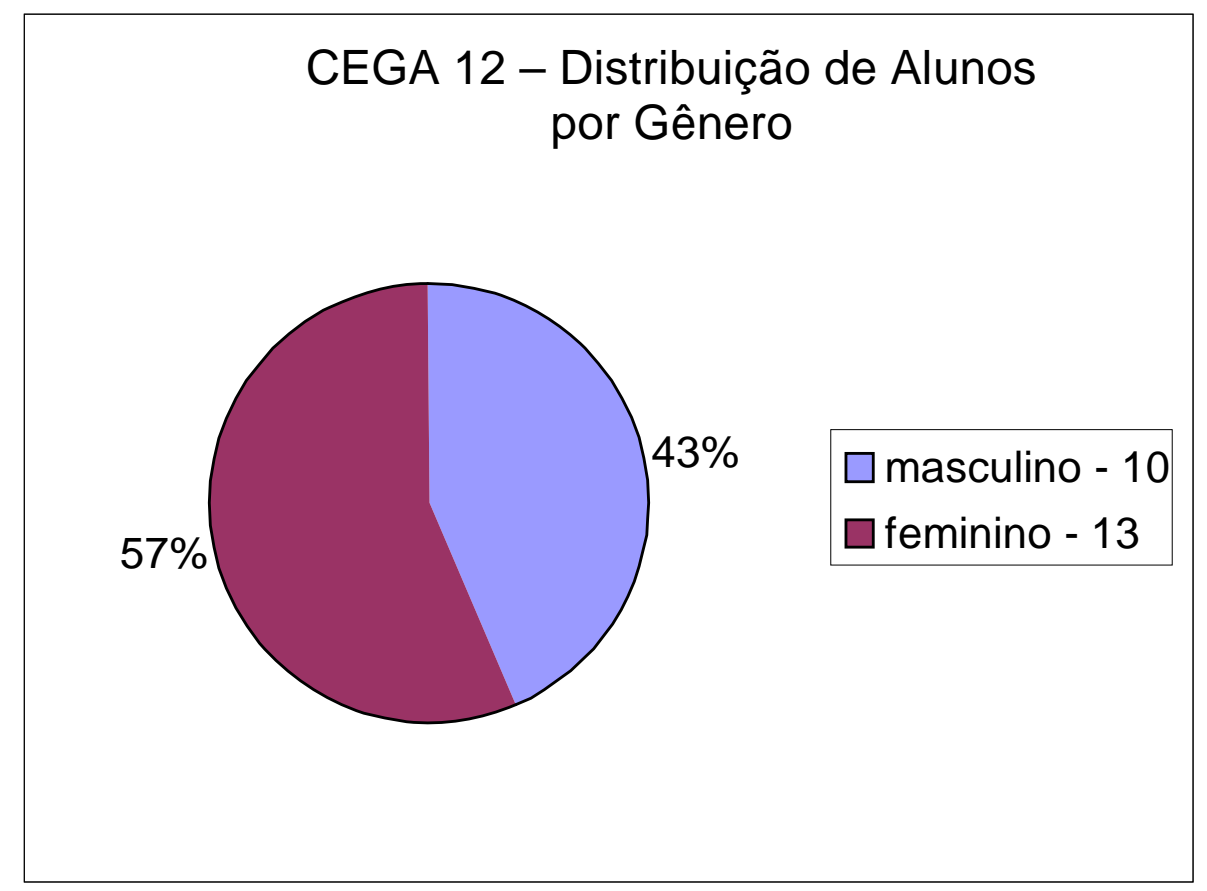

As áreas de engenharia e biologia contribuíram com 61\% do total dos alunos do CEGA 12 (Figura 4.23). Cerca de 69\% dos alunos atuavam na cidade de São Paulo, e os demais distribuídos entre Campinas, Sorocaba, Taboão da Serra, São Caetano do Sul, São Bernardo do Campo e Guarulhos. Com relação ao setor de atuação verificou-se que 36\% dos alunos atuavam no setor público e $64 \%$ no privado, sendo que 32\% dos alunos trabalhavam na área ambiental. Com relação ao ano de conclusão, 80\% dos alunos possuíam até oito anos de formação. De acordo com a figura 4.24, o gênero predominante foi o feminino (57\%). 


\section{CEGA - 13}

Início: fevereiro de 2001

Término: dezembro de 2001

Quantidade de alunos matriculados: 28 alunos

Figura 4.25 - Número de alunos de acordo com a formação profissional CEGA 13

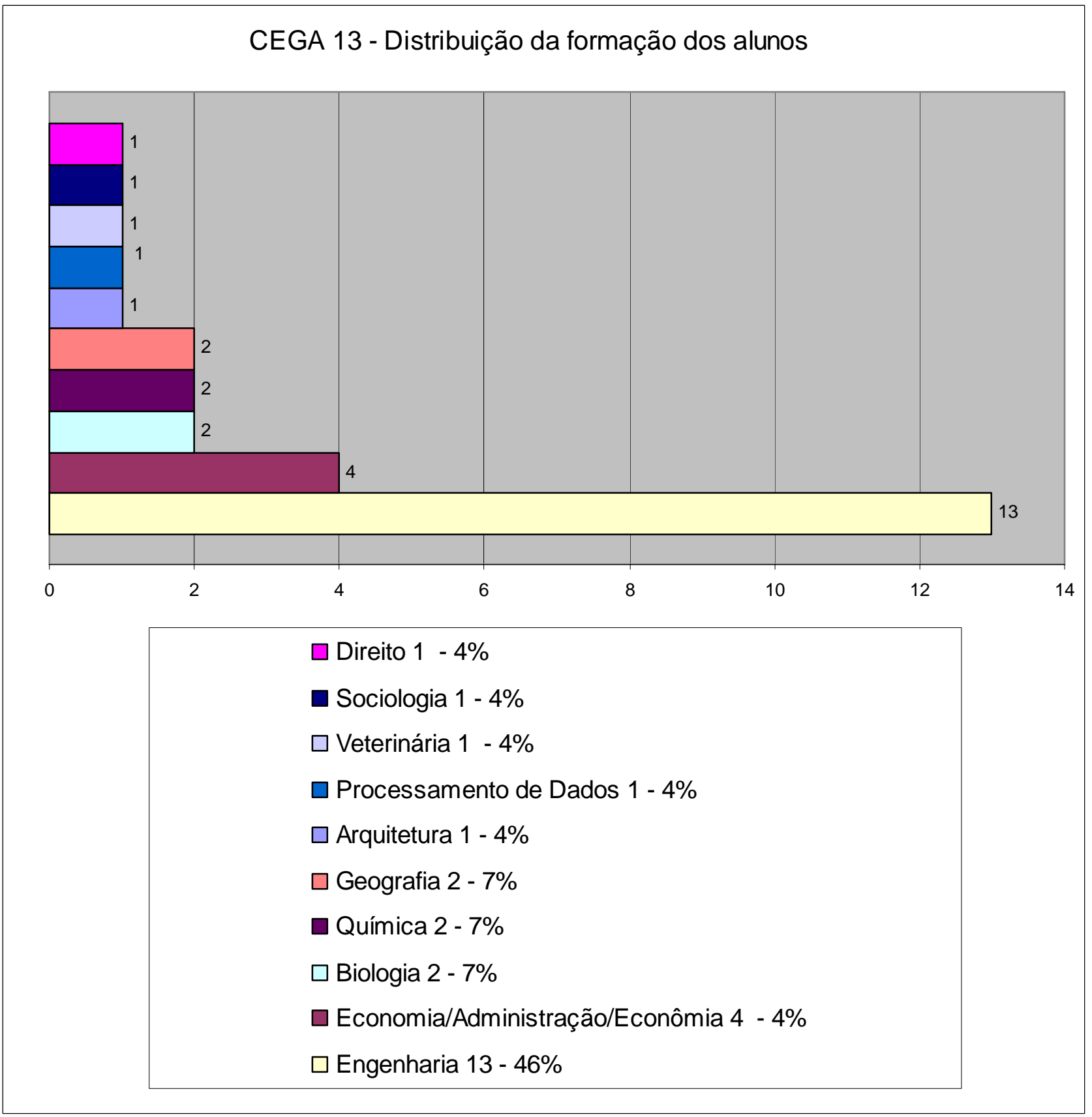


Figura 4.26 - Alunos por gênero (CEGA 13)

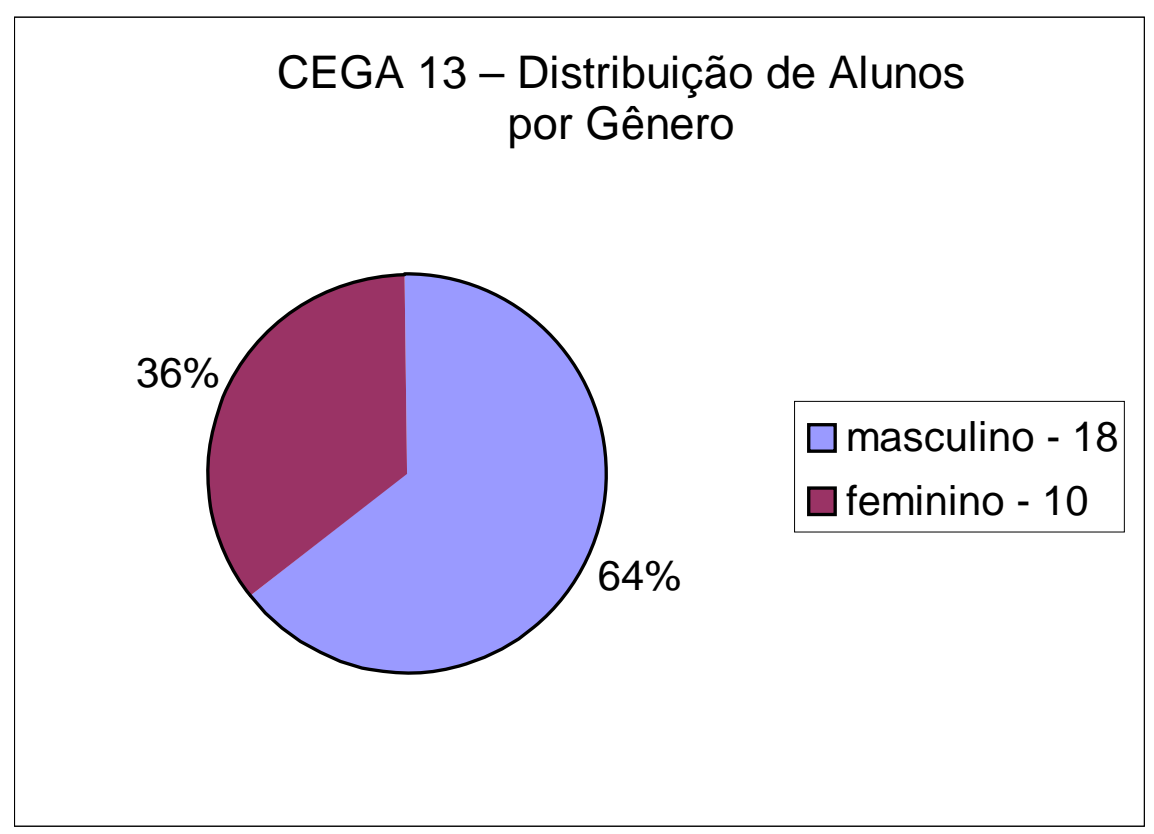

A área de engenharia contribuiu com 46\% dos alunos do CEGA 13 (Figura 4.25) e os demais distribuídos entre profissionais de diversas outras áreas. A atuação dos alunos concentrou-se em São Paulo (66\%) e os demais entre Guarulhos, Santo André, Santa Bárbara d’Oeste, Vargem Grande Paulista e Campo Limpo. Cerca de $56 \%$ dos alunos atuavam no setor público, 35\% atuavam no setor privado, 9\% em ONGs e destacando-se que 89\% dos alunos trabalhavam na área ambiental. Com relação ao ano de conclusão, $80 \%$ dos alunos possuíam até 15 anos de formados. O gênero predominante foi o masculino (64\%) de acordo com a figura 4.26 . 


\subsubsection{Produção discente por área do conhecimento}

A temática abordada e escolhida para a redação de trabalhos finais de conclusão de curso, denotaram dois fatores: inicialmente as aspirações conjuntas nos momentos iniciais do curso quando são selecionados os grandes temas e as áreas de pesquisa e, posteriormente, o recorte temáticometodológico definido, ao finalizar a pesquisa na conclusão do curso. Os alunos produziram 93 trabalhos finais, redigidos em grupos de no mínimo 3 e no máximo 4 alunos. A relação dos títulos das monografias e conseqüentemente as opções temáticas adotadas por todos os alunos dos treze cursos avaliados encontram-se no ANEXO 7. Para efeito de análise, os assuntos abordados nestes 93 trabalhos, foram agrupados em nove temas cujos conteúdos e relevâncias são descritos a seguir. (Ver também Tabela 4.1.)

Tabela 4.1 - Trabalhos Finais de Conclusão de Curso agrupadas por área do conhecimento

\begin{tabular}{||c|l|c|c||}
\hline \hline Áreas & \multicolumn{1}{|c|}{ Temas } & Freq. absoluta & \% por área \\
\hline 1 & Resíduos & 21 & 22,6 \\
\hline 2 & Gestão Ambiental e Urbana & 20 & 21,5 \\
\hline 3 & $\begin{array}{l}\text { SNUC, Mananciais, } \\
\text { Preservação, Proteção }\end{array}$ & 14 & 15,1 \\
\hline 4 & Recursos Hídricos & 12 & 12,9 \\
\hline 5 & Poluição e Transporte & 12 & 12,9 \\
\hline 6 & Educação Ambiental & 5 & 5,4 \\
\hline 7 & Participação Comunitária & 4 & 4,3 \\
\hline 8 & Energia & 3 & 3,2 \\
\hline 9 & Certificação/Normatização & 2 & 2,2 \\
\hline TOTAL & & 93 & 100,0 \\
\hline \hline
\end{tabular}


- Resíduos

Os trabalhos $(\mathrm{n}=21)$ sobre resíduos, $22,6 \%$ do total desenvolvido, conforme Tabela 4.1, mostraram a problemática dos resíduos que vem se revelando cada vez mais importante, pois apesar do aumento da urbanização e das inovações tecnológicas, não é tão simples realizar a absorção dos resíduos por um processo natural de reciclagem. Enquanto cerca de $65 \%$ do total gerado é constituído por organismos orgânicos, outros resíduos sólidos precisam sofrer processos específicos de reciclagem para serem reabsorvidos pela sociedade. Muitas vezes também não é mais possível contar unicamente com o aterro sanitário, pois as altas densidades de ocupação urbana estão produzindo volumes cada vez maiores de resíduos sólidos.

Além disso, uma disposição inadequada destes, sem a devida atenção quanto à qualidade do lixo e grau de toxidade, sem contar com um projeto para tratamento e coleta do chorume, pode levar à poluição do solo e águas, tanto subterrâneas, como de córregos e represas. O poder público precisa controlar tanto a poluição, como a disposição, tratamento e reciclagem dos resíduos sólidos. Como se pode observar, cada vez mais é importante conscientizar a população sobre os problemas para a saúde humana e ambiental, advindos da geração de resíduos e da ausência de tratamento e de coleta. As atividades de Educação e de Gestão Ambiental devem ganhar, portanto, prioridade de enfoque pelo poder público, tanto em suas ações diretas, como indiretas, por meio de políticas públicas que cada vez mais se tornam necessárias.

- Gestão Ambiental e Urbana

Os trabalhos $(n=20)$ dos alunos sobre esta área do conhecimento, $21,5 \%$ do total desenvolvido, foram desenvolvidos justificando-se a problemática da 
Gestão Ambiental Urbana que vem adquirindo importância, pois a concentração da população nas cidades vem aumentando cada vez mais com repercussões sócio-econômicas no ambiente construído, e em muitos casos levando a situações de extrema degradação do ambiente natural também (Tabela 4.1). A interdependência entre as condições físicogeográficas e ecológicas do sítio, associada à interdependência crescente das ações humanas no território, por vezes tem produzido um desenvolvimento não sustentável. Algumas ações geram poluição e disseminam vetores que afetam a saúde humana e ambiental, ou provocam emissões nocivas ao meio ambiente. Assim, o uso e ocupação do solo merecem atenção prioritária, na Gestão Ambiental Urbana. Nesta, cada vez mais a participação da comunidade ganha importância, seja em sociedades de bairros ou de classes, seja conseguindo o compromisso de empresários, em negócios de pequeno, médio e grande porte. Pode-se vislumbrar as perspectivas de participação, de diversas formas: em grupos técnicos; no exercício de cidadania; e em parcerias dos setores público e privado.

- Sistema Nacional de Unidas de Conservação (SNUC), Mananciais, Preservação, Proteção

Estes temas $(n=14)$ mostram que atualmente há consenso, sobre a importância das áreas verdes para a melhoria das condições ambientais, tanto em termos de ambiente natural, como construído e representaram, $15,1 \%$ do total desenvolvido. Como parte de uma possível melhoria é preciso considerar de um lado aspectos como clima, aquecimento global e consumo de carbono. De outro, a qualidade da ocupação humana, a preservação de florestas nativas e a preservação de mananciais, principalmente para abastecimento da população. Além disso, a preservação de mananciais vincula-se também ao aproveitamento de outras finalidades, como geração de energia, criação de peixes e outros seres aquáticos, usados na alimentação. Entender o que é, e qual a abrangência do Sistema Nacional de Unidades de Conservação (SNUC), as possibilidades do manejo 
e a necessidade de preservar Áreas de Relevante Interesse Ecológico (ARIE) é um processo que demanda estudo e análise, mensuração, conhecimento de tecnologias específicas e o uso de laboratórios apropriados. Além disso, é preciso considerar a localização dos mananciais ou de outros tipos de unidade de conservação, em relação aos centros urbanos, principalmente grandes aglomerados, cuja concentração por vezes atua como um elemento fortemente poluidor do solo e das águas (mananciais), requerendo controle apropriado e leis especiais para evitar a degradação de espaços e contribuindo para a formação de ambientes humanos saudáveis e sustentáveis.

\section{- Recursos Hídricos}

Foram desenvolvidos 12 trabalhos de recursos Hídricos, contribuindo 12,9\% do total dos trabalhos desenvolvidos (Tabela 4.1) Os recursos hídricos são importantes como potencial de desenvolvimento e, portanto, merecem atenção como elemento vital do meio ambiente. Não há vida sem água. Por isto para utilizá-los é preciso tratá-los em termos de aproveitamento de recursos múltiplos, sem poluí-los. Nesse sentido, cabe à Gestão Ambiental controlar essa utilização e, também os níveis de poluição, os sistemas de distribuição, os desperdícios e as perdas. Por vezes inclui-se como recursos hídricos o setor de saneamento básico, distinguindo os serviços de água, esgoto e drenagem, juntamente com os tratamentos necessários para atender aos requisitos da Saúde Ambiental.

Para controlar a poluição desses recursos, legislações ambientais específicas foram aprovadas pelos poderes públicos, nas áreas federal, estadual e municipal. Além disso, para a aprovação de projetos industriais exige-se que a empresa providencie um primeiro nível de tratamento de efluentes, antes que esses sejam despejados em rios e córregos. Com este tipo de tratamento, pode-se, por exemplo, praticar o reuso das águas, para finalidades outras que não o abastecimento, com economia para o sistema 
uso dos recursos hídricos. Há países em que o reuso das águas é gerido por um sistema próprio, paralelo àquele de águas limpas e para abastecimento. A amplitude de alternativas permite repensar como enfrentar a escassez de água, uma realidade na metrópole de São Paulo, e em outras regiões, como trabalhar o uso múltiplo dos recursos hídricos, inclusive águas subterrâneas, otimizando-os e poupando-os.

- Poluição e transporte

O transporte, como meio necessário à circulação de pessoas e mercadorias, à troca de produção e serviços tem uma posição ímpar na Gestão Ambiental e contribuíram a trabalhos finais (Tabela 4.1). Primeiro porque permite a aproximação entre povos diferentes, que se encontram em distintos estágios de desenvolvimento, contribuindo-se em importantes pontos de contato não só para a comercialização, mas também para a troca de conhecimentos e de tecnologias.

Destaca-se o transporte público, voltado para o uso coletivo e operado pelo governo, e o transporte individual, merecendo ambos, investimentos públicos em infra-estrutura, aqueles, também em operação do sistema, ainda que os dois tipos sejam focos da gestão ambiental. No âmbito de estudos destacam-se os meios de transporte, os combustíveis e os impactos ambientais. Sejam os sistemas de transporte por barcaça em canais, sejam sobre trilhos ou terrestres sobre pneus, ou ainda, os aéreos, há especial interesse nos respectivos impactos sobre o meio ambiente, com geração de maior ou menor poluição. Esses meios, por sua vez carregam pessoas, mercadorias, entre as quais, produtos perigosos. Há necessidade de controle dos impactos negativos, o que requer o estudo dos tipos de combustíveis utilizados. 
- Educação Ambiental

A educação ambiental como processo na formação de cidadãos e para a resolução de problemas enfrentados em seu meio ambiente, merecem enfoques aprofundados, conforme demonstrado em cinco trabalhos desenvolvidos (Tabela 4.1). Cidadãos educados podem neste campo colaborar para uma Gestão Ambiental mais eficaz e com menor custo em seu município. Destacam-se assim os conhecimentos necessários na área da biofísica, nas áreas sócio-ambientais e econômicas, bem como da cultura e da psicologia.

Como pode se perceber para a solução de problemas, conforme os respectivos campos de influência, é preciso contar com conhecimentos interdisciplinares, nas propostas de soluções. Daí a importância da educação ambiental no preparo de cidadãos conscientes, para 0 enfrentamento de problemas de suas comunidades e portanto responsáveis pela formação de multiplicadores desse conhecimento, construído a partir de diferentes saberes e enriquecido por diferentes visões e perspectivas atuais e futuras. Na Gestão Ambiental a atuação da educação ambiental esta voltada principalmente para a prevenção, promoção e recuperação ambiental tendo como objetivo final alcançar melhoria da qualidade de vida para todos.

- Participação Comunitária

Dentre os quatro trabalhos desenvolvidos, $4,3 \%$ foram referentes a participação comunitária (Tabela 4.1). Ao longo da formação dos núcleos urbanos a participação da população veio se desenvolvendo lentamente na Gestão Ambiental embora esta história tenha alguns marcos importantes como a participação em audiências públicas, nos conselhos e em regiões de bacias hidrográficas em seus respectivos comitês. Essa experiência é mais restrita quando se fala de conjuntos habitacionais, se comparada com outros 
países, em que são tratadas como questões de desenvolvimento de comunidades residenciais que precisam de moradia, mas também de alfabetização e capacitação para a produção de serviços. À medida que são grandes os contrastes entre desenvolvidos e subdesenvolvidos, ricos e pobres, a necessidade de participação da população em vários tipos de projetos comunitários torna-se cada vez mais importante. Isto já é amplamente reconhecido em nível das políticas públicas, na Constituição e em outras leis como: a lei federal do Estatuto da Cidade - Lei 10257/01 - por meio da qual os municípios devem elaborar seus planos diretores com suas políticas urbanas, com a participação da comunidade. Mister se faz, portanto, conhecer a questão, responsabilidades e direitos e, organizar as lideranças locais para gerar uma força sinérgica que seja propulsora do desenvolvimento almejado por meio da educação ambiental e vista justamente por essa função, como um processo de educação política que busca a melhoria da qualidade de vida da humanidade.

\section{- Energia}

Os três trabalhos desenvolvidos sobre o tema energia $(3,2 \%)$ objetivavam compreender o panorama do setor no Brasil, provocando debates sobre as possibilidades de equilíbrio da matriz energética, destacando os tipos de produção e o balanço de energia para atender ao mercado nacional. Entender esse panorama é uma questão básica, pois é preciso conhecer os recursos potenciais para utilização no mercado e explorar as possibilidades do uso de energias alternativas (eólica, solar, biomassa) face aos impactos no meio ambiente avaliados por tipo de fonte, como as tradicionais: hidrelétrica, gás, nuclear, termoelétrica. Uma comparação entre essas diferentes fontes de energia torna-se um objetivo a perseguir, distinguindo as vantagens e desvantagens específicas de cada tipo de energia, em termos de produção, eficiência de serviços, custos acessíveis e satisfação do usuário, com atendimento ininterrupto, para os diferentes tipos de atividades: residenciais, industriais, comerciais e de serviços. 
- Certificação/Normatização

Os trabalhos $(\mathrm{n}=2)$ na Tabela 4.1 mostram as preocupações tanto com a qualidade, como com o meio ambiente, o que, desde 1980 vem sendo enfatizado nos processos de certificação. Em um primeiro momento observou-se a preocupação em garantir aos clientes e potenciais consumidores ou usuários de serviços, a qualidade do produto e do processo utilizados para, por sua vez, manter a qualidade do meio ambiente, sem degradá-lo. É importante entender essa nova visão, principalmente quando se trata de estabelecer relações internacionais, nas quais as normas ISO têm a missão de transferir alta confiabilidade a produtos e a processos de produção, controlando os impactos negativos ao meio ambiente, de modo a permanecer dentro de indicadores acordados em nível mundial.

4.2.2 Características do corpo discente para os cursos: CEGA 1 - CEGA13

O objetivo desta etapa da pesquisa foi agrupar as características do corpo discente para todos os 13 cursos CEGA, obtendo desta forma um perfil médio dos alunos avaliados. A análise agrupada reuniu dados de formação profissional, gênero, local de atuação quando do início do curso, atuação na área ambiental, setor de atuação e ano de conclusão do primeiro curso de graduação. 


\section{Formação profissional}

Figura 4.27 - Formação profissional dos ex-alunos CEGA 1 - CEGA 13

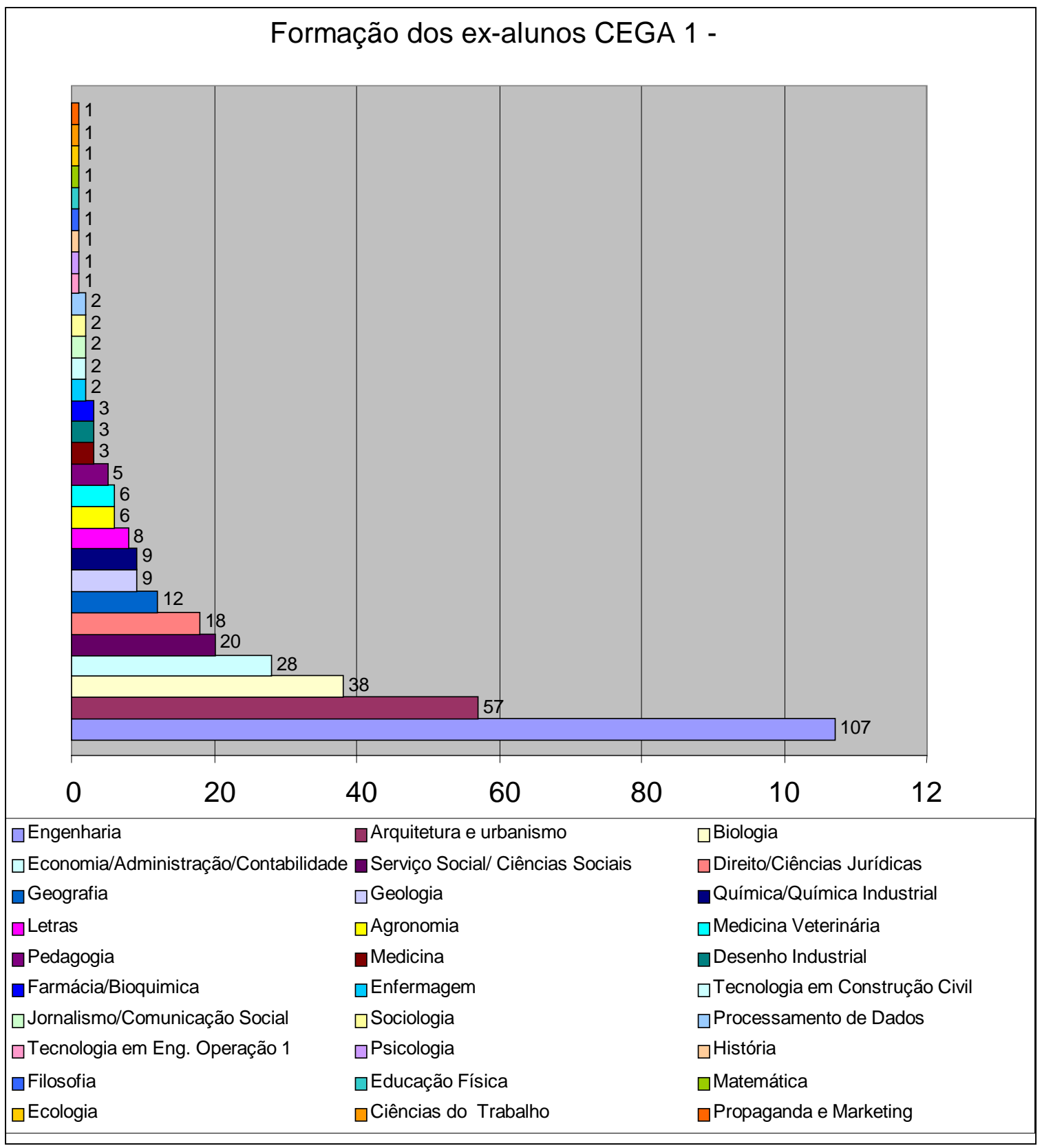


A análise da figura 4.27 indicou um contingente grande de formações ( $n=30)$ das mais diversas presentes nos cursos CEGA, denotando claramente a existência da multidisciplinaridade. Algumas formações, entretanto, merecem comentários adicionais: Embora o Curso de Especialização em Direito Ambiental, seja também oferecido pelo NISAM, a presença de profissionais das áreas de Serviço e Ciências Sociais, apontaram uma maior participação das prefeituras e das ONGs nos processos de capacitação de seus membros. Os profissionais da área de Agronomia presentes no curso poderiam ser incentivados ainda mais a participar, visando uma atuação mais presente na gestão ambiental das interfaces urbano-rural. As áreas de Jornalismo e Comunicação Social, além de já estarem presentes, possuem potencial para ampliação de participação tendo em vista a importância cada vez maior da mídia nas ocorrências ambientais quer positivas quer negativas.

- Alunos por gênero

Figura 4. 28 - Variação no gênero CEGA 1 - CEGA 13

\section{VARIAÇÃO NO GÊNERO}

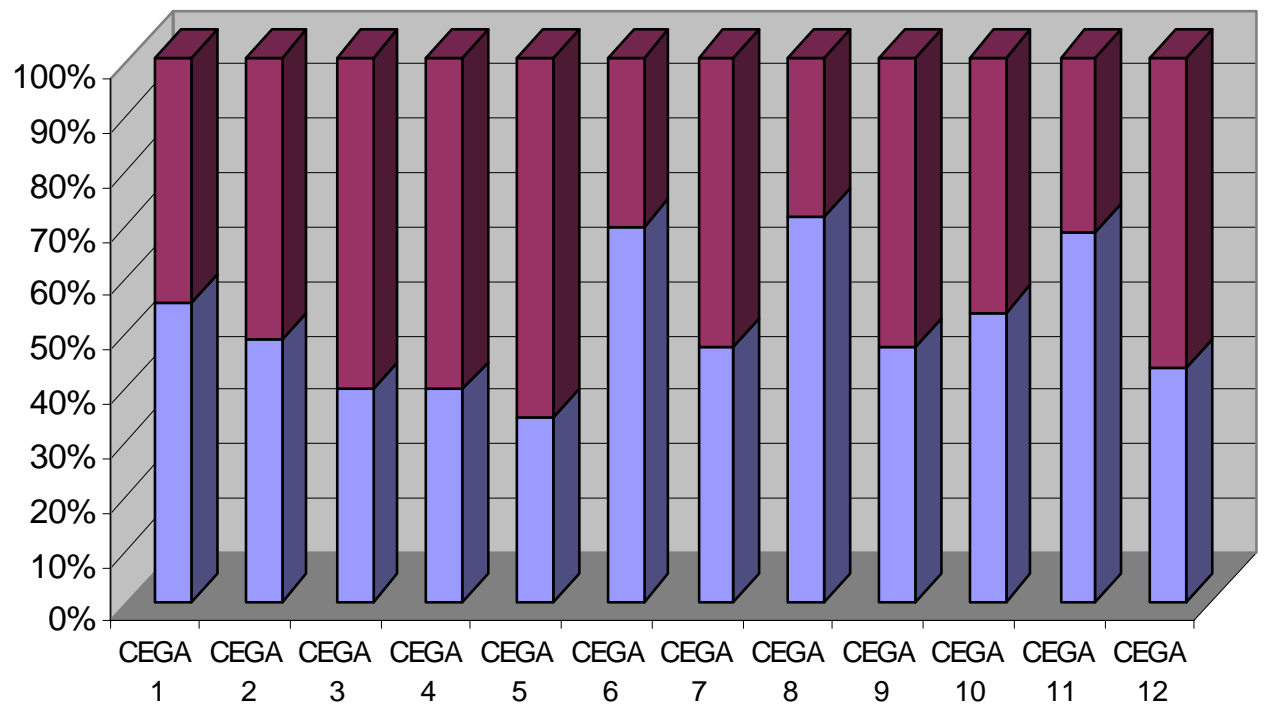


- Local de trabalho/atuação quando do início do curso

Os 408 alunos que se matricularam nos cursos CEGA de 1 a 13, atuavam profissionalmente em 39 municípios, sendo 38 situados no Brasil e 1 situado na Colômbia, município Ciudad-Bolivar. A concentração de atuação foi em apenas quatro municípios: São Paulo, Jundiaí, Bauru e Guarulhos. Os demais estavam distribuídos por grande parte do Estado de São Paulo, como demonstram as figura 4.29 e 4.30 a seguir.

Figura 4. 29 - Local de atuação dos ex-alunos - CEGA 1 - CEGA 13

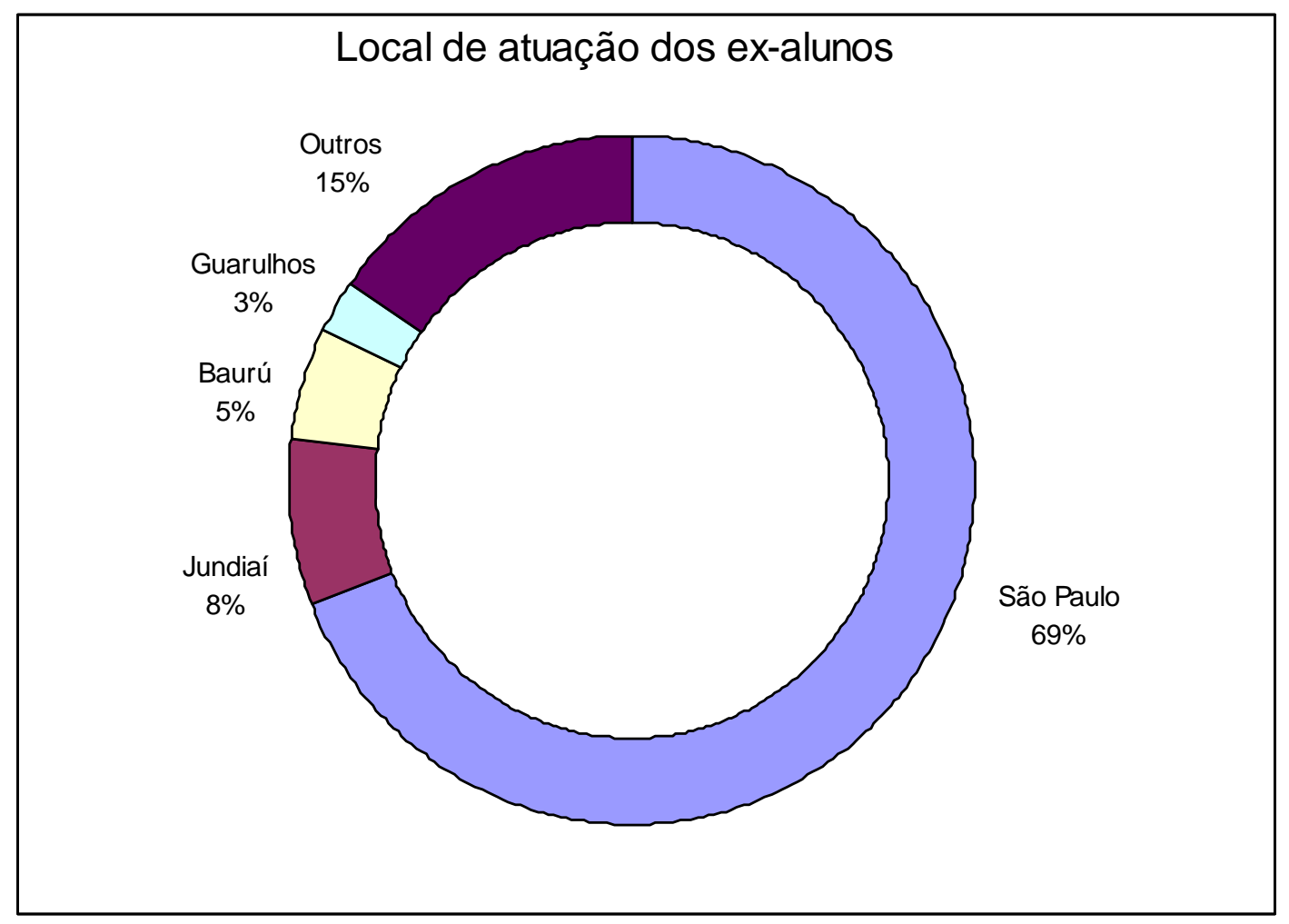


Figura 4. 30 - Municípios de atuação dos ex-alunos

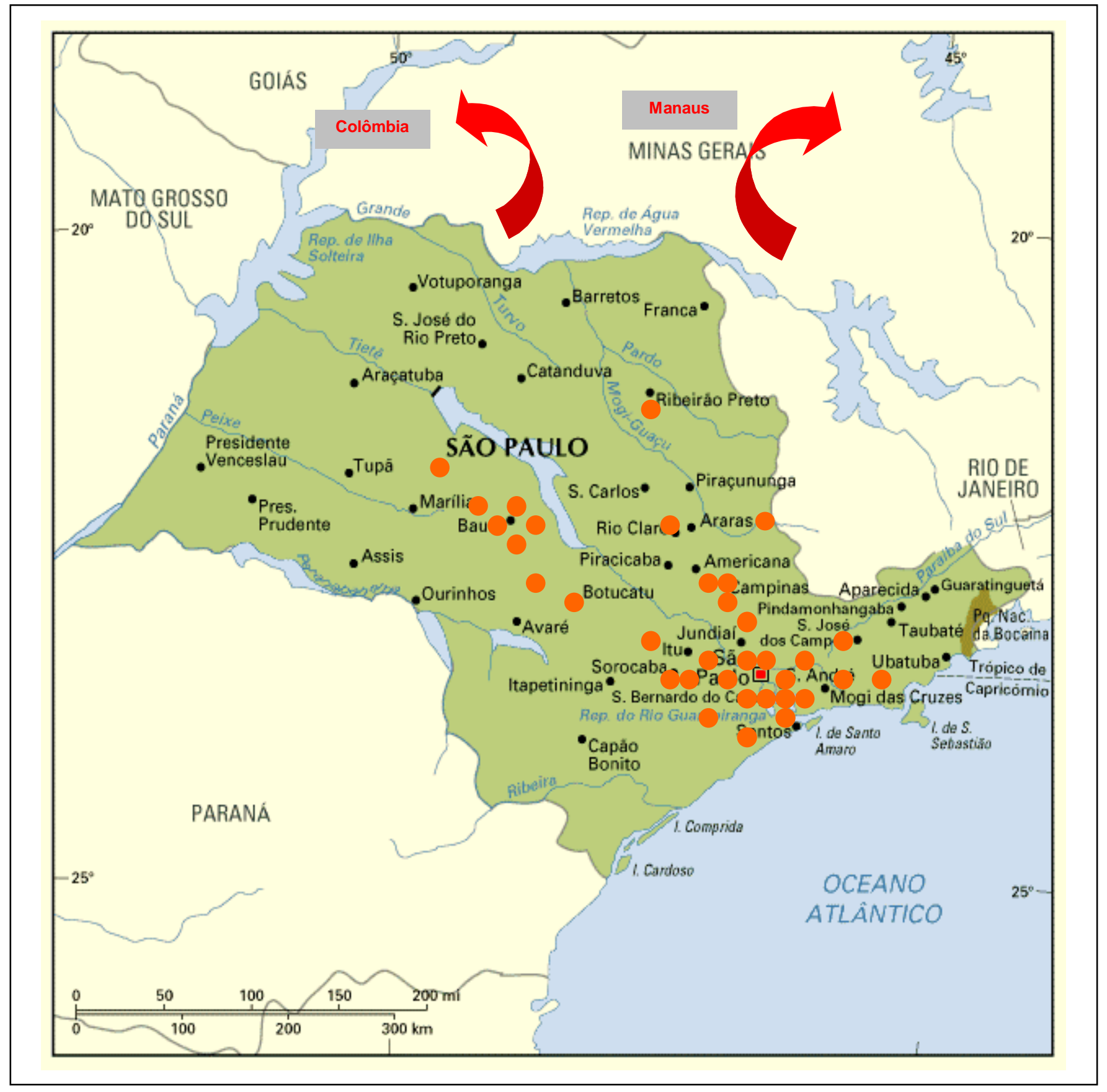


- Atuação na área ambiental

Figura 4. 31 - Atuação na área ambiental CEGA 1 - CEGA 13

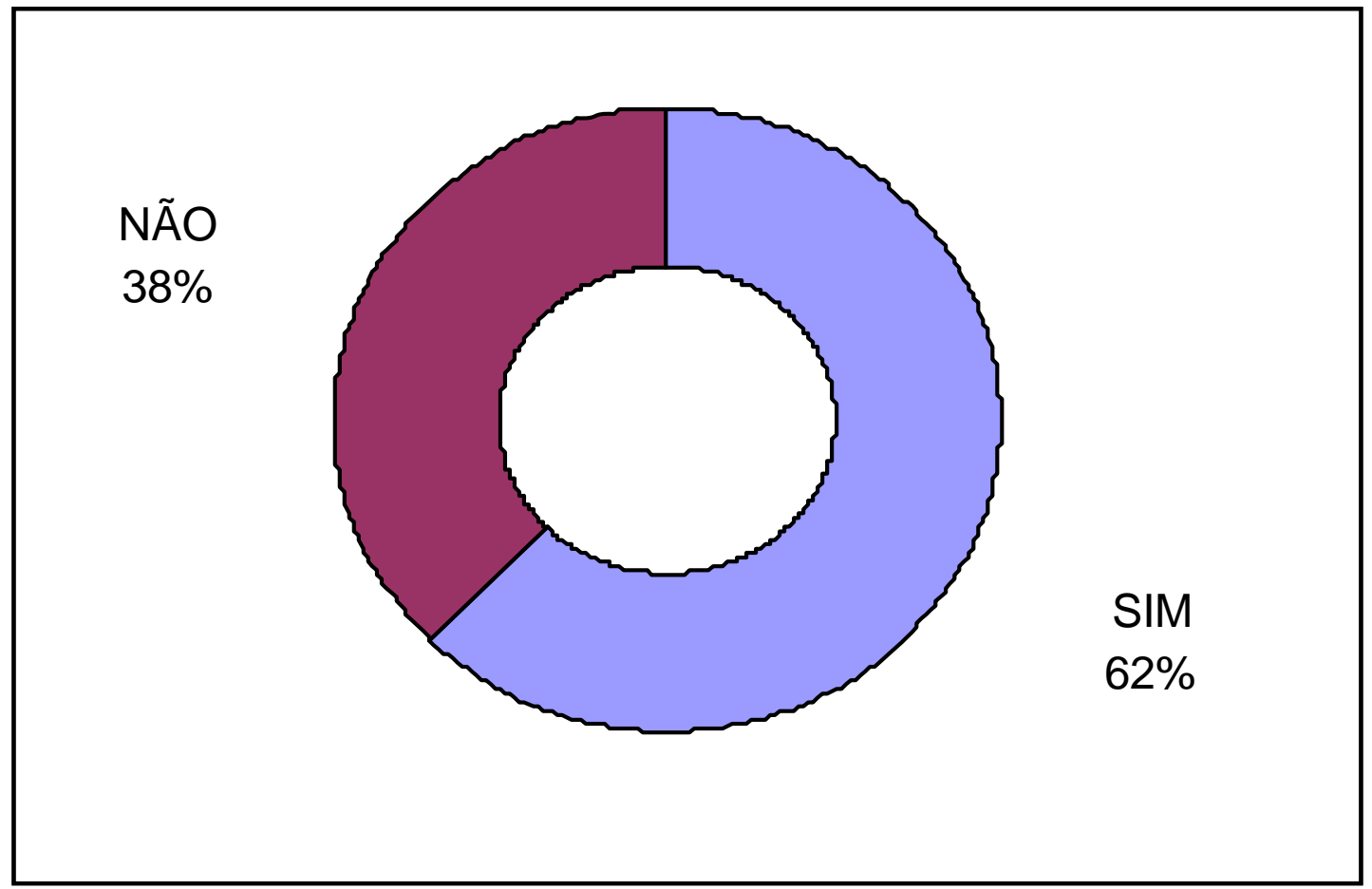

A análise do gráfico 4.31 indicou que a atuação anterior requisitou uma especialização na área ambiental para aprimorar e aprofundar conhecimentos, enquanto que aqueles que ainda não atuavam, buscaram uma capacitação para futuramente poderem atuar. 
- Setor de atuação

Figura 4. 32 - Setor de atuação CEGA 1 - CEGA 13

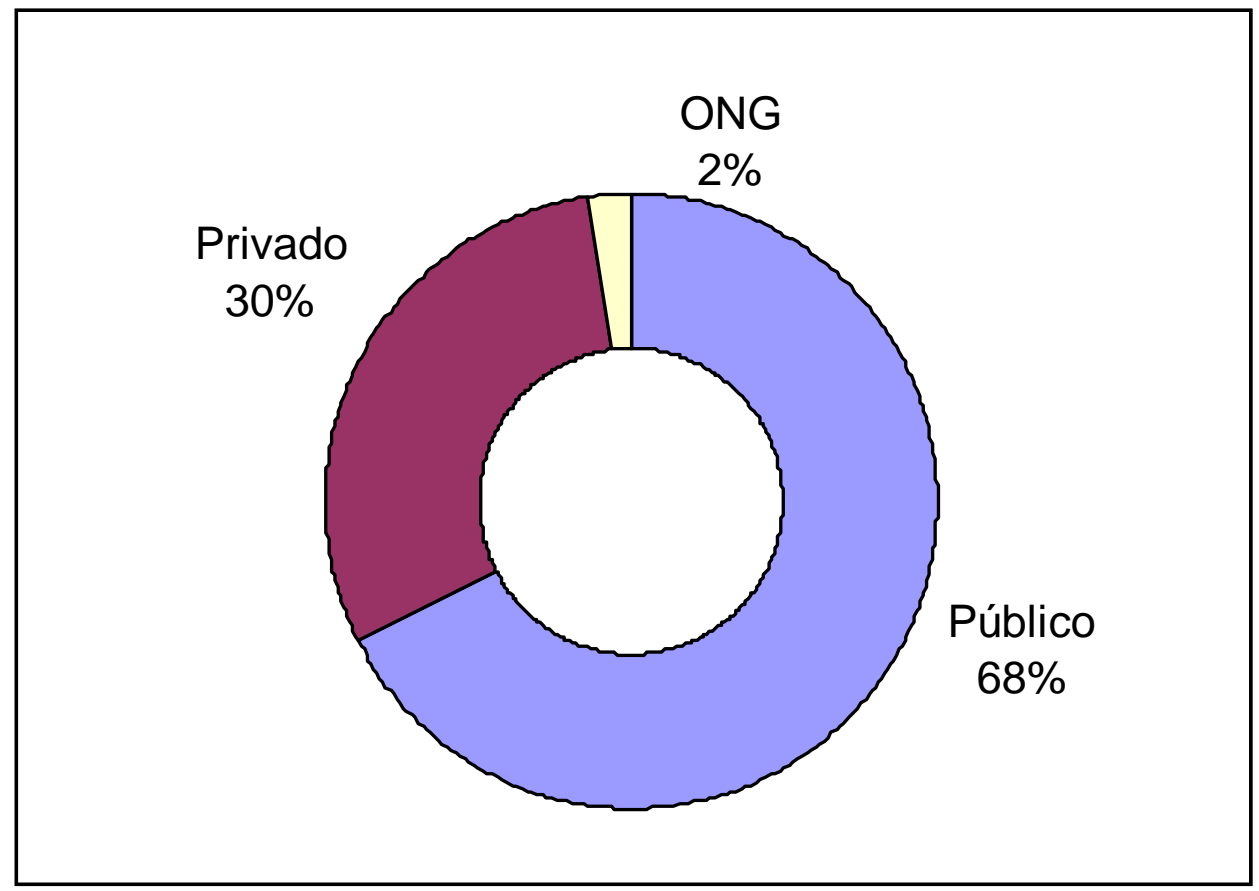

Com relação ao setor de atuação ficou clara a participação preponderante do setor público no processo decisório e no processo gestor do ambiente urbano. A criação dos cursos CEGA em 1995 abriu a possibilidade de um enorme contingente de técnicos de todas as áreas ligadas relacionadas ao ambiente, obterem capacitação na área. Isto explicou a maior procura e consequentemente o maior número de alunos ingressantes provenientes destas áreas. A Figura 4.32 apresentou quantitativos agrupados de todos os cursos, a maior participação do setor público foi também explicada por 4 cursos dentre os 13 aqui analisados, com participação total - 100\% dos alunos - provenientes do setor público. Estes cursos foram realizados por meio de convênios com a Secretaria Municipal do Verde e do Meio 
Ambiente, da CETESB, da SABESP, da Secretaria Municipal da Saúde e da ABES - Associação Brasileira de Engenharia Sanitária e Ambiental.

A procura por cerca de $30 \%$ dos profissionais do setor privado indicou uma necessidade deste setor se autocapacitar para atender as solicitações e a demanda de serviços por parte do setor público. Considerando a crescente procura por serviços terceirizados, a participação de profissionais do setor privado deve crescer nos futuros Cursos de Gestão Ambiental. A participação de técnicos de ONGs, é em parte explicada pela possibilidade garantida nas inscrições para profissionais vindos destas instituições. Esta decisão foi tomada pelo corpo de coordenação, tendo em vista a importância cada vez maior das ONGs nas assessorias a órgãos dos setor público e privado que atuam na área ambiental. Desta forma, os cursos CEGA, contribuem também para capacitar esta parcela importante da sociedade.

\subsection{Resultados da $2^{\mathrm{a}}$. Etapa da pesquisa - Entrevistas}

As Figuras a seguir indicam o resultado da tabulação dos dados de todas as questões do roteiro de entrevista aplicado entre maio e junho de 2002, bem como, as análises dos resultados agrupados e a comparação destes resultados com aqueles da $1^{a}$. etapa da pesquisa, ou seja, as características profissionais dos ex-alunos, antes e depois de cursarem os CEGA. 
- Atuação dos alunos entrevistados no momento presente

Figura 4.33 - Atuação dos entrevistados

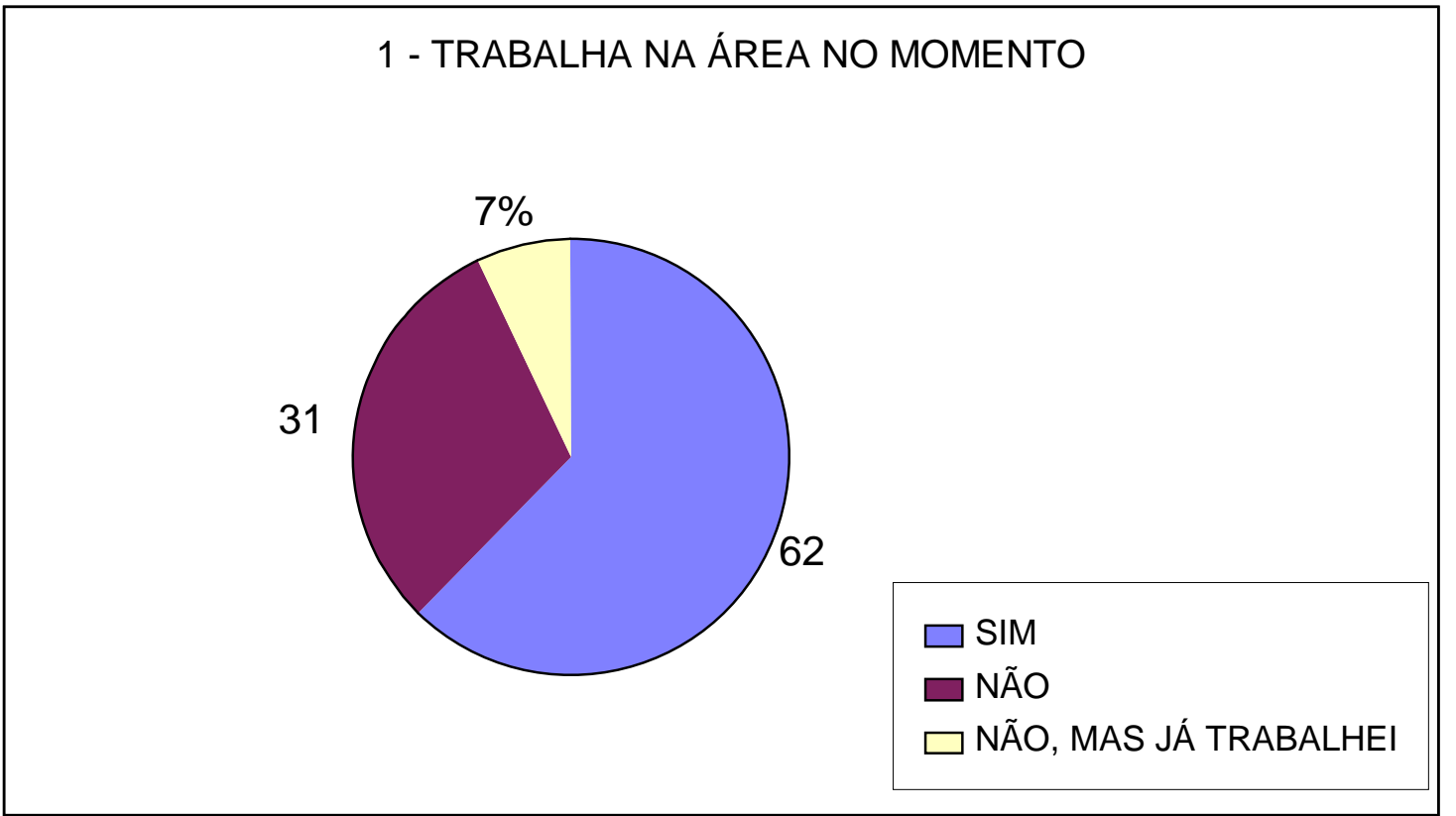

Verifica-se que $69 \%$ dos alunos estão ou estiveram presentes na área ambiental, tendo havido uma elevação de $8 \%$ no percentual de participação de profissionais que atuam ou já atuaram na área ambiental, após a conclusão do curso. Ao se comparar o resultado desta questão com a situação inicial dos ex-alunos, (figura 4.1), observou-se que houve uma elevação desta participação, de $62 \%$ para $70 \%$. A parcela de $7 \%$ dos profissionais que já atuaram, mas não atuam mais na área ambiental no momento, pode ser explicada pelas transferências de funções e cargos na administração pública e principalmente quando das mudanças de governo. Especificamente nos caso dos cursos CEGA, uma parcela dos funcionários da Secretaria Municipal do Verde e do Meio Ambiente, que cursaram estes cursos entre 1995 e 1997, foi transferida de suas funções na área ambiental 
para suas funções de origem na administração pública, porém fora da área ambiental.

- Setores nos quais os entrevistados trabalham no momento

Figura 4.34 - Setores de atuação

\subsection{TRABALHA NA ÁREA NO MOMENTO? SE SIM, ONDE?}

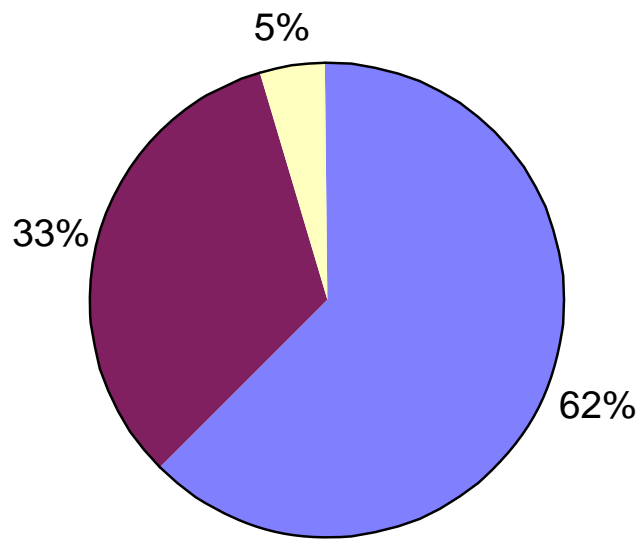

Os alunos entrevistados atuavam no início do Curso 68\% no setor público, $30 \%$ no setor privado e $2 \%$ em ONGs ( figura 4.2). Observou-se uma ampliação de profissionais atuando no setor privado, bem como em ONGs, denotando o resultado das parcerias entre estes setores e também a maior participação da sociedade civil neste processo. O setor público, entretanto, ainda foi o maior empregador de técnicos na área ambiental e especificamente no universo desta pesquisa, ele empregou cerca de duas vezes a quantidade de técnicos do setor privado. 
- Alteração na forma de pensar dos entrevistados

Figura 4.35 - Forma de pensar dos alunos após a conclusão do CEGA

1.2 - APÓS A CONCLUSÃO DO CEGA AVALIE A SUA FORMA DE PENSAR

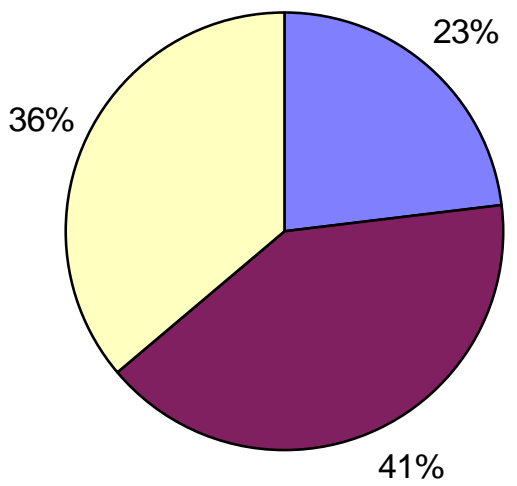

Esta questão procurou identificar o grau de mudança na forma de pensar dos entrevistados após terem concluído o CEGA. Para cerca de $77 \%$ dos entrevistados, o curso produziu mudanças na forma original de pensar, sendo que para $41 \%$ do total, estas mudanças foram acentuadas, confirmando uma das hipóteses iniciais desta pesquisa e reafirmando a importância desta capacitação na vida profissional destes ex-alunos (Figura 4.3). 
- Mudanças na atuação dos entrevistados após a conclusão do CEGA

Figura 4.36 - Mudanças na atuação dos entrevistados após a conclusão do CEGA

\section{2 - APÓS A CONCLUSÃO DO CEGA AVALIE A SUA ATUAÇÃO NO LOCAL DE TRABALHO}

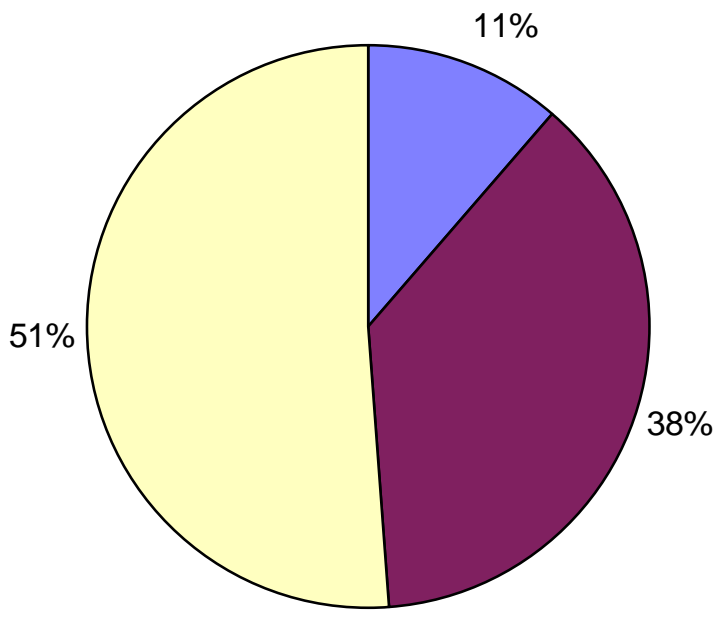

O curso alterou a atuação no local de trabalho para cerca de $89 \%$ dos entrevistados. Ao se comparar este resultado com o da questão anterior, notou-se que o conhecimento novo adquirido para $77 \%$ dos entrevistados, pode ter sido o agente destas mudanças aqui apontadas. Os resultados das mudanças na atuação profissional dos entrevistados também confirmaram uma das hipóteses levantadas, de que houve mudanças na forma de atuação profissional dos ex-alunos em seus locais de trabalho. 
- Opinião dos entrevistados sobre a contribuição do curso para a ascensão profissional na carreira

Figura 4.37 - Opinião dos entrevistados sobre a contribuição do curso para a ascensão profissional na carreira

1.4 - VOCÊ ACHA QUE SUA ESPECIALIZAÇÃO EM G.A . CONTRIBUIU PARA A ASCENÇÃO PROFISSIONAL NA SUA CARREIRA

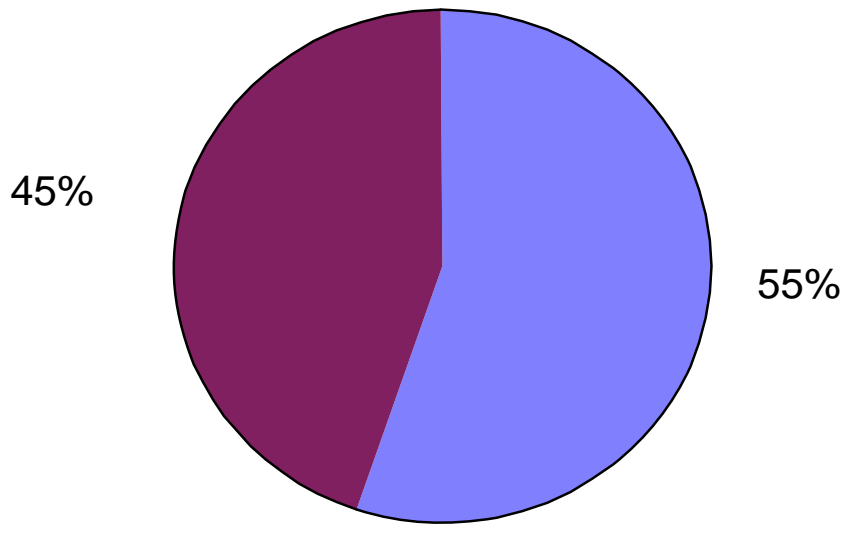

A avaliação das duas questões anteriores (Figuras 4.3 e 4.4 ) complementaram o resultado desta questão, ou seja, $77 \%$ dos entrevistados mudaram a forma de pensar e 89\% mudaram a atuação no local de trabalho sendo que esta alteração provocou ascensão profissional para 55\% dos alunos (Figura 4.5). Ao se considerar que mudanças de atitude e atuação são na verdade a mola propulsora das mudanças na sociedade, os Cursos de Especialização tem sido agente desta alteração para cerca de 500 profissionais já capacitados pelos Cursos desde 1995. Esta questão possibilitou ao entrevistado se quisesse justificar a sua opção. 
- Opinião dos entrevistados sobre as conseqüências de sua capacitação em gestão ambiental

Figura 4.38 - Impacto do conhecimento dos alunos nos locais de trabalho.

1.5 - PARA A SUA INSTITUIÇÃO QUAL FOI A CONSEQUENCIA DE TE-LO COMO PROFISSIONAL CAPACITADO EM G.A.

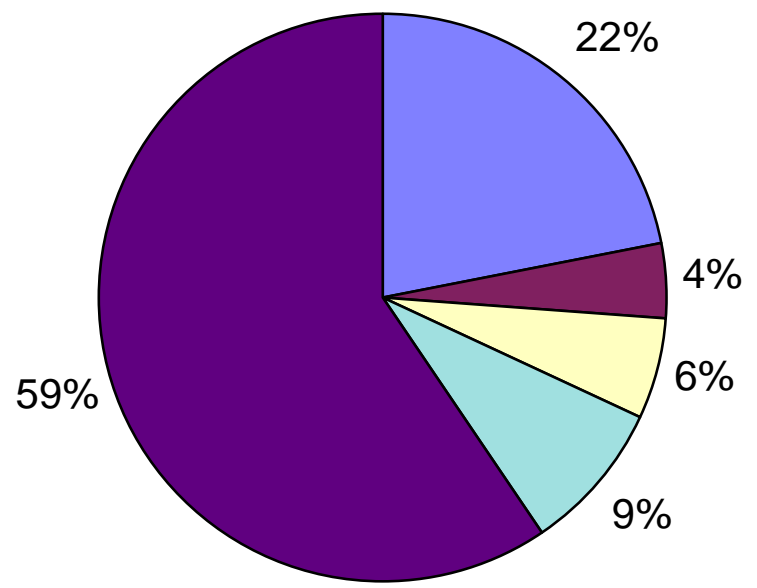

$\square$ EXPANSÃO DO SETOR

$\square$ CRIAÇÃO DE NOVO SETOR

- OUTRO
๑AUMENTO DE FUNCIONÁRIOS

$\square$ CERTIFICAÇÃO

Avalia-se o impacto nos locais de trabalho, da capacitação em gestão ambiental em diversos aspectos conforma Figura 4.5. Cerca de $41 \%$ dos respondentes apontou aspectos positivos e de certa forma impactantes em uma empresa, como expansão das atividades do setor ambiental na empresa; aumento no número de funcionários deste setor; a criação específica de um setor ambiental que antes não existia; a busca por algum tipo de certificação ou cumprimento da legislação ambiental vigente. 
Os alunos que optaram pela opção "outro" explicitaram os seus motivos que foram agrupados em três categorias: conscientização de colegas de trabalho; aumento das possibilidades profissionais da empresa e o início da preocupação da própria empresa em atender as questões ambientais.

- Difusão dos conhecimentos dos alunos para outras pessoas

Figura 4.39 - Difusão dos conhecimentos adquiridos no CEGA

\section{6 - APÓS O CEGA, VOCÊ LEVOU OS SEUS CONHECIMENTOS PARA OUTRAS PESSOAS?}

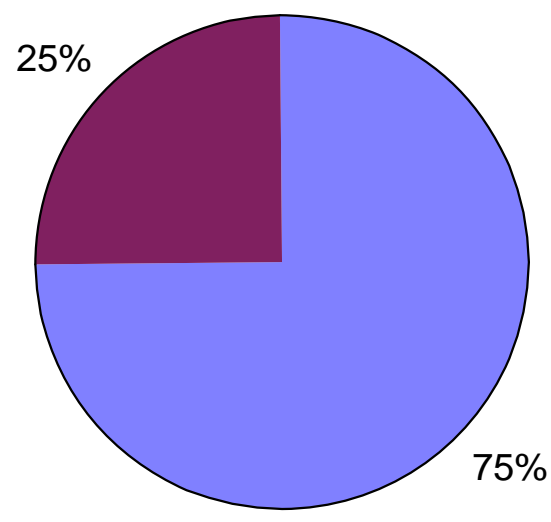


Forma de difusão do conhecimento

Figura 4.40 - Forma de difusão dos conhecimentos.

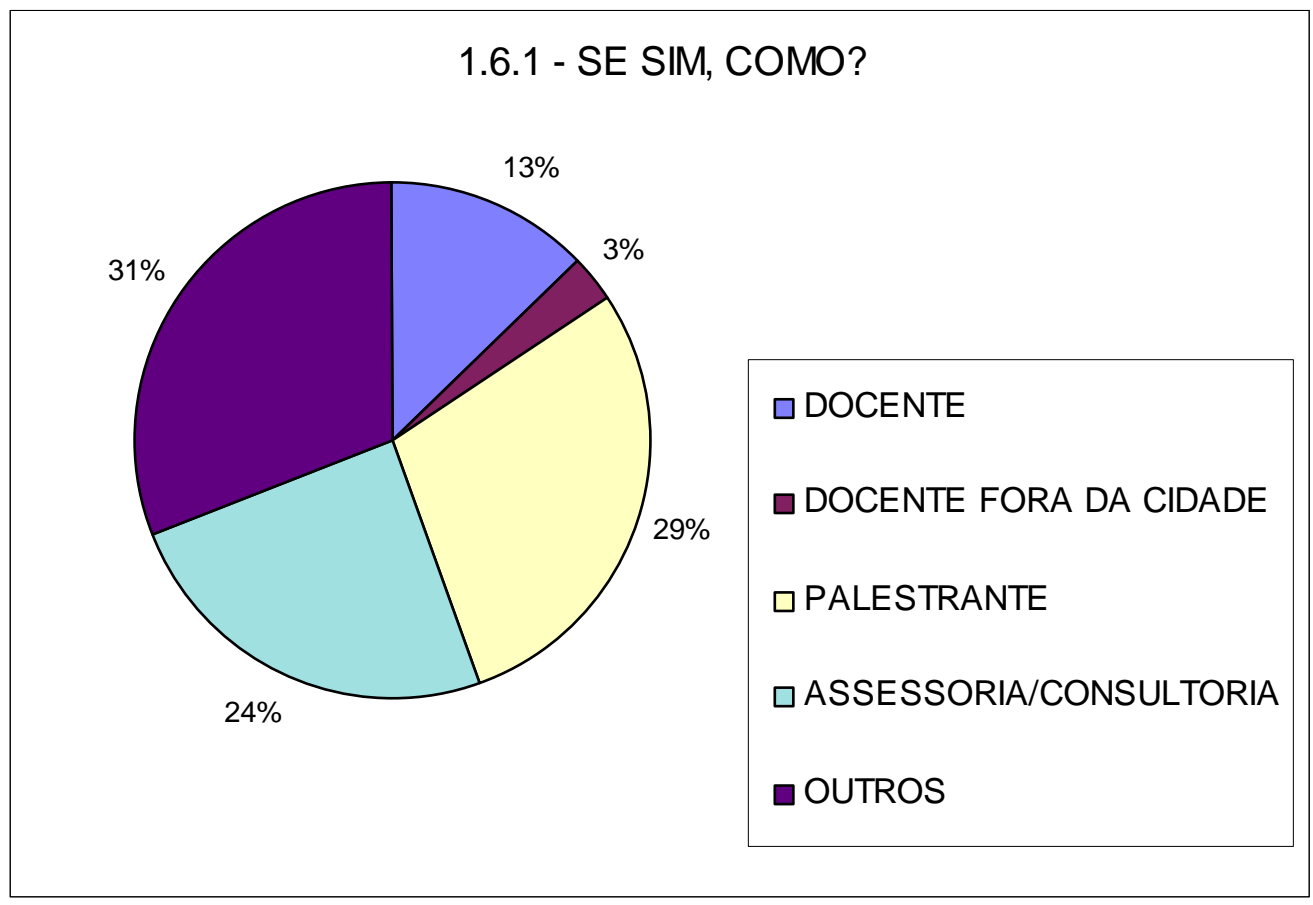

De acordo com a Figura 4.40 para os $75 \%$ dos entrevistados que afirmaram ter atuado na transferência do conhecimento adquirido em CEGA, cerca de $45 \%$, compartilharam este conhecimento na forma direta de transmissão, ou por meio de aulas formais ou por meio de palestras. Cerca de $24 \%$ dos $75 \%$, o fizeram de forma indireta, por meio de assessorias ou de consultorias. Para os $31 \%$ restantes, também houve algum tipo de transmissão de conhecimento, porém não listadas no roteiro das entrevistas, que pode ter sido expresso por meio de artigos técnicos ou em conversas informais.

Os alunos que optaram pela resposta "outro" explicitaram os seus motivos e foram agrupados em três categorias: auxílio informal e voluntário por meio de conversas de conscientização com colegas de trabalho da mesma empresa e de outras empresas que atuam em área afins; entrevistas à mídia em nome da empresa ou em testemunho próprio e ministrando aulas 
isoladas no âmbito da temática ambiental, relacionadas à especificidade da empresa.

Os entrevistados que optaram pela opção "não", apontada na questão 1.6.2 do roteiro de entrevista (ANEXO 5), justificaram a opção por não levar os seus conhecimentos a outras pessoas após a conclusão do CEGA, pelos seguintes motivos: não trabalha atualmente na área ambiental; não tem interesse atual pela área ambiental e um terceiro grupo afirmou levar o conhecimento adquirido apenas de modo informal.

Ora, levar o conhecimento de modo informal, é na verdade uma alternativa para a transmissão do conhecimento e assim este terceiro grupo de entrevistados que afirmou não levar o conhecimento adquirido em CEGA para outras pessoas, o faz em caráter informal. 
- Importância do conhecimento obtido no CEGA para a atuação profissional dos ex-alunos no momento presente.

Figura 4.41 - Importância do conhecimento obtido no CEGA para a atuação profissional dos ex-alunos no momento presente.

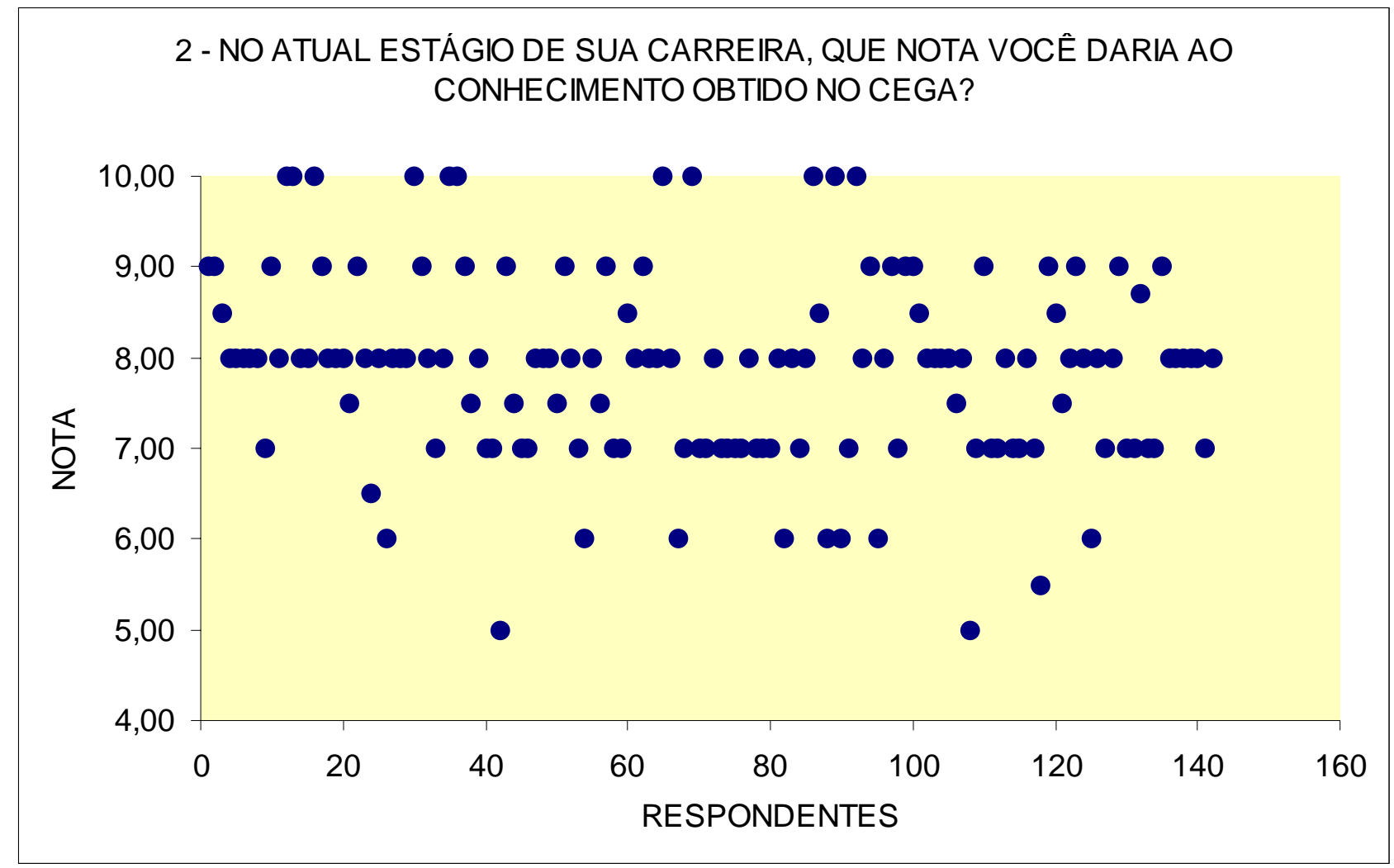

A avaliação das respostas desta questão indica o valor 8,0 como o indicador estatístico moda e média e o valor 1,06 para o desvio padrão, denotando elevada confiabilidade e reduzida dispersão em torno da média. Para efeitos de avaliação do programa CEGA, as respostas dos entrevistados indicam que após um período que variam de 1 a 7 anos, os profissionais capacitados continuaram utilizando profissionalmente os conhecimentos adquiridos.

O grupo de entrevistados que respondeu à questão 2 do roteiro de entrevista (ANEXO 5), justificou as suas notas para os conhecimentos obtidos nos CEGAs agrupando-as em três categorias: (1) Aqueles que justificaram as 
notas elevadas por razões de conteúdo. (2) Aqueles que justificaram as notas mais baixas por razões de conteúdo. (3) Aqueles que justificaram as notas mais baixas por razões de forma e não de conteúdo. Para a primeira categoria, foram apontadas as seguintes justificativas: $O$ curso foi excepcionalmente bom; $O$ curso foi muito bom, mas possui algumas ressalvas; Houve muito conhecimento adquirido e relevante para a minha vida profissional. Para a segunda categoria, foram apontadas as seguintes justificativas: Falta de didática de alguns professores; Excesso de abordagens teóricas e carências de abordagens práticas. Para a terceira categoria, foram apontadas as seguintes justificativas: Dificuldade de estacionamento; Falta de contato com os professores quando o curso foi ministrado fora de São Paulo; Reduzida carga horária.

Nota-se que os entrevistados que justificaram suas notas baseadas em questões de caráter formal, portanto a terceira categoria, não compreenderam nem responderam devidamente a questão, pois a mesma refere-se à nota dada ao conhecimento obtido no curso. 
- Áreas em que o entrevistado atuou ou está atuando

Figura 4.42 - Áreas em que o entrevistado atuou ou está atuando

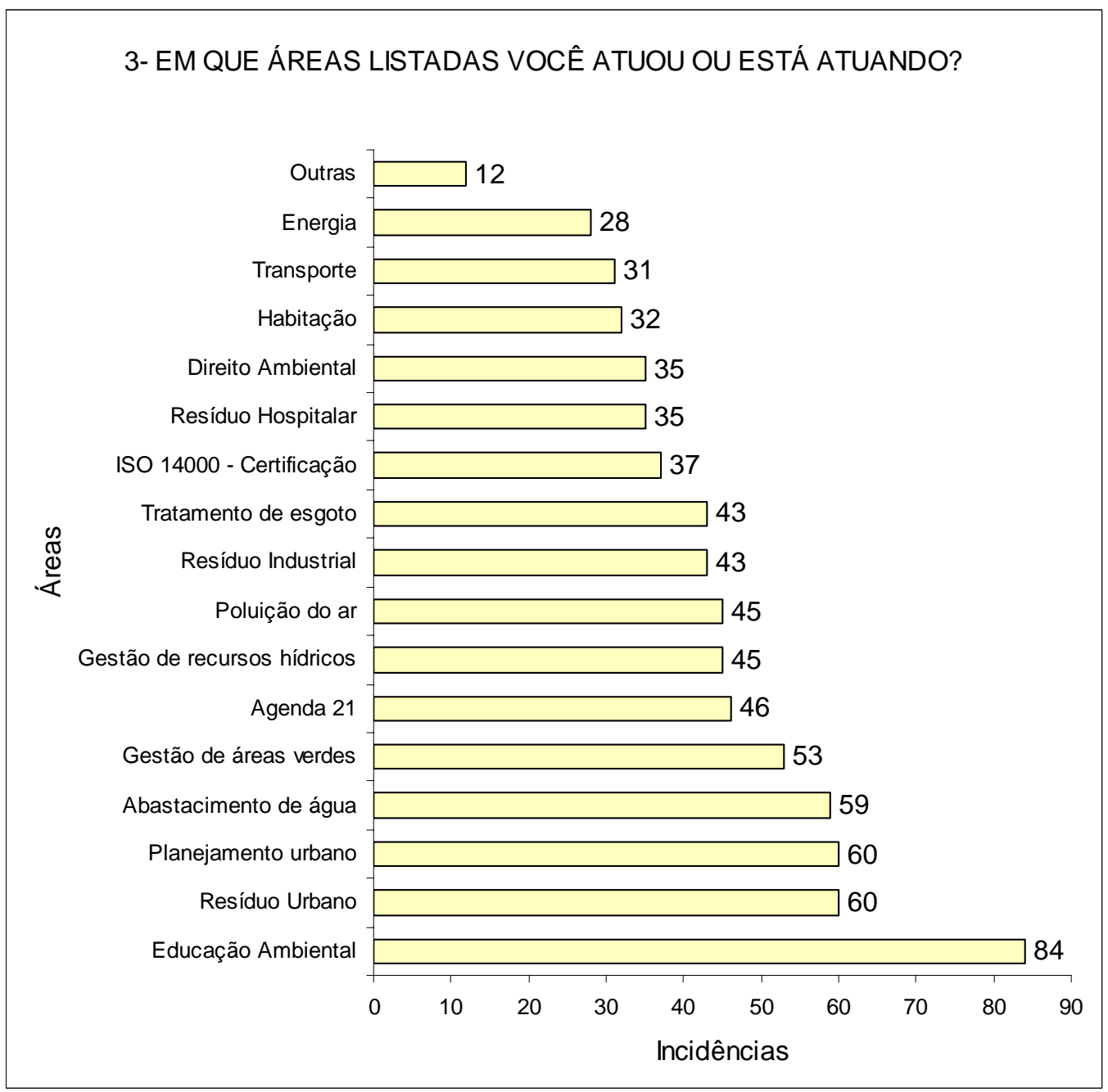

$\mathrm{Na}$ questão 3 do roteiro de entrevista (ANEXO 5), os ex-alunos podiam indicar mais de uma área de atuação em suas respostas. O objetivo desta questão foi avaliar as áreas que vêm sofrendo mais atuação por parte destes profissionais e comparar com suas áreas de interesse durante a realização do CEGA.

A educação ambiental apareceu como a área de maior atuação tendo em vista a gama variada de aplicações de conceitos de educação ambiental no 
âmbito da gestão ambiental. A educação ambiental permeia todas as demais áreas presentes na Figura 4.43 e conseqüentemente torna-se uma área de importância vital na atividade do gestor ambiental. A questão dos resíduos aparece com destaque nas preocupações dos profissionais/ex-alunos demonstrando a estreita relação entre as atuações profissionais com as temáticas envolvidas nos trabalhos finais de conclusão de curso. Os resultados da primeira etapa da pesquisa apontaram a área de resíduos como sendo a de maior procura por parte dos ex-alunos para o desenvolvimento de seus trabalhos.

É importante destacar que o resultado desta questão também mostrou a importância da educação ambiental no conteúdo programático de Gestão Ambiental, procurando relaciona-la cada vez mais com as demais questões envolvidas na área, no sentido de identificar ações educativas em cada uma destas áreas, gerando a minimização de futuros impactos.

Esta questão permitiu a opção outras áreas indicada por alguns respondentes, que deram as seguintes alternativas: engenharia de segurança do trabalho; políticas públicas; mineração e ecoturismo.

- Conteúdo a ser aprofundado e adicionado

As questões 4 e 5 do roteiro de entrevistas (ANEXO 5) indicaram alguns conteúdos que na opinião dos ex-alunos poderiam ser aprofundados e/ou adicionados nos próximos cursos. As respostas de ambas as questões agrupadas por temas apontaram os seguintes conteúdos: Direito Ambiental; Auditoria Ambiental e Planejamento Urbano.

Para a questão do Direito Ambiental, a Faculdade de Saúde Pública em conjunto com a Faculdade de Direito da USP, vêm oferecendo desde março de 2000, o Curso de Pós-Graduação Lato Sensu Especialização em Direito Ambiental, que foi estruturado e oferecido, também com base na solicitação 
de ex-alunos de cursos CEGA e CEESB, com um grande aprofundamento na área do direito. No tocante a auditoria ambiental, o interesse dos exalunos pode ser explicado em parte pela importância que a área vem despertando em técnicos de todo o país, e também devido à abrangência do mercado e aos resultados que podem ser obtidos. 


\section{CAPÍTULO 5- CONCLUSÕES}

Partindo do objetivo principal desta tese, de avaliar o impacto da atuação profissional de recursos humanos, capacitados pelos cursos de pósgraduação Lato-Sensu Especialização em Gestão Ambiental, esta pesquisa dividiu-se, do ponto de vista metodológico em duas etapas. A $1^{\text {a }}$. Etapa objetivou a identificação do perfil dos 408 ex-alunos matriculados nos cursos segundo os seguintes aspectos pessoais e profissionais: formação inicial, gênero, cidade de atuação profissional, setor de atuação profissional (Público, Privado, ONGs), engajamento profissional na área ambiental, tempo de conclusão de curso. A $2^{\mathrm{a}}$. Etapa teve três objetivos: (1) conhecer a opinião dos alunos com relação a sua atuação no mercado profissional no momento atual, à luz da capacitação realizada na área de gestão ambiental; (2) avaliar as mudanças e os impactos ocorridos na vida profissional dos exalunos, após a capacitação realizada na área de gestão ambiental; e (3) comparar, analisar e discutir os dados obtidos na $1^{\mathrm{a}}$. e $2^{\mathrm{a}}$. Etapas.

\subsection{Conclusões da $1^{\mathrm{a}}$. Etapa da pesquisa}

A avaliação dos dados referentes a $1^{\text {a }}$. Etapa desta pesquisa, discutidos no item 4.4.3 - Características do corpo discente para os cursos CEGA 1 a CEGA 13, permitiram compor o perfil do aluno típico, conforme Figura 5.1. 
Figura 5.1 - Perfil do aluno típico - CEGA 1 - CEGA 13

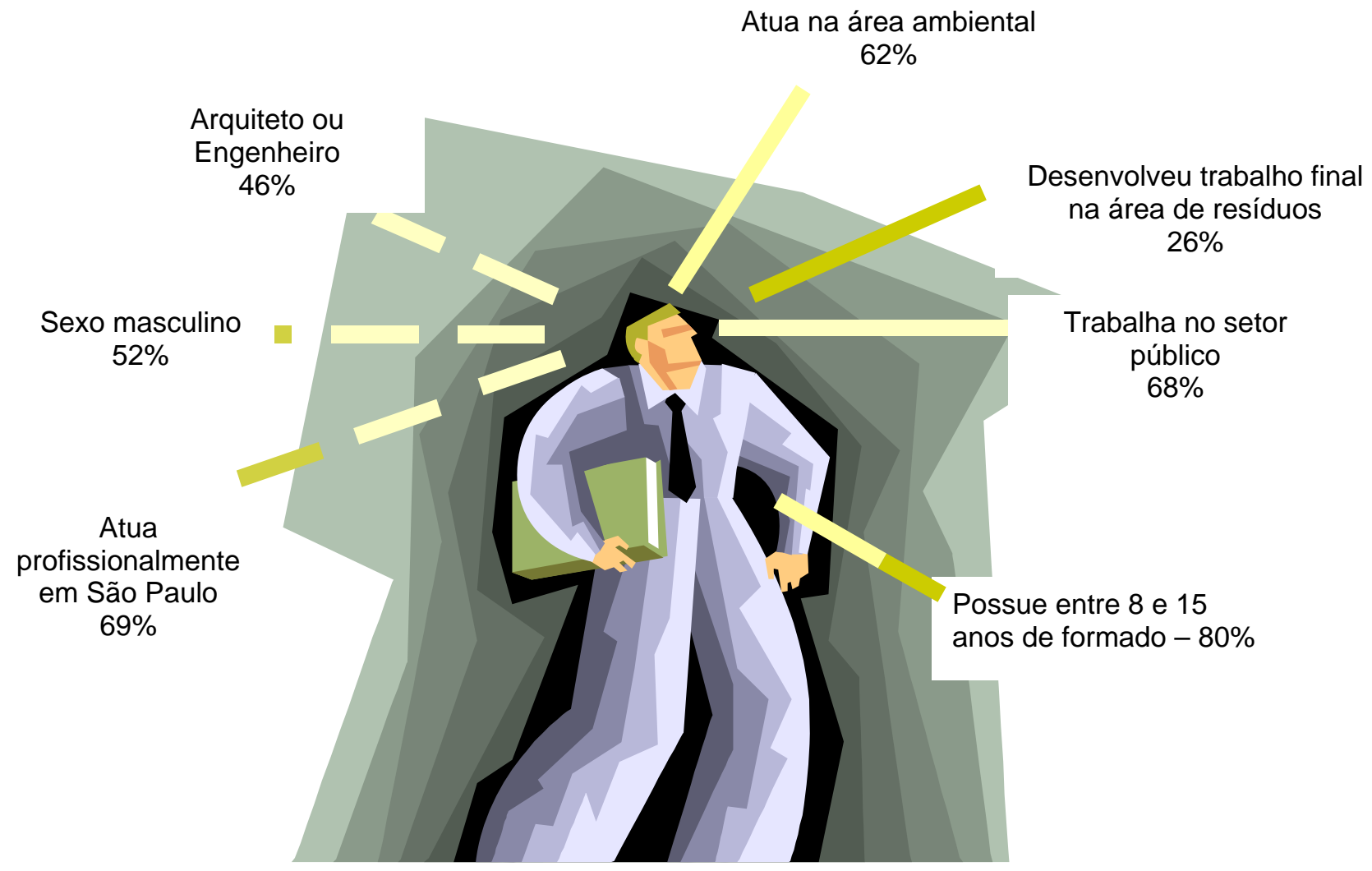

A presença de arquitetos e engenheiros com $46 \%$ foi devida à parceria da Faculdade de Saúde Pública com a Faculdade de Arquitetura e Urbanismo da Universidade de São Paulo. Esta parceria, divulgada explicitamente em propagandas e cartazes, foi uma fonte de atração para profissionais desta área, além certamente, do conteúdo do curso possuir especificidade na área ambiental, que atenda o interesse de ambos.

A presença do sexo feminino com $48 \%$ dos ex-alunos demonstra a participação e o papel cada vez maior da mulher no mercado de trabalho, buscando colocações mais elevadas e formas de capacitação que alavanque e consolide sua carreira. 
O tempo decorrido após a formação, entre 8 e 15 anos, demonstrou a procura pela reciclagem de conhecimentos e a obtenção de capacitação mais específica e profissionalizante, não oferecidos nos cursos originários de graduação. Considerando que os cursos CEGA exigem de seus alunos um esforço adicional bastante elevado pelo período de 1 ano, pois trabalham durante o dia, a procura elevada de profissionais com razoável tempo de formado por estes cursos, denota uma elevada concorrência existente no mercado de trabalho e conseqüentemente uma procura por profissionais cada vez mais capacitados nas diversas áreas de atuação que estes cursos oferecem.

Por outro lado, observa-se uma concentração de estudo no tema resíduo sólido, prova disto é decisão dos alunos em desenvolver seus trabalhos de final de curso nesta área, o que parece ser devido à preocupação com o impacto da produção de resíduos nos grandes centros urbanos de um lado; e de outro, o impacto crescente deste problema nas cidades de origem dos ex-alunos que são cidades de porte médio. Além disso, a falta de soluções eficazes para grande parte dos resíduos gerados nos setores industrial, comercial e residencial e a contaminação visível dos recursos naturais nos centros urbanos e nas áreas rurais são outros fatores de forte atração.

\subsection{Conclusões da $2^{\mathrm{a}}$. Etapa da pesquisa}

A aplicação do Roteiro de Entrevistas aos 143 ex-alunos respondentes resultou em um perfil bastante claro do impacto da capacitação em gestão ambiental para esta amostra representativa e para o universo dos 408 alunos dos 13 cursos analisados nesta tese.

\subsubsection{Atuação na área ambiental}

No início do curso cerca de $62 \%$ dos ex-alunos atuavam na área ambiental, percentual este que passou para $70 \%$ após a conclusão do curso, 
significando uma elevação de 8\% de profissionais trabalhando na área, que, ou mudaram para setores pertinentes dentro da própria empresa, ou houve mudança de empresa ou local de trabalho.

Figura 5.2 - Variação de atuação na área ambiental
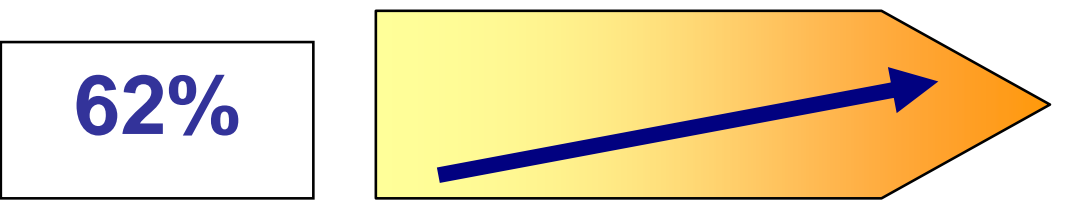

$70 \%$

\subsubsection{Setores de atuação}

No início do curso os ex-alunos atuavam nas seguintes proporções por setor: Público (68\%); Privado (30\%); ONG (2\%) e após a conclusão do curso, as proporções observadas indicaram uma diminuição da atuação no setor Público (62\%) um aumento no setor Privado (33\%) e um aumento na ONG (5\%).

Figura 5.3 - Variação de atuação por setor
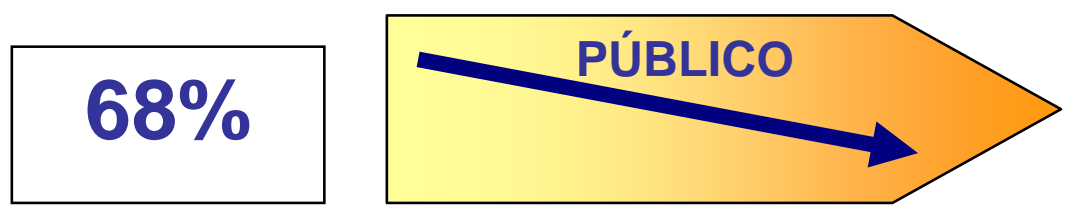

$62 \%$
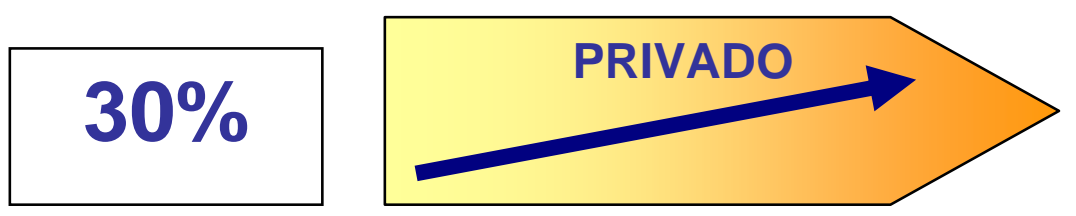

$33 \%$

$2 \%$

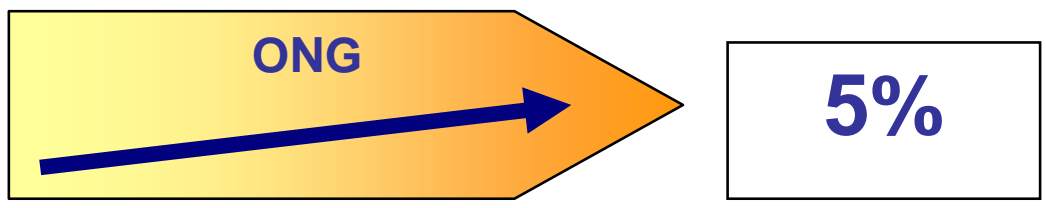




\subsubsection{Indicadores de impacto na atuação profissional}

Figura 5.4 - Variação de atuação por setor

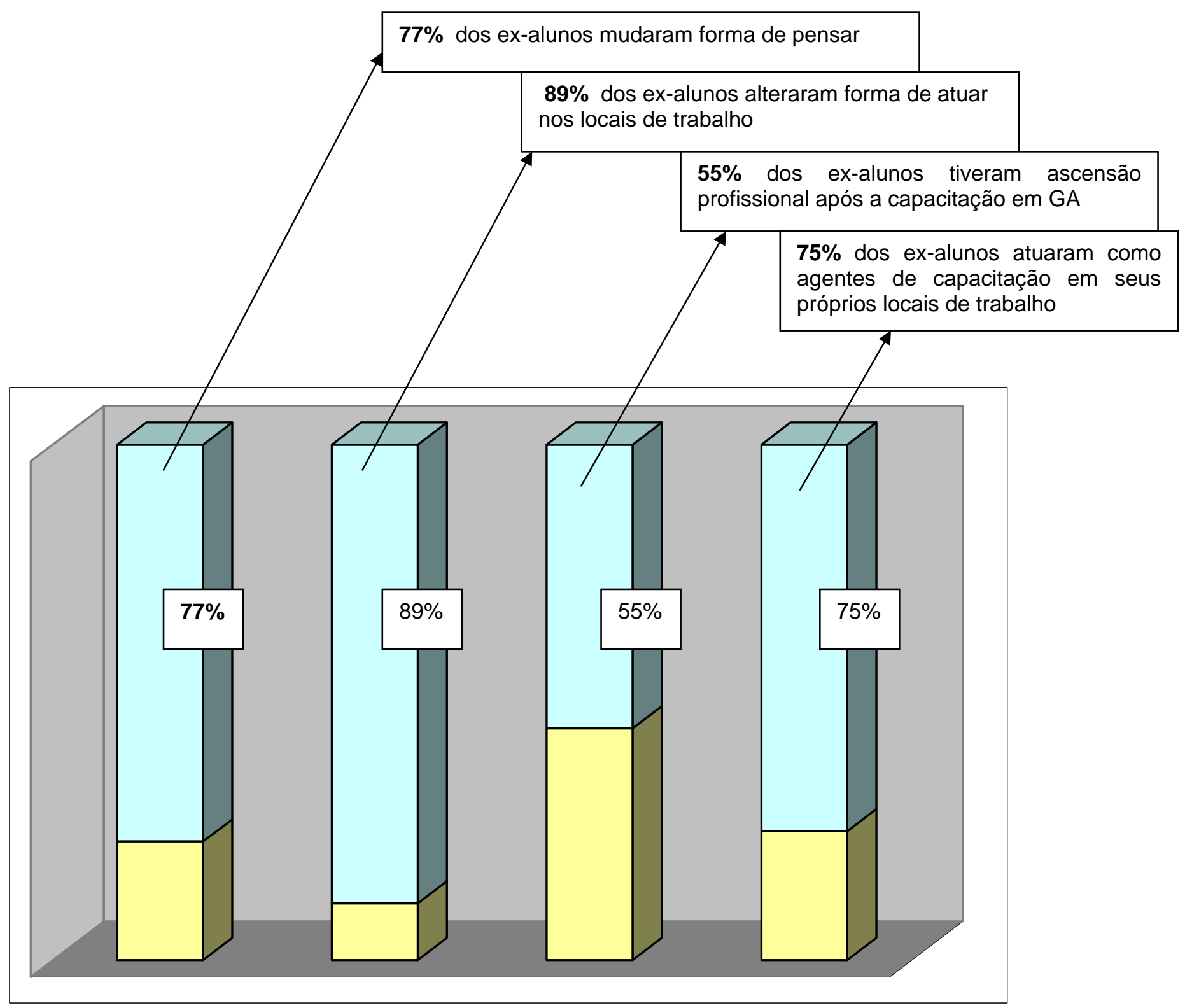


Além dos aspectos mencionados e indicados na figura 5.4 os ex-alunos relataram que o conhecimento obtido no curso de capacitação está sendo útil hoje nos locais em que trabalham (75\%).

No âmbito da atuação regional, analisada no capítulo 4, nota-se uma elevada dispersão dos alunos no Estado de São Paulo, ao mesmo tempo houve representação de outras regiões do país. Na $1^{\text {a }}$. Etapa da pesquisa foram mapeados os locais de atuação dos ex-alunos nas regiões do país. $\mathrm{Na} 2^{\mathrm{a}}$. Etapa da pesquisa reforçou-se a indagação de qual era o local de atuação do ex-aluno. Daqueles que participaram da amostra, apenas dois disseram ter alterado os seus locais de atuação profissional, um deles deslocando-se para São Lourenço e o segundo deslocando-se para Fortaleza (Figuras 5.5).

Figura 5.5 - Mapas de atuação regional.

\section{NO INÍCIO DO CURSO}

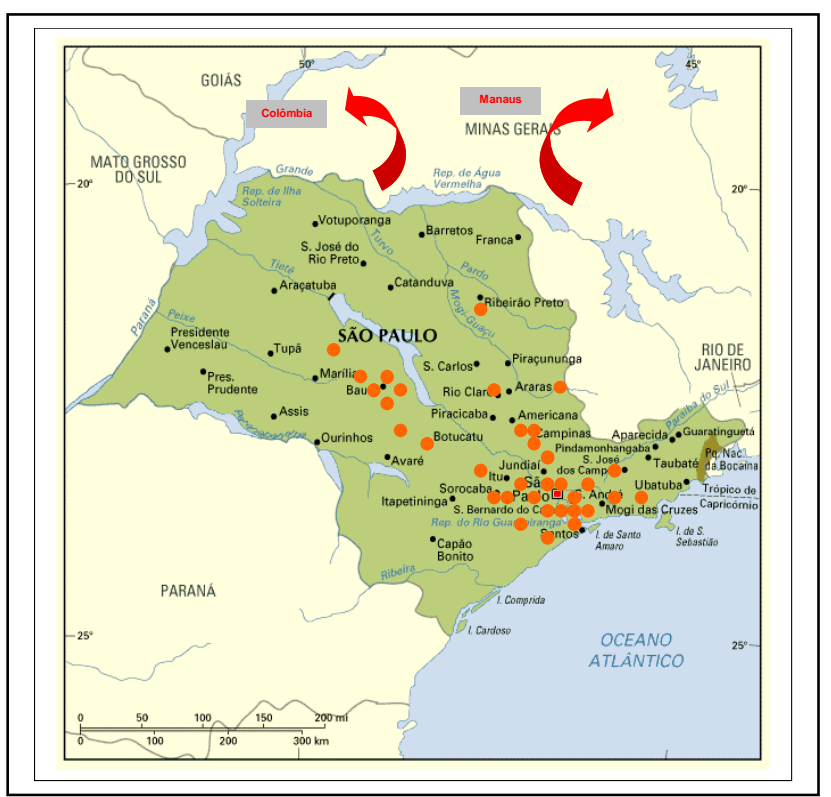

ATUALMENTE

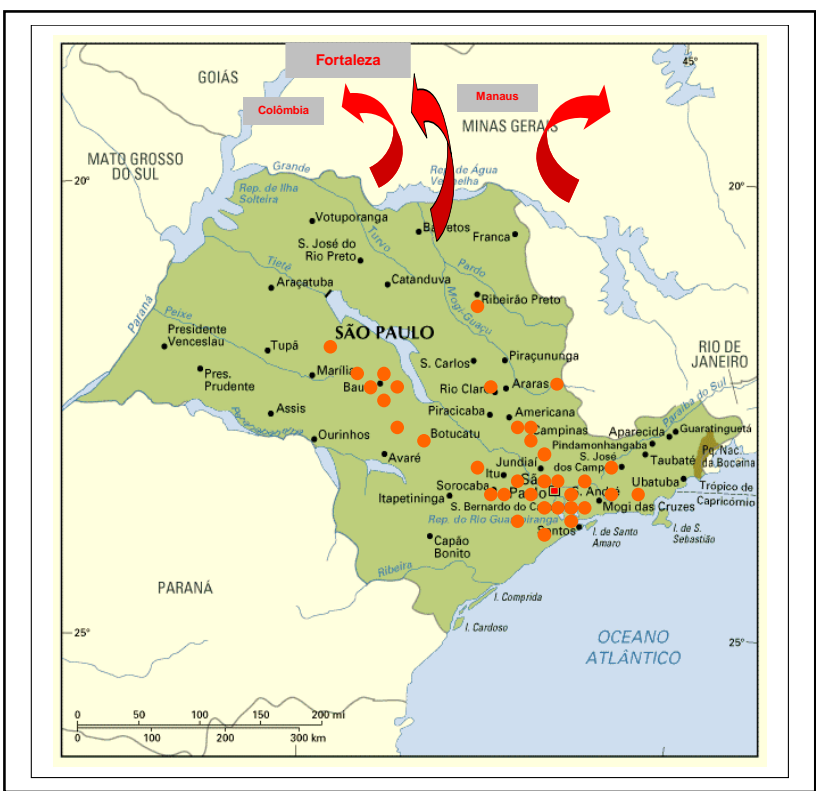


Além dos aspectos mencionados e apontados na Figura 5.4 as respostas dos ex-alunos indicaram que, atualmente, o conhecimento obtido nos cursos de capacitação CEGA, está sendo útil em seus locais de trabalho.

Em termos de avaliação quantitativa, a média apontada para este conhecimento utilizado, foi de 8,0 pontos em uma escala de 0 a 10.

Pode-se considerar que decorridos sete anos no máximo e dois anos no mínimo da conclusão dos cursos avaliados, os ex-alunos ao darem oito pontos na avaliação, estavam concordando que os conhecimentos adquiridos durante o curso mostravam-se ainda atuais e pertinentes, mesmo decorridos tempos diferentes de término de formação destes ex-alunos. Este foi um indicador interessante da sólida informação teórica recebida e avaliada como alta pelos alunos.

\subsection{Objetivos e hipóteses}

Tendo em vista a demonstração do aluno típico, por meio do levantamento detalhado em cada uma das 408 fichas de inscrição ( $1^{a}$. Etapa da pesquisa), considerando as variáveis listadas no início deste capítulo, pode-se dizer que foi cumprido o primeiro objetivo específico desta tese: caracterizar o perfil dos alunos dos cursos de gestão ambiental (CEGA).

Igualmente afirma-se que a partir do Roteiro de Entrevistas aplicado aos 143 ex-alunos respondentes ( $2^{\mathrm{a}}$. Etapa da pesquisa), os demais objetivos específicos desta tese foram cumpridos: (1) conhecer a opinião dos alunos com relação à sua atuação no mercado profissional, no momento atual, à luz da capacitação realizada na área de gestão ambiental; (2) avaliar as mudanças e os impactos ocorridos na vida profissional dos ex-alunos, após a capacitação realizada na área de gestão ambiental. 
Finalmente, pode observar que considerando as hipóteses iniciais, os profissionais capacitados nos Cursos de Especialização em Gestão Ambiental (CEGA), vêm suprindo parte da demanda por esta especialidade, em suas áreas de atuação regional. Mas ainda, estão atuando em no âmbito da problemática ambiental, e, conseqüentemente, vêm contribuindo para a supressão ou mitigação de problemas ambientais, em suas regiões de atuação. Isto é o que esta tese veio demonstrar. 


\section{CAPÍTULO 6 - CONSIDERAÇÕES FINAIS}

Ao se olhar o perfil do profissional que vem sendo gerado pelos cursos de capacitação em Gestão Ambiental, verifica-se que os mesmos vêm contemplando os objetivos pensados por ocasião de seu planejamento, ou seja, que existeisse um percentual de participação acima de 50\% de profissionais do setor público e um percentual equivalente direcionado para o setor privado, entendendo o setor privado como o conjunto das ONGs, das indústrias, das empresas de consultoria e projeto, e os indivíduos recémformados. Segundo este perfil, seria importante no futuro, continuar oferecendo cursos que mantenham esta proporção. No entanto, vale ressaltar que não é mais prática do setor público em geral, capacitar seus quadros, devido ao caráter imediatista de gestão de governo com ações de resultados a curto prazo.

Este fato reforça mais ainda a postura e o papel da Universidade, ao atuar junto às instituições do setor público, mostrando a importância da capacitação para suprir essas necessidades. Com relação aos profissionais do setor privado, esta tese demonstrou que se deve continuar oferecendo este tipo de capacitação-especialização para aqueles que desejam ampliar seus conhecimentos, incorporando a suas atividades uma postura de ação na área ambiental. A atual distribuição dos ex-alunos-profissionais, proporcionalmente aos setores de origem pública, privada ou recémformado, representou a proposta inicial quando das primeiras discussões, acerca da criação do CEGA, definindo mais uma vez, que este modelo deve continuar.

Quanto a conteúdo para um futuro próximo, imaginou-se a incorporação de disciplinas tais como, economia ambiental, gerando uma relação mais 
direcionada às questões econômicas associadas aos projetos ambientais; e como questões das realidades nacional e internacional, relacionadas à Gestão Ambiental, conforme ressaltado na Agenda 21 Brasileira lançada em julho de 2002.

Com relação à presença de economistas e administradores entre os exalunos, confirma-se o interesse destes profissionais pela área ambiental e reforça também o interesse da coordenação do Curso em acrescentar tais conteúdos.

A atuação dos ex-alunos em seus locais de trabalho e em suas ações regionais, permite que se procure redirecionar o projeto de capacitação, no conteúdo e disciplinas, tendo em vista o perfil e as especificidades dos alunos capacitados. Esta análise permitiu também conhecer mais profundamente os alunos que procuram os cursos, suas origens e seus potenciais para futuras atuações.

Esta tese contribui também para o desenvolvimento de uma metodologia de avaliação de curso que permite sua reprodutibilidade em outros projetos de capacitação. Contribui, ainda para o aperfeiçoamento dos demais cursos de especialização em andamento, tais como: Educação Ambiental, Direito Ambiental, Controle Ambiental e Engenharia de Saneamento Básico.

Esta tese demonstra assim que um conteúdo multidisciplinar na área de Gestão Ambiental, recebido por um grupo de profissionais, também de caráter multidisciplinar, cerca de 30 formações diferenciadas nas áreas de humanas, exatas e biológicas, produziu um impacto significativo na sociedade. 
O ato de avaliar e planejar o processo, revela-se sempre como desejável, porque inclui ações que geram mudanças e geram controles, e estes que geram novas mudanças. Portanto, após uma avaliação de caráter mais amplo como esta, conclui-se pela pertinência de continuar com projetos como este. A tendência verificada após a conclusão desta tese que analisa 13 cursos entre os 15 concluídos, entre março de 1995 e dezembro de 2001, é a criação de propor e implementar o mestrado profissionalizante na área de Gestão Ambiental.

A presente tese demonstrou que a Universidade vem cumprindo com sua missão de contribuir para a transformação da sociedade e acena positivamente para a necessidade de continuar a capacitação em gestão ambiental. 


\section{CAPÍTULO 7 - REFERÊNCIAS}

ACIESP. Glossário de termos usuais em ecologia. São Paulo, Secretaria de Indústria, Comércio, Ciência e Tecnologia, 1980. 150p. (Publicação ACIESP $n^{\circ} 24$ ).

Abreu AR, Laranjeira MI, Nogueira N, Solego R. Referências para a formação de professores. In: Bicudo MAV, Silva Jr CA. Formação do Educador e avaliação educacional: formação inicial e contínua. São Paulo: Editora UNESP; 1999. v.2.

Bannock G., et all. The penguin dictionary of economics. Middlesex, Penguin Books, 1977. p. 428

Braile PM, Dicionário inglês-portugues de poluição industrial. Rio de Janeiro, Serviço Social da Indústria, 1983. n.p.

Bruna GC. Meio ambiente urbano e proteção ambiental. In: Philippi JR.A, Alves AC, Roméro MA, Bruna GC, editores. Meio ambiente, direito e cidadania. São Paulo: USP/Signus Editora; 2002.

Campos C. São Paulo pela lente da higiene: as propostas de Geraldo Horácio de Paula Souza para a cidade. (1925-1945\}. São Carlos: Rima; 2002.

Candeias NMF. Memória histórica da Faculdade de Saúde Pública da Universidade de São Paulo. Revista de Saúde Pública, São Paulo, 18 (nº esp.): 2-60; 1984.

Carvalho B. de A. Glossário de saneamento e ecologia. Rio de Janeiro, Associação Brasileira de Engenharia Sanitária e Ambiental, 1981. 203 p.

Caffé Alves A. Saneamento básico: concessões permissões e convênios públicos. São Paulo: EPIDRO; 1998.

Coimbra JAA. O outro lado do meio ambiente. São Paulo: CETESB; 1985.

COPASAD. Conferência Pan-Americana sobre saúde e ambiente no desenvolvimento humano sustentável. Plano nacional de saúde e ambiente no desenvolvimento sustentável. Diretrizes para implantação. Brasília: Ministério da Saúde; 1995.

[CMMAD]. Comissão Mundial de Desenvolvimento e Meio Ambiente da América Latina e Caribe. Nossa própria agenda. New York: BID/PNUD; 1990.

[CMMAD]. Comissão Mundial sobre Meio Ambiente e Desenvolvimento. Nosso futuro comum. Rio de Janeiro: FGV; 1991 
Dajoz R. Ecologia geral. Trad. Francisco M. Guimarães. Petrópolis, Vozes e Universidade de São Paulo, 1973. 472p.

Dowbor L. Governabilidade e descentralização. Revista de Serviço Público. Brasília: ENAP, V.118, p. 95-118, jan./jul., 1994.

[FEEMA] Fundação Estadual de Engenharia do Meio Ambiente. Vocabulário básico do meio ambiente. $4^{\circ}$ Edição. Rio de Janeiro: Petrobras; 1992.

Freire P. Educação e mudança. São Paulo: Editora Paz e Terra, $7^{a}$ edição; 1983.

Freire $\mathrm{P}$. Pedagogia da autonomia - saberes necessários à prática educativa. São Paulo: Editora Paz e Terra; 11ª edição, 1999.

Furtado C. Brasil: a construção interrompida. São Paulo: Editora Paz e Terra; 1992.

Furtado C. Os ares do mundo. São Paulo: Editora Paz e Terra; 1991.

Gallopin G. El ambiente humano y planificación ambiental. Madrid. Centro Internacioanal de Formación en Ciencias del Ambiente, 1981. 30 p. (Opiniones, Fascículos de Medio Ambiente $\mathrm{n}^{\circ} 1$ )

Goodland R. Glossário de ecologia brasileira. Manaus, Imprensa Oficial do Estado, 1975. 96 p.

Interim Mekong Comitte. Environmental impact assessment guidelines of application to tropical niver basin development. Bangkok, Mekong Secretariat, 1982. $123 \mathrm{p}$.

Kidder LH, organizador. Métodos de pesquisa nas relações sociais - 1: delineamento da pesquisa. São Paulo: EPU; 1981.

Layrargues PP. Educação para a gestão ambiental: a cidadania no enfrentamento político dos conflitos sócio ambientais. In: Loureiro CFB (Org.). Sociedade e meio ambiente: a educação ambiental em debate. São Paulo: Cortez; 2000.

Lima e Silva PP, Guerra AJT, Mousinho P, Bueno C, Almeida FG, Malheiros T, Souza Jr AB. Dicionário Brasileiro de Ciências Ambientais. Rio de Janeiro: Thex Editora; 1999.

[MMA/PNUD] Ministério do Meio Ambiente. Programa das Nações Unidas para o Desenvolvimento. Agenda 21 brasileira: bases para discussão. Brasília; 2000a. 
[MMA-IBAMA] Ministério do Meio Ambiente, Instituto Brasileiro do Meio Ambiente e dos Recursos Naturais Renováveis. Agricultura sustentável. Brasília: 2000b.

[MMA-IBAMA] Ministério do Meio Ambiente, Instituto Brasileiro do Meio Ambiente e dos Recursos Naturais Renováveis. Infra estrutura e integração regional. Brasília: 2000c.

[MMA-IBAMA] Ministério do Meio Ambiente, Instituto Brasileiro do Meio Ambiente e dos Recursos Naturais Renováveis. Ciência e tecnologia para desenvolvimento sustentável. Brasília: $2000 d$.

[MMA-IBAMA] Ministério do Meio Ambiente, Instituto Brasileiro do Meio Ambiente e dos Recursos Naturais Renováveis. Para a gestão dos recursos naturais. Brasília: 2000e.

[MMA-IBAMA] Ministério do Meio Ambiente, Instituto Brasileiro do Meio Ambiente e dos Recursos Naturais Renováveis. Redução da desigualdade. Brasília: 2000f.

[MMA-IBAMA] Ministério do Meio Ambiente, Instituto Brasileiro do Meio Ambiente e dos Recursos Naturais Renováveis. Cidades sustentáveis. Brasília: 2000g.

Marques MO. A formação do profissional da educação. ljuí, RS: Editora Unijuí; 1992. p 222.

Masseto R. Pós graduação: rastreando o caminho percorrido. In: Serbiano RV, Ribeiro R, Barbosa RLL, Sebran RA, (Org.). Formação de professores (Seminários Debates UNESP). São Paulo: Editora UNESP; 1998. p 357

Mattar FN. Pesquisa de marketing 1 - metodologia e planejamento. São Paulo: Atlas; 2000.

Milaré E. Direito do Ambiente: doutrina, prática, jurisprudência, glossário. São Paulo: Editora Revista dos Tribuanais; 2000.

Minayo MCS. Globalização, desenvolvimento sustentável e meio ambiente. In: Ciência \& saúde coletiva. ABRASCO, Fundação Oswaldo Cruz, vol 3, $\mathrm{n}^{\circ}$ 1, Rio de Janeiro; 1998.

Moog V. Bandeirantes e Pioneiros. Paralelo entre duas culturas. Porto Alegre: Editora Globo; 11ª edição; 1974.

Moreira IVD. Vocabulário básico de meio ambiente. Rio de Janeiro: FEEMA; 1990. 
Munn RE. Enviromental impact assessment. Toronto, John Wiley \& Sons, 1979 p. Theory and application of modelling in EIA. In: Enviromental impact assessment. The Haghe, Martinus Nijhff, 1983. pp 281. 281-91.(NATO/ASI séries D Behaviour and Social Sciences $n^{\circ} 14$ )

Odum EP. Ecologia. $3^{\circ}$ Edição. Trad. Carlos Ottenwaelder. México D.F., Interamérica, 1972. 639 p.

Ornstein SW, Bruna GC, Roméro MA. Ambiente construído e comportamento: a avaliação pós-ocupação e a qualidade ambiental. São Paulo: Estúdio Nobel, FAU/FUPAM; 1995.

Ornstein S, Roméro M. (colaborador) Avaliação pós-ocupação do ambiente construído. São Paulo: Editora da Universidade de São Paulo; 1992.

Pelicioni MCF, Philippi Jr. A, Meio ambiente, direito e cidadania: uma interação necessária. In: Philippi Jr. A, Caffé Alves A, Roméro MA, Bruna GC, editores. Meio ambiente direito e cidadania. São Paulo: USP/Signus Editora; 2002.

Pelicioni MCF. Educação em saúde e educação ambiental - estratégias de construção da Escola Promotora da Saúde. São Paulo; 2000. [Tese de livre Docência da Faculdade de Saúde Pública da Universidade de São Paulo]

Philippi Jr. A, Tucci CEM, Hogan DJ, Navegantes. Interdisciplinaridade em Ciências Ambientais. São Paulo: Editora Signus; 1999.

Rio' 92. Conferência das Nações Unidas sobre meio ambiente e desenvolvimento. Agenda 21. Brasília: Diário Oficial da União; 1994. [Tradução do Ministério das Relações Exteriores. DOU 02/08/94].

Sachs I. Estratégias de transição para o século XXI. In: Sachs I. Para pensar o desenvolvimento sustentável. Brasília: IBAMA/ENAP, Brasiliense; 1993.

Sahop. Secretaría de Asentamientos Humanos y Obras Públicas. Glosario de términos sobre asentamientos humanos. México. D.O., Sahop, 1978. $175 \mathrm{p}$.

Santos B. Pelas mãos de Alice. O social e o político na pós modernidade. São Paulo: Cortez; 1999.

Souza CP. Avaliação da aprendizagem formadora. Avaliação formadora da aprendizagem. In: Bicudo MAV, Silva Jr CA. Formação do educador e avaliação educacional: avaliação institucional, ensino e aprendizagem. São Paulo: Editora UNESP; 1999. (Seminários e Debates) V.4. 
Steinberger M, Bruna GC. Cidades médias: elos do urbano regional e do público privado. In: Thompson AA, Serra RV (organizadores). Cidades médias brasileiras. São Paulo: IPEA; 2001. 


\section{BIBLIOGRAFIA COMPLEMENTAR}




\section{BIBLIOGRAFIA COMPLEMENTAR}

[IBAMA] Instituto Brasileiro do Meio Ambiente e dos Recursos Naturais Renováveis. Redução das desigualdades sociais. In: Bezerra MCL, et al, coordenadores. Subsídios à elaboração da agenda 21 brasileira Brasília (DF): Ministério do Meio Ambiente IBAMA; 2000.

[IBAMA] Instituto Brasileiro do Meio Ambiente e dos Recursos Naturais Renováveis. Gestão dos recursos naturais. In: Bezerra $\mathrm{MCL}$ et al, coordenadores.Subsídios à elaboração da Agenda 21 brasileira. Brasília (DF): Ministério do Meio Ambiente; 2000.

[IBAMA] Instituto Brasileiro do Meio Ambiente e dos Recursos Naturais Renováveis. Cidades Sustentáveis. In: Bezerra MCL et al, coordenadores. Subsídios à elaboração da Agenda 21 brasileira. Brasília; 2000a.

Aguiar A, Philippi Jr. A. Reciclagem de plástico de resíduos sólidos domésticos: problemas e soluções. In: $8^{\circ}$ Simpósio Luso-Brasileiro de Engenharia Sanitária e Ambiental; 1998; João Pessoa (BR). João Pessoa: ABES; 1998. p.610-29.

Aguiar A, Philippi Jr. A. A importância das parcerias no gerenciamento de resíduos sólidos domésticos. In: Anais do $20^{\circ}$ Congresso Brasileiro de Engenharia Sanitária e Ambiental; 1999 Maio 10-14; Rio de Janeiro (BR). Rio de Janeiro: ABES; 1999. p.1910-9.

Aguiar A, Philippi Jr. A. Custos da coleta seletiva: critérios de apuração e viabilidade dos programas. In: Trabalhos Técnicos do $27^{\circ}$ Congresso Interamericano de Engenharia Sanitária e Ambiental; 2000. Dez 3-8; Porto Alegre, (BR). Porto Alegre: ABES; 2000a. p.183.

Aguiar A, Philippi Jr. A. O papel das parcerias na operação de programas de coleta seletiva. In: SILUBESA - Simpósio Luso Brasileiro de Engenharia Sanitária e Ambiental; [CD-ROM]; 2000 Abr 9-14; Porto Seguro (BR). Porto Seguro: ABES; 2000b.

Almeida JR, Mello CS, Cavalcanti Y. Gestão ambiental: planejamento, avaliação, implantação e verificação. Rio de Janeiro: Thex; 2000.

Bressan Jr A, Philippi Jr. A, Andreoli CV, Silva MFB, Farias GL, Kravchychyn $M$. Diagnóstico institucional dos órgãos estaduais de meio ambiente no Brasil. Vitória: ABEMA; 1993. p.86.

Bruna GC, Philippi Jr. A. Gestão urbana ambiental e a cidadania. In: $27^{\circ}$ Congresso Interamericano de Engenharia Sanitária e Ambiental; 2000, Dez 3-8; [CD-ROM]; Porto Alegre (BR). Porto Alegre: ABES; 2000. 
Cascino F. Educação ambiental: princípios, história e formação de professores. São Paulo: SENAC; 1999.

Castro ML, Geiser SRA, Philippi Jr. A, Ogera RC, Salles CP. Conselho municipal de meio ambiente na formulação de políticas públicas. In: Anais do $26^{\circ}$ Congresso Interamericano de Engenharia Sanitária e Ambiental; 1998 Nov 1-5; Lima (Peru). Lima: DM; 1998.

Castro ML, Geiser SRA, Ogera RC, Salles CP, Philippi Jr. A. Conselho municipal de meio ambiente na formulação de políticas públicas. In: Philippi Jr. A et al, editores. Municípios e meio ambiente: perspectivas para a municipalização da gestão ambiental no Brasil. São Paulo: ANAMMA; 1999. p.109.

Cavalcanti C, organizador. Meio ambiente, desenvolvimento sustentável e políticas públicas. $2^{\mathrm{a}}$ ed. São Paulo: Cortez; 1999.

Coimbra JAA. O outro lado do meio ambiente. São Paulo: CETESB; 1985.

Community Design and Development Center. Available from: $<$ URL:http:www.cddcinc.org > [2002 Jul 5]

Crespo C. Educacion ambiental en America Latina. Quito: Instituto de Investigaciones Socio economicas y Tecnologicas; 1989.

DHCD. Revitalizing our neighbourhoods. [monogrph online] 2001 Available from: <URL:http:www.anca.state.ma.us> [2002, Jul 21]

Dias GF. Educação ambiental: princípios e práticas. São Paulo: Gaia; 1992.

Ferreira FC. A questão ambiental, sustentabilidade e políticas públicas no Brasil. São Paulo: Jinkings; 1998.

Ferreira LC, Viola E, organizadores. Incertezas da sustentabilidade na globalização. Campinas: UNICAMP; 1996.

Fundação Estadual de Engenharia do Meio Ambiente do Rio de Janeiro. Vocabulário básico de meio ambiente. Rio de Janeiro: Petrobras; 1992.

Grisotto LEG, Souza PRI, Leite CRS, Philippi Jr. A. Compreensão do sistema de gerenciamento de recursos hídricos através de ferramentas gerenciais da qualidade: o caso da bacia hidrográfica do alto Tietê - região metropolitana de São Paulo. In: Trabalhos Técnicos do $27^{\circ}$ Congresso Interamericano de Engenharia Sanitária e Ambiental; 2000 Dez 3-8; Porto Alegre (BR). Porto Alegre; 2000a. p.254. 
Grisotto LEG, Souza PRI, Leite CRS, Philippi Jr. A. Estudo de caso da aplicação da ferramenta CPOQ na análise do sistema de gerenciamento dos recursos hídricos da bacia hidrográfica do alto Tietê. In: Trabalhos Técnicos do $27^{\circ}$ Congresso Interamericano de Engenharia Sanitária e Ambiental; 2000 Dez 3-8; Porto Alegre (BR). Porto Alegre; 2000b. p.255.

Hogan DJ, organizadores. Migração e ambiente em São Paulo: aspectos relevantes da dinâmica recente. Campinas: Núcleo de Estudos de População/UNICAMP; 2000a.

Hogan DJ, Philippi Jr. A. A importância de núcleos interdisciplinares em ensino, pesquisa e extensão. In: Philippi Jr. A et al, editores. Interdisciplinaridade em ciências ambientais. São Paulo: Signus; 2000b. p.246.

Jacobi PR, oganizador. Ciência ambiental, os desafios da interdisciplinaridade. São Paulo: Annablume; 1999.

Kidder $\mathrm{L} H$, organizador. Métodos de pesquisa nas relações sociais - 2: medidas na pesquisa social. São Paulo: EPU; 1981a.

Kidder $\mathrm{L} H$, organizador. Métodos de pesquisa nas relações sociais - 3 : análise de resultados. São Paulo: EPU; 1981b.

Kidder $\mathrm{L} H$, organizador. Métodos de pesquisa nas relações sociais - 1: delineamento da pesquisa. São Paulo: EPU; 1981c.

Kotler P, Armstrong G. Princípios de marketing. Rio de Janeiro: LTC; 1998.

Lamonier B., Figueredo R. As cidades que dão certo: experiências inovadoras na administração pública brasileira. Brasília: $\mathrm{MH}$ Comunicação; 1996.

Leff E. Complexidade, interdisciplinaridade e saber ambiental. In: Phillippi Jr A et al, editores. Interdisciplinaridade em ciências ambientais. São Paulo: Signus; 2000. p.19-51.

Leonard JL, organizador. Meio ambiente a pobreza: estratégias de desenvolvimento para uma agenda comum. Trad. de Jungmann R. Rio de Janeiro; 1992.

São Paulo. Estado. São Paulo'92: perfil ambiental e estratégias. São Paulo: Secretaria do Meio Ambiente, CETESB, 1992. p.181.

Maglio IC, Philippi Jr. A. Gestão ambiental nas empresas de saneamento. In: Anais do $9^{\circ}$ SILUBESA - Simpósio Luso Brasileiro de 
Engenharia Sanitária e Ambiental; 2000 Abr 9-14; Porto Seguro (BR). Rio de Janeiro: ABES, 2000.

Marcon G, Philippi Jr. A. Águas transfronteiriças à luz do direito internacional do meio ambiente. In: Anais do $4^{\circ}$ Inter-American Dialogue On Water Management in Quest of Solution; 2001 Sept 2-6; Foz do Iguaçu (PR).

Mattar, F N. Pesquisa de marketing 1 - metodologia e planejamento. São Paulo: Atlas; 2000. p.335.

Ministério do Meio Ambiente. PNUD - Programa das Nações Unidas para o Desenvolvimento. Agenda 21 brasileira: bases para discussão. Brasília; $2000 b$.

Nalini JR. Ética ambiental. Campinas: Millennium; 2001.

Nicolescu B. O manifesto da transdisciplinaridade. São Paulo: Triom; 1999.

Nicolescu B, Pineau G, Maturana H, Random M, Taylor P. Educação e transdisciplinaridade. Brasília: UNESCO; 2000.

Ogera RC, Kudzielicz E, Philippi Jr. A, Redolfi SCS. Planejamento estrategico para a gestão ambiental de municípios: a experiência de São Paulo. In: Anais do $20^{\circ}$ Congresso Brasileiro de Engenharia Sanitária e Ambiental; 1999 Maio 10-14; Rio de Janeiro (BR). Rio de Janeiro: ABES; 1999. p. 208-9.

Paiva AG, Philippi Jr. A. Gestão de recursos hídricos: uma análise do plano de bacias hidrográficas dos rios Piracicaba, Capivari e Jundiaí entre 19941995. In: Trabalhos Técnicos do $27^{\circ}$ Congresso Interamericano de Engenharia Sanitária e Ambiental; 2000 Dez 3-8; Porto Alegre (BR). Porto Alegre; 2000. p.253.

Pedroso MFM, Philippi Jr. A. Disposição de resíduos de laboratório-estudo de caso. In: 5 Encontro Brasileiro de Ecotoxicologia; 1988 17-18; Itajaí (SC).

Pedroso MFM, Philippi Jr. A. Disposição de resíduos de laboratório: estudo de caso. In: Anais do $20^{\circ}$ Congresso Brasileiro de Engenharia Sanitária e Ambiental; 1999 Maio 10-14; Rio de Janeiro (BR). Rio de Janeiro: ABES; 1999. p.3877-85.

Pelicioni MCF, Philippi Jr. A. Educação ambiental e desenvolvimento sustentável: material instrucional. In: Anais do $20^{\circ}$ Congresso Brasileiro 
de Engenharia Sanitária e Ambiental; 1999 Maio 10-14; Rio de Janeiro (BR). Rio de Janeiro; 1999. 2540-48.

Pelicioni MCF. Educação em saúde e educação ambiental. estratégias de construção da escola promotora da saúde. São Paulo; 2000. [Tese de Livre-Docência - Faculdade de Saúde Pública da USP]

Philippi Jr. A et al. Saneamento do meio. São Paulo: Fundacentro; 1988d. p. 235.

Philippi Jr. A, Brunacci A, Andreoli CV, Moreira IVD. Brazil'92: environmental profile and strategies. São Paulo: Gráfica do Estado; 1992a. p.51

São Paulo. Estado. Região sudeste 92: perfil ambiental e estratégias. São Paulo: Governo do Estado de São Paulo/Secretaria do Meio Ambiente/CETESB; 1992c. p.108.

Philippi Jr. A, Elias EO. A questão ambiental urbana: cidade de São Paulo. São Paulo: Gráfica Municipal; 1993. p.765.

Philippi Jr. A, Prandini FL, Elias EO, Nakazawa V, Antunes EA, Ogera RC. Urban environmental management: strengthening capabilities at local level. the city of São Paulo. In: International Symposium, Urban Environmental Management: Strengthening Capabilities at Local Level; 1995 Jun 2830; São Paulo (BR); 1995c.

Philippi Jr. A. Coord. Agenda 21 local: compromisso do município de São Paulo: São Paulo: Secretaria Municipal do Verde e do Meio Ambiente; 1996a. p.165.

Philippi Jr. A, Ribeiro MA, Brito MCW. Ações voltadas para implementação regional da agenda 21. In: Rio-92 cinco anos depois; Rio de Janeiro: Alphagrafics; 1997a. p. 229-51.

Philippi Jr. A, Pelicioni MCF. Formação de recursos humanos em gestão e educação ambiental. In: 19 $^{\circ}$ Congresso Brasileiro de Engenharia Sanitária e Ambiental; 1997, Set 14-19; Foz do Iguaçu (BR); 1997. p.272.

Philippi Jr. A, Pelicioni MCF, Barros RLF, Brandt Filho W, Tristão VTV. Agenda 21 local como instrumento de controle e gestão ambiental. In: Anais do $26^{\circ}$ Congresso Interamericano de Engenharia Sanitária e Ambiental; 1998; [CD-ROM]; Lima (Peru). Lima: ADM; 1998b.

Philippi Jr. A, Pelicioni MCF, Tristão VTV. Agenda 21 e os assentamentos sustentáveis. In: Habitat Brasil'98, 1998d; Florianopólis (BR); [Sessão Poster]. 
Philippi Jr. A, Pelicioni MCF. Capacitação de profissionais na área ambiental para o setor público. Debates Soc Amb, 1998e; 3(10):25-6.

Philippi Jr. A, Bruna GC. Enverdecimiento urbano en Brasil: um estudio de caso. In: Krishnamurthy $\mathrm{L}$ et al, editores. Áreas verdes Urbanas en Latinoamérica y el Caribe. Chapingo (DR): Univerdidad Autónoma Chapingo; 1998f. p.197

Philippi Jr. A, Pelicioni MCF. A interdisciplinaridade como base da educação ambiental. In: $6^{\circ}$ Congresso Paulista de Saúde Pública; 1999; Águas de Lindóia (BR). São Paulo: APSP; 1999a. p.94.

Philippi Jr. A. Agenda 21 e resíduos sólidos. In: RESID'99: Seminário sobre Resíduos Sólidos; 1999 Set; 15-25; São Paulo (BR) São Paulo: ABGE; 1999b. p.15-25.

Philippi Jr. A, Pelicioni MCF. Agenda 21 Local: instrumento de controle social. In: Jornal da USP, São Paulo, 1999 Mar 08; 1999c. cad 3:3.

Philippi Jr. A, Zulauf WE. Estruturação dos municípios para a criação e implementação do sistema de gestão ambiental. In: Philippi Jr. A, Maglio IC, Coimbra JAA, Franco RM. Municípios e meio ambiente - perspectivas para a municipalização da gestão ambiental no Brasil; São Paulo: ANAMMA; 1999f. p.47-55.

Philippi Jr. A, Salles CP. Fortalecimento ambiental municipal: necessidades e perspectivas. In: Trabalhos Técnicos do $20^{\circ}$ Congresso Brasileiro de Engenharia Sanitária e Ambiental; 1999 Maio 10-14; Rio de Janeiro (BR). Rio de Janeiro: ABES. 1999g. p.2549-51.

Philippi Jr. A, Aguiar A, Moller BR. Gestão ambiental: a empresa e a sustentabilidade do seu desenvolvimento. In: Anais do $5^{\circ}$ Encontro Nacional de Gestão Empresarial e Meio Ambiente; 1999 Nov 17-19; São Paulo (BR); São Paulo: EAESP-FGV/FEA-USP; 1999 h.

Philippi Jr. A, Maglio IC, Coimbra JAA, Franco RM. Municípios e meio ambiente: perspectivas para a municipalização da gestão ambiental. São Paulo: ANAMMA; 1999k. p.201.

Philippi Jr. A, Maglio IC. A descentralização da gestão ambiental no Brasil: o papel dos órgãos estaduais e as relações com o poder local -1990-1999. In: $21^{\circ}$ Congresso Brasileiro de Engenharia Sanitária e Ambiental; 2001 Set 16-21; João Pessoa (BR); Rio de Janeiro: ABES; 2001a. p.326-7

Philippi Jr. A, Brito IRC, Coelho SC, Cesarini CJ, Pelicioni MCF. Cidades saudáveis: percepção e qualidade de vida no meio ambiente construído. In: 9 SILUBESA - Simpósio Luso Brasileiro de Engenharia Sanitária e 
Ambiental; 2000 Abr 9-14; Porto Seguro (BA). Rio de Janeiro: ABES; 2000b. p.1933.

Philippi Jr. A, Pelicioni MCF, Coimbra JAA. Educação ambiental: do passado e do presente para alcançar a sustentabilidade. In: Philippi Jr. A, Pelicioni MCF. Educação ambiental: desenvolvimento de cursos e projetos. São Paulo: Signus; 2000c. p.321.

Philippi Jr A, Bruna GC, Romero MA. Nas trilhas do meio ambiente: enfrentando desafios. In: Philippi Jr. A, Alves AC, Roméro MA, Bruna GC, editores. Meio ambiente, direito e cidadania. São Paulo: Signus; 2002e.p.3-7.

Philippi Jr. A, Alves AC, Roméro MA, Bruna GC. Meio ambiente, direito e cidadania. São Paulo: Signus; 2002f. p.358.

Philippi Jr. A, Marcon G. Subisídios do direito internacional ambiental ao gerenciamento de recursos naturais. In: $\mathbf{2 1}^{\circ}$ Congresso Brasileiro de Engenharia Sanitária e Ambiental; 2001 Set 16-21; João Pessoa (BR). Rio de Janeiro: ABES; 2001j. p.262.

Philippi Jr. A, Malheiros TF. Uma visão crítica da prática interdisciplinar. In: Philippi Jr. A, Tucci CEM, Hogan DJ, Navegantes R. Interdisciplinaridade em ciências ambientais. São Paulo: Signus; 2000l. p.147.

Philippi Jr. A, Rodrigues JER, Salles CP. Agenda 21: algumas experiências internacionais como subsídio para o caso brasileiro. In: $2^{\circ}$ Congresso Brasileiro de Engenharia Sanitária e Ambiental; 2001 Set 16-21; João Pessoa (BR). João Pessoa: ABES; 2001a. p.330.

Philippi Jr. A, Roméro MA. Capacitação profissional na área de gestão ambiental e sua interdisciplinariedade. In: $21^{\circ}$ Congresso Brasileiro de Engenharia Sanitária e Ambiental; 2001 Set 16-21; João Pessoa (BR). João Pessoa: ABES; 2001b. p.328.

Philippi Jr. A. Educação e capacitação ambiental. Rev. Direitos Difusos; 2001c; 1:709-10.

Platão. A república. $4^{a}$ ed. Lisboa: Fundação Calouste Gulbenkian; 1983. p.21-3.

Pratt Institute Center for Community and Environmental Development. Available from: <URL:http:www.picced.org> [2002 Jul 16]

Reigota M. A floresta e a escola: por uma educação ambiental pósmoderna. São Paulo: Cortez; 1999. 
Thompson P. A voz do passado. Rio de Janeiro: Paz e Terra; 1992.

Tsukada MGB, Lopez MCS, Philippi Jr. A. Uma contribuição institucional à prática da interdisciplinaridade. In: Philippi Jr. A, Tucci CEM, Hogan DJ, Navegantes R. Interdisciplinaridade em ciências ambientais; São Paulo: Signus; 2000. p.310.

Viana $G$, Silva M, Diniz N, organizadores. O desafio da sustentabilidade: um debate socioambiental no Brasil. São Paulo: Fundação Perseu Abramo; 2001.

Willums JO, Goluke U. From ideas to action: business and sustainable development. Norway: ICC; 1992.

Zulauf WE. Brasil ambiental: síndromes e potencialidades. São Paulo: Fundação Konrad Adenauer Stifung; 1993a.

Zulauf WE, Philippi Jr. A. Local Agenda 21: São Paulo's

Commitment. In: 11 th World Clean and Environment Congress; 1998 Sept 13-18; Durban, (South África). 1998b. p.1-5. 
GLOSSÁRIO 


\section{GLOSSÁRIO}

ABIÓTICO - Caracterizado pela ausência de vida. "Lugar ou processo sem seres vivos" (Goodland 1975). "Substâncias abióticas são compostos inorgânicos e orgânicos básicos, como água, bióxido de carbono, oxigênio, cálcio, nitrogênio e sais de fósforo, aminoácidos e ácidos húmicos etc. O ecossistema inclui tanto os organismos (comunidade biótica) como um ambiente abiótico" (Odum 1972).

AMBIENTALISTA - "Termo criado para traduzir environmentalist, surgido na última década para nomear a pessoa interessada ou preocupada com os problemas ambientais e a qualidade do meio ambiente ou engajada em movimentos de defesa do meio ambiente. Também usado para designar o especialista em ecologia humana" (FEEMA 1992).

ANÁLISE DE CUSTO-BENEFÍ́CIO - "Técnica que tenta destacar e avaliar os custos sociais e os benefícios sociais de projetos de investimento, para auxiliar ou decidir se os projetos devem ou não ser realizados... O objetivo é identificar e medir as perdas e ganhos em valores econômicos que arcará a sociedade como um todo, se o projeto em questão for realizado..." (Bannock 1977).

BACIA HIDROGRÁFICA - "Conjunto de terras drenadas por um rio principal e seus afluentes. Longitudinalmente, nas depressões ocorre a concentração das águas drenadas, formando um lençol fluente, os rios. Em toda bacia hidrográfica deve existir uma hierarquização da rede de drenagem, partindo dos pontos mais elevados para os mais baixos e de acordo com o dinamismo dos diferentes tributários" (Lima e Silva et al 1999).

BIOMA - A unidade biótica de maior extensão geográfica, compreendendo várias comunidades em diferentes estágios de 
evolução, porém denominada de acordo com o tipo de vegetação dominante: mata tropical, campo etc. "É uma unidade de comunidade biótica, facilmente identificável, produzida pela atuação recíproca dos climas regionais com a biota e o substrato, na qual a forma de vida da vegetação climática clímax é uniforme. O bioma inclui não somente a vegetação climática clímax, como também o clímax edáfico e as etapas de desenvolvimento, os quais estão dominados, em muitos casos, por outras formas de vida"(Odum 1972). "É um grupamento de fisionomia homogênea e independente da composição florística. Estende-se por um área bastante grande e sua existência é controlada pelo macroclima. Na comunidade terrestre, os biomas correspondem às principais formações vegetais naturais" (Dajoz 1973).

BIOTA - "Todas as espécies de plantas e animais existentes dentro de uma determinada área" (Braile, 1983). "Conjunto dos componentes vivos (bióticos) de um ecossistema" (Moreira 1990).

CAPITAL - "O estoque de bens que são usados na produção e que foram, eles mesmos, produzidos... Além disso, a palavra capital, em economia, geralmente significa "capital real" - isto é, bens físicos. $\mathrm{Na}$ linguagem de todo o dia, entretanto, capital pode ser usado para significar capital monetário (dinheiro), isto é, estoques de dinheiro que resultam de poupanças passadas. Há dois importantes aspectos do capital: (a) que sua criação implica um sacrifício, uma vez que se aplicam recursos para produzir bens de capital imobilizados (não consumíveis) em vez de bens de consumo imediato; (b) que se aumenta a produtividade dos outros fatores de produção, terrenos e trabalho, e é essa produtividade aumentada que representa a 
recompensa pelo sacrifício envolvido na criação do capital. Portanto, pode-se dizer que se cria capital apenas enquanto sua produtividade é ao menos suficiente para compensar o sacrifício para sua criação" (Bannock 1977).

CENÁRIO - "Modelo científico que permite ao pesquisador considerar elementos de um sistema social como se realmente funcionassem da maneira descrita. Os cenários não testam as hipóteses. Antes permitem o exame dos possíveis resultados, caso as hipóteses fossem verdadeiras" (Erikson 1975 apud Munn 1983).

CIDADE - Centro populacional permanente, altamente organizado, com funções urbanas e políticas próprias. "Espaço geográfico transformado pelo homem através da realização de um conjunto de construções com caráter de continuidade e contigüidade. Espaço ocupado por uma população relativamente grande, permanente e socialmente heterogênea, no qual existem atividades residencial, de governo, industrial e comercial, com um grau de equipamento e de serviços que assegure as condições de vida humana. A cidade é o lugar geográfico onde se manifestam, de forma concentrada, as realidades sociais econômicas, políticas e demográficas de um território" (Sahop 1978). 
CONSELHO NACIONAL DO MEIO AMBIENTE (CONAMA) - Criado pela Lei de Política Nacional do Meio Ambiente, teve sua composição, organização, competência e funcionamento estabelecidos pelo Poder Executivo através do Decreto $n^{\circ} 88.351$ de 01.06.83 e modificados pelo Decreto n091.305 de 03.06.85. As Competências do CONAMA incluem o estabelecimento de todas as normas técnicas e administrativas para a regulamentação e a implementação da Política Nacional do Meio Ambiente e a decisão, em grau de recurso, das ações de controle ambiental (Lei nº 6.938 de 31.08.81).

CONSERVAÇÃO - O conceito de conservação aplica-se à utilização racional de um recurso qualquer, de modo a se obter um rendimento considerado bom, garantindo-se, entretanto, sua renovação ou sua auto-sustentação. Assim, a conservação do solo é compreendida sua exploração agrícola, adotando-se técnicas de proteção contra erosão e redução da fertilidade. Analogamente, a conservação ambiental quer dizer o uso apropriado do meio ambiente dentro dos limites capazes de manter sua qualidade e seu equilíbrio, em níveis aceitáveis. "A proteção de recursos naturais renováveis e seu manejo para utilização sustentada e de rendimento ótimo" (ACIESP 1980).

CONTROLE AMBIENTAL - "De um modo geral, a faculdade de a administração pública exercer a orientação, correção, a fiscalização e a monitoragem sobre as ações referentes à utilização dos recursos ambientais, de acordo com as diretrizes técnicas e administrativas e as leis em vigor" (FEEMA 1992). "Conjunto de ações tomadas visando a manter em níveis satisfatórios as condições do ambiente" (Lima e Silva 1999). 
DESCENTRALIZAÇÃO - "passagem do planejamento e execução de ações para as esferas estaduais e municipais, sob orientação e assistência técnica, quando necessária, do Governo Federal" (COPASAD 1995).

DESENVOLVIMENTO URBANO - "Processo de adequação e ordenamento, através da planificação do meio urbano, em seus aspectos físicos, econômicos e sociais; implica ainda expansão física e demográfica, incremento das atividades produtivas, melhoria de condições sócio-econômicas da população, conservação e melhoramento do meio ambiente e manutenção das cidades em boas condições de funcionamento" (Sahop 1978).

DIREITO AMBIENTAL, DIREITO DO AMBIENTE - "Distingue-se de legislação ambiental, por considerar, além do conjunto de textos dos diplomas e normas legais em vigor, as jurisprudências e demais instrumentos da ciência jurídica aplicados ao meio ambiente" (FEEMA 1992). "Complexo de princípios e normas reguladoras das atividades humanas que, direta ou indiretamente, possam afetar a sanidade do ambiente em sua dimensão global, visando à sua sustentabilidade para as presentes e futuras gerações" (Milaré 2000).

EDUCAÇÃO AMBIENTAL - "Entendem-se por educação ambiental os processos por meio dos quais o indivíduo e a coletividade constroem valores sociais, conhecimentos, habilidades, atitudes e competências voltadas para a conservação do meio ambiente, bem de uso comum do povo, essencial à sadia qualidade de vida e sua sustentabilidade (Lei Federal 9.795 de 1999). 
GÊNERO - "as relações socialmente construídas entre os dois sexos. É considerado dever do Estado garantir as condições de igualdade de oportunidades no acesso aos benefícios e serviços públicos" (COPASAD 1995).

GESTÃO AMBIENTAL - "É o ato de gerir o ambiente, isto é, o ato de administrar dirigir ou reger partes constitutivas do meio ambiente. Para entender a abrangência e o alcance dessa definição destaca-se que gestão ambiental é o ato de administrar, dirigir ou reger os ecossistemas naturais e sociais em que se insere o homem, individual e socialmente, num processo de interação entre as atividades que exerce, buscando a preservação dos recursos naturais e das características essenciais do entorno, de acordo com padrões de qualidade. O objetivo último é estabelecer, recuperar ou manter o equilíbrio entre a natureza e o homem (Coimbra 1985). "Implementação de políticas públicas com participação comunitária" (Milaré 2000).

GESTÃO COLEGIADA - "instrumento básico de articulação entre as diversas esferas de governo e a participação da sociedade na formulação e controle das políticas públicas e das práticas institucionais" (COPASAD 1995).

GOVERNABILIDADE - "capacidade de tomada de decisão e execução de políticas públicas de forma democrática, eficiente e eficaz, respeitando-se os direitos do cidadão. Esse conceito não é equivalente à expressão de língua inglesa "good governance", que pode se restringir a questões específicas, tais como controle da corrupção" (COPASAD 1995). 
GRUPOS VULNERÁVEIS - "categorias populacionais que muitas vezes são excluídas ou têm acesso precário aos serviços sociais ou de saúde, tais como mulheres rurais, pobres e crianças em situações especialmente difíceis" (COPASAD 1995).

IMPACTO AMBIENTAL - "Qualquer alteração das propriedades físicas, químicas e biológicas do meio ambiente, causada por qualquer forma de matéria ou energia resultante das atividades humanas que, direta ou indiretamente, afetem: (I) a saúde, a segurança e o bem-estar da população; (II) as atividades sociais e econômicas; (III) a biota; (IV) as condições estéticas e sanitárias do meio ambiente; (V) a qualidade dos recursos ambientais" (Resolução CONAMA $n^{\circ}$ 001 de 23.01.86).

INTERDISCIPLINAR - "(1) objeto observado por vários universos disciplinares, com integração dos respectivos domínios lingüísticos de cada disciplina, permitida, facilitada e orientada pela existência de uma temática comum, com a qual as disciplinas deverão observar o objeto. Esse modo exige a cooperação e a coordenação entre disciplinas" (2) "articulação de diversas disciplinas para melhor compreender e gerir situações de acomodação, tensão ou conflito explícito entre as necessidades, as práticas humanas e as dinâmicas naturais" (Philippi, Tucci, Hogan, Navegantes 2000).

LEGISLAÇÃO AMBIENTAL - "Conjunto de regulamentos jurídicos especificamente dirigidos às atividades que afetam a qualidade do meio ambiente" (Shane apud Interim Mekong Committee 1982). 
MULTIDISCIPLINAR - "objeto observado por vários universos disciplinares, determinando dimensões de realidade, cada uma com seus respectivos domínios lingüísticos, justapostos pelo trabalho de revisão de um coordenador. Neste modo não há cooperação entre disciplinas, mas há coordenação" (Philippi, Tucci, Hogan, Navegantes 2000).

PARCERIA - "cooperação entre entidades governamentais e não governamentais, para atingir objetivos estabelecidos de comum acordo, não se restringindo à simples prestação de serviços pelas não governamentais" (COPASAD 1995).

PARTICIPAÇÃO DA SOCIEDADE - "integração de setores não governamentais no processo decisório, diretamente ou através de representantes legítimos, de forma organizada e duradoura. Não se consideram como participação, nesse caso, meros processos de informação, consulta eventual ou envolvimento simbólico de indivíduos sem representatividade" (COPASAD 1995).

PESQUISA POR AMOSTRAGEM - Processo ou método de conceber um número finito de indivíduos ou casos de uma população ou universo, para produzir um grupo representativo. Usado em circunstâncias em que é difícil obter informações de todos os membros da população, como, por exemplo, análises biológicas, controle de qualidade industrial e levantamento de dados sociais. "É um método indutivo de conhecimento de todo o universo estatístico, através de um número representativo de amostras aleatórias desse universo" (Ferrari 1979). 
PLANEJAMENTO PARTIPATIVO - "planejamento estratégico de ações públicas ou privadas de forma não corporativista e com participação da sociedade" (COPASAD 1995).

PRINCÍPIO POLUIDOR PAGADOR - "Princípio que estabelece que o poluidor deve assumir os custos necessários à prevenção e ao combate da poluição, custos esses determinados pelo poder público, a partir de objetivos coletivos de qualidade ambiental. Não se trata de uma compensação por danos causados pela poluição, mas de um princípio de alocação de custos (o custo da "poluição" deve necessariamente repercutir nos custos dos bens e serviços fornecidos)" (COPASAD 1995).

QUALIDADE AMBIENTAL - "Os juízos de valor adjudicados ao estado ou condição do meio ambiente, no qual o estado se refere aos valores (não necessariamente numéricos) adotados em sua situação e um momento dados, pelas variáveis ou componentes do ambiente que exercem uma influência maior sobre a qualidade de vida presente e futura dos membros de um sistema humano" (Gallopin 1981).

RESÍDUOS SÓLIDOS - "Compreendem todos os restos domésticos e resíduos não perigosos, tais como os resíduos comerciais e institucionais, o lixo da rua e os entulhos de construção. Em alguns países, o sistema de gestão dos resíduos sólidos também se ocupa dos resíduos humanos, tais como, excrementos, cinzas de incineradores, sedimentos de fossas sépticas e instalações de tratamento de esgoto. Se manifestarem características perigosas, esses resíduos devem ser tratados como resíduos perigosos" (CNUMAD 1992). 
RESPONSABILIDADE PÚBLICA - "Obrigação de prestar contas publicamente, tanto das atividades realizadas quanto dos recursos financeiros utilizados, seja de órgãos públicos ou entidades privadas ("accountability", nos documentos internacionais)" (COPASAD 1995).

SANEAMENTO - "conjunto de ações, obras e serviços considerados prioritários em programas de Saúde Pública, definidos como aqueles que envolvam: a) abastecimento de água - em quantidade suficiente para assegurar a higiene e o conforto, com a qualidade compatível com os padrões de potabilidade; b) esgotamento sanitário - com soluções sanitárias para casos individuais ou coletivos, fossas, redes coletoras e tratamento; c) resíduos sólidos - armazenamento, coleta, transporte, tratamento e destino final, ambiental e sanitariamente adequado; d) drenagem urbana - com eficiência, sem mistura com esgoto sanitário; e) controle de vetores e roedores - de maneira a quebrar elos na cadeia de transmissão de doenças" "... enquanto campo de intervenção, é o conjunto de ações sócio-econômicas que tem por objetivo alcançar níveis crescentes de salubridade ambiental. O saneamento, nessa acepção, abrange outras questões, como, por exemplo, a poluição do ar e o disciplinamento sanitário do uso do solo, com a finalidade de proteger e melhorar as condições de vida urbana e rural" (COPASAD 1995).

SETORES NÃO GOVERNAMENTAIS - "todas as categorias de atores sociais que não fazem parte das estruturas governamentais, incluindo-se os indivíduos, as famílias, as comunidades, as associações, as cooperativas, as organizações não 
governamentais, as entidades de classe e as empresas" (COPASAD 1995).

SUSTENTABILIDADE - "Qualidade de um sistema que é sustentável; que tenha capacidade de se manter em seu estado atual durante um tempo indefinido, principalmente devido à baixa variação em seus níveis de matéria e energia; desta forma não esgotando os recursos de que necessita" (Lima-e-Silva et al 1999).

TRANSDISCIPLINAR - "construção de um único domínio lingüístico, a partir da identificação de zonas de não resistência epistêmica entre disciplinas, bem como do foco dado pela temática, com o qual se faz, então, a observação do objeto. Esse modo exige a cooperação e a coordenação entre as disciplinas, com 0 objetivo de transcendê-las" (Philippi, Tucci, Hogan, Navegantes 2000).

TRANSPARÊNCIA - "disponibilidade de informação clara e compreensível sobre a organização, as atividades, os resultados e 0 financiamento de uma entidade ou de um programa" (COPASAD 1995).

UNIDISCIPLINAR - "objeto observado por apenas um universo disciplinar, determinando uma única dimensão de realidade e um único domínio lingüístico" (Philippi, Tucci, Hogan, Navegantes 2000).

VIGILÂNCIA EPIDEMIOLÓGICA - "conjunto de ações que proporciona o conhecimento, a detecção ou prevenção de qualquer mudança nos fatores determinantes e condicionantes de saúde individual ou coletiva, com a finalidade de recomendar 
e adotar as medidas de prevenção e controle das doenças ou agravos" (COPASAD 1995). 


\section{SIGLAS E ABREVIATURAS}




\section{SIGLAS E ABREVIATURAS}

ABES - Associação Brasileira de Engenharia Sanitária e Ambiental

ANAMMA - Associação Nacional de Municípios e Meio Ambiente

ARIE - Áreas de Relevante Interesse Ecológico

CADES - Conselho Municipal do Meio Ambiente e Desenvolvimento

Sustentável de São Paulo

CEDA - Curso de Especialização em Direito Ambiental

CEEA - Curso de Especialização em Educação Ambiental

CEGA - Curso de Especialização em Gestão Ambiental

CEESB - Curso de Especialização em Engenharia de Saneamento Básico

CETESB - Companhia de Tecnologia de Saneamento Ambiental

CIESP - Confederação das Indústrias do Estado de São Paulo

CNUMAD - Conferência sobre Meio Ambiente e Desenvolvimento

CONAMA - Conselho Nacional do Meio Ambiente

CONSEMA / SP - Conselho Estadual do Meio Ambiente de São Paulo

DOESP - Diário Oficial do Estado de São Paulo

EIA - Estudo de Impacto Ambiental

FAU - Faculdade de Arquitetura e Urbanismo

FD - Faculdade de Direito

FIESP - Federação das Indústrias do Estado de São Paulo

FSP - Faculdade de Saúde Pública

FEEMA - Fundação Estadual de Engenharia do Meio Ambiente

HSA - Departamento de Saúde Ambiental da Faculdade de Saúde Pública

IBAMA - Instituto Brasileiro do Meio Ambiente e Recursos Naturais Renováveis

ISO - International Standartization for Organization

MCT - Ministério da Ciência e Tecnologia

MMA - Ministério do Meio Ambiente

NACE - Núcleo de Apoio a Cultrura e Extensão

NISAM - Núcleo de Informações em Saúde Ambiental da USP 
ONG - Organização não Governamental

ONU - Organização das Nações Unidas

PADCT - Programa de Apoio ao Desenvolvimento Científico e Tecnológico

PMSP - Prefeitura do Município de São Paulo

PND - Plano Nacional de Desenvolvimento

PNUD - Programa das Nações Unidas para o Desenvolvimento

PNUMA - Programa das Nações Unidas para o Meio Ambiente

PROISA - Programa de Informações em Saúde e Ambiente da USP

RIMA - Relatório de Impacto Ambiental

RMSP - Região Metropolitana de São Paulo

SABESP - Companhia de Abastecimento de Água do Estado de São Paulo

SEPURB - Secretaria de Política Urbana do Ministério do Planejamento e do Orçamento

SERPHAU - Serviço de Patrimônio Histórico

SMA - Secretaria do Meio Ambiente do Estado de São Paulo

SNUC - Sistema Nacional de Unidades de Conservação

SISNAMA - Sistema Nacional do Meio Ambiente

SVMA - Secretaria do Verde e do Meio Ambiente, hoje SMMA - Secretaria

Municipal do Meio Ambiente de São Paulo

USP - Universidade de São Paulo 


\section{ÍNDICE REMISSIVO \\ FIGURAS, TABELAS E \\ QUADROS}




\section{ÍNDICE REMISSIVO - FIGURAS}

\section{CAPÍTULO 2}

Figura 2.1 - Composição multidisciplinar dos cursos de gestão ambiental

\section{CAPÍTULO 4}

..p.

Figura 4.1 - Número de alunos de acordo com a formação profissional (CEGA-1)

Figura 4.2 - Alunos por gênero (CEGA-1)

Figura 4.3 - Número de alunos de acordo com a formação profissional (CEGA-2)

Figura 4.4 - Alunos por gênero (CEGA-2)

Figura 4.5 - Número de alunos de acordo com a formação profissional (CEGA-3)

Figura 4.6 - Alunos por gênero (CEGA-3)

Figura 4.7 - Número de alunos de acordo com a formação profissional (CEGA-4)

Figura 4.8 - $\quad$ Alunos por gênero (CEGA-4)

Figura 4.9 - Número de alunos com a formação profissional (CEGA-5)

Figura 4.10 - Alunos por gênero (CEGA-5)

Figura 4.11 - Número de alunos de acordo com a formação profissional (CEGA-6)

Figura 4.12 - Alunos por gênero (CEGA-6)

Figura 4.13 - Número de alunos de acordo com a formação profissional (CEGA-7)

Figura 4.14 - Alunos por gênero (CEGA-7)

Figura 4.15 - Número de alunos de acordo com a formação profissional (CEGA-8)

Figura 4.16 - Alunos por gênero (CEGA-8)

Figura 4.17 - Número de alunos de acordo com a formação profissional (CEGA-9)

Figura 4.18 - Alunos por gênero (CEGA-9)

Figura 4.19 - Número de alunos de acordo com a formação profissional (CEGA-10)

Figura 4.20 - Alunos por gênero (CEGA-10)

Figura 4.21 - Número de alunos de acordo com a formação profissional (CEGA-11)

Figura 4.22 - Alunos por gênero (CEGA-11) 
Figura 4.23 - Número de alunos de acordo com a formação profissional 4.24 (CEGA-12)

Figura 4.24 - Alunos por gênero (CEGA-12) 4.25

Figura 4.25 - Número de alunos de acordo com a formação profissional 4.26 (CEGA-13)

Figura 4.26 - Alunos por gênero (CEGA-13) 4.27

Figura 4.27 - Formação profissional dos ex-alunos CEGA-1 - CEGA-13 4.36

Figura 4.28 - Variação no genêro CEGA-1 - CEGA-13 4.37

Figura 4.29 - Local de atuação dos ex-alunos CEGA-1 - CEGA-13 4.38

Figura 4.30 - Municípios de atuação dos ex-alunos 4.39

Figura 4.31 - Atuação na área ambiental CEGA-1 - CEGA-13 4.40

Figura 4.32 - Setor de atuação CEGA-1 - CEGA-13 4.41

Figura 4.33 - Atuação dos entrevistados $\quad 4.43$

Figura 4.34 - Setores de atuação $\quad 4.44$

Figura 4.35 - Forma de pensar dos alunos após conclusão do curso $\quad 4.45$

Figura 4.36 - Mudanças na atuação dos entrevistados após a conclusão do $\quad 4.46$ CEGA

Figura 4.37 - Opinião dos entrevistados sobre a contribuição do curso para 4.47 a ascensão profisssional na carreira

Figura 4.38 - Impacto do conhecimento dos alunos nos locais de trabalho 4.48

Figura 4.39 - Difusão dos conhecimentos adquiridos no CEGA 4.49

Figura 4.40 - Forma de difusão dos conhecimentos $\quad 4.50$

Figura 4.41 - Importância do conhecimento obtido no CEGA para a atuação 4.52 profissional presente

Figura 4.42 - Áreas em que o entrevistado atuou ou está atuando $\quad 4.54$

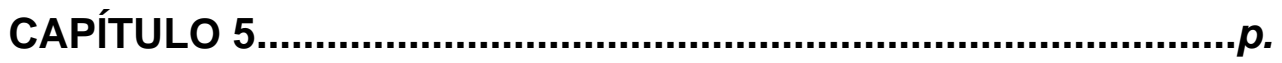

Figura 5.1- Perfil do aluno típico - CEGA-1 CEGA-13 5.2

Figura 5.2 - Variação de atuação na área ambiental $\quad 5.4$

Figura 5.3 - Variação de atuação por setor $\quad 5.4$

Figura 5.4 - Variação de atuação por setor $\quad 5.5$

Figura 5.4 - Mapas de atuação regional $\quad 5.6$ 


\section{CAPÍTULO 2..................................................................................p.}

Tabela 2.1 - Alterações sofridas nos cursos CEGA de 1995 a 2001

CAPÍTULO 3...........................................................................p.

Tabela 3.1 - Distribuição dos ex-alunos dos CEGAs 3.2

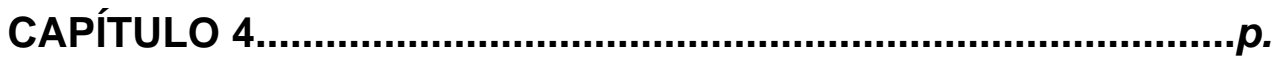

Tabela 4.1 - Trabalhos finais de conclusão de curso agrupados por área 4.28 de conhecimento

ÍNDICE REMISSIVO - QUADROS

CAPÍTULO 2..........................................................................p.

Quadro 2.1 - Estrutura circular CEGA-9 ao CEGA-13 2.21 


\section{ANEXOS}

1. ESTRUTURA CURRICULAR E CONTEÚDO PROGRAMÁTICO DOS CURSOS CEGA - VIGENTE, p.A 1

2. MODELO DE QUESTIONÁRIO DE AVALIAÇÃO SEMESTRAL DO CURSO, p.A 28

3. MODELO DE QUESTIONÁRIO DE AVALIAÇÃO DE DISCIPLINA, p.A 31

4. PLANILHA COM OS RESULTADOS DA TABULAÇÃO DE DADOS DE DISCIPLINA DO CURSO, p.A 34

5. ROTEIRO DE ENTREVISTA FINAL APLICADO NESTA PESQUISA, p.A 36

6. DADOS CADASTRAIS DOS ALUNOS (CEGA 1 - CEGA 13), p.A 40

7. OPÇÕES TEMÁTICAS DAS MONOGRAFIAS (CEGA1- CEGA 13), p.A 54 


\section{ANEXO 1 \\ ESTRUTURA CURRICULAR E CONTEÚDO PROGRAMÁTICO DOS CURSOS CEGA - VIGENTE}




\section{CONTEÚDO PROGRAMÁTICO DAS DISCIPLINAS}

MÓDULO I BÁSICO: FUNDAMENTAÇÃO DO CONTROLE AMBIENTAL. $[168 \mathrm{~h}]$

1. SANEAMENTO AMBIENTAL E ECOLOGIA APLICADA

$(24 h)$

Professor Responsável: Arlindo Philippi Jr

\section{Conteúdo Programático:}

- Meio ambiente, Saneamento do Meio e Saúde Pública: objetivos e inter-relacionamento.

- Conceitos de Ecologia. A Questão Ambiental no Brasil. Impactos dos ecossistemas urbanos sobre as comunidades. Saneamento Básico: Sistemas de Limpeza Pública.

- Efeitos da Ação Antrópica sobre o Meio Ambiente. Modificações Ambientais e Aparecimento de Doenças.

- Saneamento Básico: aspectos gerais, características, sistemas e soluções.

- Artrópodes e Roedores de Importância em Saúde Pública. Aspectos Sanitários e Econômicos, Biologia e Ações de Controle.

- Ações e Estratégias frente a Situações de Emergência.

- Serviços Básicos de Saneamento em Situação de Emergência.

- Saneamento em Emergência Ambiental: Ações e Serviços Básicos.

- Interações e Estratégias de Intervenção no Ambiente para Redução de Efeitos das Modificações Ambientais sobre a Saúde. Desafios e enfrentamentos.

- Programas de Saneamento Ambiental e Ação Comunitária. Seminário.

\section{Bibliografia:}

Alves AC. Lógica: pensamento formal e argumentação - elementos para o discurso jurídico. Bauru, São Paulo: Edipro, 2000.

Boff L. Saber cuidar: ética do humano - compaixão pela terra. Petrópolis, Rio de Janeiro: Editora Vozes, 1999.

Compromisso Empresarial para Reciclagem -CEMPRE. O papel da Prefeitura. São Paulo; 1993.

Brasil. Constituição da República Federativa do Brasil. Brasília: Senado Federal; 1988.

Hogan DJ, Vieira PF. Dilemas socioambientais e desenvolvimento sustentável. Campinas, São Paulo: Editora da Unicamp; 1995.

Instituto de Pesquisas Tecnológicas - IPT, Compromisso Empresarial para Reciclagem CEMPRE. Lixo municipal: manual de gerenciamento integrado. São Paulo: IPT; 1995.

Jorge MHPM, Gotlieb SLD. As condições de saúde no Brasil: retrospecto de 1979 a 1995. Rio de Janeiro: Editora Fiocruz, 2000.

Leff E. Saber ambiental: sustentabilidade racionalidade complexidade poder. Petrópolis, Rio de Janeiro: Editora Vozes, 2001.

Ministério da Saúde. Plano nacional de saúde e ambiente no desenvolvimento sustentável: diretrizes para implementação. In: Conferência Pan-Americana sobre Saúde e Ambiente no Desenvolvimento Humano Sustentável; 1995 jul; Brasília [DF]. Brasília; 1995. 
Philippi Jr. A, Brunaci A, Andreoli CV, Moreira IVD, coordenadores. Brasil'92: perfil ambiental e estratégias. São Paulo: Secretaria de Estado do Meio Ambiente; 1992.

Philippi JR. A, coordenador. Agenda 21 Local: Compromisso do Município de São Paulo. São Paulo: Secretaria Municipal do Verde e do Meio Ambiente; 1996.

Mota S. Urbanização e meio ambiente. Rio de Janeiro: Associação Brasileira de Engenharia Sanitária e Ambiental; 1999.

Philippi Jr. A, organizador. Saneamento do meio. São Paulo: FUNDACENTRO; 1988.

Philippi Jr. A, Elias EO, coordenadores. A questão ambiental urbana: cidade de São Paulo. São Paulo: Secretaria Municipal do Verde e do Meio Ambiente; 1993.

Rebouças AC, Braga B, Tundisi JG. Águas doces no Brasil: capital ecológico, uso e conservação. São Paulo: Escrituras Editora, 1999.

Reigota M. Educação ambiental e representação social. São Paulo: Cortez; 1997.

2. CONTROLE AMBIENTAL - I - ÁGUA

Professor Responsável: Lineu José Bassoi

\section{Conteúdo Programático:}

- Situação atual da poluição das águas no Estado de São Paulo. Monitoramento da Qualidade das Águas IQA.

- Recursos Hídricos e seus usos: qualidade e quantidade das águas. Fontes e efeitos da poluição.

- Classificação dos corpos d'água. Padrões de emissão e de qualidade

- Fontes de poluição das águas. Causas e efeitos da poluição.

- Programas de prevenção e controle de poluição das águas.

- Métodos e controle da poluição das águas. Programas de controle nas indústrias.

- Legislação relativa à proteção das águas.

\section{Bibliografia:}

Mara DD, Silva SA. Tratamento biológico de águas residuárias; lagoas de estabilização. Rio de Janeiro: ABES; 1979.

Metcalf L, Eddy HP. Wastewater engineering treatment disposal reuse. $3^{\text {rd }}$.ed New York: McGraw-Hill; 1992.

Monod J. The growth of bacterial cultures. Ann. Inst. Pasteur 1941; 371-93 apud Vazoller RF, Garcia AD. et.al. Microbiologia de lodos ativados. São Paulo: CETESB; 1989. (Série anuais/CETESB). P.1-22 1989.

Mota S. Preservação de recursos hídricos. Rio de Janeiro: ABES; 1988.

Ogera RC. Remoção de nitrogênio do esgoto sanitário pelo processo de lodo ativado por batelada. Campinas; 1995. [Dissertação de Mestrado - Faculdade de Engenharia Civil Universidade Estadual de Campinas].

Pessôa CA, Jordão EP. Tratamento de esgotos domésticos. Rio de Janeiro: ABES;1982. V. I. 


\section{Conteúdo Programático:}

- Características da atmosfera. Padrões aplicáveis ao controle da poluição do ar.

- Situação atual da poluição do ar no Brasil. Poluição global. Efeitos da poluição no ar.

- Fontes e poluentes. Fatores de emissão. Amostragem de poluentes.

- Meteorologia e dispersão de poluentes na atmosfera.

- Controle de poluição do ar: medidas aplicáveis e análise de sistemas de controle de poluição do ar.

- Ruído e vibração.

\section{Bibliografia:}

Assunção JV. Efeito da redução da camada de ozônio sobre o meio ambiente. São Paulo. Gerência de Risco 1990; 5 (20); 30 - 6.

Bohm GM. Impactos da poluição dos veículos automotores na saúde humana e meio ambiente. In: Avaliação do PROÁLCOOL, FIESP-CIESP, junho de 1986.

Braile, V.V. Controle da poluição do ar no Estado do Rio de Janeiro. São Paulo, [Apresentado no Encontro Internacional sobre Vigilância da Qualidade do $\mathrm{Ar}$ OPAS/CETESB; 10/85]

Branco GM, Szwarc A. O Proconve e o controle da poluição do ar. São Paulo: CETESB, 1988. [Apresentado no $6^{\circ}$ Simpósio Nipo-Brasileiro; 1988

Brown LR, organizador. Salve o planeta: qualidade de vida. Rio de Janeiro: Worldwtch Institute/Editora Globo; 1990.

Chow S. Some aspects of the urban climate of Sahanghai. In: Proceedings of the Urban Climatology and its Application with Special Regard to Tropical Areas; 1984; nov 2630; México [DF]. (WNO Tech. note , 652).

Companhia de Tecnologia de Saneamento Ambiental - CETESB .Ação da CETESB em Cubatão: situação em janeiro de 1991. São Paulo; 1991.

Companhia de Tecnologia de Saneamento Ambiental - CETESB. Relatório de qualidade do ar no Estado de São Paulo. São Paulo.

COPERSUCAR. Pró-álcool: fundamentos e perspectivas. São Paulo; 1989.

Daniello JA. Integração indústria/comunidade. São Paulo, 1985. [Apresentado ao Seminário Eliminação de Odores em Fábricas de Papel e Celulose ABCP; 1985 mar]

Fisher FM \& Hofmeister VA. The effects of air pollution at different seasons on lung function of normal schoolchildren in Cubatão (SP Brazil). In: Manninen O, Okada A. Recent advances in researches on the combined effects of environmental factors. Kanazawa: Ed. Kyoei; 1987.

Galvão Filho JB, Campos MAV, Diez JM. Plano de ação para controle da poluição do ar em Cubatão. [Apresentado ao $12^{\circ}$ Congresso Brasileiro de Engenharia Sanitária e Ambiental. 1983.

Godinho R, Acquaviva W, Romano J. Ocorrência de aldeídos na atmosfera da Grande São Paulo. [Apresentado ao $11^{\circ}$ Congresso Brasileiro de Engenharia Sanitária e Ambiental; 1981.

Godish T. Air quality. Chelsea : Lewis ; 1991.

Goldenberg J. S.OS. Planeta Terra. São Paulo: Brasiliense; 1990. 
Guimarães FA, Galvão Filho JB, Campos MAV, Godinho R, Oliveira S. Plano de ação de emergência para prevenção de episódios críticos de poluição do ar em Cubatão. São Paulo: CETESB; 1984.

Haag PH, coordenador. Chuvas ácidas. Campinas :Fundação Cargill; 1985.

Kemp DD. Global environmental issues: a climatological approach. London: Routledge; 1990.

Kirchoff VWJH. A redução da camada de ozônio, efeitos sobre o Brasil. Eng Amb 1989; 2(7):

Libanori A. A aplicação de mecanismos econômicos na política de controle de poluição. São Paulo; 1990. [Dissertação de Mestrado - Pontificia Universidade Católica de São Paulo]

Licco EA. Filosofias para controle da poluição ambiental. São Paulo: CETESB; 1991.

Magalhães JP de A, Kuperman N, Machado RC. Pró-Alcool: uma avaliação global. Rio de Janeiro: Astel; 1991.

Mello WZ, Motta JST. Chuva ácida. Ciênc Hoje 1987; 6(34):

Mendes R; Wakmatsu CT. Avaliação dos efeitos agudos da poluição do ar sobre a saúde, através do estudo da morbidade diária em São Caetano do Sul: estudo preliminar, relatório. São Paulo: CETESB; 1976.

Mesquita ALS, Santos JCD, Queiroz LA. Estratégias alternativas para o controle de dióxido de enxofre na Região da Grande São Paulo. [Apresentado ao $11^{\circ}$ Congresso da ABES, 1981.

Nefussi N, Assunção JV, Toldedo MP, Castelli AS. Comparação entre emissões de poluentes de veículos a álcool e a gasolina. [Apresentado no $11^{\circ}$ Congresso da ABES, 1981.

Nogueira DP. Efeitos da poluição do ar sobre a saúde. São Paulo, 1966. [Apresentado ao Seminário sobre Poluição do Ar, 1966, mês? Dia? São Paulo, Brasil. Revisto e atualizado].

Padmanabhmurty B. Some aspects of the urban climates of India. In: Proceedings of the Urban Climatology and its Application with Special Regard to Tropical Areas; 1984; nov 26-30; México [ DF]. (WNO Tech. Note, 652).

Petróleo Brasileiro S.A. (PETROBRÁS). Manual de produtos de petróleo. Rio de Janeiro; 1990.

Pinho Filho P. A qualidade do ar no Estado do Rio de Janeiro. [Apresentado ao 20 Congresso de Pneumologia e Tisiologia do Rio de Janeiro - $2^{\mathrm{a}}$ Jornada de Pneumologia Infantil do Rio de janeiro, 1989 set ; Rio de Janeiro; Brasil] .

Pompéia SL, Pradella DZA, Martins SE, Santos RC, Diniz KM. A semeadura aérea na Serra do Mar em Cubatão. Ambiente 1989; 3 (1).

Rancevas, S. Riscos ambientais decorrrentes da utilização de energias alternativas: o controle da poluição do ar na Região Metropolitana de São Paulo e avaliações através de estudos de associações entre dados de concentrações ambientais de dióxido de enxofre com indicadores de saúde relativos a doenças respiratórias. São Paulo, 1990. [Dissertação de Mestrado - Faculdade de Saúde Pública da USP].

Ribeiro HP et al. Estudo da função ventilatória em escolares vivendo com diferentes níveis de poluição do ar: relatório; 1976.

Setzer A. In: Vieira, C.L. Fumaça faz Amazônia parecer um vulcão. Folha de São Paulo, 1991 out 10; caderno?

Stern AC. Fundamentals of air pollution. New York : Academic Press; 1982. 
Wodtke M. Brasil é o terceiro responsável pelo efeito estufa. Jornal o Brasil, 1990 jul 7.

\section{CONTROLE AMBIENTAL III - RESÍDUOS}

Professora Responsável: Wanda Maria Risso Günther

\section{Conteúdo Programático:}

- Resíduos Sólidos: conceituação, classificação, composição e análise. Aspectos sanitários, epidemiológicos, sócio-econômicos e ambientais.

- Serviços de Limpeza Pública. Sistema de Resíduos Sólidos.

- Acondicionamento, coleta e transporte e tratamento.

- Sistema de Resíduos Sólidos: tratamento, compostagem, incineração e disposição final.

- Minimização e Reciclagem de Resíduos. Resíduos Indústriais: segregação, acondicionamento, armazenamento e transporte.

- Resíduos sólidos industriais: métodos de tratamento e disposição final. Análise e avaliação de projetos e sistemas de controle.

\section{Bibliografia:}

Fenn DG, Hanley $\mathrm{K} \mathrm{J}$, De G, Truett $\mathrm{V}$. Use of the water balance method for predicing leachate generation from solid waste disposal sites. 1975 (Environmental Protection Agency Report SW. 168.1975).

Gloeden E. Técnicas de monitoramento das zonas não saturadas. São Paulo: CETESB; 1988.

Gomes DC. Avaliação hidrogeológicas de locais para implantação de aterros. São Paulo: CETESB; 1988.

Mendes JMB. Métodos geofísicos aplicados à investigação da poluição das águas subterrâneas. São Paulo: CETESB; 1989.

Rocca ACC, Narchi H, Nabhan MLGLNM, Neto PPC. Drenagem em aterro sanitários. São Paulo: CETESB; 1979.

Silva LM. Critérios geológicos básicos para a seleção de áreas para aterros sanitários. São Paulo: CETESB; 1986. 
Professora Responsável: Vera Lucia Ramos Bononi

\section{Conteúdo Programático:}

- Avaliação do interesse e heterogeneidade dos estudantes. Seres vivos; animais, vegetais e microrganismos. Biodiversidade in situ, ex sito (coleções, Herbário, Museus, Culturas e Bancos Genéticos).

- A pesquisa, levantamentos, inteirações ecológicas e sucessão. Principais Biomas brasileiros e os Biomas do Estado de São Paulo.

- Espécies selvagens e introduzidas. Ecossistemas aquáticos e Bacias Hidrográficas. Sistema Nacional e Estadual do Meio Ambiente. Educação Ambiental e Cooperação Internacional.

- Proteção da Flora e Fauna fora de áreas especialmente protegidas. Principal legislação: Código Florestal, Decreto 750, Constituição Federal e Estatual. Órgãos responsáveis pela fiscalização e licenciamento ambiental a nível federal, estadual e municipal.

- Visita Técnica ao Instituto Florestal e Parque Estadual Alfredo Loefgren. Rua do Horto, no 931.

- Proteção in situ. Unidades de Conservação Nacionais, Estaduais e Municipais. Gestão das Unidades de Conservação e seu entorno. Reserva da Biosfera. Áreas tombadas. Vegetação imune ao corte. Espécies ameaçadas de extinção. Terceirizações.

- Recuperação de áreas degradadas. Vegetação primária, secundária e climax. Modelos. Planos de recuperação. Valoração de áreas naturais. Licenciamentos e minimização ou compensação ambiental. Prevenção a poluição e poluição ambiental, efeito nos seres vivos. Transgênicos.

- Estudo Dirigido/Visita Técnica ao Parque Ibirapuera: Viveiro Manequinho Lopes e Divisão de Fauna Silvestre e Medicina Veterinária Preventiva.

- $\quad$ Arborização Urbana. A mídia e as áreas. verdes. Prova incluindo conclusões das visitas técnicas e estudos dirigidos.

\section{Bibliografia:}

Ab'Saber A. Contribuição a geomorfologia das áreas dos cerrados. In: Ferri MG, coordenador. Simpósio sobre cerrado. São Paulo: Edgard Blucher / Editora da Universidade de São Paulo; 1971. p. 98-103.

Assis C, Toledo CB, Romaniuc Neto S, Cordeiro I. Coleção nossas plantas: Amazônia, Mata Atlântica, Cerrado, Pantanal, Matas de Araucária e Caatinga. São Paulo: FTD; 1994.

Aubréville A. As florestas do Brasil: estudo fitogeográfico e florestal. Anuário Bras. Economia Florestal 1959; 10:57-72.

Barbosa LM, Asperti LM, Barbosa JM. 1996: Características importantes de componentes arbóreos na definição dos estágios sucessionais em florestas implantadas. In: Anais do $4^{\circ}$ Simpósio Internacional de Ecossistemas Florestais; 1996; p. 242-245.

Barbosa LM, Serra Filho R, coordenadores. Desenvolvimento e implantação de modelos alternativos de recomponsição vegetal com espécies nativas na fazenda São Carlos Santa Cruz das Palmeiras - SP. São Paulo: Instituto de Botânica/ SMA; 1993.

Barbosa LM. Estudos interdisciplinares do Instituto de Botânica em Moji-Guaçu, SP. In: Simpósio sobre Mata Ciliar. Campinas: Fundação Cargill; 1989. p. 171-91. 
Barbosa LM, coordenador. Anais do Simpósio sobre Mata Ciliar. Campinas: Fundação Cargill; 1989.

Barbosa LM et al, coordenador. Resumos do Simpósio obre Mata Ciliar. 1995, Ribeirão Preto. Resumos , $46^{\circ}$ Congresso Nacional de Botânica, 416p.

Bezerra dos Santos L. Floresta de Galeria. In: Tipo e aspectos do Brasil. $10^{\mathrm{a}}$ ed. Rio de Janeiro: Fundação Instituto Brasileiro de Geografia e Estatística; 1975. p. 482-4.

Budowski $G$. The distinction between old secondary and climax species in tropical Central American Lowland Forest. Trop Ecol 1970; 11 (1): 45-8.

Campos LFG. Mapa florestal. Ed. Fac-similar 1987. São Paulo: Secretaria do Estado do Meio Ambiente; 1992.

Décamps H, Naiman RJ.. Towards an ecotonoe perspective . In: Naiman RJ, Décamps $H$, editores. The ecology and management of aquatic-terrestrial ecotones: UNESCO/ Parthenon; 1990. p. 1-6 (MAB series, v.4)

Dematttê JLI: Caracterização e formação de solos sob mata ciliar. Resumos; 1989; São Paulo (SP). p. 14.

Denslow JS. Gap partioning among tropical rain forest trees. Biotropica 1980; 12(Suppl.):47-55.

Dias BFS. A convenção sobre a diversidade biológica e sua implantação no Brasil. In: Resumos do $46^{\circ}$ Congresso Nacional de Botânica 1995; Ribeirão Preto (SP). p. 399.

Fevi MG. Vegetação brasileira. São Paulo: Itatiaia/ EDUSP; 1980.

Goodland R. Glossário de ecologia brasileira. Manaus: Instituto Nacional de Pesquisa; 1975.

Hueck K. As florestas da América do Sul. Brasília: Ed. Universidade de Brasília; 1972.

Joly CA. Ecotones at the river basin scale global land/water interactions. In: Jenses A, editor. Proceedings of Ecotones Regional Workshop 1992; Australia. UNESCO/Ecotones Research Project;1994. p. 40-66.

Kageyama PY, coordenador. Estudo para implantação de matas ciliares de proteção na bacia hidrográfica do Passa Cinco visando a utilização para abastecimento público; relatório de pesquisa. Piracicaba: ESALQ/USP/DAEE; 1986.

Kageyama PY, Biella LC, Palermo Jr A. Plantações mistas com espécies nativas com fins de proteção a reservatórios. In: Anais do $6^{\circ}$ Congresso Florestal Brasileiro 1990; Campos do Jordão (SP), 1990. p109-113.

Kageyama PY. Modelos de Revegetação para recuperação de Matas Cilieare. In: Resumos do $46^{\circ}$ Congresso Nacional de Botânica 1995; Ribeirão Preto (SP). 1995. P. 3967.

Macedo AC. Revegetação: matas ciliares e de proteção ambiental. Revisado e ampliado por Paulo Y. Kageyama e Luiz G. S. Costa. São Paulo: Fundação Florestal da SMA; 1993.

Mantovani W. Conceitos e fatores condicionantes. In: Simpósio sobre Mata Ciliar. Campinas: Fundação Cargill; 1989. p. 11-19.

Odum EP. Ecologia. Rio de Janeiro: Editora Guanabara; 1983.

Odum EP. Ecologia Rio de Janeiro: Ed. Guanabra; 1988.

Penteado MM. Fundamentos de geomorfologia. $3^{\mathrm{a}}$ ed. Rio de Janeiro: Fundação IBGE; 1993.

Rodrigues RR, Leitão Filho HF, Crestana MSM.. Recomposição artificial da mata ciliar ao redor da represa de abastecimento de água do município de Iracemápolis, SP. In: Plano diretor de manejo e uso da bacia hidrográfica do Ribeirão Cachoeirinha, município de Iracemápolis, SP. 1987. p. 59-91. 
Swaine MD, Whitmore TC. On the definition of ecological species groups in tropical rain forests. Vegetation 1988; 75:81-86.

Veloso HP. Aspectos fitossociológicos da bacia do Alto Rio Paraguai. Biogeografia 1972; 7:1-31.

\section{6-SISTEMAS DE INTEGRAÇÃO AMBIENTAL}

\section{Professor Responsável: Geol. Valdir Akihiko Nakazawa}

\section{Conteúdo Programático:}

- Introdução: A composição da cidadania: natureza e expectativas.

- Técnicas para produção e gestão de informações ambientais: Sensoriamento Remoto/Sistema de Informação Geográfica.

- Técnicas para produção e gestão de informações ambientais: condicionantes físicas na dinâmica do ambiente urbano.

- Técnicas para produção e gestão de informações ambientais: análise integrada da paisagem

- Instrumentos de Gestão: zoneamento em áreas de uso especial ( APAs, APMs, etc)

- Instrumentos de Gestão: Gestão de Recursos Hídricos.

- Visita Técnica: região do ABC

- Avaliação.

\section{Bibliografia:}

Caubet CG, Frank B. Manejo ambiental em bacias hidrográficas. Florianópolis: Fundação Água Viva; 1993.

CESP. Manejo integrado da bacia do rio Dourado. São Paulo; 1996. (Série Pesquisa e Desenvolvimento, 138).

CESP. Protejo ação institucional para o manejo integrado de bacias hidrográficas: relatório de atividades de 1995. Plano de trabalho - 1996. São Paulo; 1996.

Encontros Preparatórios para o Seminário da bacia do Rio Dourado. Informe Técnico. São Paulo; agosto, 1996. Rança AC de, Faria B, Noffs P da S. Manejo integrado de bacias hidrográficas. São Paulo: CESP; 1992. Série Pesquisa e Desenvolvimento, 67.

Grupo Técnico do Rio Dourado. Relatório técnico. Lins, setembro, 1996.

Lanna AEL. Gerenciamento de bacia hidrográfica - aspectos conceituais e metodológicos. Brasília : Ministério do Meio Ambiente, dos Recursos Hídricos e da Amazônia Legal / IBAMA; 1995.

Unidade de Gerenciamento do Programa de Saneamento Ambiental da Região Metropolitana de Curitiba (UGP / PROSAM) da Secretaria do Planejemento e Coordenação Geral. Modelo de gestão da Bacia do Alto Iguaçu. Curitiba; 1996.

Professora Responsável: Ângela Maria Belloni Cuenca

\section{Conteúdo Programático:}


- Informações gerais sobre sistemas de informação, com ênfase à Biblioteca/CIR. Recuperação da Informação Especializada. Facilidades de acesso à Informação Especializada.

- Modalidades e características das publicações.

- Inform. gerais sobre aspectos normativos de apres. de trabalhos acadêmicos. Normalização de Ref. Bibliográficas.

\section{Bibliografia:}

Carmo-Neto D. Metodologia científica para principiantes. $2^{\mathrm{a}}$ ed. Salvador: Universitária Americana, 1993.

Day RA. Como escribir y publicar trabajos científicos. Washington: Organizacíon Panamericana de la Salud; 1990. (OPS - Publicacíon Científica, 526).

Lakatos EV, Marconi M de A. Fundamentos de metodologia científica. $3^{a}$ ed. São Paulo: Atlas; 1995.

Parker D, Starret B. Guia do CD-ROM. São Paulo: Berkeley; 1995.

Sá ES de. Manual e normalização de trabalhos técnicos, científicos e culturais. Petropólis: Vozes; 1994.

Salomon DV. Como fazer uma monografia: elementos de metodologia de trabalho científico. $3^{\mathrm{a}}$ ed. São Paulo: Martins Fontes; 1994.

Severino AJ. Metodologia do trabalho científico. 18ª ed. São Paulo: Cortez; 1992.

Universidade de São Paulo. Faculdade de Saúde Pública. Biblioteca/CIR. Guia de apresentação de teses. São Paulo; 1998.

Ziman JM. Força do conhecimento: a dimensão científica da sociedade. Belo Horizonte: Itatiaia; 1981. 


\section{LINGUAGEM E PERCEPÇÃO AMBIENTAL}

Professores Responsáveis: Marcelo de Andrade Roméro; José Ávila de A. Coimbra

\section{Conteúdo Programático:}

- Caracterização da Questão Ambiental. Conceitos e terminologia. Confusões, imprecisões e impropriedades conceituais.

- Percepção do Meio Ambiente como realidade física, histórica e social. Alguns tipos de percepção: sensorial, física, social e profissional. Patrimônio Ambiental Nacional.

- Abordagem holística. Visão sistêmica. Tratamento interdisciplinar. Algumas fronteiras científicas mais recentes no tratamento da Questão Ambiental.

- Conceitos, vocábulos e expressões mais usadas na Gestão Ambiental.

\section{Bibliografia:}

Branco, Samuel Murgel: Ecossistêmica: uma abordagem integrada dos problemas do Meio Ambiente. $2^{\mathrm{a}}$ ed. São Paulo: Edgard Blucher, 1999, 202 p.

Capra, Fritjof: A Teia da Vida. São Paulo: Cultrix, 1997, 256 p.

Capra, Fritjof; Stendl - Rast, David; Matus, Thomas: Pertencendo ao Universo.São Paulo: Cultrix, 1993, 193 p.

Dicionário Brasileiro de Ciências Ambientais. Rio de Janeiro: Thex, 1999, 247 p.

Drew, David: Processos interativos Homem - Meio Ambiente. $3^{\text {a }}$ ed. Rio de Janeiro: Bertrand Brasil, 1994, 224 p.

Philippi Jr, Arlindo et alii: Interdisciplinaridade em Ciências Ambientais.São Paulo: Signus, 2000, $318 \mathrm{p}$.

Ribeiro, Maurício Andrés: Ecologizar: pensando o ambiente humano. Belo Horizonte: Roma, 1998, 390 p.

Sheldrake, Rupert: O Renascimento da Natureza. São Paulo; Cultrix, 1993, 236 p.

Thompson, William Irwin (Org.): Gaia, uma teoria do conhecimento. São Paulo: Global / Garcia, 1990, 203 p.

Thoureu, Henry D. :Walden ou a Vida nos Bosques (inclui "A Desobediência Civil"). São Paulo: Aquariana, 2001, $346 \mathrm{p}$.

Tuan Yi-Fu. Topofilia: um estudo da percepção, atitudes e valores do meio ambiente. Trad. L de Oliveira. São Paulo: DIFEL; 1980. 


\section{Professor Responsável: Délsio Natal}

\section{Conteúdo Programático:}

- Conceito de saúde pública. O Sistema Institucional de Saúde Pública no Brasil.

- A relação saúde/doença: associações causais, história natural da doença. A saúde no contexto ambiental urbano. A medida coletiva da doença.

- Método epidemiológico. Epidemiologia descritiva.

- Epidemiologia Paisagística.

- Epidemiologia analítica.

- Doenças transmissíveis e não-transmissíveis.

- Vigilância epidemiológica.

\section{Bibliografia:}

Armijos Rojas R. Epidemiologia. Buenos Aires: Inter-Médica; 1974.

Alvarado CA. Concepto de la salud pública. In: Sounis A et al. Medicina sanitaria y administration de salud. Bueno Aires: Atheneu 1971. V.1

Carvalho FM et al. Intoxicação por chumbo entre crianças de Santo Amaro, Bahia, Brasil. Bol Ofic Sanit Panam 1986; 100 : 309-19.

Costa DC et al. Epidemiologia, teoria e objeto. São Paulo: Hucitec/ABRASCO; 1994.

Coura JR et al. Morbidade da esquistossomose mansoni no Brasil. Mem Inst Oswaldo Cruz 1983; 78: 1-11.

Doll $R$, Hill AB. El habito de fumar y el carcinoma de pulmón: informe preliminar. In: Organizacion Panamericana de la Salud. El desafio de la epidemiologia: problemas y lecturas selecionadas. Washington (DC); 1988. ( OPS - Publicacion Cientifica, 505).

Fletcher RH et al. Epidemiologia clínica. $2^{\mathrm{a}}$ ed. Porto Alegre: Artes Médicas; 1991.

Forattini OP. Ecologia, epidemiologia e sociedade. São Paulo: Artes Médicas/EDUSP; 1992.

Forattini OP. Epidemiologia geral. 2a ed. São Paulo: Artes Médicas; 1996.

Forattini OP. Epidemiologia geral. São Paulo: Artes Médicas; 1980.

Iversson LB. Aspectos epidemiológicos da meningite meningocócica no munícipio de São Paulo (Brasil) no período de 1968 a 1974. Rev Saúde Pública 1976; 10: 1-16.

Leavel H, Clark EG. Medicina preventiva. São Paulo: MacGraw-Hill do Brasil; 1976.

Leser W et al. Elementos de epidemiologia geral. Rio de Janeiro: Ateneu; 1985.

Mac Mahon B, Puch T. Epidemiology, principles and methods. Boston: Little Brown; 1970.

Maletta CHM. Epidemiologia e saúde pública. Rio de Janeiro: Atheneu; 1988.

Marcopito LF. Epidemiologia geral: exercícios para discussão. São Paulo: Atheneu; 1996.

Rouquayrol MZ. Epidemiologia e saúde. $\quad 3^{\mathrm{a}}$ ed. Rio de Janeiro: MEDSI; 1988.

Rouquayrol MZ. Epidemiologia e saúde. Rio de Janeiro: MEDSI; 1994. 
Seixas JC et al. Texto de apoio didático. São Paulo: Departamento de Prática de Saúde Pública- FSP/USP, 1991. [Documento interno]

Silva GR. Origens da medicina preventiva como disciplina de ensino médico. Rev Hosp Clin Fac Med: 28: 91-96, 1973.

Sounis E. Epidemiologia. Rio de Janeiro: Atheneu; 1985. 2v.

Vaugham JP, Morrow RH. Epidemiologia para os municípios. São Paulo: Hucitec; 1992.

10. FUNDAMENTOS DA EDUCAÇÃO AMBIENTAL

$(24 \mathrm{~h})$

Professora Responsável: Maria Cecilia Focesi Pelicioni

\section{Conteúdo Programático:}

- Conceitos de Educação Ambiental, Meio Ambiente. Princípios e características.

- Fundamentos históricos do Movimento Ambientalista e da Educação Ambiental.

- Estratégias de Atuação em Educação

Ambiental.

- Geração de eventos em quatro dimensões de mundo: indivíduos, grupos, sociedade e entorno. Abordagens educativas e configuração do campo de eventos

- Espaços atuais e potenciais de promoção da qualidade de vida: escola, trabalho, lazer, agências públicas, organizações comunitárias. Governo e sociedade civil

- Aplicação de modelos ecossistêmicos em diferentes projetos geradores de qualidade de vida.

\section{Bibliografia:}

Brasil. Lei n. 6.938 de 31 de agosto de 1981. Política Nacional do Meio Ambiente. Diário Oficial 1981; Brasília (DF). p.16509.

Brasil. Constituição da República Federativa do Brasil - 1988. Brasília (DF): Senado Federal; 1988.

Brasil. Lei n. 9.795 de 27 de abril de 1999. Política Nacional de Educação Ambiental. Diário Oficial 1999; (79): Brasília (DF).

[CNUMAD] Conferência das Nações Unidas sobre Meio Ambiente e Desenvolvimento. Agenda 21. Brasília (DF): Senado Federal, Subsecretaria de Edições Técnicas; 1997. $2^{a}$ ed.

Dias G F. Educação ambiental: princípios e práticas. São Paulo: Gaia; 1992.

Freire P. Pedagogia do oprimido. Rio de Janeiro: Paz e Terra, 1987. $17^{\mathrm{a}} \mathrm{ed}$.

Gadotti M. História das idéias pedagógicas. São Paulo: Ática, 2001. $8^{\mathrm{a}}$ ed.

Ginciene, E. R.; Pelicioni, A. F.; Benício, T. D. Projeto de Gestão e Educação Ambiental no Vale do Ribeira/SP. In: Diegues, A. C. e Viana, V. M. (orgs.) Comunidades Tradicionais e Manejo de Recursos Naturais na Mata Atlântica. São Paulo: Núcleo de Apoio à Pesquisa sobre Populações Humanas e Áreas Úmidas Brasileiras - NUPAUB/USP e Laboratório de Silvicultura Tropical da Escola Luís de Queirós - ESALQ/USP, 2000.

Houtart, F. \& Polet, F. (coord.) O outro Davos: mundialização de resistências e de lutas. São Paulo: Cortez, 2002.

[IBAMA] Instituto Brasileiro do Meio Ambiente e dos Recursos Naturais Renováveis. Educação Ambiental: as grandes orientações de Tbilisi. Brasília: IBAMA; 1997. 
Layrargues PP. A resolução de problemas ambientais locais deve ser um tema-gerador ou a atividade-fim da educação ambiental? In: Reigota M (organizador). Verde cotidiano: o meio ambiente em discussão. Rio de Janeiro: DP\&A, 1999. p. 131-148.

Mendes EV. Uma agenda para a saúde. $2^{a}$ ed. São Paulo: Hucitec; 1996.

[OPS] Organización Panamericana de la Salud. La administración estratégica: lineamientos para su desarrollo: los contenidos educacionales. Washington (DC); 1995. p.35-45.

Pelicioni AF. Metodologia participativa em capacitação de agentes indígenas de saúde. In: II Conferencia Latino-Americana de Promocion de la Salud y Educacion para la Salud; 1996, Santiago: Orla:Uipes, 1996. p.198-199.

Pelicioni, AF. Ambientalismo e Educação Ambiental. In: Educação ambiental na escola: um levantamento de percepções e práticas de estudantes de primeiro grau a respeito de meio ambiente e problemas ambientais. São Paulo; 1998. [Dissertação de Mestrado Faculdade de Saúde Pública da USP].

Pelicioni AF. Subsídios Teóricos e Práticos para a Educação Ambiental na Escola. Rev Debates Socioambientais $\mathrm{n}^{\circ} 10$ - jul/out 1998.

Pelicioni, AF. Fundamentos filosóficos e históricos da educação ambiental. O Biológico, v. 62, n.2, jul/dez, 2000.

Pelicioni AF. Educação Ambiental: limites e possibilidades de uma ação transformadora. São Paulo; 2002. [Tese de Doutorado - Faculdade de Saúde Pública da USP]

Pelicioni MCF. Qualidade de vida das mulheres trabalhadoras das creches conveniadas do bairro Bela Vista do Município de São Paulo. São Paulo; 1995. [Tese de Doutorado - Faculdade de Saúde Pública da USP].

Pelicioni MCF. Educação Ambiental, Qualidade de Vida e Sustentabilidade. Saúde e Sociedade 7 (2): 19-31, 1998.

Pelicioni MCF. As interrelações entre educação, saúde e meio ambiente. O Biológico, v.61, n.2, jul./dez, 1999.

Pelicioni MCF. Educação em saúde e educação ambiental - estratégias para construção da Escola Promotora da Saúde. São Paulo, 2000. [Tese de livre-docência Faculdade de Saúde Pública da USP]

Philippi Jr, A.; Pelicioni, MCF. (orgs.) Educação Ambiental - Desenvolvimento de Cursos e Projetos. São Paulo: Núcleo de Informação em Saúde Ambiental/ Faculdade de Saúde Pública/USP, 2000.

Secretaria do Meio Ambiente do Estado de São Paulo. Coordenadoria de Educação Ambiental. Educação ambiental e desenvolvimento: documentos oficiais. São Paulo, 1994. (Série Documentos)

Reigota M. O que é educação ambiental. São Paulo: Brasiliense; 1994. (Coleção Primeiros Passos)

Reigota M. Meio ambiente e representação social. São Paulo: Cortez; 1995.

Reigota, M. Ecologia, elites e intelligentsia na américa latina: um estudo de representações sociais. São Paulo: Annablume, 1999.

Reigota M.A floresta e a escola: por uma educação ambiental pós-moderna. São Paulo: Cortez; 1999.

Seoane, J. \& Taddei, E. (org.) Resistências mundiais: de Seattle a Porto Alegre.

Petrópolis, RJ: Vozes, 2001. 
Professor Responsável: Arlindo Philippi Jr.

\section{Conteúdo Programático:}

- A Questão Ambiental e sua abordagem. Aspectos Institucionais de Política e Gestão Ambiental.

- O Estado e a Sociedade no Processo de Formulação de Políticas Públicas. Conceitos, Políticas Compensatórias. Políticas Populacionais e o Meio Ambiente.

- O Setor de Produção e a Questão Ambiental. Modelos e Conceitos de Gestão. Cenário Político Econômico. O Papel da Educação Formal e Informal.

- Estudo de Caso: Programas de Controle Ambiental.

- Políticas de Meio Ambiente: Viabilidade de Implantação. Estruturação do Aparelho de Estado. Sistemas de Meio Ambiente.

- Educação Ambiental e Políticas Públicas. Gestão Urbana Auto Sustentada.

- O Papel dos Conselhos de Meio Ambiente nos Diferentes Níveis de Governo.

- O Componente Econômico na Formulação Legal da Área Ambiental.

- Desenvolvimento e Meio Ambiente: Estilos, Implicações, Variáveis, Rio 92.

- Iniciativas Governamentais para o Controle Ambiental: Mecanismos e Incentivos.

\section{Bibliografia:}

Abreu D. Sem ela, nada feito: uma abordagem da importância ambiental na implantação da ISO-14001.Salvador: Asset Negócios Corporativos; 1997.

Brasil. Constituição da República Federativa do Brasil. Brasília: Senado Federal; 1988.

Dias GF. Educação ambiental: princípios e práticas. São Paulo: Gaia; 1992.

Ferreira LC,Viola E. Incertezas de sustentabilidade na globalização. Campinas, São Paulo: Editora da Unicamp, 1996.

Ferreira LC. A questão ambiental - sustentabilidade e políticas públicas no Brasil. São Paulo: Boitempo Editorial, 1998.

Governo do Estado de São Paulo, Secretaria de Economia e Planejamento. O município no século XXI: Cenários e perspectivas. São Paulo: Fundação Prefeito Faria Lima, 1999.

Granziera MLM. Direito de águas: Disciplina jurídica das águas doces. São Paulo: Editora Atlas, 2001.

Henderson DR, Neves JC. Enciclopédia de Economia. Cascais, Portugal: Principia, Publicações Universitárias e Científicas; 2001.

Leff E. Ecologia, capital e cultura: racionalidade ambiental, democracia, participativa e desenvolvimento sustentável. Blumenau, Sta Catarina: Edifurb; 2000.

Leff E. Los problemas del conocimiento y la perpectiva ambiental del desarrollo. México, DF: Siglo Veintiuno Editores, SA de CV; 2000.

Ministério da Saúde. Plano nacional de saúde e ambiente no desenvolvimento sustentável: diretrizes para implementação. In: Conferência Pan-Americana sobre Saúde e Ambiente no Desenvolvimento Humano Sustentável; 1995 jul; Brasília (DF). Brasilia; 1995.

Moreira MS. Estratégia e Implantação do Sistema de Gestão Ambiental (modelo ISO 14000). Belo Horizonte: Editora de Desenvolvimento Gerencial, 2001. 
Muñoz HR. Intefaces da gestão de recursos hídricos - desafios da lei de águas de 1997. Brasília, DF: Secretaria de Recursos Hídricos; 2000.

Neder RT. Crise sócio ambiental - Estado \& sociedade civil no Brasil (1982-1998). São Paulo: Annablume: Fapesp, 2002.

Philippi Jr A, Alves AC, Romero MA, Bruna GC. Meio Ambiente, Direito e Cidadania. São Paulo: Universidade de São Paulo/FSP - Signus Editora; 2002.

Philippi Jr. A, Brunaci A, Andreoli CV, Moreira IVD, coordenadores. Brasil'92: perfil ambiental e estratégias. São Paulo: Secretaria de Estado do Meio Ambiente; 1992.

Philippi Jr. A, Coimbra A, Maglio I, Franco RM. Municípios e meio ambiente: perpectivas para a municipalização da gestão ambiental no Brasil. São Paulo: Associação Nacional de Municipios e Meio ambiente; 1999.

Philippi Jr. A, coordenador. Agenda 21 Local: compromisso do Município de São Paulo. São Paulo: Secretaria Municipal do Verde e do Meio Ambiente; 1996.

Philippi Jr. A, Elias EO, coordenadores. A questão ambiental urbana: cidade de São Paulo. São Paulo: Secretaria Municipal do Verde e do Meio Ambiente; 1993.

Philippi Jr. A, Pelicioni CF. Educação ambiental: desenvolvimento de cursos e projetos. São Paulo: Signus; 2000.

Philippi Jr. A, Tucci CEM, Hogan DJ, Navegantes R. Interdisciplinaridade em ciências ambientais. São Paulo: Signus; 2000.

Reigota M. Educação ambiental e representação social. São Paulo: Cortez; 1997.

Torres H, Costa H. População e meio ambiente - Debates e desafios. São Paulo: Editora Senac, 2000.

United Nations Centre For Regional Development. The context of decentralization reforms in Latin America. Nagoya; 1996. Local and Regional Development planning and management. (UNCRD Research Report Series, 18).

\section{DIREITO AMBIENTAL APLICADO}

\section{Professor Responsável: Daniel Fink}

\section{Conteúdo Programático:}

- Raízes do Direito Ambiental - O condicionamento econômico na formulação das leis municipais; Referências históricas e evolução das normas de proteção ambiental no ocidente e no Brasil; Tendências de evolução do Direito Ambiental- internacionalização e publicização do interesse no uso dos recursos ambientais.

- Enquadramento Ideológico do Direito Ambiental - A era industrial e a evolução do direito (dos direitos individuais aos interesses difusos);

- Princípios Gerais e Internacionais do Direito Ambiental - Evolução e aplicabilidade no Direito Nacional; Declarações de Estocolmo e do Rio de Janeiro.

- Conceito e Constitucionalidade do Direito Ambiental - Transdiciplinariedade do Direito Ambiental; A Constituição Federal e a Fundação Jurídica Ambiental; Definição e amplitude do bem jurídico ambiental; Titularidade e beneficiários do bem jurídico ambiental; A propriedade, a ordem econômica, os bens públicos, a tríplice responsabilidade pelo dano ambiental e as competências legislativa e funcional dos entes federados. 
- A Política Nacional do Meio Ambiente - Conceitos legais de meio ambiente, poluição e poluidor; O Sistema Nacional do Meio ambiente - SISNAMA: Conceito, estrutura e competências.

- Os Institutos da Avaliação de Impacto Ambiental e do Licenciamento Ambiental; Zoneamento Ambiental e Espaços Territoriais Especialmente Protegidos.

- Sanções Administrativas - Conceito de infração administrativa e responsabilidades; Competências, Tipos de Sanções; Processo Administrativo.

- Instrumentos de Tutela Jurisdicional do Meio Ambiente - Responsabilidade Civil e Criminal; Tutela Penal - Amplitude do agente, Tipificação dos delitos, Processo Penal, Tutela Civil, Ação Civil Pública e Ação Popular, Ações de Vizinhança.

\section{Bibliografia:}

Machado PAL . Direito Ambiental Brasileiro. $7^{0}$ ed. São Paulo:Malheiros; 1998.

Mukai T. Direito ambiental sistematizado. Rio de Janeiro: Forense Universitária; 1992.

Costa Jr PJ da. Direito Penal Ecológico. Rio de Janeiro: Forense Universitária; 1996.

Freitas GVP de. Crimes Contra a Natureza. $5^{0}$ ed. São Paulo: Revista dos Tribunais; 1995.

Benjamim AHV, coordenador. Dano Ambiental: Prevenção, Reparação e Repressão. São Paulo: Revista dos Tribunais; 1994.

Pedro AFP. Breves considerações sobre os conceitos tradicionais de uso da propriedade e direito de vizinhança face ao ordenamento ambiental: direito de agir pelas vias tadicionais. Rev Direito Amb (0): 131

Pedro AFP. Parâmetros Ideológicos da gestão dos Interesses difusos aplicados ao gerencia-mento ambiental: o SISNAMA. Rev Direito Amb (6): 71

Silva JÁ Direito ambiental constitucional. 20 ed. São Paulo: Malheiros; 1995.

Constituição Federal; Decreto - Lei n 25, de 30/11/37 Patrimônio Histórico Nacional

Lei no 4.717, de 29/6/65 Ação Popular

Lei $n^{\circ} 4.771$, de 15/09/65 Código Florestal

Lei n 5.197 , de 03/01/67 Proteção à Fauna

Decreto - Lei no 221, de 28/02/67 Proteção à Pesca

Decreto - Lei no 227, de 28/02/67 Código de Mineração

Lei no 6.543, de 17/10/77 Responsabilidade Civil e Criminal por Danos Nucleares

Lei $n^{\circ}$ 6.514, de 22/12/77 Segurança e Medicina do Trabalho

Lei no 6766 de 19/12/79 Parcelamento do Solo Urbano

Lei $n^{\circ} 6.803$, de 02/07/80 Zoneamento Industrial

Lei $n^{\circ}$ 6.938, de 31/08/81 Política Nacional do Meio Ambiente

Lei no 7.347, de 24/07/85 Disciplina a Ação Civil Pública

Lei $n^{\circ} 7.661$, de 16/05/88 Plano Nacional de Gerenciamento Costeiro

Lei $n^{\circ} 7.802$, de 11/07/89 Agrotóxicos

Lei $n^{\circ}$ 9.605, de 13/02/98 Lei de Crimes e Infrações Administrativas contra o Meio Ambiente 
Resolução CONAMA 1/86 EIA/RIMA

Resolução CONAMA 9/87 Audiências Públicas

Resolução CONAMA 6/88 Licenciamento de Resíduos Industriais Perigosos

Resolução CONAMA 5/89 Controle da Poluição do Ar PRONAR

Resolução CONAMA 1/90 Critérios e Padrões para Emissão de Ruídos Industriais

Resolução CONAMA 237/97 Licenciamento Ambiental

A. 18 
Professor Responsável: Marcelo de Andrade Roméro

\section{Conteúdo Programático:}

- O processo de Urbanização.

- O processo de Urbanização Brasileiro.

- Obras Urbanas: O Processo de Decisão.

- Recursos para as Obras Urbanas.

- Conservação de Energia na Cidade

- Saneamento e Drenagem.

\section{Bibliografia:}

Alexander C et al. The production of houses. New York: Oxford University Press; 1985.

Alexander $C$ et al. Urbanismo y participación: el caso de la Universidad de Oregón. Barcelona: Gili; 1976.

Alva EN. Participação e descentralização: um avanço democrático necessário. In: Prefeitura do Município de São Paulo. Comissão Econômica para a América Latina. Universidade das Nações Unidas. América Latiana: crise nas metrópoles. São Paulo; 1985. p. 59-64.

Arkes $\mathrm{H}$. The philosopher in the city: the moral dimensions of urban politics. Princeton: Princeton University Press; 1981.

Assis ES de et al. Experiência de planejamento participativo na urbanização de favelas de Belo Horizonte. In: Anais do $2^{\circ}$ SEDUR: Desenho Urbano. São Paulo: Pini; 1986. p. 63-293.

Cardoso RCL. Participação política e democracia. Novos Estudos CEBRAP 1990; 26 : 15-24.

Castells M. Cidade, democracia e socialismo. São Paulo: Paz e Terra; 1980.

Castells M. La question urbaine. Paris: Maspero; 1977.

Cavalcanti J. Recife: dividindo responsabilidades. In: Prefeitura do Município de São Paulo. Comissão Econômica para a América Latina. Universidade das Nações Unidas. América Latina: crise nas metrópoles. São Paulo; 1985. p. 103 -9.

Clark H, Manzo L. Community gardens: factors that influence participation. In: People's Needs/Planet Management Paths To Co-Existence. Washington: EDRA; 1988. p.57-61.

Dallari P. Participação no orçamento? In: Prefeitura do Município de São Paulo. Comissão Econômica para a América Latina. Universidade das Nações Unidas. América Latina: crise nas metrópoles. São Paulo; 1985. p 81.

De Angelis W. Participação ou cooptação? In: Prefeitura do Município de São Paulo. Comissão Econômica para a América Latina. Universidade das Nações Unidas. América Latina: crise nas metrópoles. São Paulo; 1985. p.79. 
Drucker PF. The practice of management. New York: Harper \& Row; 1954.

Fruet M. Curitiba discute com a comunidade. In: Prefeitura do Município de São Paulo. Comissão Econômica para a América Latina. Universidade das Nações Unidas. América Latina: crise nas metrópoles. São Paulo; 1985. p. 94.

Graciarena J. Urbanização e subdesenvolvimento. Rio de Janeiro: Zahar; 1979. Urbanização, estrutura de poder e participação; p. 166-189.

Kowarick L. O estado e a participação popular. In: Prefeitura do Município de São Paulo. Comissão Econômica para a América Latina. Universidade das Nações Unidas. América Latina: crise nas metrópoles. São Paulo; 1985. p.73 - 76.

Lojkine J. Le marxisme, l'état e la question urbaine. Paris: Presses Universitaires de France; 1977.

Marcus CC, Sarkissian W . Housing as if people mattered. Berkeley: University of California Press; 1986.

Padrés F. Participação ou anarquia? . In: Prefeitura do Município de São Paulo. Comissão Econômica para a América Latina. Universidade das Nações Unidas. América Latina: crise nas metrópoles. São Paulo; 1985. p. 80.

Sampaio MRA de. Heliópolis: o percurso de uma invasão. São Paulo; 1990. [Tese de Livre - Docência da FAU/USP]

Secretaria Especial da Reforma Administrativa da Prefeitura Municipal de São Paulo. Proposta de novo modelo organizacional da PMSP. São Paulo; 1991.

Sanoff H. Participatory design in focus. In: Architecture \& comportement/aArchitecture \& behaviour. 1988. p. 27-42.

Serra G. Urbanização e centralismo autoritário. São Paulo: Nobel/Edusp; 1991.

Tomic B. Participação e mobilização popular: o caso chileno. In: Prefeitura do Município de São Paulo. Comissão Econômica para a América Latina. Universidade das Nações Unidas. América Latina: crise nas metrópoles. São Paulo; 1985. p. 65 - 71.

Wates N, Knevitt C. Community architecture. London: Penguin; 1987.

Wilheim J. A pedagogia da participação. In: Prefeitura do Município de São Paulo. Comissão Econômica para a América Latina. Universidade das Nações Unidas. América Latina: crise nas metrópoles. São Paulo; 1985. p.78.

14. PLANEJAMENTO TERRITORIAL

Professor Responsável: Wilson Edson Jorge; Jorge Hagime Oseki

\section{Conteúdo Programático:}

- Temas Gerais da Disciplina.

- Estado e o Planejamento-Teorias do Estado

- Região e Planejamento - O Caso Brasileiro

- Cidade e Natureza - Produção capitalista (e estatista) do espaço.

- Planejamento Ambiental.

- Planejamento e Urbanismo.

- Modelos Participativos de Planejamento

- Laboratório - Avaliação dos Trabalhos 
- Seminários.

\section{Bibliografia:}

Arrighi G. O longo século XX. São Paulo: Editora UNESP; 1994.

Boron AA. Estado capitalismo e democracia na América Latina. São Paulo: Paz e Terra; 1995.

Campos Filho CM. Cidades brasileiras: seu controle ou o caos. São Paulo: Nobel; 1989.

Engels F. A questão da habitação. São Paulo: Acadêmica; 1988.

Giannotti JA. A sociabilidade travada. Novos Estudos CEBRAP 1990 (28).

Jorge WE. O conceito de estado - síntese das teorias formuladas por Machiavel, Lenin, Gramsci e Weber. Sinopses FAUUSP 1985 (8): 231.

Jorge WE. A política nacional de saneamento pós 64. São Paulo, 1987. [Tese de Doutorado - FAU/USP].

Ministério das Relações Exteriores/PNUD. Habitação e as políticas urbana, fundiária e ambiental. Brasília, 1995.

Oliveira F. O estado e o urbano no Brasil. Espaço \& Debates 1982; (6): 38.

Santos M. Metrópole corporativa fragmentada: o caso de São Paulo. São Paulo: Nobel; 1990.

Zahn CE. A importância da integração e da gestão regional no processo governamental. In: FUNDAP. A nova organização regional do Estado de São Paulo: subsídios para um novo modelo de gestão. São Paulo; 1991.

15. GESTÃO DE ÁREAS ESPECIAIS

Professoras Responsáveis: Heliana Comin Vargas

\section{Conteúdo Programático:}

- Qualidade ambiental urbana.

- Planejamento estratégico novos instrumentos de gestão ambiental urbana: comunicação.

- Negociação I. Novos instrumentos de gestão ambiental urbana - Negociação II. Conceitos: Conservação, Recuperação, Renovação.

- Re-Habilitação e Revitalização Urbana.

- Produção do espaço urbano.

- Recuperação de Áreas Degradadas por Mineração.

- Avaliação do passivo ambiental.

- Habitação e ambiente.

- Avaliação/Seminário.

\section{Bibliografia:}

Abreu S. Recursos minerais do Brasil. $2^{a}$ ed. Rio de Janeiro: Edgard Blücher/Edusp; 1973. 2v.

Almeida CM, Bruna GC. Conceitos de preservação, recuperação, renovação, reabilitação e revitalização ambiental urbana: principais exemplos e técnicas 
utilizadas. São Paulo: FAU/FSP-USP, 1996. (Roteiro geral de disciplina sobre gestão de áreas especiais).

Associação Brasileira de Normas Técnicas. Degradação do solo - terminologia - NBR 10.703. Rio de Janeiro; 1989.

Associação Brasileira de Normas Técnicas. Coletânea de normas de mineração e meio ambiente. Rio de Janeiro: ABNT/CVRD, 1993.

Barth RC. Avaliação da reabilitação de áreas mineradas no Brasil. Brasil Mineral 1989; 60-72. (Edição especial: meio ambiente).

Cairns $\mathrm{Jr}$ J.Restoration, reclamation and regeneration of degraded or destroyed ecosystems. In: Soulé, M E, organizador. Conservation biology. Sunderland: Sinauer; 1986. p. 465-484.

Comune $\mathrm{AE}$. Contabilização econômica do meio ambiente: uma visão geral. In: Secretaria do Meio Ambiente. Contabilização econômica do meio ambiente: elementos metodológicos e ensaio de aplicação no Estado de São Paulo. São Paulo; 1992. p. 13-27. (Série Seminários e Debates).

Dietrich NL . European rehabilitation projects reflect cultural and regional diversity. Rock Products 1990; 93 (2): 45-47.

Down CG, Stocks J. Environmental impact of mining. New York: John Wiley; 1977.

Empresa Metropolitana de Planejamento da Grande São Paulo. Implantação do plano diretor de mineração para a RMSP - Fase 7. São Paulo: SNM/Emplasa; 1989.

Environmental Protection Agency. Rehabilitation and revegetation. Australia; 1995.. (Serie on Best Practice Environmental Management in Mining).

Fundação SEADE. Perfil municipal 1980/91: Região Metropolitana de São Paulo. São Paulo; 1993. v.1

Fundação IBGE. Anuário estatístico do Brasil. Rio de Janeiro, 1994. v. 54, p. 1.1-8.32.

Instituto de Pesquisas Tecnológicas do Estado de São Paulo. Programa de Atualização Tecnológica Industrial- PATI : estudos setoriais - mineração. São Paulo; 1993. (IPTRelatório, 30.503).

Knecht T. Ocorrências minerais do Estado de São Paulo. São Paulo: Instituto Geográfico e Geológico/Secretaria da Agricultura; 1950. v. 1.

Região Metropolitana de São Paulo já é a $2^{\mathrm{a}}$ maior do mundo, revela ONU. O Estado de São Paulo, 1993 abr 28.

Sánchez L E. Projetos de recuperação: usos futuros e a relação com a comunidade. In: Anais do $1^{\circ}$ Encontro de Mineração no Município de São Paulo, 1994. São Paulo: SAR/PMSP/Epusp, 1995. v. 1, p. 53-83.

Santos M. A urbanização brasileira. São Paulo: Hucitec; 1993.

Secretaria de Estado dos Negócios Metropolitanos. Empresa de Planejamento da Grande São Paulo. Manual técnico para empreendimentos minerais na PMSP. São Paulo: SNM/Emplasa, 1982. 2v.

Toy TJ, Hadley RF. Geomophology and reclamation of disturbed lands. London: Academic Press; 1987.

União Internacional para a Conservação da Natureza. Programa das Nações Unidas para o Meio Ambiente. Fundo Mundial para a Natureza. Cuidando do planeta terra. São Paulo; 1991.

Valverde FM, Moraes RO, Kulaif $\mathrm{Y}$. Atividade mineral: potencialidade e explotação atual. In: Anais do $1^{\circ}$ Seminário sobre Problemas Geológicos e Geotécnicos na Região 
Metropolitana de São Paulo; 1992; São Paulo, Brasil. São Paulo: Abas/ABGE/SBG-SP; 1992. p. 57-62.

Vargas M. Metodologia da pesquisa tecnológica. Rio de Janeiro: Globo; 1985.

Willians DD, Bugin A, Reis JLB, coordenadores. Manual de recuperação de áreas degradadas pela mineração: técnicas de revegetação. Brasília: Ibama; 1990.

16. AVALIAÇÃO DE IMPACTO AMBIENTAL Professores Responsáveis: Helena Ribeiro; Carlos Celso do Amaral e Silva

\section{Conteúdo Programático:}

- Origens e objetivos da Avaliação de Impactos Ambientais. Avaliação de Impactos Ambientais no contexto da Política Ambiental Brasileira. Etapas da elaboração de um Estudo de Impacto Ambiental.

- Conceitos básicos: Poluição, Degradação Ambiental, Recuperação Ambiental. Qualidade Ambiental, Impacto Ambiental. Avaliação de Riscos e Processos de Avaliação de Impactos.

- Conceitos Básicos de Qualidade Ambiental Urbana. Impactos no Ambiente Construído.

- Impactos Territoriais Urbanos: Adensamento, Substituição de Usos, Congestionamento dos serviços e Equipamentos Sociais. Evolução dos instrumentos de controle: Relatório de Impacto de Vizinhança (RIMIZ).

- Avaliação dos Impactos Sócio-Econômicos.

- Avaliação dos Impactos sobre o Meio Físico e Biológico.

- Procedimentos da AIA: Seleção de Projetos, Planos e Ações. Elaboração de Termos de Referência. Conteúdo de um RIMA. Exame de um Estudo de Impacto Ambiental (EIA/RIMA): Os participantes e seus diferentes papéis.

\section{Bibliografia:}

Muller - Plantenberg C, Ab'Saber NA. Previsão de impactos. São Paulo:EDUSP; 1994.

Academie Internationale de Lènvironnnement. Étude d'imapct environnemental. Genève; 1994.

Secretaria do Meio Ambiente. Manual de orientação EIA/RIMA. São Paulo; 1992.

International Association for Imapct Assesament. Avaliação de impactos. 1994.

Juchen PA. Manual de avaliação de impactos ambientais. Instituto Ambiental do Paraná/GTZ; 1993.

Tommassi LR. Estudo de impacto ambiental. São Paulo: CETESB/Terragraph; 1994.

Wetzefeld $\mathrm{H}$. Manual básico sobre avaluación del impacto en el ambiente y la salud. México: Centro Panamericano de Ecologia Humana y Salud; 1996.

Oliveira RF. Análise de impacto ambiental: conceitos e prática aos EISs de projetos urbanos no município de São Paulo. São Paulo; 2001. [Dissertação de Me4strado Faculdade de Saúde Pública da USP]. 


\section{Professores Responsáveis: Arlindo Philippi Jr e Alexandre de Oliveira Aguiar}

\section{Conteúdo Programático:}

- Sistemas de Referências: Normas Internacionais de Excelência em Gestão Ambiental. ISO 9000 e ISO 14000; paradigmas de gestão - A década de 90 e a era pós ISO 9000; distinção entre gestão ambiental pela ISO 9000 e pela ISO 14000; distinção entre auditoria do sistema de gestão e auditoria de conformidade legal; distinção entre gestão da qualidade e gestão do meio ambiente.

- Gestão da Qualidade. Análise do Contexto de Comunicação do processo de gestão da qualidade e seleção de Normas; o significado dos requisitos das Normas de Excelência; Aplicações práticas de auditoria ambiental pelos requisitos da ISO 14.000 em âmbito de empresa e de órgãos públicos.

- Gestão do Meio Ambiente. Análise do Contexto de Comunicação do processo de gestão da qualidade e seleção de Normas; o significado dos requisitos das Normas de Excelência; Aplicações práticas de auditoria ambiental pelos requisitos da ISO 14.000 em âmbito de empresa e de órgãos públicos.

- Hábitos e Técnicas de Comunicação e de Relacionamento do Auditor Ambiental. O perfil do auditor, fazedor de generalizações e o fazedor de distinções; treinamento de posturas para realizar uma auditoria; distinções: alinhamento, efetividade e integridade.

- Guias e Roteiros de trabalho para realização de Auditorias em Saúde, Segurança e Meio Ambiente. Fundamentos de auditoria: responsabilidade do auditor; procedimentos e protocolos de auditoria; entrevista, atividades chaves da auditoria, pré-auditoria, lista de verificação e questionários; atividade do auditor no ambiente da empresa ou órgão público; pós auditoria.

\section{Bibliografia:}

Berle G. O empreendedor do verde: oportunidade de negócios em que Você pode salvar a terra e ainda ganhar dinheiro. Trad G P Wiezel. São Paulo: Makron; McGraw Hills; 1992.

Bronfenbrenner U. A ecologia do desenvolvimento humano: experimentos naturais e planejados. Trad. MAV Veronese. Porto Alegre: Artes Médicas; 1996.

Davis $\mathrm{K}$ et al. Cidades: a urbanização da humanidade. Trad. J Reznik. $3^{\mathrm{a}}$ ed. São Paulo: Zahar; 1977.

Donaire D. Gestão ambiental na empresa São Paulo. Atlas; 1995.

Gutberlet J. Cubatão: desenvolvimento, exclusão social, degradação ambiental. São Paulo: EDUSP/FAPESP, 1996.

Jannuzzi G de M, Swisher JNP. Planejamento integrado de recursos energéticos: meio ambiente, conservação de energia e fontes renováveis. Campinas: Autores Associados; 1997.

Klebs JR, Davies ND. Introdução à ecologia comportamental. Trad. M Ramalho e C P Machado. São Paulo: Atheneu; 1966.

Morris D. O contrato animal. Trad. L Simonini. Rio de Janeiro: Record; 1997.

Mumford L. A cidade na história. Trad. N R. da Silva. $3^{a}$ ed. São Paulo: Martins Fontes; 1991. 
Schmidheiny S. Mudando o rumo; uma perspectiva empresarial global sobre desenvolvimento e meio ambiente. Trad. ML Rodrigues. Rio de Janeiro: Fundação Getúlio Vargas; 1992.

Singer P. Ética prática. Trad. JL Camargo. São Paulo: Martins Fontes; 1994. O meio ambiente;p. 279-304.

Sitte C. A construção das cidades segundo seus princípios artísticos. Trad. RF Henrique. São Paulo: Ática; 1992.

Thomas K. O homem e o mundo natural. Trad. JR Martins Filho. São Paulo: Companhia das Letras; 1988.

Tuan Yi-Fu. Espaço e lugar: a perspectiva da experiência. Trad. L de Oliveira. São Paulo: DIFEL; 1983.

Tuan Yi-Fu. Topofilia: um estudo da percepção, atitudes e valores do meio ambiente.

Trad. L de Oliveira. São Paulo: DIFEL; 1980.

\section{SEMINÁRIOS SOBRE GESTÃO AMBIENTAL}

Professores Responsáveis: Arlindo Philippi Jr; Marcelo de Andrade Romero; Cintia P. Salles

\section{Conteúdo Programático:}

- Análise e avaliação da gestão ambiental através de estudos de casos. Tais estudos deverão contemplar os fundamentos do controle ambiental, os aspectos sócio - político - culturais e as práticas de planejamento e gestão ambiental.

- Os seminários deverão ser estruturados a partir de grupos de trabalho em torno de estudos de caso relativos a projetos ambientais , envolvendo: habitação para população de baixa renda, uso e ocupação de fundos de vale, transporte urbano e áreas de proteção de mananciais, saneamento , recursos hídricos, entre outros.

- Os seminários serão estruturados para receberem a apresentação, discussão e avaliação das monografias de final de curso.

- As monografias de final de curso serão definidas em aula específica e serão de responsabilidade de grupos constituídos por no máximo 4 membros, com base em escolha de comum acordo entre os alunos e os professores responsáveis.

- Definidos os temas e respectivos grupos de trabalho, estes deverão atender ao estabelecido a seguir: 


\section{ÍNDICE DO PROJETO DE MONOGRAFIA}

- Os grupos de trabalho deverão apresentar Projeto de sua Monografia à Coordenação do curso.

- O projeto de monografia será submetido à apreciação da Comissão Examinadora, que indicará o professor orientador para cada grupo em função do tema selecionado.

- Sugestão de Índice do Projeto:

- Introdução

- Objetivo - o que se pretende conseguir, ou a que resultados a equipe pretende chegar com a execução da monografia.

- Metodologia - exposição da forma de encaminhamento da monografia.

- Cronograma

-Bibliografia Básica.

\section{APRESENTAÇÃO DO TRABALHO}

- Da Redação: Texto em espaço duplo, formato A4, normas gerais da Faculdade de Saúde Pública (capa, contracapa, folha de rosto, resumo, bibliografia). [Guia de Apresentação de teses]

- Da entrega:

A minuta da Monografia: deverá ser entregue ao orientador com no mínimo uma semana antes da apresentação à banca.

Sumário executivo da Monografia: elaborado em 5 páginas, deverá ser entregue à secretaria executiva em 4 vias, com a antecedência de 1 semana da data de apresentação.

A Monografia devidamente encadernada em forma de brochura, deverá ser encaminhada em 1 via acompanhada do correspondente disquete, identificando o título da monografia e a equipe, à Coordenação do Curso, contendo o de acordo do orientador.

A capa deverá conter: Universidade de São Paulo; Faculdade de Saúde Pública; Faculdade de Arquitetura e Urbanismo; Núcleo de Informações em Saúde Ambiental; nome do curso; título da monografia; nome da cidade; ano; nome do orientador.

A lombada deverá conter as seguintes informações: FSP; USP; título da monografia; ano.

\section{Da Exposição:}

Apresentação dos trabalhos por meio de seminários, pelos integrantes das equipes, com 15 minutos de duração, seguidos da correspondente argüição. A apresentação deve ser preparada com padrão profissional, utilizando-se recursos necessários, tais como: fotos, slides, transparências, mapas, etc.

\section{INFORMAÇÕES GERAIS}

- O desenvolvimento dos projetos terá o acompanhamento da Coordenação.

- No decorrer da elaboração da Monografia, os grupos poderão solicitar atendimento de seu professor orientador.

- As apresentações das monografias serão realizadas em Seminário, perante Comissão Examinadora constituída especificamente para a Avaliação.

\section{Bibliografia:}


Cuenca AMB; Noronha DP; Ferraz MLEF; Andrade MTD. Guia de Apresentação de Teses. Universidade de São Paulo. São Paulo: A Biblioteca, 1998.

Coimbra JAA. O outro lado do Maio Ambiente. São Paulo: CETESB, 1985.

Henderson DR, Neves JC. Enciclopédia de Economia. Cascais, Portugal: Principia, Publicações Universitárias e Científicas; 2001.

Leff E. Epistemologia Ambiental. São Paulo: Cortez Editora, 2001.

Philippi Jr A; Tucci CEM; Hogan DJ, Navegantes R. Interdisciplinaridade em Ciências Ambientais. São Paulo: Signus Ed. 2001.

Rebouças AC, Braga B, Tundisi JG. Águas doces no Brasil: capital ecológico, uso e conservação. São Paulo: Escrituras Editora, 1999.

Secretaria Municipal de Cultura da PMSP. Guarapiranga: recuperação urbana e ambiental no Município de São Paulo. São Paulo: M. Carrilho Arquitetos, 2000.

Tucci CEM; Marques DMLM. Avaliação e controle da drenagem urbana.Porto Alegre: Ed. Universidade?UFRGS, 2000. 
ANEXO 2

\section{MODELO DE QUESTIONÁRIO DE AVALIAÇÃO SEMESTRAL DO CURSO}




\section{QUESTIONÁRIO DE AVALIAÇÃO DO SEMESTRE}

O presente questionário é um instrumento de aprimoramento do Curso e desta forma, suas opiniões sobre as questões a seguir, são de suma importância para a Coordenação dos Cursos de Especialização do NISAM - USP.

ATENÇÃO : Avalie cada item do questionário, estabelecendo uma nota e variando de 0 a 10 para cada uma das questões.

\section{A - ASPECTOS GERAIS DO CURSO}

1. Objetivos alcançados

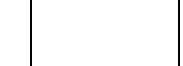

2. Conteúdo Programático

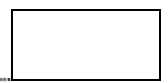

3. Distribuição da carga horária

4. Utilização de recursos áudio-visuais na explanação do conteúdo

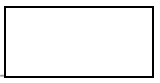

5. O material didático como complementação das informações dadas pelos professores

6. As referências bibliográficas indicadas como apoio ao conteúdo didático

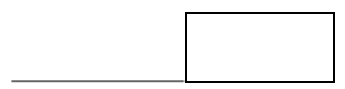

7. Forma de avaliação adotada no Curso

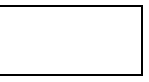

8. Grau de expectativa atendido pelo Curso

9. Das informações fornecidas durante o Curso, qual foi o percentual de novos conhecimentos trazidos para você?

10. Dê uma nota ao Curso 


\section{B - DOS DOCENTES}

ATENÇÃO: Avalie o quadro Docente do Curso com relação às questões abaixo, estabelecendo uma nota e variando de 0 a 10 para cada uma das questões abaixo:

11. Métodos e técnicas utilizados

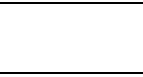

12. Clareza de explicações

13. Atendimento ao programa fornecido
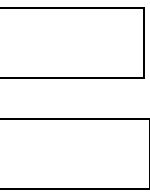

\section{C - DA CLASSE}

14. Desempenho da classe durante o Curso

15. Integração da classe durante o Curso

16. O seu próprio desempenho durante o Curso
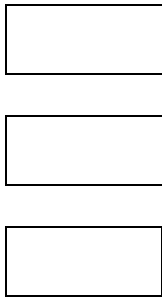

Comentários sobre o Curso e/ou sobre os professores 


\section{ANEXO 3}

\section{MODELO DO QUESTIONÁRIO DE AVALIAÇÃO DE DISCIPLINA}


UNIVERSIDADE DE SÃO PAULO

FACULDADE DE SAÚDE PÚBLICA

FACULDADE DE ARQUITETURA E URBANISMO

NÚCLEO DE INFORMAÇÕES EM SAÚDE AMBIENTAL

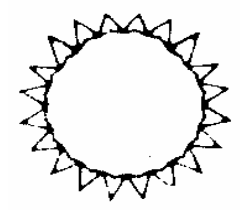

CURSO PÓS-GRADUAÇÃO LATO SENSU - ESPECIALIZAÇÃO EM

GESTÃO AMBIENTAL

\section{QUESTIONÁRIO DE AVALIAÇÃO}

\section{Disciplina:}

\section{Professor Responsável:}

O presente questionário é um instrumento de aprimoramento de Disciplinas e Cursos e desta forma, suas opiniões sobre as questões a seguir, são de suma importância para a Coordenação dos Cursos de Especialização do NISAM - USP.

ATENÇÃO : Avalie cada item do questionário, estabelecendo uma nota e variando de 0 a 10 para cada uma das questões.

\section{A - ASPECTOS GERAIS DA DISCIPLINA}

1. Objetivos alcançados

2. Conteúdo Programático

3. Distribuição da carga horária

4. Utilização de recursos áudio-visuais na explanação do conteúdo
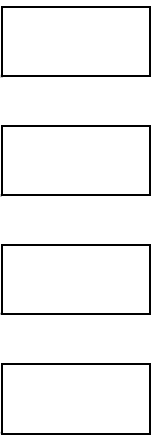

5. O material didático como complementação das informações dadas pelos professores

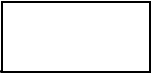

6. As referências bibliográficas indicadas como apoio ao conteúdo didático

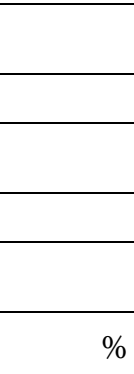

9. Das informações fornecidas durante o Curso, qual foi o percentual de novos 
conhecimentos trazidos para você?

\section{B - DOS DOCENTES}

ATENÇÃO: Avalie cada um dos Docentes relacionados nos quadros a seguir

\begin{tabular}{|l|}
\hline \multicolumn{1}{|c|}{ Docente } \\
\hline 1. \\
\hline 2. \\
\hline 3. \\
\hline 4. \\
\hline 5. \\
\hline
\end{tabular}

\section{Docente 1 Docente 2 Docente $3 \quad$ Docente 4}

10. Métodos utilizados
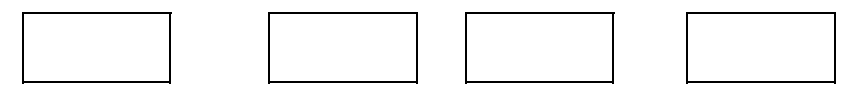

11. Clareza de explicações
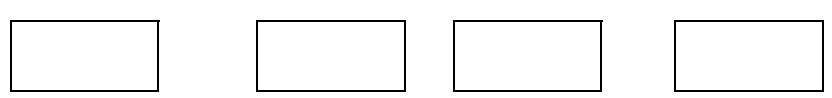

12. Atendimento ao programa fornecido
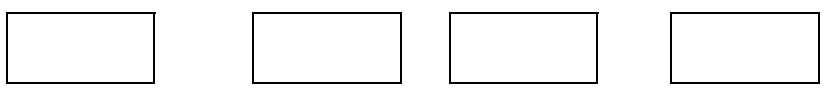

\section{C - DA CLASSE}

13. Desempenho da classe durante a Disciplina

14. Integração da classe durante a Disciplina

15. O seu próprio desempenho durante a Disciplina

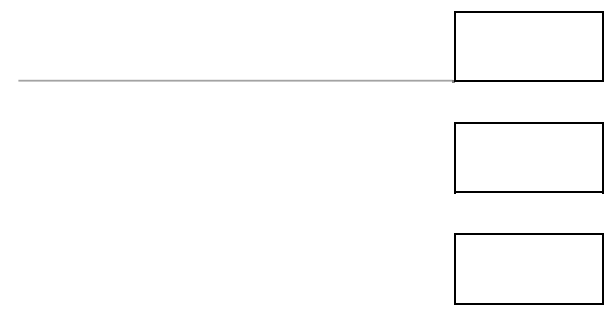

Espaço livre para sugestões e/ou apreciações complementares 


\section{ANEXO 4}

\section{PLANILHA COM OS RESULTADOS DA TABULAÇÃO DE DADOS DE DISCIPLINA DO CURSO}




\section{CEGA 13}

DISCIPLINA: DAP

NISAM - FSP - FAU - USP

\begin{tabular}{|c|c|c|c|c|c|c|c|c|c|c|c|}
\hline Alunos & Objetivos & Conteúdo & Dist.C.H. & Recur. A.V. & Mat.Didat. & Ref.Biblio. & Avaliação & Expectativa & Conh.novos & MT-Docente 1 & MT-Docente 2 \\
\hline 1 & 8 & 8 & 7 & 7 & 7 & 7 & 8 & 8 & $75 \%$ & 8 & 7 \\
\hline 2 & 9 & 8 & 9 & 8 & 8 & 9 & 9 & 8 & $85 \%$ & 10 & 10 \\
\hline 3 & 8 & 8 & 8 & 8 & 8 & 8 & 8 & 8 & $80 \%$ & 8 & 8 \\
\hline 4 & 10 & 10 & 10 & 10 & 10 & 10 & 10 & 10 & $100 \%$ & 10 & 10 \\
\hline 5 & 10 & 9 & 9 & 8 & 8 & 8 & 10 & 9 & $90 \%$ & 9 & 8 \\
\hline 6 & 9 & 9 & 8 & 9 & 9 & 8,5 & 9 & 9 & $9000 \%$ & 9,5 & 9,5 \\
\hline 7 & 10 & 10 & 10 & 10 & 10 & 10 & 10 & 10 & $100 \%$ & 10 & - \\
\hline 8 & 7 & 6 & 7 & 9 & 9 & 7 & 9 & 7 & $90 \%$ & 9 & 9 \\
\hline 9 & 10 & 10 & 10 & 10 & 10 & 10 & 10 & 10 & $100 \%$ & 10 & - \\
\hline 10 & 8 & 8 & 7 & 7 & 7 & 6 & 8 & 8 & - & 7 & 7 \\
\hline 11 & 8 & 8 & 8 & 7 & 7 & 7 & 9 & 8 & - & 7 & 8 \\
\hline 12 & 7 & 7 & 6 & 5 & 4 & 5 & 10 & 7 & $80 \%$ & 10 & 7 \\
\hline 13 & 6 & 7 & 7 & 4 & 4 & - & 10 & 5 & $50 \%$ & 7 & 5 \\
\hline 14 & 8 & 5 & 8 & - & - & - & 8 & 5 & $50 \%$ & 8 & 6 \\
\hline & Objetivos & Conteúdo & Dist.C.H. & Recur. A.V. & Mat.Didat. & Ref.Biblio. & Avaliação & Expectativa & Conh.novos & MT-Docente 1 & MT-Docente 2 \\
\hline MÉDIA & 8,43 & 8,07 & 8,14 & 7,85 & 7,77 & 7,96 & 9,14 & 8,00 & 8,25 & 8,75 & 7,88 \\
\hline MODA & 8,00 & 8,00 & 7,00 & 7,00 & 7,00 & 7,00 & 10,00 & 8,00 & 1,00 & 10,00 & 7,00 \\
\hline D.P. & 1,28 & 1,49 & 1,29 & 1,86 & 2,01 & 1,63 & 0,86 & 1,62 & 25,75 & 1,22 & 1,57 \\
\hline & & & & & & & & & & Questão 17 & Questão 17 \\
\hline MT-Docente 3 & EX-Docente & EX-Docente 2 & EX-Docente & PG-Docente 1 & PG-Docente & PG-Docente & ミDes.classe & Integr. Classe & Desemn.pes & Atua na área? & Atua na área? \\
\hline 7 & 8 & 8 & 9 & 7 & 7 & 7 & 8 & 8 & 8 & 1 & - \\
\hline 10 & 10 & 10 & 10 & 10 & 10 & 10 & 8 & 7 & 8 & - & - \\
\hline 6 & 8 & 8 & 6 & 8 & 8 & 7 & 8 & 7 & 7 & - & - \\
\hline 10 & 10 & 10 & 10 & 10 & 10 & 10 & 10 & 10 & 10 & - & 1 \\
\hline 10 & 9 & 9 & 9 & 9 & 8 & 9 & 8 & 8 & 8 & - & 1 \\
\hline 8 & 9,5 & 9,5 & 9 & 9 & 9 & 9 & 9 & 8,5 & 9 & 1 & - \\
\hline - & 10 & - & - & 10 & - & - & 8 & 7 & 8 & 1 & - \\
\hline 7 & 8 & 9 & 8 & 6 & 9 & 9 & 9 & 9 & 10 & - & - \\
\hline - & 10 & - & - & 10 & - & - & 9 & 10 & 10 & 1 & - \\
\hline 7 & 8 & 8 & 8 & 8 & 8 & 9 & 7 & 7 & 6 & 1 & - \\
\hline 9 & 8 & 8 & 9 & 8 & 8 & 9 & 7 & 7 & 7 & 1 & - \\
\hline 8 & 10 & 6 & 6 & 10 & 7 & 8 & 8 & 9 & 7 & 1 & - \\
\hline 5 & 7 & 5 & 5 & 7 & 5 & 7 & 7 & 7 & 5 & - & 1 \\
\hline 5 & 8 & 8 & 5 & 8 & 8 & 8 & 8 & 8 & 8 & 1 & - \\
\hline MT-Docente 3 & EX-Docente & EX-Docente 2 & EX-Docente & PG-Docente 1 & PG-Docente & PG-Docente & ¿Des.classe & Integr. Classe & Desemn.pes & Atua na área? & Atua na área? \\
\hline 7,67 & 8,82 & 8,21 & 7,83 & 8,57 & 8,08 & 8,50 & 8,14 & 8,04 & 7,93 & sim & não \\
\hline 7,00 & 8,00 & 8,00 & 9,00 & 10,00 & 8,00 & 9,00 & 8,00 & 7,00 & 8,00 & 8 & 3 \\
\hline 1,83 & 1,07 & 1,50 & 1,85 & 1,34 & 1,38 & 1,09 & 0,86 & 1,12 & 1,49 & - & - \\
\hline
\end{tabular}


ANEXO 5

\section{ROTEIRO DE ENTREVISTA FINAL APLICADO NESTA PESQUISA}


ROTEIRO DE ENTREVISTA

\section{O IMPACTO DA CAPACITAÇÃO EM GESTÃO AMBIENTAL}

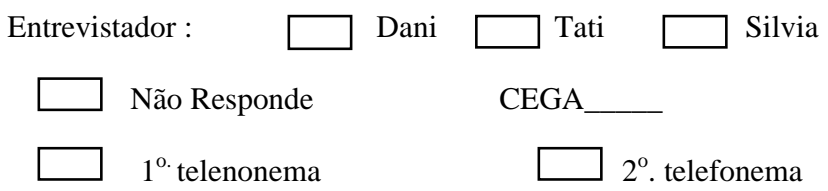

1. Trabalha na área no momento?
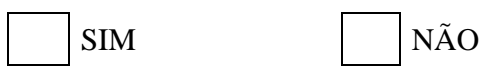

Já trabalhei

1.1 Se sim, onde?

$\square$ Público $\square$ Privado $\square$ ONG $\square$ Outro:

Qual:

1.1.1 Nome da empresa

1.1.2 Localização/cidade

1.1.3 Cargo ocupado

1.2 Após a conclusão do CEGA, avalie se a sua forma de pensar:

$\square$ Não mudou $\square$ Mudou pouco $\square$ Mudou muito

1.3 Após a conclusão do CEGA, avalie a sua atuação no local de trabalho:

$\square$ Não mudou $\square$ Mudou pouco $\square$ Mudou muito

1.4 Você acha que sua especialização em Gestão Ambiental contribuiu para a ascensão profissional na sua carreira?

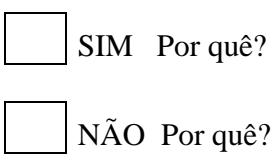

1.5 Na sua opinião, para a sua instituição, qual foi a conseqüência de tê-lo como profissional capacitado em Gestão Ambiental?

Houve expansão de atividades do setor ambiental na instituição

Houve aumento de funcionários no setor

Houve a criação de um setor ambiental que não existia

Houve a busca por algum tipo de certificação/ou cumprimento de legislação ambiental

Outros. Quais ?

A. 37 
1.6 Após o CEGA, você levou os seus conhecimentos para outras pessoas?

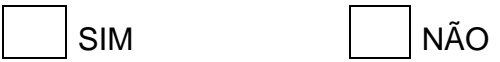

1.6.1 Se sim:

Como docente na sua cidade

Como docente fora da sua cidade

Como palestrante

Como assessor ou consultor

Outro(s) Qual/Quais?

Quantas pessoas estiveram envolvidas?

1.6.2. Se não, por que?

2. No atual estágio de sua carreira, que nota você daria ao conhecimento obtido no CEGA?

De 1 a 10

\subsection{Por que?}

3. Em que áreas listadas você atuou ou está atuando?

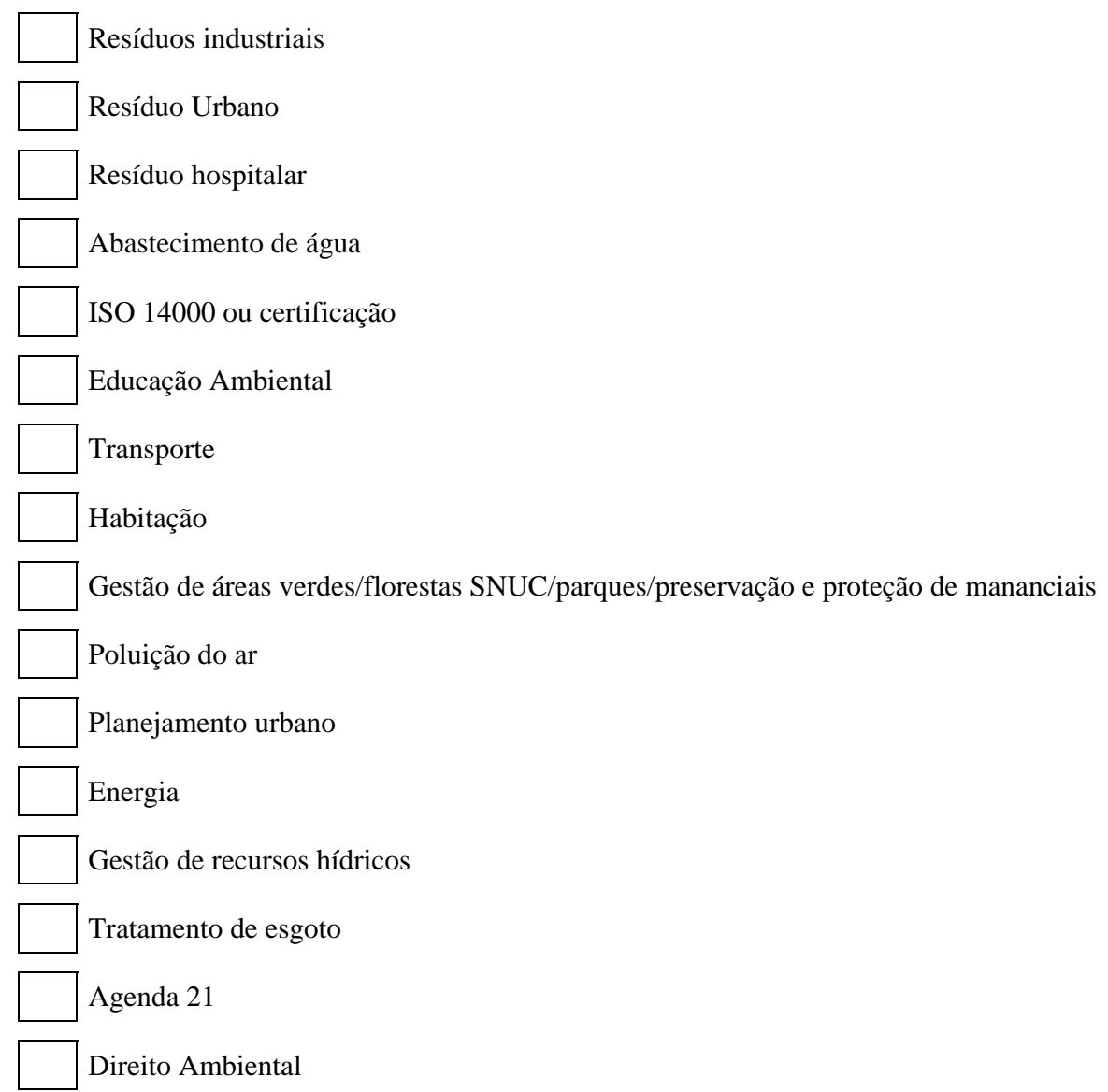


4. Avaliando o curso CEGA hoje, que tipo de conteúdo você acharia interessante ser aprofundado?

5. Avaliando o curso CEGA hoje, que tipo de conteúdo você acharia interessante ser adicionado?

Muito obrigado por sua atenção

A. 39 


\section{ANEXO 6}

\section{DADOS CADASTRAIS DOS ALUNOS}

(CEGA 1 - CEGA 13) 


\section{CEGA-1 - Identificação dos Alunos}

\begin{tabular}{|c|c|c|c|c|c|c|}
\hline & $\begin{array}{c}\text { Gênero } \\
\text { M/F }\end{array}$ & $\begin{array}{l}\text { Formação } \\
\text { (1) }\end{array}$ & $\begin{array}{c}\text { Ano de } \\
\text { conclusão/ } \\
\text { graduação }\end{array}$ & $\begin{array}{l}\text { Local de } \\
\text { atuação }\end{array}$ & $\begin{array}{c}\text { Trabalha na } \\
\text { área - S/N } \\
\text { (2) }\end{array}$ & $\begin{array}{l}\text { Setor } \\
\text { Pu/Pr/ } \\
\text { ONG }\end{array}$ \\
\hline 1 & $M$ & Eng. Mec. & - & São Paulo & $\mathrm{s}$ & $\mathrm{Pu}$ \\
\hline 2 & $F$ & Eng. Agr & $19-94$ & São Paulo & $\mathrm{S}$ & $\mathrm{Pu}$ \\
\hline 3 & $M$ & Eng. Civil & - & São Paulo & $\mathrm{S}$ & $\mathrm{Pu}$ \\
\hline 4 & $M$ & Arquiteto & 1983 & São Paulo & $\mathrm{S}$ & $\mathrm{Pu}$ \\
\hline 5 & $\mathrm{M}$ & Economia & - & São Paulo & $\mathrm{S}$ & $\mathrm{Pu}$ \\
\hline 6 & $\mathrm{M}$ & Eng. Civil & - & São Paulo & $\mathrm{S}$ & $\mathrm{Pu}$ \\
\hline 7 & $\mathrm{~F}$ & Arquiteta & - & São Paulo & - & $\mathrm{Pu}$ \\
\hline 8 & $\mathrm{~F}$ & Química & - & São Paulo & $\mathrm{S}$ & $\mathrm{Pu}$ \\
\hline 9 & $\mathrm{~F}$ & Direito & - & São Paulo & $\mathrm{S}$ & $\mathrm{Pu}$ \\
\hline 10 & $\mathrm{~F}$ & Arquiteta & 1982 & São Paulo & $\mathrm{S}$ & $\mathrm{Pu}$ \\
\hline 11 & $\mathrm{~F}$ & Arquiteta & 1987 & São Paulo & $\mathrm{S}$ & $\mathrm{Pu}$ \\
\hline 12 & $\mathrm{~F}$ & Arquitetura & 1978 & São Paulo & $\mathrm{S}$ & $\mathrm{Pu}$ \\
\hline 13 & $\mathrm{~F}$ & Contabilidade & 1978 & São Paulo & $\mathrm{S}$ & $\mathrm{Pu}$ \\
\hline 14 & $M$ & Eng. Civil & 1976 & São Paulo & $\mathrm{S}$ & $\mathrm{Pu}$ \\
\hline 15 & $\mathrm{~F}$ & Arquitetura & 1962 & São Paulo & $\mathrm{S}$ & $\mathrm{Pu}$ \\
\hline 16 & M & Arquiteto & 1973 & São Paulo & $\mathrm{S}$ & $\mathrm{Pu}$ \\
\hline 17 & $M$ & Arquiteto & 1982 & São Paulo & $\mathrm{S}$ & $\mathrm{Pu}$ \\
\hline 18 & $F$ & $\begin{array}{l}\text { Ciências } \\
\text { Jurídicas }\end{array}$ & 1978 & São Paulo & $\mathrm{N}$ & $\mathrm{Pu}$ \\
\hline 19 & M & Arquitetura & 1982 & São Paulo & $\mathrm{S}$ & $\mathrm{Pu}$ \\
\hline 20 & $\mathrm{~F}$ & Serviço Social & 1974 & São Paulo & $\mathrm{S}$ & $\mathrm{Pu}$ \\
\hline 21 & $\mathrm{M}$ & Geólogo & 1984 & 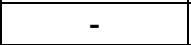 & - & \\
\hline 22 & M & Administração & 1977 & São Paulo & $\mathrm{S}$ & $\mathrm{Pu}$ \\
\hline 23 & $M$ & Administração & - & São Paulo & $\mathrm{S}$ & $\mathrm{Pu}$ \\
\hline 24 & $M$ & Eng. Químico & 1991 & São Paulo & $\mathrm{S}$ & $\mathrm{Pu}$ \\
\hline 25 & $\mathrm{~F}$ & Arquitetura & 1977 & São Paulo & $\mathrm{S}$ & $\mathrm{Pu}$ \\
\hline 26 & $M$ & Eng. Civil & 1960 & São Paulo & $\mathrm{S}$ & $\mathrm{Pu}$ \\
\hline 27 & $\mathrm{~F}$ & Pedagogia & 1989 & São Paulo & $\mathrm{S}$ & $\mathrm{Pu}$ \\
\hline 28 & $\mathrm{~F}$ & $\begin{array}{c}\text { Ciências Sociais } \\
\text { /Jornalismo }\end{array}$ & 1993/1985 & São Paulo & $\mathrm{S}$ & $\mathrm{Pu}$ \\
\hline 29 & $M$ & Eng. Civil & 1983 & São Paulo & $\mathrm{S}$ & $\mathrm{Pu}$ \\
\hline 30 & M & Eng. Mec. & - & São Paulo & $\mathrm{S}$ & $\mathrm{Pu}$ \\
\hline 31 & $M$ & Geógrafo & - & São Paulo & $\mathrm{S}$ & $\mathrm{Pu}$ \\
\hline
\end{tabular}

Legenda: M-masculino; F-feminino; S-sim; N-não; Pv-Privado; Pu-Público; ONG organização não governamental; CEGA- Curso de Especialização em Gestão Ambiental 


\section{CEGA-2 - Identificação dos Alunos}

\begin{tabular}{|c|c|c|c|c|c|c|}
\hline & $\begin{array}{l}\text { Gênero } \\
\text { M/F }\end{array}$ & Formação & $\begin{array}{c}\text { Ano de } \\
\text { conclusão/ } \\
\text { graduação }\end{array}$ & $\begin{array}{l}\text { Local de } \\
\text { atuação }\end{array}$ & $\begin{array}{l}\text { Trabalha na } \\
\text { área - S/N }\end{array}$ & $\begin{array}{c}\text { Setor } \\
\text { Pu/Pr/ } \\
\text { ONG }\end{array}$ \\
\hline 1 & $\mathrm{~F}$ & Arquitetura & - & São Paulo & S-SVP & $\mathrm{Pu}$ \\
\hline 2 & M & $\begin{array}{l}\text { Ciências } \\
\text { Contábeis }\end{array}$ & - & São Paulo & $\mathrm{s}$ & $\mathrm{Pu}$ \\
\hline 3 & $\mathrm{~F}$ & $\begin{array}{l}\text { Engenharia } \\
\text { Química }\end{array}$ & - & São Paulo & $\mathrm{S}$ & $\mathrm{Pu}$ \\
\hline 4 & $M$ & Engenheiro Civil & - & São Paulo & $\mathrm{S}$ & $\mathrm{Pu}$ \\
\hline 5 & $M$ & Arquitetura & - & São Paulo & S - EMPLASA & $\mathrm{Pu}$ \\
\hline 6 & $F$ & Geografia & - & São Paulo & $\mathrm{S}$ & $\mathrm{Pu}$ \\
\hline 7 & $\mathrm{M}$ & Filosofia & - & São Paulo & $\mathrm{S}$ & $\mathrm{Pu}$ \\
\hline 8 & $\mathrm{~F}$ & Arquitetura & - & São Paulo & $\mathrm{S}$ & $\mathrm{Pu}$ \\
\hline 9 & $F$ & Geografia & - & São Paulo & S - CEPAM & $\mathrm{Pu}$ \\
\hline 10 & $\mathrm{M}$ & Engenharia Civil & - & São Paulo & $\mathrm{S}$ & $\mathrm{Pu}$ \\
\hline 11 & $\mathrm{M}$ & Direito & - & Barueri & $\mathrm{S}$ & $\mathrm{Pu}$ \\
\hline 12 & M & Ciências Sociais & - & Jundiaí & $\begin{array}{l}\text { S - Sec. } \\
\text { Saúde }\end{array}$ & $\mathrm{Pu}$ \\
\hline 13 & M & $\begin{array}{c}\text { Eng. } \\
\text { Cartográfica }\end{array}$ & - & São Paulo & $\mathrm{s}$ & $\mathrm{Pu}$ \\
\hline 14 & $M$ & Administração & - & São Paulo & $\mathrm{S}$ & $\mathrm{Pu}$ \\
\hline 15 & $M$ & Arquitetura & - & São Paulo & S - Sempla & $\mathrm{Pu}$ \\
\hline 16 & $M$ & Engenharia Civil & - & São Paulo & $\mathrm{N}-\mathrm{TCM}$ & $\mathrm{Pu}$ \\
\hline 17 & $\mathrm{~F}$ & Arquitetura & - & São Paulo & $\mathrm{S}$ & $\mathrm{Pu}$ \\
\hline 18 & $F$ & Arquitetura & - & São Paulo & N CET & $\mathrm{Pu}$ \\
\hline 19 & $\mathrm{~F}$ & Arquitetura & - & São Paulo & $\mathrm{S}$ & $\mathrm{Pu}$ \\
\hline 20 & $\mathrm{~F}$ & Biologia & - & São Paulo & $\mathrm{S}$ & $\mathrm{Pu}$ \\
\hline 21 & $\mathrm{~F}$ & Ed. Artística & - & São Paulo & $\begin{array}{c}\text { S - Dep. Patri. } \\
\text { Hstórico }\end{array}$ & $\mathrm{Pu}$ \\
\hline 22 & $\mathrm{~F}$ & Agronomia & - & São Paulo & $\mathrm{S}$ & $\mathrm{Pu}$ \\
\hline 23 & $F$ & Arquitetura & - & São Paulo & $\mathrm{S}$ & $\mathrm{Pu}$ \\
\hline 24 & M & $\begin{array}{l}\text { Engenharia } \\
\text { Elétrica }\end{array}$ & - & São Paulo & $\mathrm{s}$ & $\mathrm{Pu}$ \\
\hline 25 & $M$ & Engenharia Civil & - & São Paulo & $\mathrm{S}$ & $\mathrm{Pu}$ \\
\hline 26 & $F$ & Arquitetura & - & São Paulo & S -Sempla & $\mathrm{Pu}$ \\
\hline 27 & $F$ & Letras & - & São Paulo & $S$ & $\mathrm{Pu}$ \\
\hline 28 & $\mathrm{~F}$ & Jornalismo & - & São Paulo & $\mathrm{S}$ & $\mathrm{Pu}$ \\
\hline 29 & $\mathrm{~F}$ & $\begin{array}{c}\text { Eng. } \\
\text { Agronômica }\end{array}$ & - & São Paulo & $\mathrm{S}$ & $\mathrm{Pu}$ \\
\hline 30 & $M$ & Ciências Sociais & - & São Paulo & $\mathrm{S}$ & $\mathrm{Pu}$ \\
\hline 31 & M & $\begin{array}{l}\text { Ed. Artística, } \\
\text { Musica e Artes } \\
\text { Plásticas, } \\
\text { Pedagogia, } \\
\text { Administração }\end{array}$ & - & São Paulo & $\begin{array}{c}\text { S } \\
\text { Sec Educação }\end{array}$ & $\mathrm{Pu}$ \\
\hline
\end{tabular}

Legenda: M-masculino; F-feminino; S-sim; N-não; Pv-Privado; Pu-Público; ONG organização não governamental; CEGA- Curso de Especialização em Gestão Ambiental 


\section{CEGA-3 - Identificação dos Alunos}

\begin{tabular}{|c|c|c|c|c|c|c|}
\hline & $\begin{array}{l}\text { Gênero } \\
\text { M/F }\end{array}$ & Formação & $\begin{array}{c}\text { Ano de } \\
\text { conclusão/ } \\
\text { graduação }\end{array}$ & $\begin{array}{l}\text { Local de } \\
\text { atuação }\end{array}$ & $\begin{array}{l}\text { Trabalha na } \\
\text { área - S/N }\end{array}$ & $\begin{array}{c}\text { Setor } \\
\text { Pu/Pr/ } \\
\text { ONG }\end{array}$ \\
\hline 1 & $\mathrm{~F}$ & $\begin{array}{l}\text { Ciências } \\
\text { Contábeis }\end{array}$ & - & São Paulo & $\mathrm{S}$ & $\mathrm{Pu}$ \\
\hline 2 & $\mathrm{M}$ & Arquitetura & - & São Paulo & $\mathrm{N}$ & $\mathrm{Pu}$ \\
\hline 3 & $\mathrm{~F}$ & Enfermagem & - & $\begin{array}{c}\text { Taboão } \\
\text { da Serra }\end{array}$ & S - Sec.saúde & $\mathrm{Pu}$ \\
\hline 4 & M & $\begin{array}{l}\text { Arquitetura/Eng. } \\
\text { Segurança }\end{array}$ & - & São Paulo & $\mathrm{N}$ & $\mathrm{Pu}$ \\
\hline 5 & $\mathrm{~F}$ & Arquitetura & - & São Paulo & $\mathrm{N}$ & $\mathrm{Pu}$ \\
\hline 6 & $M$ & Arquitetura & - & São Paulo & $\mathrm{N}$ & $\mathrm{Pu}$ \\
\hline 7 & $\mathrm{~F}$ & $\begin{array}{l}\text { Ciências } \\
\text { Contábeis }\end{array}$ & - & São Paulo & $\mathrm{N}$ & $\mathrm{Pu}$ \\
\hline 8 & $\mathrm{~F}$ & Geologia & - & São Paulo & $\mathrm{S}$ & $\mathrm{Pu}$ \\
\hline 9 & $M$ & Geografia & - & São Paulo & S - Emplasa & $\mathrm{Pu}$ \\
\hline 10 & $\mathrm{M}$ & Arquitetura & - & São Paulo & $\mathrm{S}$ & $\mathrm{Pu}$ \\
\hline 11 & $\mathrm{M}$ & Ciências Sociais & - & São Paulo & $\mathrm{S}$ & $\mathrm{Pu}$ \\
\hline 12 & $\mathrm{~F}$ & Arquitetura & - & São Paulo & S - Sempla & $\mathrm{Pu}$ \\
\hline 13 & $\mathrm{M}$ & Letras & - & São Paulo & $\mathrm{S}$ & $\mathrm{Pu}$ \\
\hline 14 & $\mathrm{~F}$ & Arquitetura & - & São Paulo & $\mathrm{S}$ & $\mathrm{Pu}$ \\
\hline 15 & $\mathrm{~F}$ & Arquitetura & - & São Paulo & $\mathrm{N}$ & $\mathrm{Pu}$ \\
\hline 16 & $\mathrm{~F}$ & $\begin{array}{c}\text { Eng. } \\
\text { Agronômica }\end{array}$ & - & São Paulo & $\mathrm{N}$ & $\mathrm{Pu}$ \\
\hline 17 & $\mathrm{~F}$ & Arquitetura & - & São Paulo & $\mathrm{N}$ & $\mathrm{Pu}$ \\
\hline 18 & $\mathrm{~F}$ & Arquitetura & - & São Paulo & $\mathrm{S}$ & $\mathrm{Pu}$ \\
\hline 19 & $\mathrm{~F}$ & Letras/Direito & - & São Paulo & $\mathrm{S}$ & $\mathrm{Pu}$ \\
\hline 20 & $\mathrm{~F}$ & Arquitetura & - & São Paulo & $\mathrm{N}$ & $\mathrm{Pu}$ \\
\hline 21 & $\mathrm{~F}$ & Arquitetura & - & São Paulo & $\mathrm{N}$ & $\mathrm{Pu}$ \\
\hline 22 & $\mathrm{~F}$ & $\begin{array}{c}\text { Tecnólogo em } \\
\text { construção civil }\end{array}$ & - & São Paulo & $\mathrm{N}$ & $\mathrm{Pu}$ \\
\hline 23 & $M$ & Geologia & - & São Paulo & $\mathrm{S}$ & $\mathrm{Pu}$ \\
\hline 24 & $M$ & Geologia & - & São Paulo & $\mathrm{S}$ & $\mathrm{Pu}$ \\
\hline 25 & $\mathrm{~F}$ & Enfermagem & - & São Paulo & $\begin{array}{l}\text { S - Secr. } \\
\text { Saúde }\end{array}$ & $\mathrm{Pu}$ \\
\hline 26 & $\mathrm{~F}$ & $\begin{array}{c}\text { Ciências } \\
\text { Contábeis }\end{array}$ & - & São Paulo & $\mathrm{N}$ & $\mathrm{Pu}$ \\
\hline 27 & $\mathrm{M}$ & Administração & - & São Paulo & $\mathrm{S}$ & $\mathrm{Pu}$ \\
\hline 28 & $\mathrm{~F}$ & Serviço Social & - & São Paulo & $\mathrm{N}$ & $\mathrm{Pu}$ \\
\hline 29 & $\mathrm{~F}$ & Serviço Social & - & São Paulo & $\mathrm{S}$ & $\mathrm{Pu}$ \\
\hline 30 & $\mathrm{M}$ & Arquitetura & - & São Paulo & $\mathrm{N}$ & $\mathrm{Pu}$ \\
\hline 31 & $M$ & Arquitetura & - & São Paulo & $\mathrm{S}$ & $\mathrm{Pu}$ \\
\hline
\end{tabular}

Legenda: M-masculino; F-feminino; S-sim; N-não; Pv-Privado; Pu-Público; ONG organização não governamental; CEGA- Curso de Especialização em Gestão Ambiental 


\section{CEGA-4 - Identificação dos Alunos}

\begin{tabular}{|c|c|c|c|c|c|c|}
\hline & $\begin{array}{c}\text { Gênero } \\
\text { M/F }\end{array}$ & Formação & $\begin{array}{c}\text { Ano de } \\
\text { conclusão/ } \\
\text { graduação }\end{array}$ & $\begin{array}{l}\text { Local de } \\
\text { atuação }\end{array}$ & $\begin{array}{c}\text { Trabalha na } \\
\text { área - S/N }\end{array}$ & $\begin{array}{c}\text { Setor } \\
\text { Pu/Pr/ } \\
\text { ONG }\end{array}$ \\
\hline 1 & $\mathrm{M}$ & $\begin{array}{c}\text { Engenharia } \\
\text { Florestal }\end{array}$ & - & Jundiaí & $S$ & $\mathrm{Pu}$ \\
\hline 2 & $\mathrm{~F}$ & $\begin{array}{l}\text { Engenharia } \\
\text { Agronômica }\end{array}$ & - & Jundiaí & $\mathrm{N}$ & $\mathrm{Pu}$ \\
\hline 3 & $\mathrm{~F}$ & Serviço Social & - & Jundiaí & $\mathrm{N}$ & $\mathrm{Pu}$ \\
\hline 4 & $\mathrm{~F}$ & Direito & - & Jundiaí & $\mathrm{N}$ & $\mathrm{Pu}$ \\
\hline 5 & $M$ & Biologia & - & Jundiaí & $\mathrm{S}$ & $\mathrm{Pu}$ \\
\hline 6 & $M$ & Eng. Química & - & Jundiaí & $\mathrm{S}$ & $\mathrm{Pu}$ \\
\hline 7 & $\mathrm{~F}$ & Ciências Sociais & - & Jundiaí & $\mathrm{N}$ & $\mathrm{Pu}$ \\
\hline 8 & $M$ & Psicologia & - & Jundiaí & $\mathrm{N}$ & $\mathrm{Pu}$ \\
\hline 9 & $M$ & Eng. Civil & - & Jundiaí & $\mathrm{N}$ & $\mathrm{Pr}$ \\
\hline 10 & $\mathrm{M}$ & Eng. Civil & - & Jundiaí & $\mathrm{S}$ & $\mathrm{Pu}$ \\
\hline 11 & $M$ & Eng. Civil & - & Jundiaí & $\mathrm{S}$ & $\mathrm{Pu}$ \\
\hline 12 & $\mathrm{~F}$ & Arquitetura & - & Jundiaí & $\mathrm{S}$ & $\mathrm{Pu}$ \\
\hline 13 & M & $\begin{array}{c}\text { Eng. } \\
\text { Agronômica }\end{array}$ & - & Jundiaí & $\mathrm{s}$ & $\mathrm{Pu}$ \\
\hline 14 & $\mathrm{~F}$ & Administração & - & Jundiaí & $\mathrm{N}$ & $\mathrm{Pu}$ \\
\hline 15 & $\mathrm{~F}$ & Letras & - & Jundiaí & $\mathrm{S}$ & $\mathrm{Pu}$ \\
\hline 16 & $\mathrm{~F}$ & $\begin{array}{l}\text { Administração/ } \\
\text { Ciências da } \\
\text { Computação }\end{array}$ & - & Jundiaí & $\mathrm{N}$ & $\mathrm{Pu}$ \\
\hline 17 & $\mathrm{~F}$ & Biologia & - & Jundiaí & $\mathrm{S}$ & $\mathrm{Pu}$ \\
\hline 18 & $\mathrm{~F}$ & Serviço Social & - & Jundiaí & $\mathrm{N}$ & $\mathrm{Pu}$ \\
\hline 19 & $\mathrm{~F}$ & Serviço Social & - & Jundiaí & $\mathrm{N}$ & $\mathrm{Pu}$ \\
\hline 20 & $\mathrm{~F}$ & Geografia & - & São Paulo & $\mathrm{S}$ & $\mathrm{Pu}$ \\
\hline 21 & $\mathrm{~F}$ & Eng. Civil & - & Jundiaí & $\mathrm{N}$ & $\mathrm{Pu}$ \\
\hline 22 & $\mathrm{~F}$ & Arquitetura & - & Jundiaí & $\mathrm{N}$ & $\mathrm{Pr}$ \\
\hline 23 & $\mathrm{~F}$ & Letras & - & Jundiaí & $\mathrm{N}$ & $\mathrm{Pu}$ \\
\hline 24 & $\mathrm{~F}$ & - & - & Jundiaí & $S$ & $\mathrm{Pu}$ \\
\hline 25 & $\mathrm{M}$ & $\begin{array}{c}\text { Letras/ } \\
\text { Pedagogia }\end{array}$ & - & Jundiaí & $\mathrm{N}$ & $\mathrm{Pr}$ \\
\hline 26 & $M$ & Engenharia & - & Jundiaí & $S$ & $\mathrm{Pu}$ \\
\hline 27 & $\mathrm{~F}$ & Jornalismo & - & São Paulo & $\mathrm{S}$ & $\mathrm{Pu}$ \\
\hline 28 & $\mathrm{~F}$ & $\begin{array}{c}\text { Educação } \\
\text { Artística }\end{array}$ & - & Jundiaí & $\mathrm{N}$ & $\mathrm{Pu}$ \\
\hline 29 & $M$ & Eng. Civil & - & Jundiaí & $\mathrm{S}$ & $\mathrm{Pu}$ \\
\hline 30 & $M$ & Direito & - & Jundiaí & $S$ & $\mathrm{Pu}$ \\
\hline 31 & $F$ & História & - & Jundiaí & - & - \\
\hline
\end{tabular}

Legenda: M-masculino; F-feminino; S-sim; N-não; Pv-Privado; Pu-Público; ONG organização não governamental; CEGA- Curso de Especialização em Gestão Ambiental 


\section{CEGA-5 - Identificação dos Alunos}

\begin{tabular}{|c|c|c|c|c|c|c|}
\hline & $\begin{array}{l}\text { Gênero } \\
\text { M/F }\end{array}$ & Formação & $\begin{array}{c}\text { Ano de } \\
\text { conclusão/ } \\
\text { graduação }\end{array}$ & $\begin{array}{l}\text { Local de } \\
\text { atuação }\end{array}$ & $\begin{array}{c}\text { Trabalha na } \\
\text { Área - S/N }\end{array}$ & $\begin{array}{l}\text { Setor } \\
\text { Pu/Pr/ } \\
\text { ONG }\end{array}$ \\
\hline 1 & $\mathrm{~F}$ & Eng. Química & - & São Paulo & $\mathrm{S}$ & $\mathrm{Pu}$ \\
\hline 2 & $\mathrm{~F}$ & Med. Veterinária & - & São Paulo & $\mathrm{S}$ & $\mathrm{Pu}$ \\
\hline 3 & $\mathrm{~F}$ & $\begin{array}{c}\text { Eng. } \\
\text { Agronômica }\end{array}$ & - & São Paulo & $\mathrm{s}$ & $\mathrm{Pu}$ \\
\hline 4 & $\mathrm{~F}$ & Biologia & - & São Paulo & $\mathrm{S}$ & $\mathrm{Pu}$ \\
\hline 5 & $\mathrm{~F}$ & Arquitetura & - & São Paulo & $\mathrm{S}$ & $\mathrm{Pu}$ \\
\hline 6 & $M$ & Arquitetura & - & São Paulo & $S$ & $\mathrm{Pu}$ \\
\hline 7 & $\mathrm{~F}$ & Arquitetura & - & São Paulo & $\mathrm{S}$ & $\mathrm{Pu}$ \\
\hline 8 & M & $\begin{array}{l}\text { Química } \\
\text { Industrial }\end{array}$ & - & São Paulo & $\mathrm{s}$ & $\mathrm{Pu}$ \\
\hline 9 & $M$ & Eng. Civil & - & São Paulo & $\mathrm{S}$ & $\mathrm{Pu}$ \\
\hline 10 & $\mathrm{M}$ & Biologia & - & São Paulo & $\mathrm{S}$ & $\mathrm{Pu}$ \\
\hline 11 & M & $\begin{array}{c}\text { Eng. } \\
\text { Agronômica }\end{array}$ & - & São Paulo & $\mathrm{s}$ & $\mathrm{Pu}$ \\
\hline 12 & $M$ & Eng. Florestal & - & São Paulo & $S$ & $\mathrm{Pu}$ \\
\hline 13 & $F$ & Med. Veterinária & - & São Paulo & $\mathrm{S}$ & $\mathrm{Pu}$ \\
\hline 14 & $\mathrm{~F}$ & Serviço Social & - & São Paulo & $\mathrm{S}$ & $\mathrm{Pu}$ \\
\hline 15 & $\mathrm{~F}$ & Medicina & 1978 & São Paulo & $S$ & $\mathrm{Pu}$ \\
\hline 16 & $F$ & Pedagogia & - & São Paulo & $\mathrm{N}$ & $\mathrm{Pu}$ \\
\hline 17 & $\mathrm{~F}$ & Pedagogia & - & São Paulo & $\mathrm{N}$ & $\mathrm{Pu}$ \\
\hline 18 & $\mathrm{~F}$ & Geografia & - & São Paulo & $S$ & $\mathrm{Pu}$ \\
\hline 19 & $F$ & Serviço Social & - & São Paulo & $\mathrm{S}$ & $\mathrm{Pu}$ \\
\hline 20 & $\mathrm{~F}$ & $\begin{array}{c}\text { Eng. } \\
\text { Agronômica }\end{array}$ & - & São Paulo & $\mathrm{s}$ & $\mathrm{Pu}$ \\
\hline 21 & $M$ & Eng. Civil & - & São Paulo & $\mathrm{S}$ & $\mathrm{Pu}$ \\
\hline 22 & $\mathrm{~F}$ & - & 1995 & São Paulo & $\mathrm{S}$ & $\mathrm{Pu}$ \\
\hline 23 & $\mathrm{~F}$ & $\begin{array}{c}\text { Eng. } \\
\text { Agronômica }\end{array}$ & - & São Paulo & $\mathrm{S}$ & $\mathrm{Pu}$ \\
\hline 24 & $F$ & Biologia & - & São Paulo & $\mathrm{S}$ & $\mathrm{Pu}$ \\
\hline 25 & $\mathrm{~F}$ & $\begin{array}{l}\text { Ciências } \\
\text { Contábeis }\end{array}$ & - & São Paulo & $\mathrm{N}$ & $\mathrm{Pu}$ \\
\hline 26 & $M$ & Geologia & - & São Paulo & $\mathrm{S}$ & $\mathrm{Pu}$ \\
\hline 27 & M & $\begin{array}{l}\text { Ecologia } \\
\text { Biologia }\end{array}$ & - & São Paulo & $\mathrm{s}$ & $\mathrm{Pu}$ \\
\hline 28 & $M$ & Sociologia & - & São Paulo & $\mathrm{S}$ & $\mathrm{Pu}$ \\
\hline 29 & $\mathrm{~F}$ & Serviço Social & - & São Paulo & $\mathrm{S}$ & $\mathrm{Pu}$ \\
\hline
\end{tabular}

Legenda: M-masculino; F-feminino; S-sim; N-não; Pv-Privado; Pu-Público; ONG organização não governamental; CEGA- Curso de Especialização em Gestão Ambiental 


\section{CEGA-6 - Identificação dos Alunos}

\begin{tabular}{|c|c|c|c|c|c|c|}
\hline & $\begin{array}{c}\text { Gênero } \\
\text { M/F }\end{array}$ & Formação & $\begin{array}{c}\text { Ano de } \\
\text { conclusão/ } \\
\text { Graduação }\end{array}$ & $\begin{array}{c}\text { Local de } \\
\text { atuação }\end{array}$ & $\begin{array}{c}\text { Trabalha na } \\
\text { área - S/N }\end{array}$ & $\begin{array}{c}\text { Setor } \\
\text { Pu/Pr/ } \\
\text { ONG }\end{array}$ \\
\hline 1 & $\mathrm{~F}$ & Arquitetura & - & - & $\mathrm{N}$ & - \\
\hline 2 & $\mathrm{M}$ & $\begin{array}{c}\text { Engenharia } \\
\text { Química }\end{array}$ & - & - & $\mathrm{N}$ & - \\
\hline 3 & $\mathrm{~F}$ & Biologia & - & São Paulo & $\mathrm{S}$ & $\mathrm{Pr}$ \\
\hline 4 & $\mathrm{M}$ & $\begin{array}{c}\text { Medicina } \\
\text { Veterinária }\end{array}$ & - & Guarulhos & $\mathrm{S}$ & $\mathrm{Pu}$ \\
\hline 5 & $\mathrm{M}$ & Medicina & - & Campinas & $\mathrm{S}$ & $\mathrm{Pu}$ \\
\hline 6 & $\mathrm{M}$ & $\begin{array}{c}\text { Engenharia } \\
\text { Agronômica }\end{array}$ & - & Campinas & $\mathrm{S}$ & $\mathrm{Pu}$ \\
\hline 7 & $\mathrm{M}$ & Biologia & - & São Paulo & $\mathrm{S}$ & $\mathrm{Pu}$ \\
\hline 8 & $\mathrm{M}$ & Engenharia Civil & - & São Paulo & $\mathrm{N}$ & $\mathrm{Pr}$ \\
\hline 9 & $\mathrm{M}$ & Estudos Sociais & - & Guarulhos & $\mathrm{S}$ & $\mathrm{Pu}$ \\
\hline 10 & $\mathrm{~F}$ & $\begin{array}{c}\text { Engenharia } \\
\text { Química }\end{array}$ & - & São Paulo & $\mathrm{S}$ & $\mathrm{Pu}$ \\
\hline 11 & $\mathrm{M}$ & Medicina & - & São Paulo & $\mathrm{N}$ & $\mathrm{Pu}$ \\
\hline 12 & $\mathrm{~F}$ & Arquitetura & - & - & $\mathrm{N}$ & - \\
\hline 13 & $\mathrm{M}$ & $\begin{array}{c}\text { Engenharia } \\
\text { Agronômica }\end{array}$ & - & - & $\mathrm{N}$ & - \\
\hline 14 & $\mathrm{M}$ & Engenharia Civil & - & São Paulo & $\mathrm{S}$ & $\mathrm{Pr}$ \\
\hline 15 & $\mathrm{M}$ & Arquitetura & - & $\begin{array}{c}\text { Taboão } \\
\text { da Serra }\end{array}$ & $\mathrm{S}$ & $\mathrm{Pu}$ \\
\hline 16 & $\mathrm{~F}$ & Arquitetura & - & São Paulo & $\mathrm{S}$ & $\mathrm{Pu}$ \\
\hline 17 & $\mathrm{M}$ & - & São Paulo & $\mathrm{N}$ & $\mathrm{Pr}$ \\
\hline 18 & $\mathrm{~F}$ & Arquitetura & - & Jacareí & $\mathrm{N}$ & $\mathrm{Pr}$ \\
\hline 19 & $\mathrm{M}$ & $\begin{array}{c}\text { Ciências } \\
\text { Contabeis }\end{array}$ & - & São Paulo & $\mathrm{S}$ & $\mathrm{Pu}$ \\
\hline 20 & $\mathrm{M}$ & Ciências Sociais & - & - & $\mathrm{N}$ & - \\
\hline 21 & $\mathrm{M}$ & Educação Física & - & São Paulo & $\mathrm{S}$ & $\mathrm{Pu}$ \\
\hline 22 & $\mathrm{M}$ & Engenharia Civil & - & São Paulo & $\mathrm{N}$ & $\mathrm{Pr}$ \\
\hline 23 & $\mathrm{M}$ & $\begin{array}{c}\text { Matemática } \\
\text { Pedagogia }\end{array}$ & - & Guarulhos & $\mathrm{S}$ & $\mathrm{Pu}$ \\
\hline 24 & $\mathrm{~F}$ & Arquitetura & - & São Paulo & $\mathrm{N}$ & $\mathrm{Pu}$ \\
\hline 25 & $\mathrm{M}$ & Pedagogia & - & Osasco & $\mathrm{N}$ & $\mathrm{Pu}$ \\
\hline 26 & $\mathrm{~F}$ & Ciências Sociais & - & São Paulo & $\mathrm{S}$ & $\mathrm{ONG}$ \\
\hline & & & & & \\
\hline 1982 & & & & & & \\
\hline
\end{tabular}

Legenda: M-masculino; F-feminino; S-sim; N-não; Pv-Privado; Pu-Público; ONG organização não governamental; CEGA- Curso de Especialização em Gestão Ambiental 


\section{CEGA-7 - Identificação dos Alunos}

\begin{tabular}{|c|c|c|c|c|c|c|}
\hline & $\begin{array}{c}\text { Gênero } \\
\text { M/F }\end{array}$ & Formação & $\begin{array}{c}\text { Ano de } \\
\text { conclusão/ } \\
\text { graduação }\end{array}$ & $\begin{array}{l}\text { Local de } \\
\text { atuação }\end{array}$ & \begin{tabular}{|c|} 
Trabalha \\
na área - \\
S/N \\
\end{tabular} & $\begin{array}{l}\text { Setor } \\
\text { Pu/Pr/ } \\
\text { ONG }\end{array}$ \\
\hline 1 & M & $\begin{array}{l}\text { Engenharia } \\
\text { Mecânica }\end{array}$ & - & São Paulo & $\mathrm{S}$ & $\operatorname{Pr}$ \\
\hline 2 & $\mathrm{~F}$ & Arquitetura & - & São Paulo & $\mathrm{S}$ & $\mathrm{Pu}$ \\
\hline 3 & $\mathrm{M}$ & Administração & - & São Paulo & $\mathrm{N}$ & $\mathrm{Pr}$ \\
\hline 4 & $\mathrm{M}$ & Biologia & - & São Paulo & $\mathrm{S}$ & $\mathrm{Pr}$ \\
\hline 5 & $\mathrm{M}$ & Arquitetura & - & São Paulo & $\mathrm{N}$ & $\mathrm{Pu}$ \\
\hline 6 & $\mathrm{M}$ & $\begin{array}{c}\text { Engenheiro } \\
\text { Florestal }\end{array}$ & - & São Paulo & - & - \\
\hline 7 & $\mathrm{~F}$ & Biologia & - & - & $\mathrm{N}$ & $\mathrm{Pr}$ \\
\hline 8 & $\mathrm{M}$ & Biologia & - & São Paulo & - & - \\
\hline 9 & $\mathrm{~F}$ & Agronomia & - & - & - & - \\
\hline 10 & $\mathrm{~F}$ & Ciências Sociais & - & São Paulo & $\mathrm{S}$ & $\mathrm{Pu}$ \\
\hline 11 & M & $\begin{array}{l}\text { Tecnologia da } \\
\text { Construção Civil }\end{array}$ & - & São Paulo & $S$ & $\mathrm{Pu}$ \\
\hline 12 & $\mathrm{~F}$ & - & 1996 & São Paulo & $\mathrm{N}$ & $\mathrm{Pr}$ \\
\hline 13 & M & $\begin{array}{l}\text { Engenharia } \\
\text { Agronômica }\end{array}$ & - & São Paulo & $\mathrm{S}$ & $\mathrm{Pr}$ \\
\hline 14 & $\mathrm{~F}$ & Agronomia & - & São Paulo & $\mathrm{S}$ & $\mathrm{Pr}$ \\
\hline 15 & $\mathrm{M}$ & Geólogo & 1995 & São Paulo & $\mathrm{S}$ & $\mathrm{Pr}$ \\
\hline 16 & $\mathrm{~F}$ & Engenharia Química & - & São Paulo & $\mathrm{N}$ & $\mathrm{Pr}$ \\
\hline 17 & M & $\begin{array}{l}\text { Engenheiro } \\
\text { Sanitarista }\end{array}$ & 1992 & Diadema & $\mathrm{S}$ & $\mathrm{Pu}$ \\
\hline 18 & $\mathrm{~F}$ & Serviço Social & - & São Paulo & $\mathrm{N}$ & $\mathrm{Pu}$ \\
\hline 19 & $\mathrm{~F}$ & Biologia & - & - & - & - \\
\hline 20 & M & $\begin{array}{l}\text { Engenharia } \\
\text { Agronômica }\end{array}$ & - & - & - & - \\
\hline 21 & $\mathrm{~F}$ & Direito & - & - & - & - \\
\hline 22 & M & $\begin{array}{l}\text { Engenharia de } \\
\text { Minas }\end{array}$ & - & São Paulo & $\mathrm{s}$ & $\mathrm{Pr}$ \\
\hline 23 & $\mathrm{~F}$ & Arquiteta & - & - & - & - \\
\hline 24 & $\mathrm{~F}$ & Farmácia & - & São Paulo & $\mathrm{S}$ & $\mathrm{Pr}$ \\
\hline 25 & $\mathrm{~F}$ & Veterinária & - & São Paulo & $\mathrm{N}$ & $\mathrm{Pr}$ \\
\hline 26 & $\mathrm{M}$ & Biologia & - & Salesópolis & $\mathrm{S}$ & $\mathrm{Pr}$ \\
\hline 27 & M & Engenharia Elétrica & - & Guarulhos & $\mathrm{N}$ & $\mathrm{Pr}$ \\
\hline 28 & $M$ & Biologia & - & - & - & - \\
\hline 29 & M & $\begin{array}{c}\text { Engenharia de } \\
\text { Minas }\end{array}$ & - & São Paulo & $\mathrm{s}$ & $\mathrm{Pr}$ \\
\hline 30 & $\mathrm{~F}$ & Química & - & São Paulo & $\mathrm{S}$ & $\mathrm{Pr}$ \\
\hline 31 & $\mathrm{~F}$ & $\begin{array}{c}\text { Administração de } \\
\text { Empresas }\end{array}$ & - & São Paulo & $\mathrm{N}$ & $\mathrm{Pu}$ \\
\hline 32 & $\mathrm{~F}$ & Biologia & - & $\begin{array}{l}\text { Mogi das } \\
\text { Cruzes }\end{array}$ & $\mathrm{S}$ & ONG \\
\hline 33 & $\mathrm{~F}$ & Biologia & - & São Paulo & $\mathrm{N}$ & $\mathrm{Pu}$ \\
\hline 34 & $\mathrm{~F}$ & Direito & - & Embú & $\mathrm{N}$ & $\mathrm{Pr}$ \\
\hline
\end{tabular}

Legenda: M-masculino; F-feminino; S-sim; N-não; Pv-Privado; Pu-Público; ONG organização não governamental; CEGA- Curso de Especialização em Gestão Ambiental 


\section{CEGA-8 - Identificação dos Alunos}

\begin{tabular}{|c|c|c|c|c|c|c|}
\hline & $\begin{array}{c}\text { Gênero } \\
\text { M/F }\end{array}$ & Formação & $\begin{array}{c}\text { Ano de } \\
\text { conclusão/ } \\
\text { graduação }\end{array}$ & $\begin{array}{l}\text { Local de } \\
\text { atuação }\end{array}$ & $\begin{array}{c}\text { Trabalha } \\
\text { na área - } \\
\text { S/N }\end{array}$ & $\begin{array}{l}\text { Setor } \\
\text { Pu/Pr/ } \\
\text { ONG } \\
\end{array}$ \\
\hline 1 & $\mathrm{M}$ & Biologia & 1994 & São Paulo & $\mathrm{S}$ & $\mathrm{Pu}$ \\
\hline 2 & M & Engenharia Civil & 1991 & São Paulo & $\mathrm{N}$ & $\mathrm{Pr}$ \\
\hline 3 & $\mathrm{M}$ & Engenharia Eletrica & 1992 & São Paulo & $\mathrm{S}$ & $\mathrm{Pu}$ \\
\hline 4 & $M$ & Engenharia & 1990 & São Paulo & $\mathrm{S}$ & $\mathrm{Pr}$ \\
\hline 5 & M & Direito & 1999 & $\begin{array}{l}\text { Ribeirão } \\
\text { Pires }\end{array}$ & $\mathrm{S}$ & $\mathrm{Pu}$ \\
\hline 6 & $\mathrm{~F}$ & Química & 1983 & São Paulo & $\mathrm{N}$ & $\mathrm{Pu}$ \\
\hline 7 & M & $\begin{array}{l}\text { Engenharia } \\
\text { Metalurgica }\end{array}$ & 1984 & São Paulo & $\mathrm{S}$ & $\mathrm{Pu}$ \\
\hline 8 & $\mathrm{~F}$ & Engenharia Civil & 1995 & São Paulo & $\mathrm{S}$ & $\mathrm{Pr}$ \\
\hline 9 & M & $\begin{array}{l}\text { Administração de } \\
\text { Empresas }\end{array}$ & 1998 & aulo & $\mathrm{S}$ & $\mathrm{Pr}$ \\
\hline 10 & $\mathrm{~F}$ & Biologia & 1990 & Guarulhos & $\mathrm{S}$ & $\mathrm{Pr}$ \\
\hline 11 & $\mathrm{M}$ & Engenheiro & 1979 & Lins & $\mathrm{N}$ & $\mathrm{Pr}$ \\
\hline 12 & M & Engenharia Sanitária & 1984 & São Paulo & $\mathrm{S}$ & $\mathrm{Pu}$ \\
\hline 13 & $\mathrm{M}$ & Engenharia Civil & 1992 & São Paulo & $\mathrm{N}$ & $\mathrm{Pr}$ \\
\hline 14 & $M$ & Direito & 1982 & São Paulo & $\mathrm{S}$ & $\mathrm{Pu}$ \\
\hline 15 & $\mathrm{M}$ & Geologia & 1996 & São Paulo & $\mathrm{S}$ & $\mathrm{Pu}$ \\
\hline 16 & $\mathrm{~F}$ & Direito & 1972 & São Paulo & $\mathrm{N}$ & $\mathrm{Pu}$ \\
\hline 17 & M & Engenharia Civil & 1993 & São Paulo & $\mathrm{N}$ & $\mathrm{Pu}$ \\
\hline 18 & $M$ & Ecologia & 1996 & São Paulo & $\mathrm{S}$ & $\mathrm{Pu}$ \\
\hline 19 & M & $\begin{array}{l}\text { Engenharia } \\
\text { Mecânica }\end{array}$ & 1979 & Cubatão & $\mathrm{S}$ & $\mathrm{Pr}$ \\
\hline 20 & M & Engenharia Florestal & 1994 & Embu & $\mathrm{S}$ & $\mathrm{Pu}$ \\
\hline 21 & $M$ & Contabilidade & 1998 & São Paulo & $\mathrm{N}$ & $\mathrm{Pr}$ \\
\hline 22 & $\bar{M}$ & Medicina Veterinária & 1989 & São Paulo & $\mathrm{N}$ & $\mathrm{Pr}$ \\
\hline 23 & M & Direito & 1997 & São Paulo & $\mathrm{S}$ & $\mathrm{Pr}$ \\
\hline 24 & $\mathrm{M}$ & Engenheiro Civil & 1979 & São Paulo & $\mathrm{S}$ & $\mathrm{Pu}$ \\
\hline 25 & $\mathrm{~F}$ & Biologia & 1988 & São Paulo & $\mathrm{N}$ & $\mathrm{Pr}$ \\
\hline 26 & $\mathrm{~F}$ & $\begin{array}{c}\text { Direito-Geografia-C. } \\
\text { Sociais }\end{array}$ & 1989 & São Paulo & $\mathrm{N}$ & $\mathrm{Pr}$ \\
\hline 27 & $\mathrm{~F}$ & Geografia & 1998 & São Paulo & $\mathrm{N}$ & $\mathrm{Pr}$ \\
\hline 28 & $\mathrm{M}$ & Engenharia & 1984 & São Paulo & $\mathrm{S}$ & $\mathrm{Pu}$ \\
\hline 29 & $\mathrm{~F}$ & Direito & 1996 & São Paulo & $\mathrm{N}$ & $\mathrm{Pr}$ \\
\hline 30 & $M$ & Arquitetura & 1980 & Sorocaba & $\mathrm{N}$ & $\mathrm{Pr}$ \\
\hline 31 & $M$ & Biologia & 1996 & São Paulo & $\mathrm{S}$ & ONG \\
\hline 32 & $\mathrm{M}$ & Engenharia Civil & 1997 & São Paulo & $\mathrm{N}$ & $\mathrm{Pr}$ \\
\hline 33 & $M$ & Direito & 1990 & São Paulo & $\mathrm{N}$ & $\mathrm{Pr}$ \\
\hline 34 & $\mathrm{~F}$ & Biologia & 1984 & São Paulo & $\mathrm{N}$ & $\mathrm{Pu}$ \\
\hline 35 & $\mathrm{M}$ & - & 1988 & São Paulo & $\mathrm{N}$ & $\mathrm{Pr}$ \\
\hline 36 & $\mathrm{~F}$ & Geografia & 1998 & São Paulo & $\mathrm{N}$ & $\mathrm{Pr}$ \\
\hline 37 & $\mathrm{~F}$ & Direito & 1997 & - & - & 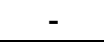 \\
\hline 38 & $M$ & - & 1989 & São Paulo & $\mathrm{S}$ & $\mathrm{Pr}$ \\
\hline
\end{tabular}

Legenda: M-masculino; F-feminino; S-sim; N-não; Pv-Privado; Pu-Público; ONG organização não governamental; CEGA- Curso de Especialização em Gestão Ambiental 


\section{CEGA-9 - Identificação dos Alunos}

\begin{tabular}{|c|c|c|c|c|c|c|}
\hline & $\begin{array}{l}\text { Gênero } \\
\text { M/F }\end{array}$ & Formação & $\begin{array}{c}\text { Ano de } \\
\text { conclusão/ } \\
\text { graduação }\end{array}$ & $\begin{array}{l}\text { Local de } \\
\text { atuação }\end{array}$ & $\begin{array}{c}\text { Trabalha na } \\
\text { área - S/N }\end{array}$ & $\begin{array}{c}\text { Setor } \\
\text { Pu/Pr/ } \\
\text { ONG }\end{array}$ \\
\hline 1 & $\mathrm{~F}$ & Biologia & 1996 & São Paulo & $\mathrm{S}$ & $\mathrm{Pr}$ \\
\hline 2 & $\mathrm{~F}$ & Geografia & 1998 & São Paulo & $\mathrm{S}$ & $\mathrm{Pr}$ \\
\hline 3 & $\mathrm{~F}$ & Biologia & 1997 & São Paulo & $\mathrm{S}$ & $\mathrm{Pr}$ \\
\hline 4 & M & \begin{tabular}{|c} 
Tecnólogo Eng. \\
Operação
\end{tabular} & 1983 & São Paulo & $\mathrm{S}$ & $\mathrm{Pu}$ \\
\hline 5 & M & Pedagogia & 1996 & São Paulo & $\mathrm{S}$ & $\mathrm{Pu}$ \\
\hline 6 & M & Direito & 1985 & São Paulo & $\mathrm{S}$ & $\mathrm{Pr}$ \\
\hline 7 & $\mathrm{~F}$ & Biologia & 1996 & São Paulo & $\mathrm{S}$ & $\mathrm{Pu}$ \\
\hline 8 & $\mathrm{M}$ & Economia & 1993 & São Paulo & $\mathrm{S}$ & $\mathrm{Pu}$ \\
\hline 9 & $\mathrm{~F}$ & Arquitetura & $! 997$ & São Paulo & $\mathrm{N}$ & $\mathrm{Pr}$ \\
\hline 10 & $\mathrm{~F}$ & Ciências Sociais & 1993 & $\begin{array}{l}\text { Santo } \\
\text { André }\end{array}$ & S & $\mathrm{Pu}$ \\
\hline 11 & $\mathrm{~F}$ & Arquitetura & 1971 & São Paulo & $\mathrm{S}$ & $\mathrm{Pu}$ \\
\hline 12 & $F$ & Biologia & 1997 & - & - & - \\
\hline 13 & $\mathrm{~F}$ & Arquitetura & 1998 & - & - & - \\
\hline 14 & M & Biologia & 1996 & Osasco & $\mathrm{S}$ & $\mathrm{Pr}$ \\
\hline 15 & $M$ & Eng. Civil & 1985 & - & - & - \\
\hline 16 & M & Geologia & 1988 & São Paulo & $\mathrm{S}$ & $\mathrm{Pu}$ \\
\hline 17 & M & Eng. Civil & 1985 & $\begin{array}{l}\text { São B. do } \\
\text { Campo }\end{array}$ & $\mathrm{S}$ & $\mathrm{Pu}$ \\
\hline 18 & $\mathrm{M}$ & Administração & 1999 & - & - & - \\
\hline 19 & $M$ & Administração & 1999 & São Paulo & $\mathrm{S}$ & $\mathrm{Pr}$ \\
\hline 20 & $\mathrm{~F}$ & Eng. Química & 1996 & São Paulo & $\mathrm{S}$ & $\mathrm{Pr}$ \\
\hline 21 & $\mathrm{~F}$ & Eng. Sanitarista & 1997 & São Paulo & $\mathrm{S}$ & $\mathrm{Pr}$ \\
\hline 22 & $\mathrm{M}$ & Biólogo & 1989 & Colômbia & - & - \\
\hline 23 & $\mathrm{~F}$ & Direito & 1998 & São Paulo & $\mathrm{S}$ & $\mathrm{Pr}$ \\
\hline 24 & $\mathrm{~F}$ & Eng. Química & 1993 & São Paulo & $\mathrm{S}$ & $\mathrm{Pr}$ \\
\hline 25 & M & Eng. Civil & 1986 & $\begin{array}{c}\text { São } \\
\text { Lourenço } \\
\text { da Serra }\end{array}$ & $\mathrm{S}$ & $\mathrm{Pu}$ \\
\hline 26 & $\mathrm{~F}$ & Letras & 1994 & São Paulo & $\mathrm{S}$ & $\mathrm{Pu}$ \\
\hline 27 & $\mathrm{~F}$ & $\begin{array}{c}\text { Ciências do } \\
\text { Trabalho }\end{array}$ & 1982 & São Paulo & $\mathrm{S}$ & $\mathrm{Pr}$ \\
\hline 28 & M & Eng. Industrial & 1972 & São Paulo & $\mathrm{N}$ & $\mathrm{Pu}$ \\
\hline 29 & $\mathrm{~F}$ & $\begin{array}{c}\text { Comunicação } \\
\text { Social }\end{array}$ & 1995 & São Paulo & $\mathrm{N}$ & $\mathrm{Pr}$ \\
\hline 30 & $F$ & Biologia & 1997 & São Paulo & $\mathrm{S}$ & $\mathrm{Pr}$ \\
\hline 31 & $\mathrm{~F}$ & Arquitetura & 1982 & São Paulo & $\mathrm{S}$ & $\mathrm{Pu}$ \\
\hline 32 & $M$ & Eng. Químico & 1999 & ch & - & $z_{1}$ \\
\hline 33 & $\mathrm{M}$ & Eng. Mecânico & 1984 & São Paulo & $\mathrm{N}$ & $\mathrm{Pr}$ \\
\hline 34 & $M$ & Eng. Mecânica & 1990 & São Paulo & $\mathrm{N}$ & $\mathrm{Pr}$ \\
\hline
\end{tabular}

Legenda: M-masculino; F-feminino; S-sim; N-não; Pv-Privado; Pu-Público; ONG organização não governamental; CEGA- Curso de Especialização em Gestão Ambiental 
CEGA-10 - Identificação dos Alunos

\begin{tabular}{|c|c|c|c|c|c|c|}
\hline & $\begin{array}{c}\text { Gênero } \\
\text { M/F }\end{array}$ & Formação & $\begin{array}{c}\text { Ano de } \\
\text { conclusão/ } \\
\text { Graduação }\end{array}$ & $\begin{array}{l}\text { Local de } \\
\text { atuação }\end{array}$ & $\begin{array}{c}\text { Trabalha na } \\
\text { área - S/N }\end{array}$ & $\begin{array}{l}\text { Setor } \\
\text { Pu/Prl } \\
\text { ONG }\end{array}$ \\
\hline 1 & $\mathrm{M}$ & Biologia & 1998 & Sto André & $\mathrm{S}$ & $\mathrm{Pr}$ \\
\hline 2 & $\mathrm{M}$ & Administração & 1985 & Campinas & - & - \\
\hline 3 & $M$ & Engenharia & 1983 & Santos & $\mathrm{S}$ & $\mathrm{Pr}$ \\
\hline 4 & $M$ & Engenharia & 1986 & São Paulo & $\mathrm{N}$ & $\mathrm{Pr}$ \\
\hline 5 & $\mathrm{~F}$ & $\begin{array}{l}\text { Engenharia de } \\
\text { Materiais }\end{array}$ & 1997 & São Paulo & $\mathrm{N}$ & $\operatorname{Pr}$ \\
\hline 6 & $\mathrm{~F}$ & Geografia & 1991 & São Paulo & $\mathrm{S}$ & $\mathrm{Pu}$ \\
\hline 7 & M & $\begin{array}{l}\text { Tecnólogo } \\
\text { Sanitarista }\end{array}$ & 1998 & Salto & $\mathrm{N}$ & $\operatorname{Pr}$ \\
\hline 8 & M & $\begin{array}{l}\text { Engenharia } \\
\text { Mecânica }\end{array}$ & 1975 & São Paulo & $\mathrm{S}$ & $\mathrm{Pu}$ \\
\hline 9 & $M$ & Biologia & 1999 & São Paulo & $\mathrm{N}$ & $\mathrm{Pu}$ \\
\hline 10 & $M$ & Direito & 1974 & São Paulo & $\mathrm{N}$ & $\mathrm{Pr}$ \\
\hline 11 & M & Economia & 1989 & Manaus & $\mathrm{N}$ & $\mathrm{Pr}$ \\
\hline 12 & $M$ & Biologia & 1989 & São Paulo & $\mathrm{N}$ & $\mathrm{Pu}$ \\
\hline 13 & $\mathrm{~F}$ & Agronomia & 1991 & Santos & $\mathrm{N}$ & $\mathrm{Pu}$ \\
\hline 14 & $\mathrm{~F}$ & Arquitetura & 1980 & São Paulo & $\mathrm{S}$ & $\mathrm{Pu}$ \\
\hline 15 & $\mathrm{~F}$ & Engenharia & 1985 & $\begin{array}{l}\text { Sto. } \\
\text { André }\end{array}$ & S & $\mathrm{Pu}$ \\
\hline 16 & $M$ & Direito & 1983 & São Paulo & $\mathrm{S}$ & $\mathrm{Pu}$ \\
\hline 17 & M & Química & 1986 & São Paulo & $\mathrm{N}$ & $\mathrm{Pr}$ \\
\hline 18 & $\mathrm{M}$ & Biologia & 1981 & Sumaré & $\mathrm{S}$ & $\mathrm{Pr}$ \\
\hline 19 & $\mathrm{M}$ & Biologia & 1987 & São Paulo & $\mathrm{N}$ & $\mathrm{Pr}$ \\
\hline 20 & M & Engenharia & 1997 & São Paulo & $\mathrm{N}$ & $\mathrm{Pr}$ \\
\hline 21 & $\mathrm{~F}$ & Biologia & 1979 & São Paulo & $\mathrm{S}$ & $\mathrm{Pu}$ \\
\hline 22 & M & $\begin{array}{l}\text { Engenharia } \\
\text { Agronômica }\end{array}$ & 1985 & São Paulo & $\mathrm{S}$ & ONG \\
\hline 23 & $\mathrm{~F}$ & Geologia & 1972 & São Paulo & $\mathrm{N}$ & $\mathrm{Pr}$ \\
\hline 24 & $\mathrm{~F}$ & Biologia & 1984 & São Paulo & $\mathrm{N}$ & $\mathrm{Pu}$ \\
\hline 25 & $\mathrm{~F}$ & Serviço Social & 1983 & $\begin{array}{l}\text { Sto. } \\
\text { André }\end{array}$ & $N$ & $\mathrm{Pu}$ \\
\hline 26 & M & $\begin{array}{l}\text { Engenharia } \\
\text { Agronômica }\end{array}$ & 1994 & São Paulo & $\mathrm{s}$ & $\mathrm{Pu}$ \\
\hline 27 & $\mathrm{~F}$ & $\begin{array}{l}\text { Engenharia } \\
\text { Agronômica }\end{array}$ & 1997 & São Paulo & $\mathrm{N}$ & $\operatorname{Pr}$ \\
\hline 28 & $\mathrm{~F}$ & Economia & 1998 & S.C. Sul & $\mathrm{S}$ & ONG \\
\hline 29 & $\mathrm{~F}$ & Artes Plásticas & 1981 & São Paulo & $\mathrm{S}$ & $\mathrm{Pu}$ \\
\hline 30 & $\mathrm{M}$ & Direito & 1986 & Osasco & $\mathrm{S}$ & $\mathrm{Pr}$ \\
\hline 31 & $\mathrm{~F}$ & Engenharia Civil & 1984 & São Paulo & $\mathrm{S}$ & $\mathrm{Pu}$ \\
\hline 32 & $\mathrm{~F}$ & Biologia & 1998 & São Paulo & $\mathrm{N}$ & ONG \\
\hline 33 & $\mathrm{~F}$ & Arquitetura & 1978 & São Paulo & $\mathrm{S}$ & $\mathrm{Pu}$ \\
\hline 34 & $\mathrm{~F}$ & Biologia & 1991 & São Paulo & $\mathrm{S}$ & $\mathrm{Pu}$ \\
\hline
\end{tabular}

Legenda: M-masculino; F-feminino; S-sim; N-não; Pv-Privado; Pu-Público; ONG organização não governamental; CEGA- Curso de Especialização em Gestão Ambiental 
CEGA-11 - Identificação dos Alunos

\begin{tabular}{|c|c|c|c|c|c|c|}
\hline & $\begin{array}{c}\text { Gênero } \\
\text { M/F }\end{array}$ & Formação & $\begin{array}{c}\text { Ano de } \\
\text { conclusão/ } \\
\text { graduação }\end{array}$ & $\begin{array}{l}\text { Local de } \\
\text { atuação }\end{array}$ & $\begin{array}{c}\text { Trabalha na } \\
\text { área - S/N }\end{array}$ & $\begin{array}{l}\text { Setor } \\
\text { Pu/Pr/ } \\
\text { ONG }\end{array}$ \\
\hline 1 & $\mathrm{~F}$ & Direito & 1990 & Bauru & $\mathrm{S}$ & $\mathrm{Pu}$ \\
\hline 2 & M & Eng. Civil & - & $\begin{array}{l}\text { Ribeirão } \\
\text { Preto }\end{array}$ & $\mathrm{N}$ & $\mathrm{Pu}$ \\
\hline 3 & $M$ & Eng. Civil & 1985 & Botucatu & $\mathrm{N}$ & $\mathrm{Pr}$ \\
\hline 4 & $\mathrm{M}$ & Eng. Agrônoma & 1977 & Bauru & $\mathrm{S}$ & $\mathrm{Pu}$ \\
\hline 5 & $\mathrm{M}$ & Eng. Civil & - & Lins & $\mathrm{S}$ & $\mathrm{Pr}$ \\
\hline 6 & M & Eng. Química & 1989 & Bauru & $\mathrm{S}$ & $\mathrm{Pu}$ \\
\hline 7 & $\mathrm{~F}$ & Desenho Ind. & - & Bauru & $\mathrm{S}$ & $\mathrm{Pu}$ \\
\hline 8 & M & Eng. Civil & 1985 & Bauru & $\mathrm{N}$ & $\mathrm{Pr}$ \\
\hline 9 & $\mathrm{~F}$ & Eng. Civil & 1985 & Bauru & $\mathrm{N}$ & $\mathrm{Pr}$ \\
\hline 10 & $\mathrm{M}$ & Eng. Civil & 1978 & Bauru & $\mathrm{S}$ & $\mathrm{Pu}$ \\
\hline 11 & $\mathrm{M}$ & Eng. Agron. & 1977 & Bauru & $\mathrm{S}$ & $\mathrm{Pu}$ \\
\hline 12 & $\mathrm{~F}$ & $\begin{array}{l}\text { Farmácia e } \\
\text { Bioquímica }\end{array}$ & 1986 & Rio Claro & $\mathrm{N}$ & $\mathrm{Pu}$ \\
\hline 13 & $\mathrm{~F}$ & Química Indu. & 1982 & Bauru & $\mathrm{N}$ & $\mathrm{Pr}$ \\
\hline 14 & M & $\begin{array}{c}\text { Process. de } \\
\text { Dados }\end{array}$ & 1993 & Bauru & $\mathrm{S}$ & $\mathrm{Pu}$ \\
\hline 15 & $\mathrm{~F}$ & Biologia & 1999 & Jaú & $\mathrm{N}$ & $\mathrm{Pu}$ \\
\hline 16 & $\mathrm{~F}$ & Farmácia & 1988 & Bauru & $\mathrm{S}$ & $\mathrm{Pu}$ \\
\hline 17 & M & Eng. Agronômica & 1982 & Jaú & $\mathrm{N}$ & $\mathrm{Pr}$ \\
\hline 18 & $\mathrm{M}$ & Eng. Civil & 1997 & Bauru & $\mathrm{N}$ & $\mathrm{Pr}$ \\
\hline 19 & M & Eng. Florestal & - & Jaú & $\mathrm{N}$ & $\mathrm{Pu}$ \\
\hline 20 & $M$ & Matemática & 1997 & Bauru & $\mathrm{S}$ & $\mathrm{Pu}$ \\
\hline 21 & $\mathrm{M}$ & Eng. Florestal & - & Agudos & $\mathrm{S}$ & $\mathrm{Pr}$ \\
\hline 22 & M & Arquitetura & - & Cafelân. & $\mathrm{N}$ & $\mathrm{Pr}$ \\
\hline 23 & M & Eng. Químico & - & $\begin{array}{c}\text { Lençois } \\
\text { Pta }\end{array}$ & $\mathrm{S}$ & $\operatorname{Pr}$ \\
\hline 24 & M & Eng. Agornômica & - & $\begin{array}{c}\text { Lençois } \\
\text { Pta }\end{array}$ & $\mathrm{N}$ & $\mathrm{Pr}$ \\
\hline 25 & $\mathrm{~F}$ & Desenho Ind. & - & Bauru & $\mathrm{S}$ & $\mathrm{Pu}$ \\
\hline 26 & $\mathrm{M}$ & Agronomia & 1986 & Bauru & $\mathrm{N}$ & $\mathrm{Pu}$ \\
\hline 27 & $\mathrm{M}$ & Administração & - & Bauru & $\mathrm{N}$ & $\mathrm{Pr}$ \\
\hline 28 & $\mathrm{~F}$ & Eng. Civil & 1992 & Bariri & $\mathrm{S}$ & $\mathrm{Pu}$ \\
\hline 29 & $\mathrm{~F}$ & Eng. Civil & 1981 & Bauru & $\mathrm{S}$ & $\mathrm{Pu}$ \\
\hline 30 & $\mathrm{M}$ & Eng. Agronômica & 1975 & Ibitinga & $\mathrm{N}$ & $\mathrm{Pr}$ \\
\hline 31 & $\mathrm{M}$ & Desenho Ind. & 1993 & Bauru & $\mathrm{S}$ & $\mathrm{Pu}$ \\
\hline 32 & M & Administração & - & $\begin{array}{c}\text { Lençóis } \\
\text { Pta }\end{array}$ & $\mathrm{s}$ & $\operatorname{Pr}$ \\
\hline 33 & M & Eng. Mecânica & 1986 & Votoran. & $\mathrm{S}$ & $\mathrm{Pr}$ \\
\hline 34 & $\mathrm{~F}$ & Serviço Social & 1982 & Bauru & $\mathrm{S}$ & $\mathrm{Pu}$ \\
\hline 35 & $\mathrm{~F}$ & Direito & 1980 & Campinas & $\mathrm{N}$ & $\mathrm{Pr}$ \\
\hline 36 & M & Eng. Química & - & Jaú & $\mathrm{N}$ & $\mathrm{Pr}$ \\
\hline 37 & $\mathrm{M}$ & Eng. Civil & - & Bauru & $\mathrm{N}$ & $\mathrm{Pr}$ \\
\hline 38 & $\mathrm{M}$ & Arquitetura & 1991 & Bauru & $\mathrm{N}$ & $\mathrm{Pu}$ \\
\hline
\end{tabular}

Legenda: M-masculino; F-feminino; S-sim; N-não; PV-Privado; Pu-Público; ONG organização não governamental; CEGA- Curso de Especialização em Gestão Ambiental 


\begin{tabular}{|c|c|c|c|c|c|c|}
\hline & $\begin{array}{c}\text { Gênero } \\
\text { M/F }\end{array}$ & Formação & $\begin{array}{c}\text { Ano de } \\
\text { conclusão/ } \\
\text { Graduação }\end{array}$ & $\begin{array}{l}\text { Local de } \\
\text { atuação }\end{array}$ & $\begin{array}{l}\text { Trabalha } \\
\text { na área - } \\
\text { S/N }\end{array}$ & $\begin{array}{c}\text { Setor } \\
\text { Pu/Pr/ } \\
\text { ONG }\end{array}$ \\
\hline 1 & $F$ & Arquitetura & - & São Paulo & $\mathrm{N}$ & $\mathrm{Pr}$ \\
\hline 2 & $\mathrm{~F}$ & Eng. Mecânica & 1999 & São Paulo & $\mathrm{N}$ & $\mathrm{Pr}$ \\
\hline 3 & $\mathrm{~F}$ & Biologia & 1994 & Campinas & $\mathrm{S}$ & $\mathrm{Pr}$ \\
\hline 4 & $\mathrm{M}$ & Engenharia & 1982 & São Paulo & $\mathrm{S}$ & $\mathrm{Pr}$ \\
\hline 5 & $\mathrm{~F}$ & Marketing & 1998 & São Paulo & - & - \\
\hline 6 & $M$ & Eng. Florestal & 1997 & São Paulo & $\mathrm{S}$ & $\mathrm{Pu}$ \\
\hline 7 & $\mathrm{~F}$ & Eng. Química & 1999 & São Paulo & $\mathrm{N}$ & $\mathrm{Pu}$ \\
\hline 8 & $M$ & Biologia & 1998 & São Paulo & $\mathrm{S}$ & $\mathrm{Pr}$ \\
\hline 9 & $\mathrm{M}$ & Geografia & 1999 & São Paulo & $\mathrm{N}$ & - \\
\hline 10 & $\mathrm{~F}$ & Economia & 1989 & S. B Campo & $\mathrm{N}$ & $\mathrm{Pu}$ \\
\hline 11 & $\mathrm{~F}$ & Biologia & 1976 & Guarulhos & $\mathrm{N}$ & $\mathrm{Pu}$ \\
\hline 12 & $F$ & Engenharia & 1995 & - & - & - \\
\hline 13 & $\mathrm{~F}$ & Química & 1994 & - & $\mathrm{N}$ & - \\
\hline 14 & $\mathrm{M}$ & Arquitetura & 1993 & São Paulo & $\mathrm{N}$ & $\mathrm{Pr}$ \\
\hline 15 & $\mathrm{M}$ & Eng. Agrônoma & 1995 & São Paulo & $\mathrm{N}$ & $\mathrm{Pr}$ \\
\hline 16 & $\mathrm{M}$ & Química & 1997 & S. C. do Sul & $\mathrm{N}$ & $\mathrm{Pr}$ \\
\hline 17 & $\mathrm{M}$ & Biologia & 1997 & - & - & - \\
\hline 18 & $\mathrm{~F}$ & Administração & 1991 & - & - & - \\
\hline 19 & $\mathrm{~F}$ & Geologia & 1996 & São Paulo & $\mathrm{S}$ & $\mathrm{Pr}$ \\
\hline 20 & $F$ & Biologia & 1995 & $\begin{array}{c}\text { Taboão da } \\
\text { Serra }\end{array}$ & $\mathrm{N}$ & $\mathrm{Pu}$ \\
\hline 21 & $\mathrm{~F}$ & Biologia & 1980 & São Paulo & $\mathrm{N}$ & $\mathrm{Pu}$ \\
\hline 22 & $\mathrm{M}$ & Eng. Civil & 1974 & São Paulo & $\mathrm{N}$ & $\mathrm{Pr}$ \\
\hline 23 & $M$ & Eng. Civil & 1990 & Sorocaba & S & $\mathrm{pr}$ \\
\hline
\end{tabular}

Legenda: M-masculino; F-feminino; S-sim; N-não; Pv-Privado; Pu-Público; ONG organização não governamental; CEGA- Curso de Especialização em Gestão Ambiental 
CEGA-13 - Identificação dos Alunos

\begin{tabular}{|c|c|c|c|c|c|c|}
\hline & $\begin{array}{l}\text { Gênero } \\
\text { M/F }\end{array}$ & Formação & $\begin{array}{c}\text { Ano de } \\
\text { conclusão/ } \\
\text { Graduação }\end{array}$ & $\begin{array}{l}\text { Local de } \\
\text { atuação }\end{array}$ & $\begin{array}{c}\text { Trabalha na } \\
\text { área - S/N }\end{array}$ & $\begin{array}{l}\text { Setor } \\
\text { Pu/Pr/ } \\
\text { ONG }\end{array}$ \\
\hline 1 & $\mathrm{~F}$ & Arquiteta & 1984 & Guarulhos & $\mathrm{S}$ & $\mathrm{Pr}$ \\
\hline 2 & M & Economia & 1994 & $\begin{array}{l}\text { Santo } \\
\text { André }\end{array}$ & S & $\mathrm{Pu}$ \\
\hline 3 & $\mathrm{M}$ & Química & 1992 & Guarulhos & $\mathrm{S}$ & $\mathrm{Pr}$ \\
\hline 4 & M & Administração & 1987 & São Paulo & $\mathrm{S}$ & $\mathrm{Pr}$ \\
\hline 5 & M & $\begin{array}{l}\text { Processamento } \\
\text { de Dados }\end{array}$ & 1997 & $\begin{array}{l}\text { Vargem } \\
\text { Grande } \\
\text { Pta }\end{array}$ & $S$ & $\mathrm{Pr}$ \\
\hline 6 & $\mathrm{~F}$ & - & - & - & - & - \\
\hline 7 & $\mathrm{~F}$ & Veterinária & 1993 & Guarulhos & $\mathrm{S}$ & $\mathrm{Pu}$ \\
\hline 8 & $\mathrm{~F}$ & Eng. Civil & 1990 & São Paulo & $\mathrm{S}$ & $\mathrm{Pu}$ \\
\hline 9 & $\mathrm{~F}$ & Química & 1986 & São Paulo & $\mathrm{S}$ & $\mathrm{Pu}$ \\
\hline 10 & $M$ & Eng. Civil & 1991 & São Paulo & $\mathrm{S}$ & $\mathrm{Pu}$ \\
\hline 11 & $M$ & Eng. Mecânica & 1991 & $\begin{array}{l}\text { Campo } \\
\text { Limpo }\end{array}$ & $\mathrm{N}$ & $\operatorname{Pr}$ \\
\hline 12 & M & $\begin{array}{l}\text { Eng. De } \\
\text { Produção }\end{array}$ & 1984 & $\begin{array}{c}\text { Sta. } \\
\text { Bárbara } \\
\text { d"oeste }\end{array}$ & $S$ & $\mathrm{Pu}$ \\
\hline 13 & M & $\begin{array}{l}\text { Eng. De } \\
\text { Produção }\end{array}$ & 1994 & São Paulo & $\mathrm{S}$ & ONG \\
\hline 14 & $\mathrm{M}$ & Administração & 1984 & São Paulo & $\mathrm{S}$ & $\mathrm{Pu}$ \\
\hline 15 & M & $\begin{array}{l}\text { Engenharia } \\
\text { Naval }\end{array}$ & 1974 & São Paulo & $\mathrm{s}$ & $\operatorname{Pr}$ \\
\hline 16 & $M$ & Eng. Agrônoma & 1978 & $\begin{array}{c}\text { Sta. } \\
\text { Bárbara } \\
\text { d'Oeste }\end{array}$ & $S$ & $\mathrm{Pu}$ \\
\hline 17 & $\mathrm{~F}$ & Geografia & 1977 & São Paulo & $\mathrm{S}$ & $\mathrm{Pu}$ \\
\hline 18 & $\mathrm{M}$ & Eng. Civil & 1991 & São Paulo & $\mathrm{S}$ & $\mathrm{Pu}$ \\
\hline 19 & $\mathrm{~F}$ & Administração & 1996 & São Paulo & $\mathrm{S}$ & $\mathrm{Pr}$ \\
\hline 20 & $\mathrm{~F}$ & Eng. Civil & 1992 & São Paulo & $\mathrm{S}$ & $\mathrm{Pu}$ \\
\hline 21 & $M$ & Biologia & 2000 & - & - & - \\
\hline 22 & $M$ & Eng. Civil & 1996 & São Paulo & $\mathrm{S}$ & $\mathrm{Pu}$ \\
\hline 23 & $M$ & Biologia & 2000 & São Paulo & $\mathrm{S}$ & $\mathrm{Pu}$ \\
\hline 24 & $\mathrm{~F}$ & Geografia & 1990 & São Paulo & $\mathrm{S}$ & $\mathrm{Pu}$ \\
\hline 25 & $\mathrm{~F}$ & Sociologia & 2000 & São Paulo & $\mathrm{S}$ & ONG \\
\hline 26 & $M$ & Direito & 2000 & São Paulo & $\mathrm{N}$ & $\mathrm{Pr}$ \\
\hline 27 & M & $\begin{array}{c}\text { Eng. } \\
\text { Metalúrgica }\end{array}$ & 1989 & São Paulo & $\mathrm{s}$ & $\mathrm{Pu}$ \\
\hline 28 & $\mathrm{M}$ & Administração & 1998 & Guarulhos & $\mathrm{N}$ & $\mathrm{Pr}$ \\
\hline
\end{tabular}

Legenda: M-masculino; F-feminino; S-sim; N-não; Pv-Privado; Pu-Público; ONG organização não governamental; CEGA- Curso de Especialização em Gestão Ambiental 


\section{ANEXO 7}

\section{OPÇÕES TEMÁTICAS ADOTADAS NAS MONOGRAFIAS}

(CEGA 1 - CEGA 13) 


\section{CEGA-1}

- Transporte Urbano: Alternativas Tecnológicas para a região metropolitana de São Paulo.

- O Processo de Urbanização e o Programa de Corredores de Ônibus e Terminais de Integração do Município de São Paulo.

- A Gestão de Áreas Degradadas Para Fins Habitacionais

- Habitação Social: Apenas Uma Questão de Baixa Renda?

- Uso e Ocupação de Fundos de Vale.

- Uso e ocupação de fundos de vale: insumos para o reconhecimento de unidades ambientais homogêneas.

\section{CEGA-2}

- Equacionamento e solução de áreas sujeitas a inundação.

- Reorganização urbana de uma área central com produção de habitações de interesse social.

- Intervenção em áreas residenciais de baixa renda - resgate da qualidade ambiental urbana.

- Poluição do ar na região metropolitana de São Paulo veículos pesados - óleo diesel.

- Revisão da legislação de proteção aos mananciais de interesse da região metropolitana da grande São Paulo.

- Melhoria da qualidade do ar na região metropolitana de São Paulo - veículos álcool e gasolina.

- Vila Itororó: intervenção em áreas de baixa renda. 


\section{CEGA-3}

- Programa de gestão ambiental para o bairro de água fria no município de Cubatão - SP.

- Recursos hídricos e suas novas formas de gestão.

- Modelo de gestão em áreas de proteção e preservação ambiental - áreas de proteção aos mananciais.

- O rodízio de veículos na região metropolitana de São Paulo: suas implicações ambientais e eficácia.

- O transporte de cargas perigosas no âmbito da região metropolitana de São Paulo: o papel do anel rodoviário e outras alternativas de enfrentamento destes riscos ambientais.

- Novas formas de apropriação do verde nos empreendimentos econômicos e imobiliários: sua revalorização sob os pontos de vista econômicos, social e ambiental.

- A questão do manejo e gestão de resíduos de serviços de saúde na região metropolitana de São Paulo.

\section{CEGA-4}

- Transporte de cargas perigosas na região de Jundiaí.

- Jundiaí: cidade saudável.

- A questão dos resíduos sólidos no município de Jundiaí.

- Política Municipal de Meio Ambiente.

- Novas formas de apropriação do verde nos empreendimentos econômicos e imobiliários: a sua revalorização sob os pontos de vista econômico, social e ambiental.

- Recursos hídricos: levantamento do potencial para abastecimento urbano, ainda não utilizado no município de Jundiaí. 


\section{CEGA-5}

- Novas formas de apropriação do verde nos empreendimentos econômicos e imobiliários: a sua revalorização sob os pontos de vista econômico, social e ambiental.

- A distribuição do espaço urbano e o meio ambiente - um estudo de caso.

- Caracterização das normas tecno-legislativas para minimização dos riscos ambientais relativos a transportes de produtos perigosos na RMSP.

- A gestão dos recursos hídricos dos instrumentos de mobilização da sociedade. Reservatório Billings, um estudo de caso.

- Fontes móveis de poluição do ar: estudo na RMSP.

- Geografia dos agravos à saúde coletiva originados por um meio ambiente alterado pela ação antropogênica no município de São Paulo - História natural das ecoonoses e a gestão ambiental.

- A questão do manejo de resíduos na RMSP: a articulação inter-municipal para a solução do problema e suas repercursões ambientais.

- Gestão e manejo de áreas de preservação de mananciais na região sul do município de São Paulo.

\section{CEGA-6}

- Instrumentos de avaliação de riscos à saúde como subsídio à gestão integrada de recursos hídricos.

- Unidades de Conservação.

- Educação ambiental como instrumento na Gestão Ambiental: aspectos comunicacionais.

- O ecoturismo como estratégias para conservação do patrimônio natural. 


\section{CEGA-7}

- A Educação Ambiental e sua Aplicação como Instrumento de Gestão.

- A Educação Ambiental como Instrumento Público de Gestão Ambiental em Cananéia.

- Resíduos Sólidos e o Meio Ambiente: o Caso de Embu das Artes.

- Áreas de Proteção aos Mananciais Gerenciamento de Resíduos Sólidos em Serviços de Saúde.

- Gerenciamento de Áreas a de Proteção e Preservação Ambiental.

- Habitação e Meio Ambiente.

- A Questão da Reciclagem na Sociedade Urbana.

- Reuso de Águas Residuárias na Indústria - um Estudo de Caso.

\section{CEGA-8}

- Gerenciamento de Recursos Hídricos na Região Metropolitana de São Paulo.

- Abastecimento de Água - Mananciais.

- Drenagem Urbana.

- Gerenciamento da Questão Habitacional.

- Gerenciamento de Resíduos Sólidos: Tratamento e Disposição.

- Águas Residuárias - Industrial.

- Transportes de Cargas.

- Espaços Públicos e Áreas Verdes.

- Transporte Público. 


\section{CEGA-9}

- Tratamento e Disposição de Resíduos Sólidos Urbanos Aspectos Legais da Limpeza Urbana no Município de São Paulo.

- Estado de Degradação dos Mananciais - Região Metropolitana de São Paulo no Contexto do Processo da Urbanização.

- Lixão de Ilha Bela: Estudo de Caso. O envolvimento de Técnicos, Poder Público e Comunidade Como Proposta de Melhoria da Qualidade Ambiental e Turística.

- Participação Comunitária na Gestão Pública - SEMASA Serviço Municipal de Saneamento Ambiental de Santo André.

- A Drenagem Urbana da Cidade de Santos e seus Reflexos.

- Educação Ambiental como Instrumento da Gestão Ambiental Empresarial.

- Águas Residuárias Industriais na Cidade de Santo André.

- Estratégias de Gestão Ambiental: Estudo de Caso APA Municipal do Capivarí Monos.

- Urbanização de Favelas.

- Empresas de Gestão e Educação Ambiental

- Pneus, Geração, Destinação e Possíveis Reaproveitamentos.

\section{CEGA-10}

- Gerenciamento Integrado dos Resíduos Sólidos Urbanos no Estado de São Paulo a partir da Década de 90.

- Viabilidade Econômica nas Áreas de Proteção de Mananciais no Estado de São Paulo.

- Uso e Ocupação do Solo Urbano no Estado de São Paulo.

- Gerenciamento Participativo.

- Resíduos Industriais.

- Identificação de Aspectos Ambientais nas Indústrias Automobilísticas - Estudo de Caso Volkswagen/São Carlos

- Normas de Qualidade Ambiental que Influenciam o Setor de Mineração Voltado para a Construção Civil, no Estado de São Paulo.

- Recursos Hídricos.

- Toxicologia como Ferramenta Básica da Autogestão nas Industrias do Setor Petrolífero do Estado de São Paulo. 


\section{CEGA-11}

- Avaliação do Custo/Benefício do Processo de Incineração do Resíduo de Serviço de Saúde (RSS) de Bauru e Região.

- Reaproveitamento de Pneus Usados: Alternativas de Sustentabilidade no Brasil.

- Resíduos e Subprodutos da Indústria Sucro Alcooleira e sua Utilização na Compostagem como Substituto do Fertilizante na Adubação de Cana de Açúcar.

- Poluição do Ar: o Impacto da Fabricação de Baterias e Bauru.

- Avaliação do Processo de Resíduos Sólidos Urbanos - RSU, na Cidade de Jaú.

- Recomposição Florestal com Essências Nativas em Áreas Degradadas do Município de lacanga.

- Estudo de Viabilidade Técnica de Tratamento de Esgoto Sanitário em duas Comunidades Delimitadas.

- Incineração de Resíduos Sólidos Urbanos - RSU do Município de Bauru com Geração de Energia Elétrica.

- Estudo da Tarifa de Água nos Diversos Segmentos do Município de Bauru.

\section{CEGA-12}

- A Coleta Seletiva na Região do Vale do Paraíba do Sul.

- Estudo da Importância da Arborização Urbana como Mitigadora dos Impactos Ambientais em um bairro de São Paulo

- Energia Eólica

- Sistema de Gestão Ambiental - Como, e o porquê da sua implantação

- Reuso de Água Industrial

- Gerenciamento Integrado dos Resíduos Sólidos do Município de Santo André 
- Gestão de bacias hidrográficas - poluição difusa.

- A coleta de resíduos sólidos para reciclagem: Uma política alternativa de desenvolvimento sustentável ou um destino politicamente correto da sociedade do desperdício e do descartável?

- Uso do lodo de esgoto doméstico na agricultura.

- Energia alternativas.

- Abordagem legal e impactos dos resíduos perigosos sobre o meio ambiente.

- Gestão ambiental e de recursos hídricos: aspectos legais institucionais na união, no Estado de são Paulo e no município de Jundiaí.

- Avaliação do passivo ambiental resultante da implantação de aterros sanitários localizados em zona urbana de municípios de pequeno e médio porte.

- Reuso de Águas residuárias na Indústria - um estudo de Caso. 